\title{
A Arte dos “Quadrinhos” e o Literário \\ A contribuição do diálogo entre o Verbal e o Visual para a reprodução e inovação dos modelos clássicos da cultura
}

Tese de Doutorado apresentada ao Departamento de Letras Clássicas e Vernáculas da Faculdade de Filosofia, Letras e Ciências Humanas da Universidade de São Paulo. Área dos Estudos Comparados de Literaturas de Língua Portuguesa. Orientadora: Prof. ${ }^{a}$ Dr. $^{a}$ Nelly Novaes Coelho. 


\section{A Arte dos “Quadrinhos” e o Literário}

A contribuição do diálogo entre o Verbal e o Visual para a reprodução e inovação dos modelos clássicos da cultura

Tese de Doutorado apresentada ao Departamento de Letras Clássicas e Vernáculas da Faculdade de Filosofia, Letras e Ciências Humanas da Universidade de São Paulo. Área dos Estudos Comparados de Literaturas de Língua Portuguesa. Orientadora: Prof. ${ }^{a}$ Dr. ${ }^{a}$ Nelly Novaes Coelho.

Dezembro de 2008.

BANCA EXAMINADORA

Dr ${ }^{\mathrm{a}}$ MARIA ZILDA DA CUNHA

Universidade de São Paulo

Dr $^{0}$ JOSÉ NICOLAU GREGORIN FILHO

Universidade de São Paulo

Dra IDMÉA SEMEGHINI SIQUEIRA

Universidade de São Paulo

Dr $^{0}$ JOSÉ MARIA RODRIGUES FILHO

Universidade Mogi das Cruzes 
Alfredo Rodrigues de Oliveira, in memorian

Pai, amigo e mestre por toda vida.

O "Sempre Presente" 


\section{AGRADECIMENTOS}

A meu pai, minha mãe, minhas irmãs e sobrinhas que tanto enriquecem a minha história.

À Universidade de São Paulo, por possibilitar o desenvolvimento dessa Tese.

À prof. ${ }^{a}$ Dr. ${ }^{a}$ Nelly Novaes Coelho, pelo valioso auxílio na orientação desse trabalho, permitindo novas reflexões e inspirações e, acima de tudo, por acreditar e me impulsionar para a continuidade de minha caminhada.

Aos Professores Dr. ${ }^{a}$ Maria Zilda da Cunha e Dr. ${ }^{0}$ José Nicolau Gregorin Filho pela participação nas minhas bancas de Qualificação e Defesa, e pela contribuição precisa em momentos decisivos da confecção desse estudo.

Aos professores Dr. ${ }^{a}$ Idméa Semeghini e Dr. ${ }^{o}$ José Maria Rodrigues por participarem da minha banca de Defesa e aos demais docentes que me auxiliaram durante a jornada acadêmica: Dr. a Maria Lúcia Góes, Dr. ${ }^{a}$ Maria dos Prazeres, Dr. ${ }^{a}$ Cláudia Dornbusch, Dr..$^{\text {a }}$ Selma Meireles, Dr. ${ }^{\circ}$ Ismail Xavier e Dr. ${ }^{a}$ Daisy Piccinini, dentre outros.

Aos teóricos, professores e autores que trabalham ou trabalharam com quadrinhos e cujas contribuições foram de vital importância para a compreensão da arte seqüencial: Moacy Cirne, Luiz Cagnin, Álvaro de Moya, Waldomiro Vergueiro, Flávio Calazans, Will Eisner, Scott McCloud, etc.

À Lourdes pelo importante auxílio, à Ivete Irene pelo grande apoio, e a todos aqueles que mesmo não citados me auxiliaram de alguma forma, seja fornecendo material, informação ou incentivo; minha gratidão. 


\section{RESUMO}

A interação entre diferentes linguagens e meios artísticos é uma das marcas presente no processo de comunicação humana, sobretudo hoje em dia. Um dos aspectos que se destaca nessa interação é a constante revisitação de obras que são re-elaboradas em diferentes suportes comunicativos. É o que ocorre quando temos o diálogo entre os quadrinhos e a literatura, artes que trabalham com a narratividade e que trazem em si peculiaridades que as definem como importantes meios de veiculação e propagação de idéias, valores e ideologias. Nesse estudo procuramos abordar a relação entre os dois meios artísticos destacando se tal diálogo propicia uma reprodução ou questionamento das tradições culturais, atualizando-as (ou não) a partir de sua transposição de uma arte para outra. A partir de teorias que versam sobre quadrinhos, intertextualidade, dialogismo, história da arte e da literatura e outras, traçamos um painel das diversas relações que se estabelecem entre obras criadas nos quadrinhos a partir do material literário, e que se revelam por meio de uma gradação em que temos desde obras que remetem diretamente ao texto clássico literário até aquelas que procuram fazer dos elementos oriundos da literatura um mote para o desenvolvimento de novas produções em quadrinhos. Também num movimento contrário, procuramos mostrar como os quadrinhos fornecem material para a criação de obras na literatura e como sua linguagem múltipla pode atuar em conjunto com o texto literário para a construção de obras mistas.

Palavras-chave: quadrinhos, literatura, linguagem, narrativas, dialogismo. 


\begin{abstract}
The interaction between different languages and artistic circles is one of the main issues in the process of human communication, especially today. One thing that stands out is that the constant interaction revisiting of works that are re-elaborated in various communication media. This is what happens when there is a dialogue between comics and literature, both arts which work with narrative and are filled with peculiarities that define them as important means of transmitting and spreading ideas, values and ideologies. In this study we tried to address the relationship between those two media arts, highlighting the questions concerning whether this dialogue provides a repetition or a questioning of cultural traditions, updating them (or not) from this translation of one art to another. Based on theories that deal with comics, intertexture, dialogism, history of art and literature and others, we draw a panel of the diverse relationships established between works created in comics from literary material, which reveal themselves by means of a gradation that goes from works that refer directly to the classic literary text to those who attempt to make the elements of literature a means for the development of new productions in comics. Also in an opposite movement, we try to show how comics provide material for the creation of works in literature and its varied language can co-act with the literary text for the construction of mixed works.
\end{abstract}

Keywords: Comics. Literature. Languages. Narratives. Dialogism. 
INTRODUÇÃ

1. O VERBAL E O VISUAL: CONTEXTO HISTÓRICO....................................16

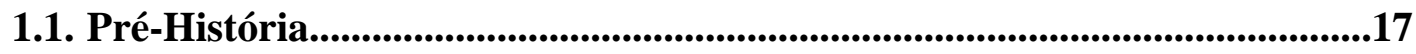

1.2. Surgimento da linguagem escrita.........................................................19

1.3. Letras e desenhos nas sociedades.........................................................22

1.4. Os quadrinhos e o encontro entre o verbal e o visual..................................26

2. A CONSTRUÇÃO NARRATIVA E SEUS CÓDIGOS......................................35

2.10 código narrativo..............................................................................37

2.2 Literatura: arte de contar estórias...........................................................42

2.3 HQs e as múltiplas linguagens......................................................................45

2.3.1 A leitura dos intervalos.................................................................47

2.3.2 Personagens e falas...............................................................................51

2.3.3 Narração em movimento....................................................................55

3. QUADRINHOS E LITERATURA: RELAÇÕES DIALÓGICAS.....................61

3.1. Transposições culturais: absorção e transformação...................................66

3.2. Da literatura para os quadrinhos.......................................................................73

3.2.1. Mantendo o texto-base......................................................................74

a) A Moreninha, um gancho para a literatura......................................76

b) Gaetaninho - crônica em quadrinhos............................................88

3.2.2 Inserção de novas dimensões narrativas..............................................97

a) Os Lusíadas: uma aventura intergaláctica......................................98 
b) Branca de Neve num jogo de montar. 107

3.2.3 Diálogo para novas obras. 117

a) Fábulas e fadas na mira do humor..................................................118

b) Shakespeare no mundo dos sonhos............................................131

3.2.4 Interferências e aproximações

3.3 Outras formas de interação

3.3.1 Das HQs para os livros

a) A desconstrução e a renovação do herói .148

b) Transpondo linguagens: uma leitura fiel. .155

3.3.2 Quadrinhos e literatura atuando em conjunto

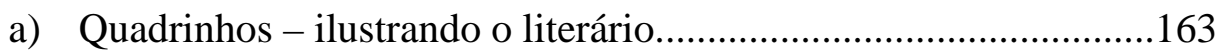

b) HQ e literatura: complementaridade narrativa.. 169

3.3.3 Intercruzamentos narrativos .177

BIBLIOGRAFIA. 


\section{INTRODUÇÃO}

“... Alguns preferem a literatura; outros, os quadrinhos. Nós preferimos os dois. Em alguns momentos, a literatura nos diz mais, ou muito mais; em outros, o bom quadrinho nos é mais significativo. Aqueles que só preferem a literatura (e o cinema) deixam de fora uma parte do saber cultural; aqueles que só preferem os quadrinhos perdem a possibilidade de se enriquecerem culturalmente."

Moacy Cirne

A necessidade de expressar ou de tornar realidade comunicável aos outros, suas experiências vividas, levou o Homem, desde a origem dos tempos, a inventar as mais variadas formas comunicativas. Essa necessidade de comunicação se confirma, através dos milênios, pelos registros deixados nas paredes das cavernas paleolíticas, e chegam aos nossos tempos, com os complexos processos da cultura cibernética. O diálogo entre as diversas formas de expressão artística tem sido, por sua vez, uma das importantes modalidades de comunicação inventadas pelos homens para elaborar as mais variadas narrativas, produzindo abstrações e sentidos dos mais diversos, demonstrando que, ao longo dos tempos, as obras não só estão em constante interação entre si, mas também com o mundo que as cerca, trazendo à tona influências intra e extra textuais.

Um aspecto importante da inter-relação entre as formas culturais é a constante revisitação de obras que são re-elaboradas em diferentes suportes comunicativos. É o caso das adaptações e outros diálogos, em que uma determinada criação artística é 
representada em diferentes meios, estando sujeita aos mecanismos próprios de elaboração daquele suporte. A revisitação de temas, personagens, etc., criados no passado, demonstra que a essência dos valores presentes nas representações culturais de ontem continuam vivos, pois dizem respeito à natureza humana. É bom lembrar que as obras continuamente revisitadas ao longo dos tempos trazem em si algo de "eterno", que as torna atemporais: “[...] toda grande obra [...] que venceu o Tempo e continua ‘falando’ ao interesse de cada nova geração, atende a outros 'motivos', [...] decorrentes de uma verdade humana geral” (COELHO, 1981, p.23).

Dentre os meios expressivos que revisitam e realizam diferentes formas de diálogo com obras produzidas em outros suportes, está a história em quadrinhos (HQ). Arte narrativa por natureza, o quadrinho traz em si grande potencial comunicativo, apresentando uma união própria entre as linguagens verbal e não-verbal. Com a literatura, arte que também trabalha com a narratividade, o quadrinho tem estabelecido uma ampla interação, em que as linguagens e enredos se interseccionam para o desenvolvimento de várias obras. Como leitora dos dois meios foi possível verificar que ambos apresentam recursos que, se bem aproveitados, podem enriquecer e possibilitar diferentes formas de comunicação, permitindo novos “olhares” sobre a sociedade e a existência humana.

Apesar da ampla popularidade dos "quadrinhos" como entretenimento temos poucas reflexões teóricas sobre seus processos de criação que nos permitam compreender como se dá o diálogo quadrinhos-literatura na prática: quais as possibilidades de união e intersecção entre os suportes? Qual a contribuição de tal interação para a produção 
cultural do nosso tempo? Que relações existiriam entre esse tipo de arte visual-verbal e as experiências da vida humana? A escolha do nosso tema resulta, pois, da necessidade de se construir um embasamento teórico que nos auxilie a entender o processo de construção narrativa, resultado do diálogo texto-ilustração, embasamento que será de grande importância para o estudo acadêmico dessa popular e cada vez mais sofisticada e complexa forma de arte e suas relações com as manifestações culturais próprias do mundo em que vivemos atualmente.

O objetivo desse estudo é, portanto, procurar identificar qual a contribuição das HQs, e mais especificamente, de seu diálogo com o literário, no fazer cultural da contemporaneidade, sobretudo no que diz respeito à reprodução ou o questionamento de formas e valores oriundos da tradição cultural. É importante verificar se esse diálogo propicia de fato um questionamento dos modelos clássicos (literários e dos quadrinhos) propondo assim novas formas de fazer e receber tais modelos.

Tendo como fio condutor a construção do enredo feita a partir da organização dos elementos estruturais da narrativa (sobretudo nos quadrinhos que apresentam recursos estéticos próprios, principalmente na relação entre as linguagens verbal e não-verbal), procuraremos identificar nas obras em destaque aspectos que denotem a reprodução ou o questionamento dos modelos e da tradição cultural (a relação com os cânones, a inserção do lúdico, a função pedagógica, etc.) e sua possível contribuição para o mundo atual. 
Para a área de Estudos Comparados de Literatura de Língua Portuguesa, particularmente, esse trabalho se mostra de extrema importância devido à escassa produção teórica voltada para estudos sobre a história em quadrinhos de língua portuguesa, principalmente na sua relação com o material literário, e com outras formas de interação e comunicação narrativas. A história em quadrinhos traz em sua cultura, cânones que têm servido de matrizes para gerar outros. Por outro lado, ela dialoga com cânones produzidos em outras manifestações artísticas. É uma arte que apresenta uma confluência de linguagens e elementos culturais, revelando, por vezes, dominações ideológicas que deixam suas marcas na produção cultural nacional. Daí a importância de incluir seu estudo na esfera das considerações teóricas em Língua Portuguesa, que necessita ampliar seu olhar para englobar as diversas formas de expressão e comunicação do nosso tempo, na medida em que novas ferramentas e manifestações estéticas passam a integrar a maneira como os indivíduos interagem com a cultura, e mais especificamente, com o material literário.

O corpus da pesquisa se compõe, principalmente, de obras em quadrinhos produzidas em língua portuguesa que estabelecem diálogo com o material literário. Também destacaremos algumas obras da literatura que apresentam diferentes relações com as HQs. Para que o estudo possa abarcar outras formas de interação, agregaremos à pesquisa algumas obras produzidas em outros idiomas que, por sua forma de elaboração, são essenciais para uma melhor compreensão do que ocorre quando se estabelece o diálogo entre quadrinhos e o material literário, independente da Língua em que são produzidas. A esse respeito, vale ressaltar que a incorporação de obras produzidas em 
outras línguas se dá pelo fato de haver elementos produzidos em diferentes países que alteraram decisivamente a forma de se fazer quadrinhos em Língua Portuguesa, seja na elaboração estética, cultural e/ou ideológica.

Para estudar a relação entre o material literário e as HQs não nos ateremos a uma teoria específica, na medida em que há poucas reflexões sobre a produção de Língua Portuguesa de quadrinhos, principalmente na sua relação com o material literário. Contudo, abordaremos importantes teóricos que estudaram desde a linguagem dos quadrinhos, a intertextualidade e o dialogismo, até a história social da arte e da literatura com importantes contribuições para a cultura mundial como Cândido, Coelho, Benjamin, Cirne, Cagnin, Eisner, McCloud, Bakhtin, Barthes e outros cujas reflexões abordam aspectos que fazem parte do roteiro de análise desse trabalho.

A organização desse estudo se dá de forma a trazer informações que possam colaborar para uma melhor compreensão da relação que as HQs estabelecem com o material literário. Assim, no Capítulo 1 iniciaremos com uma abordagem histórica sobre a relação entre as linguagens verbal e não-verbal, desde a pré-história até os dias atuais, com os quadrinhos. O objetivo é verificar como a união das linguagens permitiu, ao longo dos tempos, a criação de uma forma de diálogo própria e como, nos quadrinhos, tal forma de diálogo encontrou um contexto eficiente para a propagação de narrativas das mais diversas. 
A seguir, no Capitulo 2, verificaremos como se dá a construção das narrativas, quais seus códigos próprios e como eles se estruturam nos quadrinhos. Para tanto, destacaremos os elementos básicos da narração e procuraremos identificar os principais recursos estéticos das HQs, como se organizam e que efeitos podem suscitar. Conhecendo a forma como os quadrinhos realizam a união entre as linguagens verbal e não-verbal na prática de sua execução, poderemos compreender melhor como se dá a utilização desses recursos quando do diálogo com o material literário.

No Capítulo 3 estudaremos as formas de diálogo que podem ocorrer entre as HQs e o material literário. Abordaremos obras produzidas em quadrinhos que adaptam ou estabelecem outro tipo de relação com a literatura. Teremos desde adaptações pastiche, re-criações até o desenvolvimento de novas obras. Observando tais diálogos poderemos compreender melhor quais possibilidades interativas oferecem e como se relacionam com as obras consideradas clássicas atualmente. Agregaremos também à pesquisa, em outro subitem desse capítulo, obras produzidas na literatura que dialogam com o material dos quadrinhos, para compreendermos como se dá o movimento contrário, e outras que trazem em sua estrutura narrativa, tanto o texto literário quanto a construção própria dos quadrinhos, numa maneira diferente de realizar o diálogo entre obras. Após percorrermos os caminhos que se revelam quando da inter-relação entre os quadrinhos e o literário, poderemos verificar quais possibilidades oferece para nosso mundo atual, no que diz respeito à construção do saber cultural. 
Buscamos, assim, além de contribuir para os estudos acadêmicos, trazendo elementos que explicitem as diferentes possibilidades de diálogo, suas características, formas de realização e contribuição comunicativa, levantar questões que nos permitam reconhecer para que serve tal diálogo e quais as possibilidades interativas oferece para os leitores (antigos e novos) de meios tão complexos e ricos como são os quadrinhos e a literatura. Conhecermos melhor tal relação nos permitirá um novo olhar, um "olhar de descoberta" ${ }^{1}$, por meio do qual poderemos reconhecer que, como toda arte autêntica, a das HQs têm, como matéria prima, determinada experiência humana, resultante de determinado momento histórico.

\footnotetext{
${ }^{1}$ GÓES, Lúcia Pimentel. Olhar de Descoberta. São Paulo: Paulinas, 2003.
} 


\section{O VERBAL E O VISUAL - CONTEXTO HISTÓRICO}

"Foi esse homem pré-histórico (ainda ignorante da palavra e de seus poderes) que, ao querer expressar essas formas de vida ou a vida dessas formas (para transmiti-las aos outros), reproduziu em toscos traços a imagem do que pretendia comunicar. [...] Fora inventada a arte da ilustração que, através dos tempos, tem dividido com a palavra, a tarefa de expressar/comunicar vivências que extrapolam a mera compreensão lógica, porque pertencem à área do imaginário, do sonho, do sagrado ou do mistério da condição humana."

Nelly Novaes Coelho

Para se compreender a peculiar arte das HQs, - resultante da intersecção da linguagem verbal com as variadas formas de comunicação visual (visualidade, hoje, dominante nos meios de comunicação de massa) e sua relação com a literatura é necessário que se refaça o caminho da história da linguagem, fator essencial na formação e existência de toda e qualquer comunidade humana. O Homem com sua característica necessidade de relacionamento social desde que nasce é instintivamente levado a usar a fala para comunicar-se com os demais. Necessidade de comunicação que, a partir da linguagem verbal, e através dos milênios, foi assimilando novas formas de comunicação até chegar ao nosso tempo com as complexíssimas formas cibernéticas de comunicação. 


\subsection{Pré-História}

Tudo teria começado, provavelmente, com a emissão de sons, com gestos e rabiscos traçados em argila, pedras, etc. Iniciava-se assim a grande saga da comunicação humana. As primeiras formas de manifestação comunicativa, gravadas pela espécie humana, e de que se têm conhecimento, são os desenhos pré-históricos encontrados em cavernas, como os da gruta de Lascaux, no sul da França (Fig. 1), e os de Altamira, no norte da Espanha. São pinturas de touros, cavalos, mamutes e outras formas animais, cuja provável significação vem sendo objeto de estudos arqueológicos, desde o século XIX.

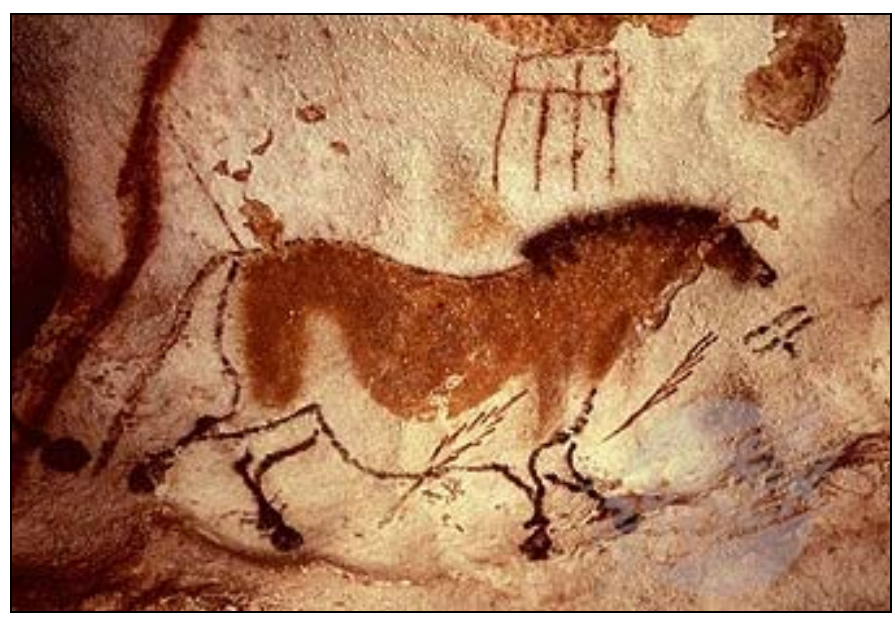

Fig. 1- Caverna de LASCAUX, França. As pinturas rupestres, que têm 17.000 anos, foram encontradas em 1942. Na imagem, o desenho de um cavalo, 15.000-10.000 a.C.

Já nessa remota época, quando os primitivos traçavam suas primeiras formas de comunicação registrada nas paredes das cavernas, é possível identificar determinadas técnicas de representação que ainda hoje são utilizadas, sobretudo nas histórias em quadrinhos, como ressalta Jean-Bruno Renard (1981, p.18): 
Primeiramente o uso do traço negro, ou gravado, que indica o contorno da personagem ou do animal; linha que não existe na natureza, e que constitui apenas uma convenção de representação [...] a enorme importância numérica das figuras desenhadas de perfil [...] parece corresponder a vontade de representar seres em movimento e não de personagens 'em pose'[...]; a arte pré-histórica [...] é simbólico-figurativa [...] ao desejar imitar o real, o artista minimiza ou exagera certos aspectos gráficos a fim de dar aos seus desenhos mais sentido, mais significado.

Exemplos de pinturas rupestres registradas em rochas e grutas também são encontrados no Brasil, como os do Estado do Piaú́, no Parque Nacional da Serra da Capivara (Fig. 2). Os sítios arqueológicos, que passam de 500, dos quais 360 são feitos pelos homens pré-históricos, trazem pinturas que mostram uma crônica da sociedade que vivia na região do Sudeste do Piauí, revelando sua vida cotidiana, cerimônias e mitos.

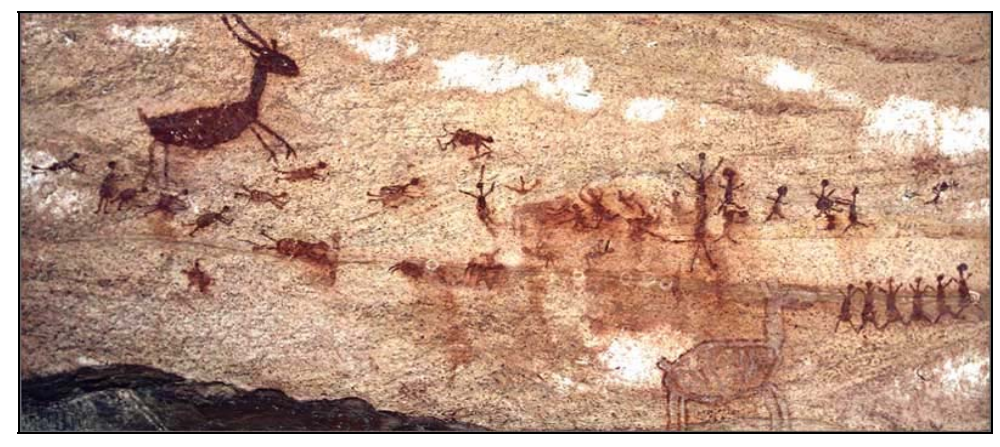

Fig. 2- No Parque Nacional da Serra da Capivara, os vestígios de sociedades primitivas revelam com riqueza de detalhes o cotidiano da vida de seus habitantes.

O registro de aspectos sociais e culturais das sociedades, aliás, é a principal característica das primeiras formas de comunicação dos seres humanos. O que se observa é que as manifestações artísticas são coextensivas à vida social, e se revelam como um ponto de equilíbrio coletivo e individual, sendo, portanto, socialmente necessárias para a expressão, comunicação e integração. A arte, como explica Antônio Cândido (2000, p.19), é social em dois sentidos: “[...] depende da ação de fatores do meio, que se 
exprimem na obra em graus diversos de sublimação; e produz sobre os indivíduos um efeito prático, modificando a sua conduta e concepção do mundo, ou reforçando neles o sentimento dos valores sociais”. No caso do homem pré-histórico, a atividade artística mantém uma ligação ainda mais estreita com a vida social e seus fatores básicos.

A criação estética do homem primitivo parece estar ligada diretamente à necessidade de sobrevivência, e para ser compreendida precisa ser vista sob essa ótica. É a experiência e a necessidade do grupo que desencadeiam tais manifestações estéticas. Os traços e desenhos rupestres representam uma enorme descoberta para o conhecimento das sociedades da época, suas formas de interação e comunicação. A partir daí podemos traçar uma linha que nos mostra as diversas tentativas do homem para registrar a história que vivia e a vida que se revelava à sua frente. Destacando a importância das obras préhistóricas para a sociologia da arte, Arnold Hauser (1972, p.40), afirma que tais registros “[...] permitem descortinar, com maior nitidez o que acontece na arte das épocas posteriores, o sistema de relações entre as estruturas sociais e as formas artísticas”.

\subsection{Surgimento da linguagem escrita}

A partir desse início, no qual a imagem impera, o processo comunicativo tornouse cada vez mais complexo. A escrita ${ }^{2}$ foi um importante passo no desenvolvimento da comunicação. Se comparada com os milhares de anos que compreendem a existência

\footnotetext{
2 David Diringer define a escrita como uma atividade ligada intrínseca e inseparavelmente ao desenvolvimento comparativamente recente do intelecto consciente do homem (DIRINGER, 1971)
} 
humana, o surgimento da linguagem escrita teve uma origem recente, datando de cerca de 4.000 anos a.C.

O sistema de escrita mais antigo de que se tem conhecimento é o cuneiforme, com caracteres em forma de cunhas e pregos, surgido na região da Mesopotâmia. É também dessa região um dos primeiros documentos literários encontrados, o Fâra/Abû-Salâbîh, um conjunto de 4 ou 5 pequenas tábuas e fragmentos em que há trechos de espécies de cantos religiosos ou hinos de um lado e 'conselhos de um pai ao seu filho' de outro.

O hieroglífico egípcio foi outro importante sistema de escrita surgido ainda no início do terceiro milênio a.C. Um dos mais antigos e conhecidos registros da escrita egípcia é a Tábua de Narmer (Fig. 3), da região do Alto Egito.

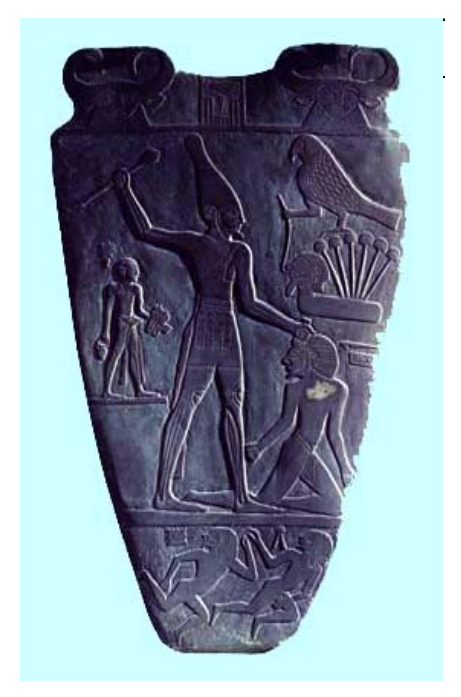

Fig. 3- Tábua de Narmer (Museu do Cairo, Egito). Trata-se de uma representação mais ou menos pictográfica, apresentando imagens juntamente com uma forma de escrita semifonética (DIRINGER, 1971). 
Em Creta, a escrita evoluiu da gravação de sinetes (em esteatita e marfim) esculpidos com desenhos simples, até a denominada pela Arqueologia como Linear A e Linear B, mais cursiva e modificada. Na China, os documentos mais antigos conhecidos datam de meados dos anos 2000 a.C. São inscrições de oráculos em ossos de animais e carapaças de tartaruga, além de vasos de bronze, armas, olaria e jade.

Segundo Thomas Clark Pollock (1942, apud Cândido, 2000, p.34) ${ }^{3}$, a invenção da escrita "tornou possível a um ser humano criar num dado tempo e lugar uma série de sinais, a que pode reagir outro ser humano, noutro tempo e lugar”. Há quem considere o surgimento da linguagem escrita o marco que fez surgir o indivíduo destribalizado ${ }^{4}$. O rompimento com a natureza tribal, por sua vez, possibilitou a evolução da comunicação humana, que partiu de sons primitivos e gestos, passou pelos primeiros traços marcados nas paredes das cavernas, até chegar na escrita, no teatro, nas esculturas, nas histórias em quadrinhos, no cinema, no rádio, na televisão e, agora, na realidade virtual (BACELAR, 2007).

A necessidade de comunicar, estabelecida em um determinado momento da existência humana, expressa o marco diferenciador do homem em relação aos outros animais: ele se comunicava e podia registrar essa ação de alguma forma, eternizá-la. Tal ato marca “[...] o registro durável de uma forma de ler o mundo. Um mundo que se revela através de uma experiência que deseja se comunicar aos outros” (COELHO, Ibidem, p.4).

\footnotetext{
${ }^{3}$ POLLOCK, Thomas Clark. The nature of literature, Its relation to Science, Language and Human ce. Princeton, 1942, págs. 16-17

${ }^{4}$ Para McLuhan, nenhum outro modo de escrever é tão destribalizante como o alfabeto fonético, que "desprende o homem do domínio possessivo de total interdependência e inter-relação que é o do mundo auditivo”. (McLUHAN, 1972, p.46).
} 
O processo de representar/simbolizar cada ser, planta ou fenômeno da natureza, trazia em si, além da busca por conhecimento e reconhecimento, a de domínio, afinal se, como afirmou Foucault (1999) o homem é linguagem, podemos concluir que, para constituir o mundo a sua volta era preciso que o ser humano o nomeasse.

Assim, o ato de nomear o reconhecimento de mundo, inicialmente por sons e gestos e depois por meio do registro, seja pela linguagem verbal ou pela não-verbal, criou significados, realidades e estabeleceu novas relações de tempo-espaço, pois como ressalta Maria Zilda da Cunha (2002, p.83), “toda mudança no modo de produzir linguagens afeta inevitavelmente a forma como percebemos o mundo, a imagem que temos desse mundo".

\subsection{Letras e desenhos nas sociedades}

Desde o surgimento dos primeiros traços nas paredes das cavernas até os dias de hoje, com a cibercultura, as palavras e os desenhos são importantes ferramentas para a comunicação. Vale destacar que a relação entre ambas linguagens tem variado ao longo do tempo. Inicialmente tínhamos os desenhos das cavernas; com o surgimento da escrita vemos o nascimento do texto ilustrado que, como destaca Renard (1981), se encontra na origem dos quadrinhos.

A relação entre o texto verbal e o não-verbal acontece antes mesmo de haver livros impressos. Segundo Angela Lago (2008), a interação entre as linguagens já ocorria 
em determinados manuscritos, nos quais é possível encontrar ilustrações para narrar e gerenciar o texto verbal, tornando-o assim mais acessível àqueles que não sabiam ler.

Com essa função, os códigos simultâneos também foram utilizados pela Igreja, como é o caso da Bíblia Pauperum (Bíblia dos Pobres), na qual a ilustração surge como representação do texto verbal, servindo assim para doutrinar os iletrados, que naquela época eram a maioria, uma vez que bem poucos tinham acesso à educação (Fig. 4).

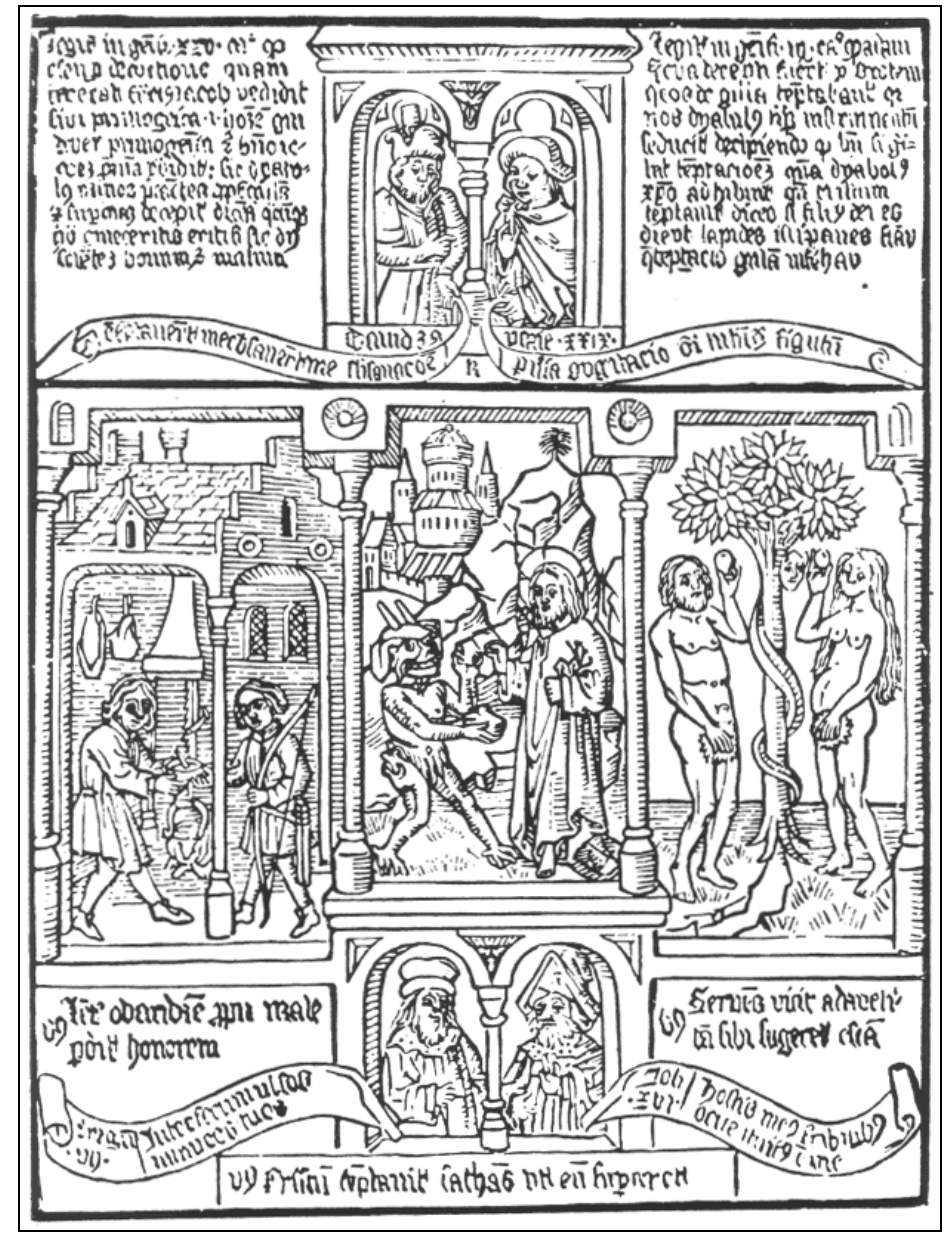

Fig. 4- As cenas ilustram a tentação de Esaú, a tentação de Cristo e a tentação de Adão e Eva. O uso de figuras na Bíblia Pauperum tornava mais compreensíveis certas passagens bíblicas, sobretudo para quem não sabia ler. 
O mesmo ocorre com os vitrais, que exibiam cenas religiosas e histórias do Antigo e do Novo testamento. No século VI, o papa Gregório Magno afirmava que a pintura poderia fazer pelos analfabetos o mesmo que a escrita pode fazer por aqueles que sabem ler (LAGO, Ibidem).

A invenção da tipografia foi fator decisivo para a relação da linguagem verbal com a não-verbal. Desenvolvida por Gutenberg por volta de $1450^{5}$, a nova tecnologia possibilitou a reprodução de textos verbais e ilustrações, tornando-os acessíveis a muitos. Como ressalta McLuhan (1972), quando Gutenberg desenvolveu a imprensa também inventou o público e como diz Carramillo Neto (1987, p.12), “Não só inventou o público, de modo geral, mas criou um público leitor de letras gráficas e impressas, ampliando as possibilidades de conhecimento e de comunicação dos homens”.

No que diz respeito às ilustrações, já com a xilogravura sua reprodução se tornou possível, isso antes que a imprensa fizesse o mesmo com o texto verbal:

\footnotetext{
“À xilogravura, na Idade Média, seguem-se a estampa em chapa de cobre e a água forte, assim como a litografia, no início do século XIX [...] A litografia [...] permitiu às artes gráficas pela primeira vez colocar no mercado suas produções não somente em massa, como já acontecia antes, mas também sob a forma de criações sempre novas” (BENJAMIN, 1969, p.166).
}

Antes da invenção da imprensa, os textos eram reproduzidos manualmente, de forma artesanal, o que reduzia a quantidade de exemplares e a qualidade dos mesmos, pelo fato de poder ocorrer erros ao copiar do original. A reprodução em massa se tornou

\footnotetext{
${ }^{5}$ Mário Carramillo Neto (1987) destaca que, apesar de ter sido Gutemberg o criador da Impressão Tipografia em tipos móveis, os chineses, por volta do ano 868 da nossa era, já fundiam tipos móveis em porcelana e bronze. Mas de acordo com sua escrita, gravavam em madeira ou metal que era mais econômico para a época.
} 
possível através da tipografia, que se configurou como "uma das principais alavancas do desenvolvimento científico e técnico que marcou o início da Idade Moderna e acabou, mais tarde, gerando ambiente e condições para que a Revolução Industrial pudesse acontecer" (AZEVEDO, 2002, p.1).

Dos primeiros sons e aceno emitidos pelos homens das cavernas, à descoberta do alfabeto, a linguagem verbal escrita se sobrepôs à linguagem não-verbal durante séculos. A civilização ocidental fundou-se sobre a palavra de Deus (valor absoluto). O Renascimento, por seu lado, marcou um afastamento entre as linguagens verbal, veiculada sobretudo nos livros, e não-verbal (que se restringia aos quadros).

No mundo contemporâneo, por sua vez, temos um amplo uso da linguagem nãoverbal, mediada pelos meios de comunicação de massa e tecnológicos. Esse fato ocorreu devido a uma nova mentalidade que se instaura a partir do século XIX (Revolução Industrial): "Da linguagem verbal partimos para a não verbal, através da ruptura da razão tradicional/cartesiana, provocada pela 'morte de Deus': a palavra fundadora é negada; o mundo perde o seu centro sagrado (Deus). Cada ser, cada 'eu’ passa a ser o centro que, para se sentir legitimado, precisa ser reconhecido pelo centro do outro - o 'eu' é legitimado pelo olhar do 'tu'” (informação verbal) ${ }^{6}$.

Partimos, então, do pensamento racionalista (Descartes), que separa, cataloga, põe limites entre as várias áreas do saber, para o pensamento complexo (Edgar Morin) que descobre o mundo como uma rede inextrincável de relações. Da Revolução Industrial,

\footnotetext{
${ }^{6}$ Informação fornecida por Nelly Novaes Coelho, em 2005.
} 
que alterou as relações concretas entre os homens (sistema econômico/político)

caminhamos para a revolução tecnológica, que está alterando as relações abstratas. Como

ressalta Coelho (2007, p.1), temos o:

[...] confronto entre o mundo das certezas, herdado da tradição (fundado na concepção cartesiano-newtoniana, racionalmente explicável por leis naturais, simples e imutáveis), e o mundo das incertezas, gerado pelo nosso tempo de transformações (mundo complexo, desvendado pela Física einsteniana que põe em xeque as leis simples e imutáveis em que se apoiava o conhecimento herdado). [...] No lugar do sujeito seguro, baseado em certezas absolutas (fundado no pensamento tradicional: positivista, empirista, determinista), está hoje um sujeito interrogante que (tal qual o aprendiz de feiticeiro), diante desse mundo belo/horrível, em acelerada transformação (e que ele mesmo criou), tenta encontrar um novo centro ou novo ponto de apoio, para uma nova ordem (mesmo que seja provisória), em meio ao oceano de dúvidas e incertezas que $\mathrm{o}$ assaltam.

É importante lembrar que, seja na época dos traços borrados nas paredes das cavernas, seja agora com a revolução digital, o homem é o agente principal desse processo que visa reconhecer e dominar o mundo complexo que o rodeia. Os quadrinhos, meio em que a união das linguagens verbal e não-verbal assume características próprias, surgem dentro da busca humana por se relacionar e se comunicar com a sociedade, e suas origens são antigas na história das civilizações.

\subsection{Os quadrinhos e o encontro entre o verbal e o visual}

Como foi destacado, as linguagens verbal e não-verbal têm sido usadas pelos indivíduos para elaborar as mais variadas formas de comunicação, e a história em quadrinhos representa, nesse contexto, um importante meio em que a união de ambas propiciou elaboradas maneiras de registrar e expressar as experiências humanas. Com 
origens nas pinturas rupestres, os quadrinhos, da forma moderna como os conhecemos, em que a união entre as linguagens se revelam essencial para sua expressão, surgiram no fim do século XIX e se consolidaram como um importante veículo de comunicação de massa. Mas o início das narrativas construídas a partir de uma seqüência de imagens é antigo. Conforme revela Scott McCloud (2002), alguns exemplos desse tipo de construção narrativa podem ser encontrados em manuscritos pré-colombianos, descobertos por Cortês em 1519 e que narram a aventura épica do grande herói militar e político “garras de tigre”, ou em tapeçarias, como a francesa Bayeux Tapestry, que conta em 70 metros a conquista normanda da Inglaterra em $1066^{7}$. A arte seqüencial, assim como outras formas de expressão humana, surge ligada ao registro de aspectos sociais e cotidianos das sociedades, como no caso dos hieróglifos egípcios, que trazem pintados em paredes e muros, cenas do dia a dia do povo, episódios relacionados às práticas religiosas e à vida na côrte, como as encontradas nas Mastabas (Fig. 5), túmulos dos nobres das $5^{\mathrm{a}}$ e $6^{\mathrm{a}}$ Dinastias.

\footnotetext{
${ }^{7}$ Segundo Arnold Hauser (1982), as tapeçarias de Bayeux apresentam num estilo notavelmente fluente, muitos e variados episódios, além de grande realismo.
} 


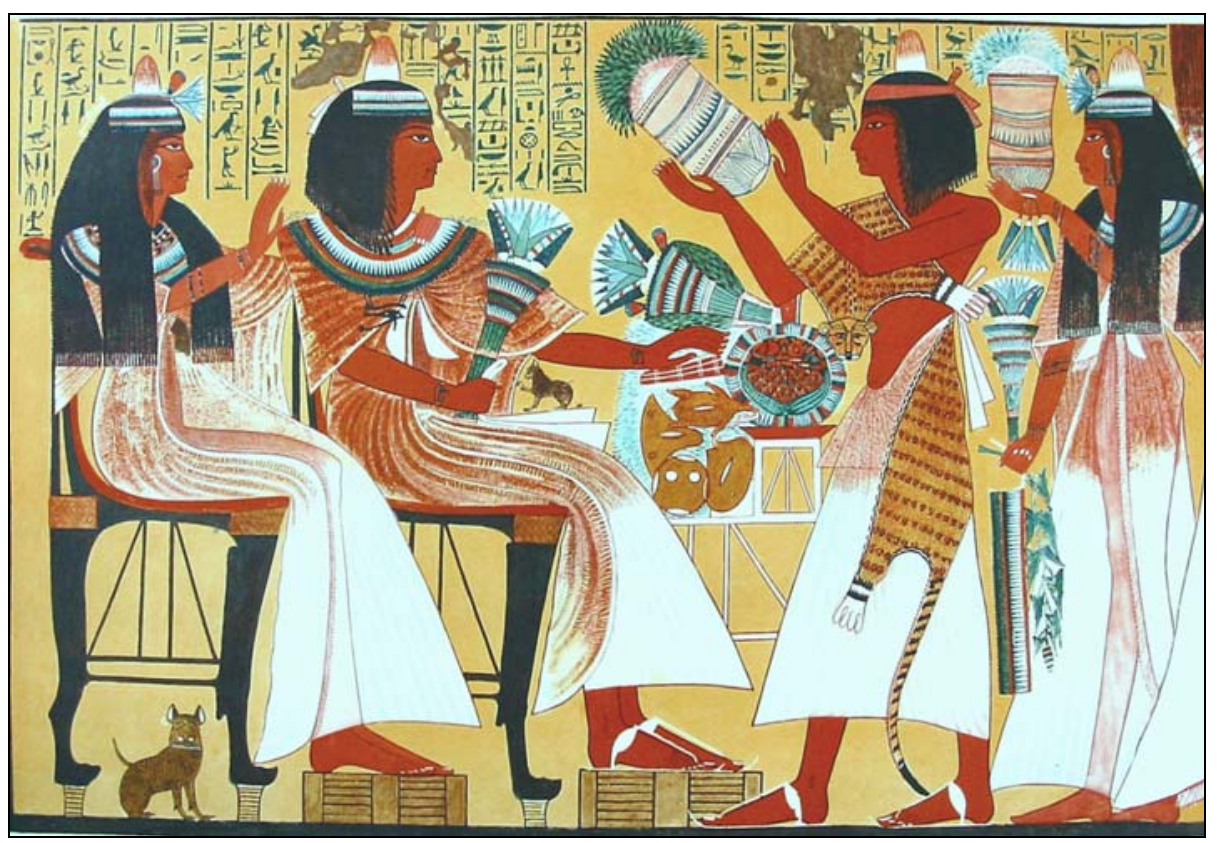

Fig. 5 - Na parede das Mastabas encontram-se registrados vários aspectos do cotidiano e crenças do povo, como essa em que o filho e a filha oferecem buquê de Amon ao morto, que segura um filhote de gato, e à sua esposa, cuja cadeira encontra-se em cima de outro gato.

Os quadrinhos foram um dos primeiros meios de comunicação de massa a se globalizar, antes mesmo do cinema. As HQs, com as características que conhecemos atualmente, foram prenunciadas na Europa com as novelas e histórias ilustradas de Rodolphe Topffer (1799-1846), escritor, artista e professor universitário natural de Genebra. Suas Histoires en Estampes (Fig. 6), reunidas entre 1846-47 e que obtiveram enorme sucesso, trazem uma narração figurada, com várias imagens separadas por um traço vertical e colocadas sobre um breve texto (COUPERIE, 1970). Na fala do próprio Topffer (MOYA et al, 1994, p.9), sua criação se caracterizava pela natureza mista:

Ele se compõem de uma série de desenhos autografados em traço. Cada um destes desenhos é acompanhado de uma ou duas linhas de texto. Os desenhos, sem este texto, teriam um significado obscuro, o texto, sem o desenho, nada significaria. [...] Aqui, como um conceito fácil, os tratamentos de observação, o 
cômico, o espírito, residem mais no esboço propriamente dito, do que na idéia que o croqui desenvolve.

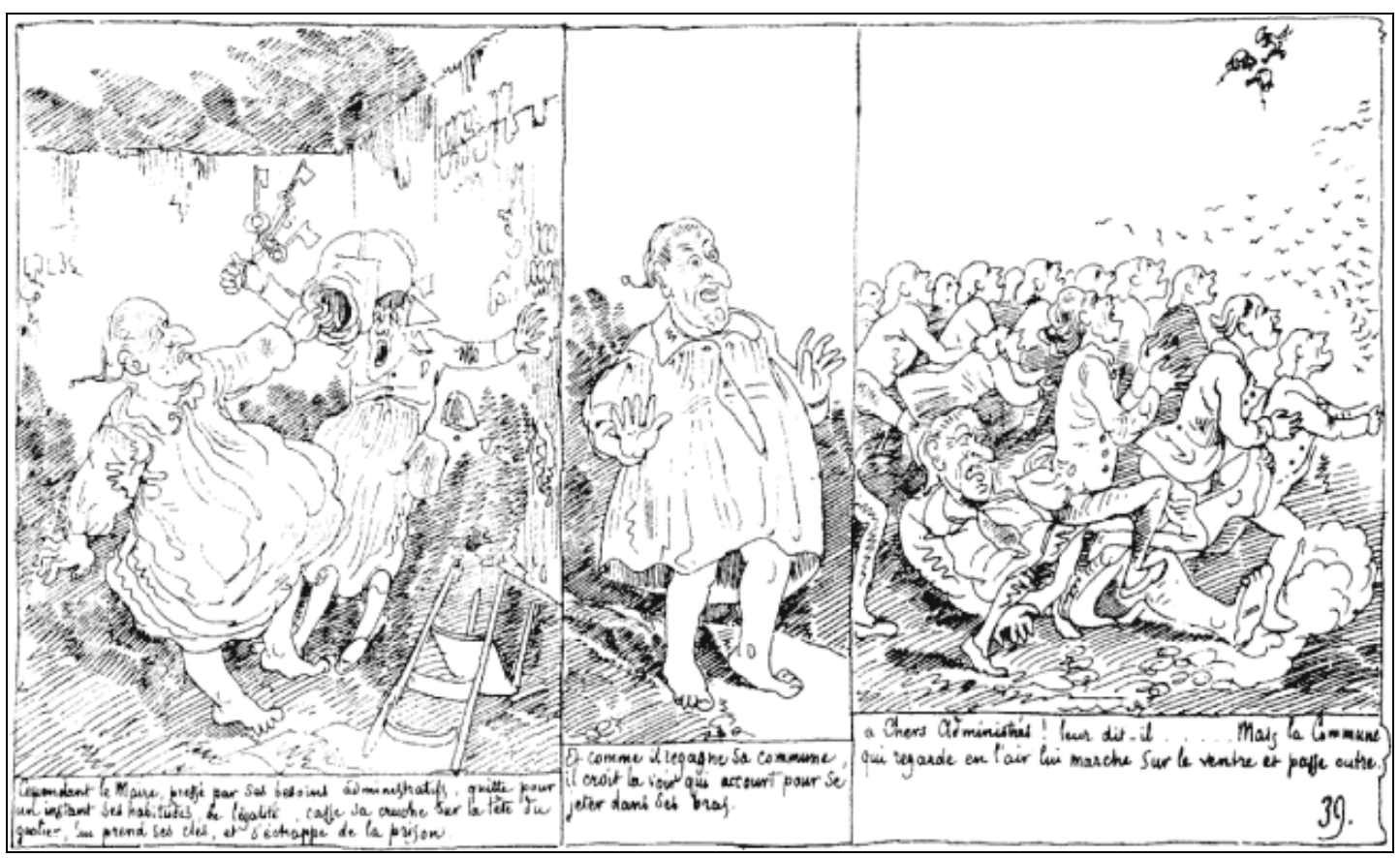

Fig. 6- Trecho da obra Histoires en Estampes de Topffer. Apesar de ainda não aparecer os balões, a união das linguagens verbal e não-verbal é vital para a compreensão da obra como um todo, elaborada a partir da seqüência dos quadros que se sucedem na página.

Alguns estudiosos apontam como precursor dos quadrinhos no formato moderno, ao invés de Topffer, as aventuras bem humoradas dos moleques traquinas Max und Moritz do alemão Wilhelm Bush (1832-1909). Outros destacam as estórias do francês Georges Colomb sobre um casal provinciano e suas duas filhas, a Fammille Fenouillard, criada em 1889. Independente de sua real origem, contudo, são nos Estados Unidos que as HQs florescem e encontram grande sucesso. No início, os quadrinhos foram identificados pelas características que desenvolveram na imprensa jornalística norteamericana, pois foi lá que a sua difusão se deu de forma mais agressiva (VERGUEIRO, 
2006). Os primeiros quadrinhos americanos aparecem nos jornais, em páginas dominicais ou tiras diárias, e seu principal objetivo era o humorístico.

Uma importante figura que marca a história dos quadrinhos é a da célebre personagem Yellow Kid, criado por Richard Felton Outcault em 1895. Essa, aliás, é considerada por muitos como a primeira história em quadrinhos continuada, e trazia semanalmente as estórias de um garoto de camisolão amarelo, cabeça grande e enormes orelhas.

As estórias do Yellow Kid se passavam no beco de Hogan, local onde a maioria dos habitantes era composta por indivíduos de etnias não norte-americanas. A esse respeito Waldomiro Vergueiro destaca (2001, p.1):

O colosso ianque desejava aculturar as levas de imigrantes que passara a abrigar e as histórias em quadrinhos apareciam como o instrumento por excelência para atingir esse objetivo. Eram baratas. Eram fáceis de compreender. Eram atrativas ao leitor com pouco conhecimento do idioma inglês. E, além de funcionarem muito bem em todos esses quesitos, atingiam em cheio o seu público e contribuíam para uniformizar as diversas etnias em torno de uma maneira única de encarar o mundo.

Em termos de disseminação, as HQs tiveram ampliado o seu consumo com a ajuda dos Syndicates. Criados a partir da primeira década do século 20 pelos jornais, para contratar e vender o trabalho dos desenhistas, os Syndicates se configuram como grandes distribuidores de quadrinhos nos Estados Unidos e no mundo. A ampla distribuição, entretanto, acabou por contribuir para o aparecimento dos "modelos" de histórias, estabelecendo padrões que deveriam ser seguidos para que os quadrinhos pudessem ser publicados em todos os jornais. Temas como a família americana e a sociedade de consumo tornam-se uma constante nas HQs a partir de então. 
No Brasil, um dos primeiros a produzir quadrinhos foi o ítalo-brasileiro Angelo Agostini, que em 1867 já publicava algumas histórias ilustradas. Segundo revela Waldomiro Vergueiro (2004, p.1), o Brasil deu decisiva contribuição para o estabelecimento da linguagem quadrinizada: "Na segunda metade do século 19, o ítalobrasileiro Angelo Agostini desenvolveu uma intensa atividade de crítica social por meio do humor gráfico nos jornais ‘Diabo Coxo’ e ‘O Cabrião’”.

Em 1869, Agostini lançou no jornal Vida Fluminense, As Aventuras de Nhô Quim ou Impressões de uma viagem à Corte (Fig. 7), considerada por muitos como a primeira produção em quadrinhos do mundo, por ter sido produzida com quase 30 anos de antecedência em relação àquela que é considerada como a precursora, a americana 'Yellow Kid'. É bom lembrar que, desde o início as obras nacionais de quadrinhos sofreram com a competição da produção estrangeira, sobretudo a americana, que domina grande parte do mercado até hoje. 


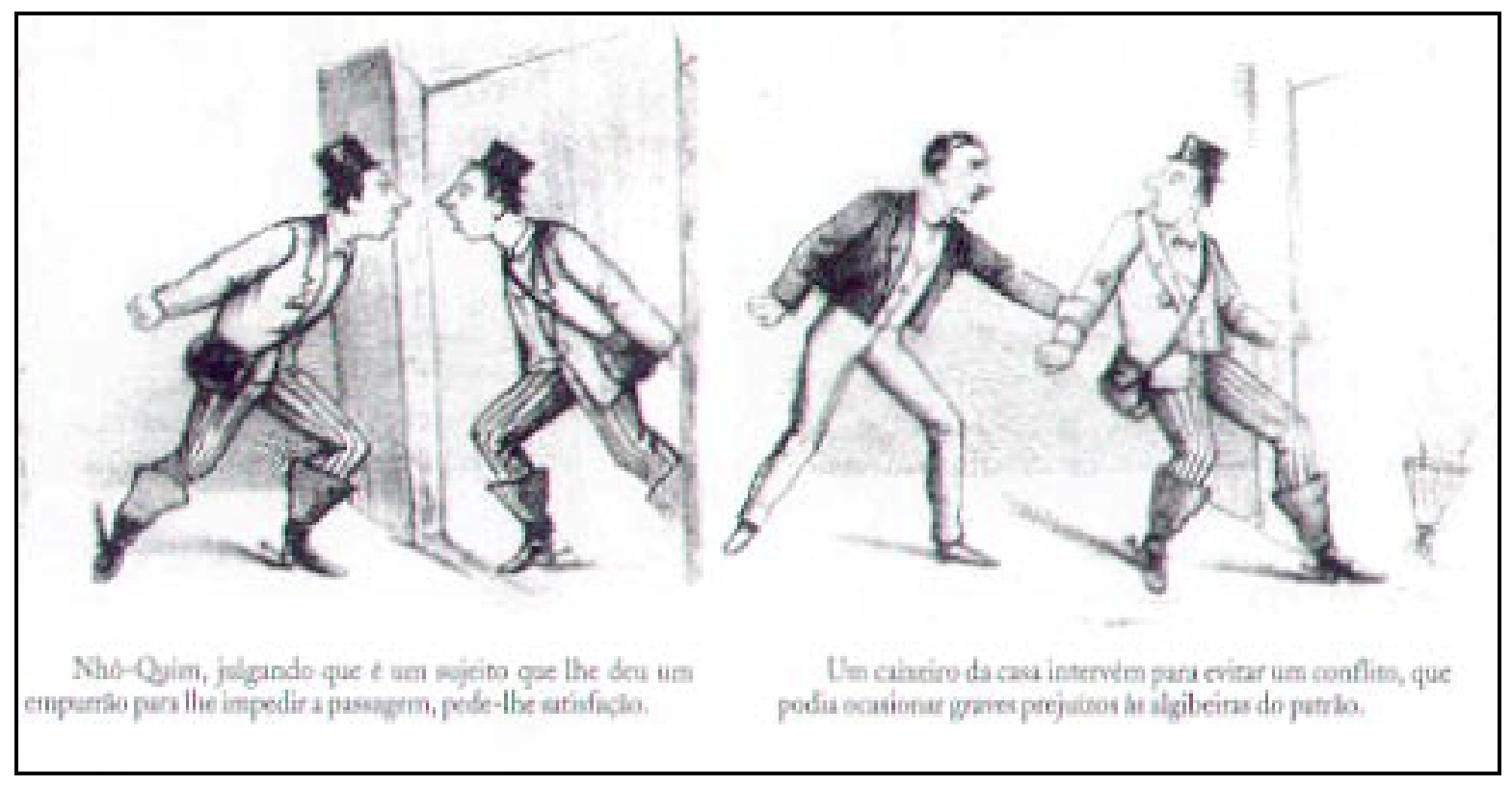

Fig. 7- Na ilustração, Nhô-Quim estranha seu próprio reflexo no espelho.

Não se pode falar dos quadrinhos nacionais sem destacar o nome da revista $O$ Tico-Tico, lançada por Angelo Agostini em 1905, e que é vista como uma das primeiras a publicar quadrinhos no país. ${ }^{8}$ Além do Suplemento Juvenil e de outras publicações como A Gazetinha e o Globo Juvenil, foi a revista Gibi, também da editora Globo, que teve seu nome emprestado para todas as publicações do gênero.

Com o lançamento do Suplemento Juvenil de Adolfo Aizen na década de 30, muitos heróis famosos chegaram às bancas brasileiras, como Flash Gordon, Tarzan e Mandrake, dentre outros. Na década de 40, uma importante inovação promovida pela editora Brasil America Limitada (EBAL), sob o comando de Aizen, foi o lançamento das Edições Maravilhosas, com obras literárias quadrinizadas.

\footnotetext{
${ }^{8}$ Como explica Gonçalo Junior (2004), a revista O Tico-Tico, que não trazia apenas quadrinhos, mas também textos e passatempos, foi responsável pela introdução dos comics infantis e do humor na imprensa brasileira.
} 
Na década seguinte, personagens de rádio, televisão e cinema, como Grande Otelo, Oscarito e Mazzaropi também surgem nas histórias em quadrinhos. Mas é na década de 60 que os quadrinhos brasileiros apresentam uma obra com características realmente nacionais (Fig. 8):

A produção dos quadrinhos brasileiros tem seu marco divisor no Pererê (1960/64), de Ziraldo. Estabelecendo seus parâmetros narrativos no interior da engrenagem da cultura de massa, Ziraldo conseguiu penetrar na realidade nacional da época com bastante agudeza crítica. Filiava-se [...] à atividade intelectual que engendrou (e/ou desenvolveu) a bossa nova, a poesia concreta, o cinema novo, os 'centros populares de cultura', com todas as contradições do processo histórico daquele momento preciso (CIRNE, 1975, p.91).

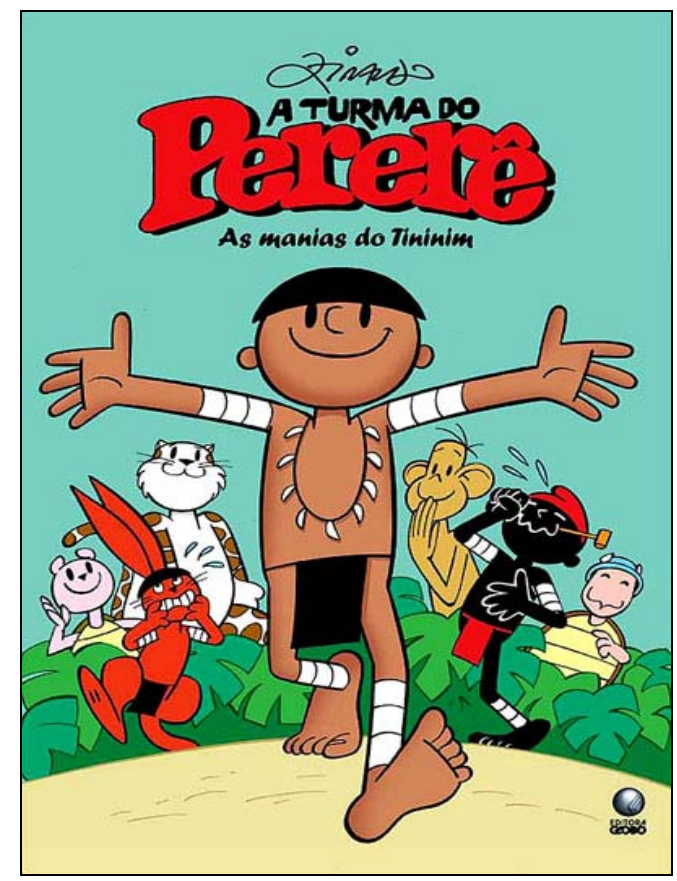

Fig. 8 - Capa do livro, A turma do Perere: as manias do Tininim (Ziraldo, 2007). A turma do Pererê trazia personagens bem brasileiras, como o Saci, a onça Galileu, o índio Tininim e outros.

Apesar dos diversos problemas enfrentados pelo mercado de quadrinhos brasileiro, como a concorrência estrangeira, que chegava barateada devido aos syndicates, a falta de uma estrutura de produção, divulgação e distribuição, dentre outros 
fatores ${ }^{9}$, um nome se destaca: Maurício de Souza. Com personagens que se consagraram, Maurício conseguiu montar uma estrutura capaz de atender as necessidades do mercado.

A produção brasileira de quadrinhos, desde suas primeiras aparições no mercado nacional, se diversificou com obras realizadas em diferentes gêneros, do infantil ao terror, dos eróticos aos humorísticos, apresentando nomes de peso como Edgar Vasques, Henfil, Luiz Gê e muitos outros.

Ao longo de sua história, os quadrinhos em todo o mundo alcançaram grande sucesso e enfrentaram períodos de dificuldade, como destaca Vergueiro (2004, p.1):

As campanhas difamatórias e o aparecimento de um pujante meio de comunicação de massa, a televisão, trouxeram aos quadrinhos momentos de dificuldade, superados por autores e editores em cinco décadas de luta. As lojas especializadas, que se multiplicaram no final dos anos 70, trouxeram alento para a área, mas não colaboraram para a renovação de leitores. Enquanto isso, as "graphic novels" buscaram um público adulto, tendência explorada por fanzines e revistas alternativas. Os quadrinhos iniciam o século 21 em busca de amadurecimento, de legitimação como linguagem artística e de ampliação de seu público para camadas mais eruditas. Ao mesmo tempo, a comunicação eletrônica levou os quadrinhos a recorrer a uma linguagem híbrida, em que elementos tradicionais da linguagem gráfica seqüencial convivem com contribuições_oriundas da informática, da animação e do cinema.

\footnotetext{
${ }^{9}$ Sobre o mercado estrangeiro de quadrinhos, Coelho (1981) lembra que a produção internacional conta com um mercado já trabalhado para consumi-los, uma vez que são maciçamente divulgados pela televisão, cinema, etc.
} 


\section{A CONSTRUÇÃO NARRATIVA E SEUS CÓDIGOS}

"Inumeráveis são as narrativas do mundo. Trata-se primeiramente de uma variedade prodigiosa de gêneros, distribuídos entre substâncias diversas, como se qualquer matéria servisse para o homem confiar suas narrativas: a narrativa pode ser sustentada pela linguagem articulada, oral ou escrita pela imagemm fixa ou móvel, pelo gesto e pela mistura ordenada de todas estas substâncias”

Roland Barthes

Após percorrer o caminho histórico das linguagens verbal e não-verbal em sua relação ao longo dos tempos, e o surgimento dos quadrinhos, veiculo no qual a fusão das linguagens permitiu novas formas de narração, vejamos agora como se dá a construção de narrativas e quais os códigos que fazem parte da mesma, uma vez que é por meio das estórias desenvolvidas pelas diversas sociedades que podemos verificar como as linguagens se comunicam e, conseqüentemente, como as artes dos quadrinhos e da literatura, que fazem uso dessas linguagens, dialogam na sua estrutura narrativa.

Construir narrativas, prática tão antiga na história, é um importante aspecto da cultura humana. Como pudemos observar no capítulo anterior, o ser humano tem buscado meios para se expressar desde tempos remotos, de narrar suas estórias, registrar aquilo que vê, ouve, pensa e discute na sua relação com o meio e a sociedade onde vive. As linguagens verbal e não verbal, por seu lado, foram e têm sido, até hoje, ferramentas vitais para a expressão humana, possibilitando o registro e propagação de inúmeras 
narrativas que chegaram até nós, e ainda são produzidas em nosso meio nos mais variados suportes.

O ato de 'contar' histórias faz parte e está enraizado no comportamento das sociedades humanas desde os primórdios. Como revela Eisner (2005, p.11-13):

As histórias são usadas para ensinar o comportamento dentro das comunidades, discutir morais e valores, ou para satisfazer curiosidades. Elas dramatizam relações sociais e os problemas de convívio, propaga idéias ou extravasa fantasias. [...] Uma história tem um início, um fim, e uma linha de eventos colocados sobre uma estrutura que os mantêm juntos. Não importa se o meio é um texto, um filme ou quadrinhos. O esqueleto é o mesmo. O estilo e a maneira de se contar pode ser influenciado pelo meio, mas a história em si não muda.

As narrativas surgem nas comunidades para diversos fins, servindo para discutir desde questões sociais até aquelas ligadas à subjetividade de cada indivíduo. Elas nascem vinculadas à existência social do indivíduo, à vida em grupo, e como tais, se tornam veículos para a representação dos comportamentos humanos. Expressando aspectos do indivíduo e da sociedade, as narrativas trazem à tona ideologias que, segundo José Nicolau Gregorin Filho (1995, p.7), “sendo uma 'visão de mundo' de uma classe na sociedade [...] comporta várias ideologias, cada uma lutando para se impor dentro de um mesmo espaço cultural dos grupos sociais. Essas 'lutas' geram os discursos que vão ser representados através de textos”. Cândido (2000) lembra que as ideologias e os valores contribuirão, sobretudo para a constituição do conteúdo, já as modalidades, os meios de comunicação, terão maior influencia na forma. Assim, os diferentes suportes de comunicação influenciarão o estilo, o modo como se conta, enquanto que os conteúdos, independente do meio no qual a narrativa é produzida, sofrerão as influencias das 
ideologias, das diferentes maneiras como a sociedade e os grupos que fazem parte dela vêem e interagem com o mundo.

As narrativas trazem em si uma estrutura interna que está ligada ao próprio conceito de narração. Mesmo que a forma de apresentação não seja a convencionalmente usada (princípio, meio e fim) e o modo de elaboração também se apresente de maneira diversa, as diferentes narrativas se aproximam no grande objetivo de contar estórias.

Devido à necessidade de narrar, o ser humano buscou meios para tornar tal ato mais eficiente. Inicialmente as comunidades não dispunham de muitas ferramentas para se comunicar. Eram os gestos, sons e rabiscos nas paredes. A ampliação dos meios de comunicação, principalmente no processo de massificação das sociedades, multiplicou e modificou a capacidade de se expressar, possibilitando diferentes maneiras de se construir narrativas.

\subsection{0 código narrativo}

Para contar uma estória, independente do suporte comunicativo, faz-se necessário reunir um conjunto de elementos que permitam sua expressão. Como explica Cagnin (1975, p.155),

A narração é assim um produto de unidades articuladas segundo certos princípios. É uma série organizada de acontecimentos. Ainda que selecione fatos reais e da vida, ela não é uma mera cópia da vida. Estabelece unidades e, organizando-as, forma um conjunto de normas, o código narrativo. 
Tais elementos, por sua vez, se configuram como o tecido da narrativa, a trama, o discurso, aquilo que, com base nos formalistas russos, podemos chamar de syuzhet, e por meio dos quais criaremos nossa interpretação daquilo que vemos/lemos/percebemos na interação com a obra.

As 'pistas' fornecidas pelos realizadores das narrativas poderão tanto auxiliar como, e talvez propositalmente, dificultar o processo de compreensão. A trama, que representa a arquitetura da obra, nos fornece dados referentes: à narrativa (no que diz respeito às relações causais, os paralelismos, etc.), ao tempo (duração, frequiência, seqüências, etc.) e ao espaço (o que é relevante, secundário, central, etc.).

É por meio desses elementos que chegamos às diferentes interpretações da obra (construção da 'fábula', da diegese), e que vai além da simples recepção dos dados fornecidos pelo autor. A construção da 'fábula' é tanto pessoal, no que se refere à experiência vivida pelo indivíduo, a forma de ver e interagir com a realidade, as escolhas pessoais, crenças, etc., quanto social, já que está vinculada a uma cultura, pois, como afirma Cândido (Ibidem, p.32), “[...] mesmo quando pensamos ser nós mesmos, somos público, pertencemos a uma massa cujas reações obedecem a condicionamentos do momento e do meio".

Elaborar narrativas, por conseguinte, faz parte e é resultado da interação humana com o mundo a sua volta, mas de fato, o que seria narrar? Geralmente, o termo narração está associado a uma forma de discurso que tem como principal objetivo o relato de um 
evento ou de uma sucessão de eventos, envolvendo ação, personagens, tempo e espaço, e que, juntamente com o foco narrativo, compõem os elementos básicos da composição narrativa, estando presentes em diferentes meios de expressão.

O foco narrativo diz respeito à posição assumida pelo narrador, a perspectiva daquele que conta os fatos. É fator determinante na construção das narrativas e corresponde ao ponto de vista privilegiado por meio do qual flui a narração. Há uma grande variedade de focos narrativos, mas as duas posições básicas são: o foco daquele que está do lado de fora dos episódios narrados ( $3^{\mathrm{a}}$ pessoa) e o de quem se coloca do lado de dentro dos fatos narrados ( $1^{\mathrm{a}}$ pessoa). A partir daí, o foco narrativo pode assumir outras particularidades e, de acordo com a ferramenta de comunicação, é apresentado de forma variada: pela forma da linguagem utilizada, o posicionamento da câmera, o tipo de ilustração, etc.

Assim, a forma como os fatos são apresentados cria efeitos diferentes. É o que ocorre no trecho a seguir retirado do conto Missa do Galo de Machado de Assis (1977, p.17). Na descrição que Nogueira faz de D. Conceição ao observá-la durante uma conversa, temos pormenores físicos da mulher, o que nos faz pensar em closes, revelando pequenos detalhes:

Pouco a pouco, tinha-se inclinado; fincara os cotovelos no mármore da mesa e metera o rosto entre as mãos espalmadas. Não estando abotoadas, as mangas, caíram naturalmente, e eu vi-lhe metade dos braços, muito claros, e menos magros do que se poderiam supor [...] As veias eram tão azuis, que apesar da pouca claridade, podia contá-las do meu lugar. [...] Falava emendando os assuntos, sem saber por que, variando deles ou tornando aos primeiros, e rindo para faze-la sorrir e ver-lhe os dentes que luziam de brancos, todos iguaizinhos. Os olhos dela não eram bem negros, mas escuros; o nariz seco e longo, um tantinho curvo, dava-lhe ao rosto um ar interrogativo. 
No trecho acima, parece estarmos diante de uma “câmera” que focaliza as partes descritas, revelando detalhes na medida em que o rapaz a olha. É o ponto de vista de Nogueira que nos é apresentado (a narração se dá em $1^{\mathrm{a}}$ pessoa). Já no exemplo seguinte, nos vemos diante de uma cena num enquadramento panorâmico ${ }^{10}$. Trata-se de um trecho do conto Os Três Staretzi de Leão Tolstoi (2001, p.145):

De repente, ao claro reflexo da lua nas águas vê qualquer coisa branquear e reluzir. Será uma gaivota ou uma vela branca? Olha com maior atenção: não há dúvida de que é uma barca com uma vela apenas e que segue o navio. Mas como vem depressa! Há pouco estava longe, longe, tão longe, e ei-la já pertinho: e depois é uma barca como nunca se viu, com uma vela que não se parece com vela nenhuma... No entanto, a tal coisa persegue o navio, e o Arcebispo não pode distinguir que coisa é. Será mesmo uma barca, um pássaro, ou um peixe? Parece um homem, mas é grande demais para ser um homem, e depois um homem não seria capaz de andar assim sobre o mar.

O Arcebispo levanta-se, dirige-se ao piloto e diz:

_Olhe só. Que é aquilo?

Mas já vira distintamente os staretzi, que, de barbas brilhando, correm sobre o mar e se aproximam do navio.

O ponto de vista que nos é dado, mesmo sendo a narração efetuada por um narrador onisciente, em $3^{\text {a }}$ pessoa, diferente do exemplo anterior, refere-se ao do Arcebispo, personagem que observa os fatos a partir do navio onde se encontra. Ele avista algo no mar e nós, assim como ele, temos a visão parcial do que está sendo mostrado: não sabemos, inicialmente, do que se trata e as dúvidas do Arcebispo também são as nossas. A focalização nos dá a imagem de algo distanciado, um ponto ao longe. É como se víssemos por uma câmera panorâmica, que mostra a cena à distância a partir do observador, que se encontra no barco. À medida que a descrição continua, temos a sensação de que o objeto se aproxima da câmera, ficando cada vez mais perto, até se

\footnotetext{
${ }^{10}$ Sobre os planos de focalização, baseando-se na gramática cinematográfica, podemos destacar cerca de 8, que vão, numa gradação, desde a panorâmica, mostrando a cena de longe, até o super close, que traz detalhes bem de perto. A utilização dos planos ajuda a construir o espaço, criar conflitos, dar dramaticidade, além de possibilitar muitos outros efeitos na construção da narrativa.
} 
tornar visível: na verdade, tratava-se dos staretzi, velhos sacerdotes que caminhavam sobre as águas em direção ao navio.

A ação é o conjunto de acontecimentos que se realizam num certo tempo e espaço, ou seja, o conteúdo do que se conta na narrativa. Quanto à sua natureza, pode ser a mais variada possível: histórica, mítica, dramática, cotidiana, humorística, heróica, etc.

A ação (que de maneira mais ou menos evidente representa a própria vida) estrutura-se sempre em torno de uma idéia, um valor, um motivo que dá organicidade e interesse ao universo por ela criado. É perseguindo os diferentes 'eixos' da efabulação que encontraremos a visão-de-mundo ali registrada [...]. (COELHO, Ibidem, p.59)

A personagem também integra os elementos da estrutura narrativa, sendo decisiva na mesma, pois, além de ser interdependente à ação (não há ação sem personagens), é uma amplificação das possibilidades humanas e concentra, portanto, o interesse do leitor. Como ressalta Anatol Rosenfeld (1963, p.16), é “[...] a personagem que com mais nitidez torna patente a ficção, e através dela a camada imaginária se adensa e se cristaliza”. Há diversas categorias de personagens (tipo, caráter, individualidade) que serão utilizadas conforme a intenção do autor.

O espaço se relaciona com as circunstâncias que darão realidade e verossimilhança à narração. O meio social ou econômico, o clima, a moda, os objetos de cena, a iluminação, etc., são elementos que integram o espaço. Por fim, o tempo é outro fator vital na estruturação da narrativa. Segundo Coelho (Ibidem, p.65), “a ficção, em qualquer de seus gêneros ou espécies, é uma arte que se desenvolve no tempo”, seja na sua estrutura interna, o encadeamento dos fatos até chegar a um final, seja na fruição, o 
tempo que levamos para apreender a narrativa. Vale lembrar que o tempo não existe por si, mas sim em função de outros elementos, como a ação, a personagem e o espaço.

Tanto na literatura quanto nos quadrinhos, os elementos citados anteriormente se farão presentes, só que apresentados e organizados de maneira própria. Na literatura, a linguagem verbal materializa a narração, ao passo que nos quadrinhos, é a união das linguagens verbal e não-verbal que permite a construção da estrutura narrativa.

\title{
2.2 Literatura: arte de contar estórias
}

A literatura tem sido uma fonte inesgotável de narrativas desde o começo dos tempos e uma das principais formas de propagação dos registros feitos pela humanidade. Vale destacar que nos referimos não só à literatura escrita, mas também à oral, fonte inicial de histórias, mitos e lendas que nos chegam até hoje. De acordo com Coelho (1981, p.4),

\begin{abstract}
Ao estudarmos a história das culturas e o modo pelo qual elas foram transmitidas de geração para geração, verificamos que, na transmissão de seus valores de massa, a literatura foi seu principal veículo. Literatura oral ou Literatura escrita foram as principais formas pelas quais recebemos a herança da Tradição que nos cabe transformar, tal qual outros o fizeram antes de nós, com os valores herdados e por sua vez renovados.
\end{abstract}

Antônio Cândido (2000), citando Madame Stãel, lembra que a literatura é um produto social, pois exprime as condições da civilização em que ocorre, sendo, portanto, coletiva, na medida em que "requer uma certa comunhão de meios expressivos (a 
palavra, a imagem), e mobiliza afinidades profundas que congregam os homens de um lugar e de um momento - para chegar a uma 'comunicação'”. (Idem, ibidem, p.127)

Independente do que se entenda por literatura ${ }^{11}$, a obra literária se constrói pelo uso da linguagem verbal, mas não qualquer tipo de linguagem e sim a literária, com suas especificidades. Como destaca Lotman, (1978, p.55-56),

A literatura fala uma linguagem particular que se sobrepõe à língua natural como sistema secundário [...] Dizer que a literatura possui a sua linguagem que não coincide com a sua língua natural, mas que a ela se sobrepõe - é dizer que a literatura possui um sistema que lhe é próprio de signos e de regras para a sua combinação, que servem para transmitir informações particulares, não transmissíveis por outros meios. [...].

O sistema próprio de signos e regras da linguagem literária de que fala Lotman diz respeito aos elementos que compõe a obra e que englobam desde o conceito de signo, que na obra literária pode assumir diferentes nuances, seu limite, usos, até as regras internas de composição. Assim, o texto literário é constituído de um corpo verbal que se concretiza na obra pela linguagem literária, através de um processo de composição específico (COELHO, Ibidem).

Na literatura, como ressalta Ataíde (1972), há uma série de fatores próprios da linguagem que revelam a característica peculiar assumida por ela nesse meio: entoação, ritmo, melodia, aliteração, verso, tessitura sonora, carga imagética, etc: “O criador de arte

\footnotetext{
${ }^{11}$ Todorov (1973 apud SILVA, 1984) defende que o único denominador comum que liga toda a produção literária é a linguagem. Já Silva (1984, p.34), por sua vez, destaca que há certas regularidades, determinados fatores variantes que definem literatura: "A obra literária é sempre um artefacto, um objeto produzido no espaço e no tempo - um objecto, como escreve Lukács, que se separa do sujeito criador, do sujeito fenomenológico [...], possuindo uma realidade material, uma textura semiótica sem as quais não seriam possíveis nem a leitura, nem o juízo estéticos”.
} 
literária procura dar ênfase à própria linguagem, isto é, o meio empregado é importante [...] A linguagem forma o substrato sobre o qual existirão os constituintes ficcionais" (Idem, Ibidem, p.18).

O uso da linguagem no texto literário permite variadas construções de significação e efeito, e está sujeita a modificações influenciadas pelo contexto de produção, as mudanças sociais, etc. É o que ocorre com a literatura diante das mudanças no processo comunicativo. A esse respeito, Cândido explica:

[...] as formas escritas de expressão entravam em relativa crise, ante a concorrência de meios expressivos novos, ou novamente reequipados para nós [...]. Antes que a consolidação da instrução permitisse consolidar a difusão da literatura literária (por assim dizer), estes veículos possibilitaram, graças à palavra oral, à imagem, ao som (que superam aquilo que no texto escrito são limitações para quem não se enquadrou numa certa tradição), que um número sempre maior de pessoas participassem de maneira mais fácil dessa quota de sonho e de emoção que garantia o prestígio tradicional do livro. (Idem, Ibidem, p.125-126)

Desta forma, o surgimento de novos meios de expressão, que fazem uso da palavra oral, do som, da visualidade, como o cinema, a televisão, e outros influenciou a maneira de elaboração da obra literária. A alteração nas formas de produção e reprodução cultural, sobretudo a partir da invenção da fotografia e do cinema, que modificou a maneira como se olha, percebe e sente o mundo cambiante a nossa volta, estão registradas no texto literário, e está presente nas mudanças na forma de se estruturar os elementos próprios da narrativa (PELLEGRINI, 2003). Sobre a influência da gramática do cinema no texto literário, aliás, podemos citar as palavras do romancista francês 
Claude Simon (1985 apud SILVA, 1990, p.179) ${ }^{12}$ na sua experiência pessoal de elaboração narrativa:

É indubitável que a fotografia e o cinema modificaram radicalmente em cada um de nós o modo como o mundo é apreendido. Acontece, além disso, no que me concerne, e sem dúvida em virtude de um espírito mais sensível ao concreto do que ao abstracto, que não posso escrever os meus romances a não ser precisando constantemente as diversas posições que ocupam no espaço o ou os narradores (campo de visão, distância, mobilidade em relação à cena descrita - ou, se preferir, numa outra linguagem: Ângulo das filmagens, grande plano, plano médio, panorâmica, plano fixo, travelling, etc.).

\subsection{HQs e as múltiplas linguagens}

As HQs revelam em sua constituição, uma linguagem intersignica que se dá através de co-relações, co-referências, analogias, e muitas outras possibilidades interativas. A presença ou não de cores, o tipo de traço, o tamanho das figuras, a disposição da linguagem verbal nos balões (ou a ausência deles), a alternância entre a luz e as sombras, e muitos outros recursos são utilizados na composição dos quadrinhos, que se configuram como um mix de diferentes linguagens e recursos compositivos. E para compreender tal cruzamento de linguagens, faz-se necessário uma “visão semiótica”, que, segundo Lúcia Santaella (1998, p.55):

[...] diz respeito à percepção dos diferentes tipos de linguagem que os diferentes meios veiculam, percepção esta que inclui todas as operações de inter-influências que uma linguagem pode exercer sobre outras. [...] Trata-se, portanto, da captação das ligações (semelhanças e diferenças) existentes entre os diversos tipos de linguagem [...] Disso se pode concluir que o código hegemônico deste século, não está nem na imagem, nem na palavra oral ou escrita, mas nas suas interfaces, sobreposições e intercursos, ou seja, naquilo que sempre foi do domínio da poesia.

\footnotetext{
${ }^{12}$ MORRISSETTE, Bruce. Novel and film. Essays on two genres. Chicago-London, 1985, p.17.
} 
Uma das principais características das HQs é a sua seqüencialidade, ou seja, o uso de imagens sucessivas, colocadas lado a lado, para assim compor uma obra única, daí o termo utilizado por Will Eisner (2005) para defini-las: arte seqüencial. Assim como os desenhos animados, os quadrinhos também se constroem em seqüência, mas diferem daqueles pelo seu aspecto espacial, uma vez que, nos desenhos animados a animação é seqüencial em tempo - cada quadro é projetado no mesmo espaço, que é a tela -, enquanto nos quadrinhos, os quadros ocupam espaços diferentes no papel.

Como explica Cagnin (1975), quando se juntam dois ou mais quadrinhos pode se formar uma série, na qual os quadros permanecem independentes, ou uma seqüência, no caso dos quadros representarem juntos uma unidade significativa. A relação que se estabelece entre cada quadro que compõem as HQs, e que é feita a partir das semelhanças e diferenças, é que dará o aspecto seqüencial e significativo da narrativa gráfico-visual:

Para que duas imagens possam se unir, é necessário que tenham algo em comum. É a identidade. Para que sejam distinguidas, é necessário que sejam diferentes. É a não-identidade [...] A identidade entre as imagens ou figuras que compõem os quadrinhos é uma espécie de fio condutor da narrativa [...] A articulação entre duas ou mais unidades-quadrinho tira a imagem do seu estatuto analógico, da representação pura e simples do objeto e a transforma num elemento do discurso. (CAGNIN, Ibidem, p.157-159)

A seqüencialidade ocorre quando comparamos duas imagens tomadas como um único significante, permitindo assim identificar o que permanece, varia ou continua constante de uma para outra.

Segundo McCloud (2002), as HQs se configuram como imagens pictóricas e outras justapostas em seqüência deliberada. Temos, pois, além dos desenhos, outras “imagens” presentes nos quadrinhos, como a linguagem verbal, que assume aqui um 
caráter pictórico, uma vez que, além da característica imagética inerente a sua própria natureza (uma palavra pode suscitar em nossa mente uma infinidade de imagens), se coloca como recurso visual explorado de diversas maneiras, como, por exemplo, pelo do uso de onomatopéias, caixa alta, cor, tamanho e fonte da letra. A justaposição se dá pelo caráter seqüencial das HQs. Mas não se trata apenas de um ajuntamento de linguagens: na verdade, as relações tecidas entre as várias linguagens nos quadrinhos acabam sendo mais importantes do que as próprias linguagens em si (BARBIERI, 1993).

\subsubsection{A leitura dos intervalos}

O espaço e o tempo são elementos que se imbricam nos quadrinhos. As imagens surgem fixas, dispostas sobre o espaço, revelando todos os elementos que compõem a seqüência (as semelhanças e diferenças), facilitando a comparação e permitindo maior mobilidade de 'leitura', possibilitando, a qualquer momento, voltar aos quadros passados ou avançar para os futuros. Para Cagnin (1975, p.160), a relação entre duas unidadesquadrinhos encaminha a leitura de um lugar para outro, naturalmente, em tempos subseqüentes:

Há uma simbiose entre espaço e tempo de leitura e, por fim, o tempo da leitura passa a se associar ao tempo da narração. A íntima relação entre temporalidade e causalidade induz a outra transformação do tempo em causa e efeito. Os dois processos, comparação e sucessão temporal e espacial, produzem a significação, subordinam os elementos significantes num sintagma e reproduzem a ação . 
O espaço entre cada quadro (vinheta) que compõe as histórias torna-se elemento vital para a seqüencialidade das HQs e revela-se como o local do impulso narrativo, que tanto pode ser espacial quanto temporal ${ }^{13}$. No intervalo entre uma cena e outra é que a história se completa, devido à ação realizada pelo próprio leitor, que transforma os quadros separados num todo indissociável, por meio da conclusão. Como ressalta McCloud (2002, p.33), nas HQs a conclusão cria entre o criador e o leitor uma intimidade, um pacto secreto que só é superado pela palavra escrita: “Os quadros das Histórias fragmentam o tempo e o espaço, oferecendo um ritmo recortado de momentos dissociados. Mas a conclusão nos permite conectar esses momentos e concluir mentalmente uma realidade contínua e unificada”.

A transição entre os quadros nas HQs é, portanto, fator decisivo para garantir a construção da narrativa, tanto no que diz respeito à composição espacial quanto à temporal. A transição pode ocorrer de várias maneiras, desde uma representação de cada pequena mudança nas cenas ou dos movimentos que constroem determinada ação, até longas alterações de tempo, espaço, aspecto, idéias e sentidos. Cada escolha na forma de representar o transcorrer dos quadros resultará em efeitos diferentes (Fig. 9 e 10).

\footnotetext{
${ }^{13}$ Como explica Moya (2002), o corte gráfico gera as elipses preenchidas pela imaginação do leitor, e a transição entre as ilustrações, revela, se fluente, as marcas de um bom narrador.
} 


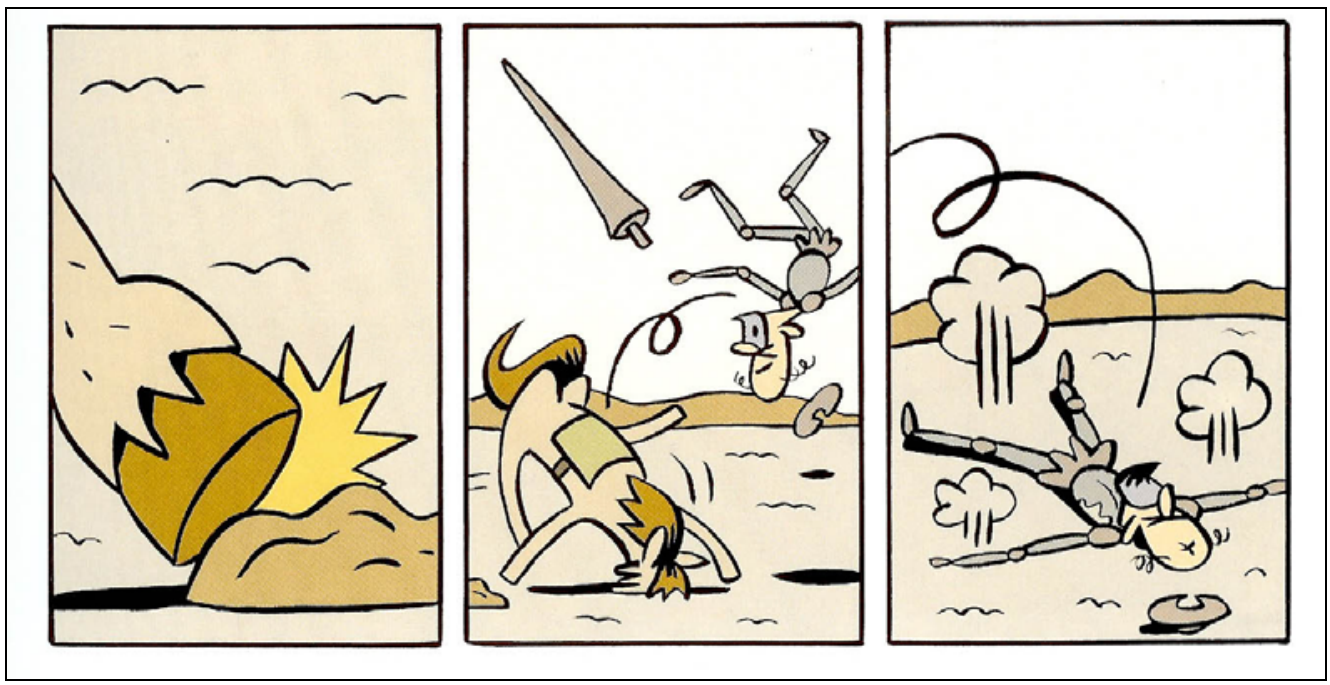

Fig.9 - Na seqüência da HQ Dom Quixote, desenhada por Caco Galhardo, as ilustrações revelam 3 momentos subseqüentes de uma cena ocorrida num mesmo espaço: o tropeço do cavalo na pedra, mostrado por um close da pata do animal, o lançamento de Dom Quixote no ar, reforçado pelas linhas de movimento, que se estendem para o último quadro, quando vemos a personagem caída no chão.

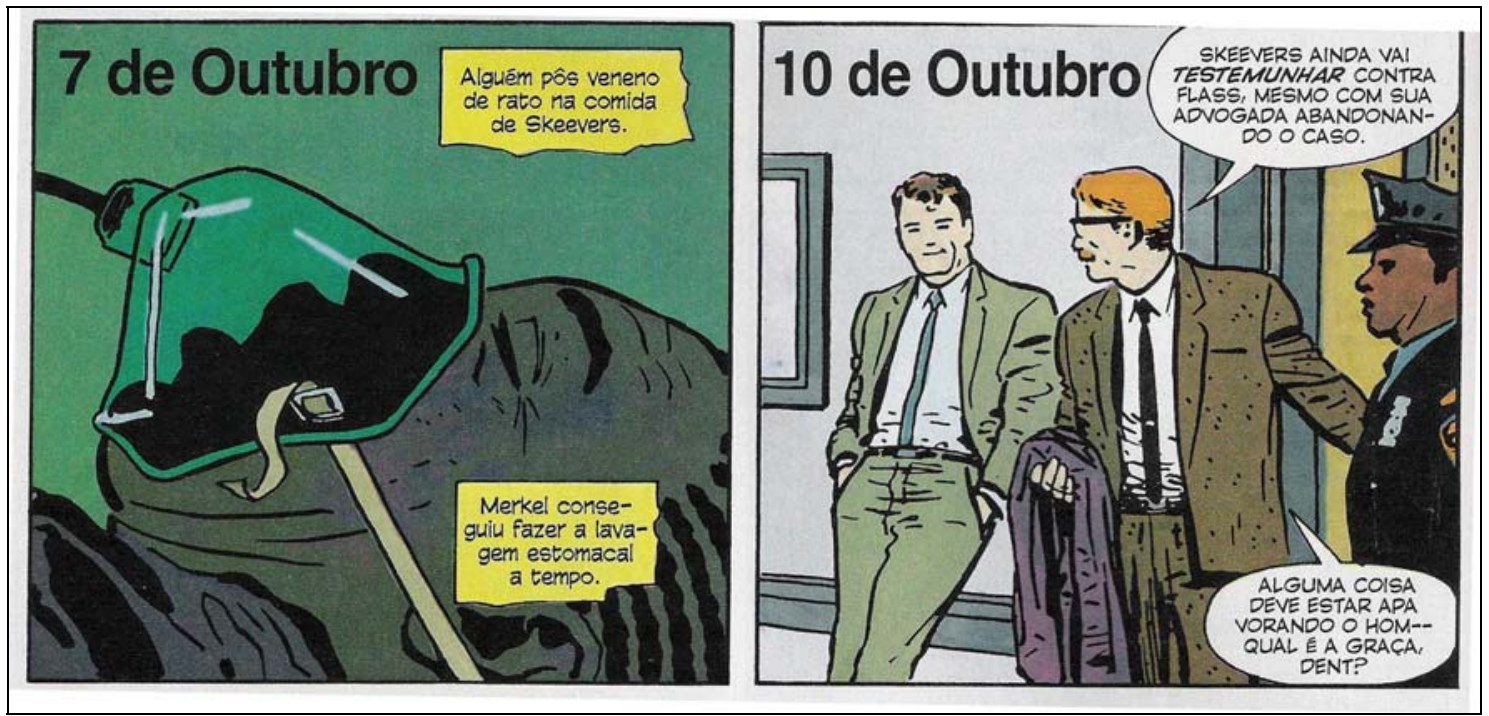

Fig. 10 - A transição entre os quadros também pode revelar saltos temporais, como no caso das cenas da HQ Batman Ano Um, em que os fatos abrangem um período de dias, o que vem indicado pela legenda apontando a data correspondente a cada acontecimento.

Para a realização da mudança entre os quadros, a escolha dos elementos que farão parte da constituição de cada unidade-quadrinho, faz-se necessário o uso da montagem. 
Conforme ressalta Sergei Eisenstein (2002, p.8), “o conceito de montagem está presente em toda a cultura humana. O pensamento humano é montagem e a cultura humana é o resultado de um processo de montagem, em que o passado não desaparece e sim se reincorpora, reinterpretado no presente”. Nas obras de arte como um todo, a montagem se revela como meio eficaz no processo de comunicação.

Contudo, como revela Umberto Eco (2004, p.147), a montagem nos quadrinhos é feita de modo original, pois,

[...] não tende a resolver uma série de enquadramentos imóveis num fluxo contínuo, como no filme, mas realiza uma espécie de continuidade ideal através de uma factual descontinuidade [...] quebra o continuum em poucos elementos essenciais. O leitor a seguir solda esses elementos na imaginação e os vê como continuum ${ }^{14}$.

Outro recurso utilizado na elaboração dos quadrinhos e que contribui para sua eficiência comunicativa no que diz respeito à representação espaço-temporal é a forma e a disposição dos quadros. Para McCLoud (2002), o quadro é o ícone mais importante dos quadrinhos, e funciona como um indicador da divisão do tempo e do espaço. Ao mover os olhos pela página, o leitor também tem a sensação de se mover no tempo. Devido a sua importância, a forma dos quadros ou a maneira como são utilizados influenciará a experiência da leitura. Assim, um quadro sem contorno pode dar mais leveza à leitura, uma imagem que invade outros quadros pode intensificar a dramaticidade de uma cena e outras tantas possibilidades compositivas (Fig. 11).

\footnotetext{
${ }^{14}$ É o que McCloud (Ibidem) define como a 'conclusão', realizada pelo leitor entre cada intervalo dos quadros que compõem as HQs.
} 


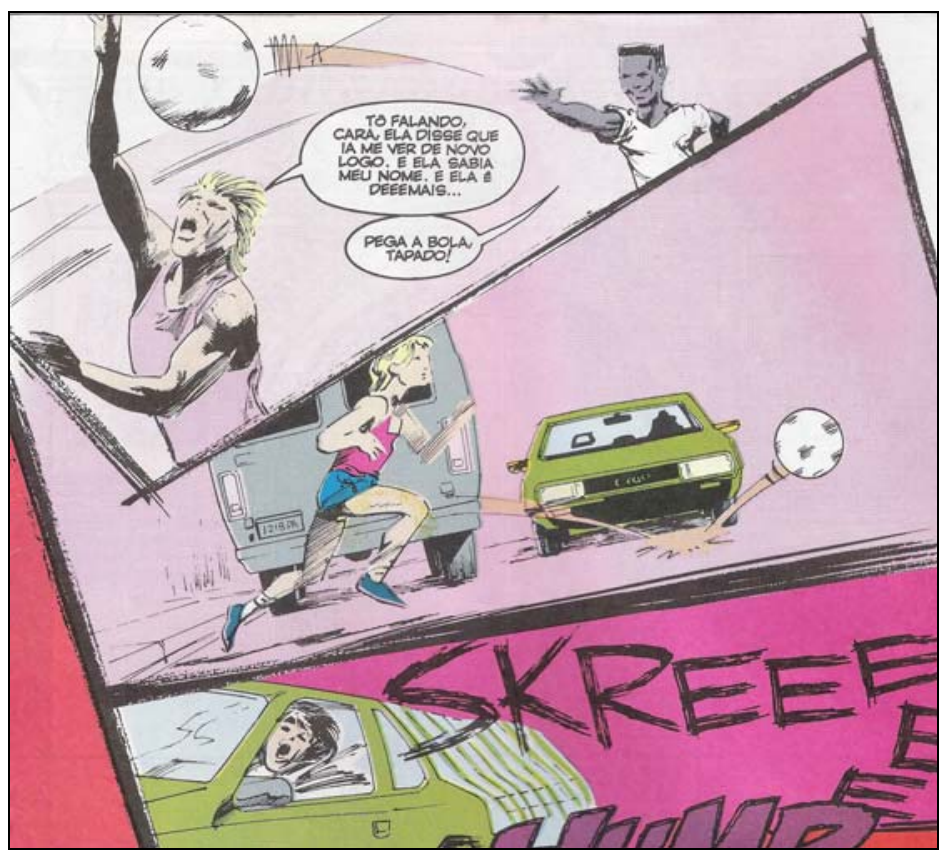

Fig. 11- Na composição dos quadros desenhados para a HQ Sandman no. 8: o som de suas asas, a sobreposição das imagens, a posição inclinada dos quadros e seu contorno irregular, somado ao uso de onomatopéias, ampliam a dramaticidade da seqüência que mostra o atropelamento de uma das personagens (e que resultará em sua morte).

\subsubsection{Personagens e falas}

A representação das personagens nos quadrinhos ocorre principalmente pela caracterização visual. As ilustrações que compõem as narrativas quadrinizadas, aliás, são extremamente variadas, trazendo desde personagens simples até complexas paisagens e cenários detalhados. Os traços podem ir dos caricaturais aos realistas ${ }^{15}$.

\footnotetext{
${ }^{15}$ Para McCloud (2002), por meio do realismo tradicional o desenhista pode representar o mundo externo, enquanto que com o traço cartunizado, o mundo interno: "Quando o cartum é usado [...] a história parece pulsar com vida [...] entretanto [...] se um artista quiser representar a beleza e a complexidade do mundo físico algum tipo de realismo será importante” (Idem, ibidem, p.41).
} 
Eisner (2005) ressalta que, nos quadrinhos, diferente do que ocorre num filme, por exemplo, há pouco espaço e tempo para se desenvolver as personagens, daí o uso, muitas vezes, de certos estereótipos ou caricaturas de determinadas características humanas: o musculoso para representar o herói, os traços simétricos para a beleza, a disformidade para a maldade, etc. (Fig. 12)

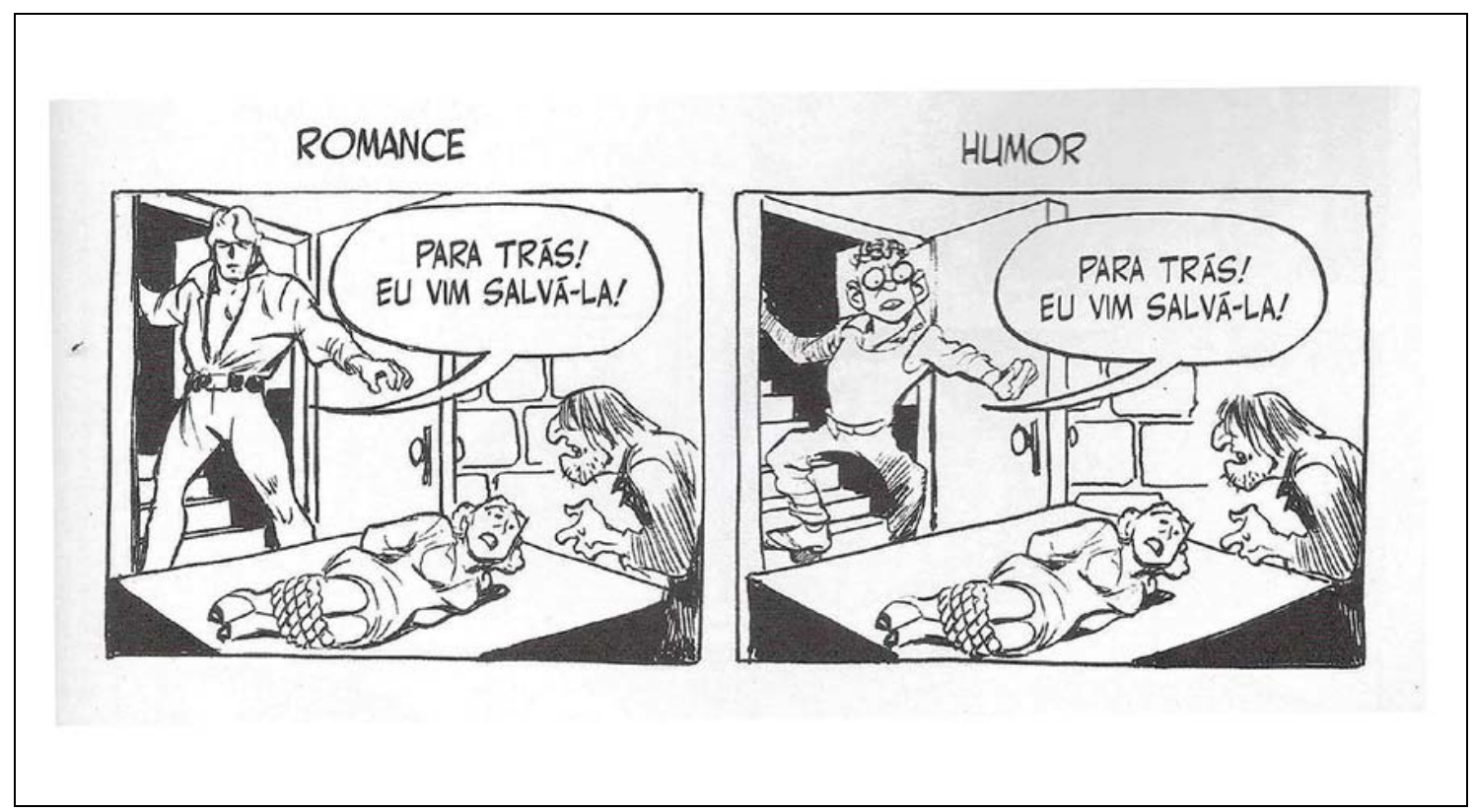

Fig. 12 - No exemplo que Eisner nos dá em seu livro Narrativas Gráficas, podemos perceber como o uso de certos esteriótipos de fato influenciam na composição narrativa. No primeiro quadro, a figura do herói corresponde ao padrão comumente utilizado: forte, traços simétricos, etc. Já quando é utilizada uma figura com características mais caricaturais, o efeito obtido é o do humor.

O balão, onde é inserido a fala ou o pensamento das personagens, é um recurso próprio das histórias em quadrinhos. Tal elemento possibilita maior dinamismo, conforme explica Cagnin (1975, p.121): “o balão, criação original dos quadrinhos [...] é o elemento que indica o diálogo entre as personagens e introduz o discurso direto na sequiência narrativa”. O apêndice (ou rabicho) em forma de flecha que sai do balão e que está voltado para a personagem, marca a relação do texto com a imagem referente, 
indicando quem está falando. Outro aspecto importante do balão é que ele também assume um papel imagético, pois seu formato pode indicar sentimentos, atitudes, e as mais variadas emoções e intenções ${ }^{16}$.

Segundo RENARDT (1981, p.20-21), um dos embriões dos balões já pode ser encontrado nos séculos XII e XIII com o surgimento dos filatérios,

[...] bandeirola que sai da boca do personagem que fala, e na qual se encontram inscritas palavras. Esta bandeirola recebe o nome de phylactère, por alusão a pequenos rolos com o mesmo nome, coberto de extratos da Thora, transportados na fronte pelos grandes padres judeus. É este termo que ainda hoje se aplica por vezes ao balão utilizado na banda desenhada.

A legenda (caixa de informações), aparece ao lado do balão como outro importante elemento narrativo. Normalmente ocupa a parte de cima do quadro que contém a figura, porque é convencionalmente onde se inicia a leitura. Na legenda encontra-se geralmente a fala do narrador, seja ele em primeira ou em terceira pessoa.

É importante destacar que por meio do uso do balão e da legenda, recursos como a voz over e a voz off (informação verbal) ${ }^{17}$, tão utilizados nas obras fílmicas para explicitar a forma de narração/diálogo, também se fazem presentes e ajudam na construção narrativa nos quadrinhos. A utilização da voz over, extradiegética; não audível por quem está na cena, pois sua fonte não participa da mesma (como nos casos das estórias contadas em flash back) é representada pelo uso da legenda. Já a voz off, locução em que a fonte, sujeito falante, não está visível na imagem focalizada, mas participa da cena e é ouvido por quem atua na mesma, surge nos quadrinhos com a

\footnotetext{
${ }^{16}$ Scott McCLoud (ibidem) chama o balão de “ícone sinestésico”, uma vez que ele pode representar muitas sensações/emoções nos quadrinhos.

${ }^{17}$ XAVIER, Ismail. Anotações de aula.
} 
presença do balão sem a representação da personagem que fala. Nesse caso o apêndice do balão se dirige a uma personagem que está fora da imagem mostrada.

Um exemplo da voz over nos quadrinhos é a satirização dos romances policiais noir feita por Luis Fernando Veríssimo e Miguel Paiva em Ed Mort (Fig. 13). Na seqüência, a personagem Ed, numa narração em $1^{\mathrm{a}}$ pessoa e em flashback, conta os fatos que o levaram a iniciar investigações sobre um determinado caso: seu encontro com a Sra. Silva, a mulher fatal, personagem típica dos romances noir.
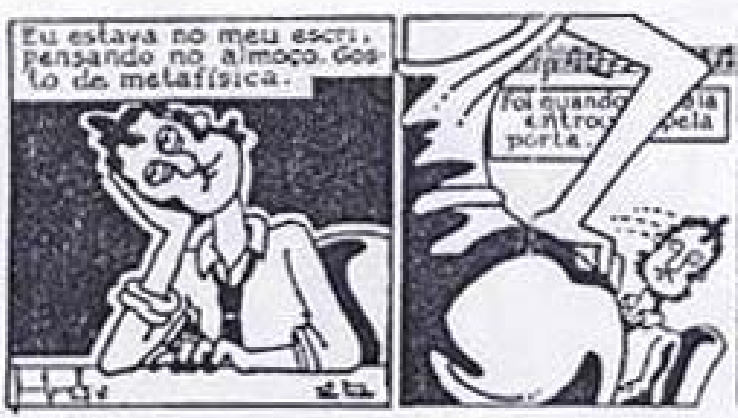

Secrabonita" 50 pos:
so cizer una cousa.

Fich

28

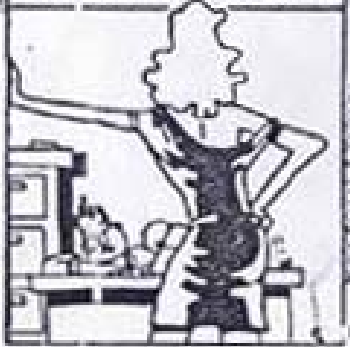

"Mutheriot pera ela. veria diminutsio:

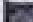

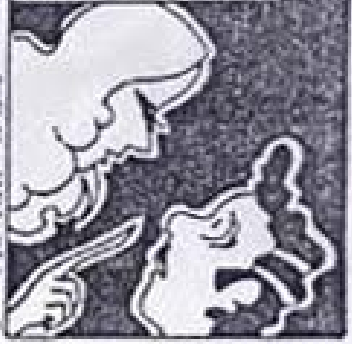

Fig. 13- As falas de Ed ocorrem em outro tempo (presente) que não aquele revelado nas ilustrações (passado). A interação da caixa de legenda com a figura da Sra Silva no $2^{\circ}$ quadro, mostra o quanto os elementos dos quadrinhos podem ser visuais.

Ainda nos quadrinhos de Ed Mort, temos uma amostra de como a voz off pode ser utilizada (Fig. 14). Na ilustração, Ed é ameaçado por um bandido, que não quer a continuidade das investigações. Em toda a seqüência, vemos apenas o rosto em close de Ed, sem a presença de outra personagem em cena. Sua fala é indicada por balões com apêndices voltados para ele, enquanto a fala do bandido é sugerida por balões com apêndices voltados para fora do quadro. É a composição da estória com os demais 
quadros que compõem a página, que traz ao conhecimento do leitor a presença da outra personagem interagindo com Ed.

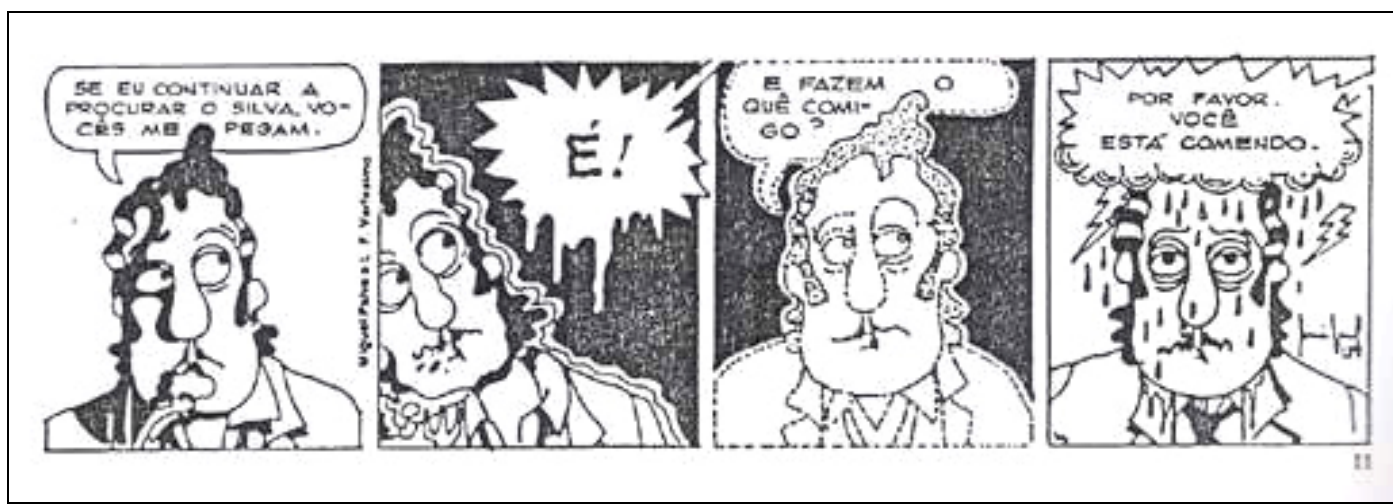

Fig 14 - Os balões se mostram extremamente visuais e ajudam a indicar o que Ed está sentindo no momento. A fala do bandido no segundo quadro apresenta-se num balão de formato recortado e irregular, representando uma fala num tom mais alto, rígido e nervoso, efeito reforçado pelo uso da letra em caixa alta. Já a fala de Ed no penúltimo quadro demonstra seu medo diante da situação, fato denunciado pelo contorno do balão e do desenho que surgem tracejados, o que parece se intensificar no último quadro, devido a presença de gotas e raios saindo do rosto de Ed, elementos tradicionalmente usados para representar tais situações nas HQs.

\subsubsection{Narração em movimento}

Quando entramos em contato com a obra quadrinizada, temos a impressão, em muitos casos, que há de fato movimento na seqüência de imagens. Além dos fatores apontados anteriormente, outros elementos ajudam a criar tal impressão, possibilitando a construção de efeitos dos mais variados, como o drama, o suspense, o humor e muitos outros. A forma de enquadramento (planos fixos, panorâmicas, close-up, etc.), diferentes ângulos de focalização, movimentos de câmera (travelling) e outros, recursos vastamente utilizados pelo cinema, são essenciais para “mover” as personagens no papel, revelar o ponto de vista, construir cenários, dar a ambientação, etc. (Fig 15 e 16) 


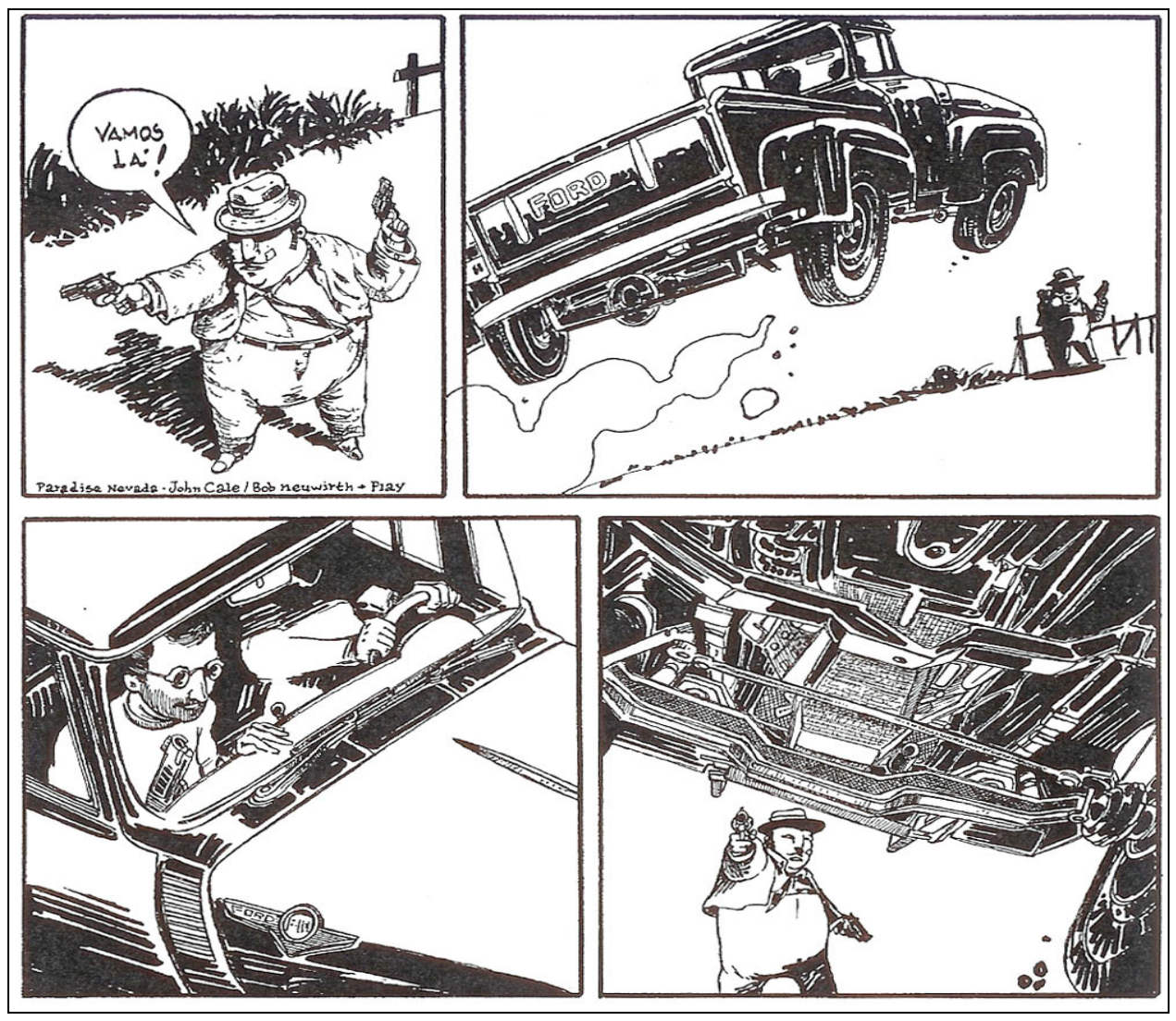

Fig. 15 - Mutarelli, em o Dobro do Cinco, nos revela uma sucessão de cenas com tomadas ousadas e ritmo cinematográfico, em que podemos ver os fatos do alto e até mesmo por baixo do carro em movimento.

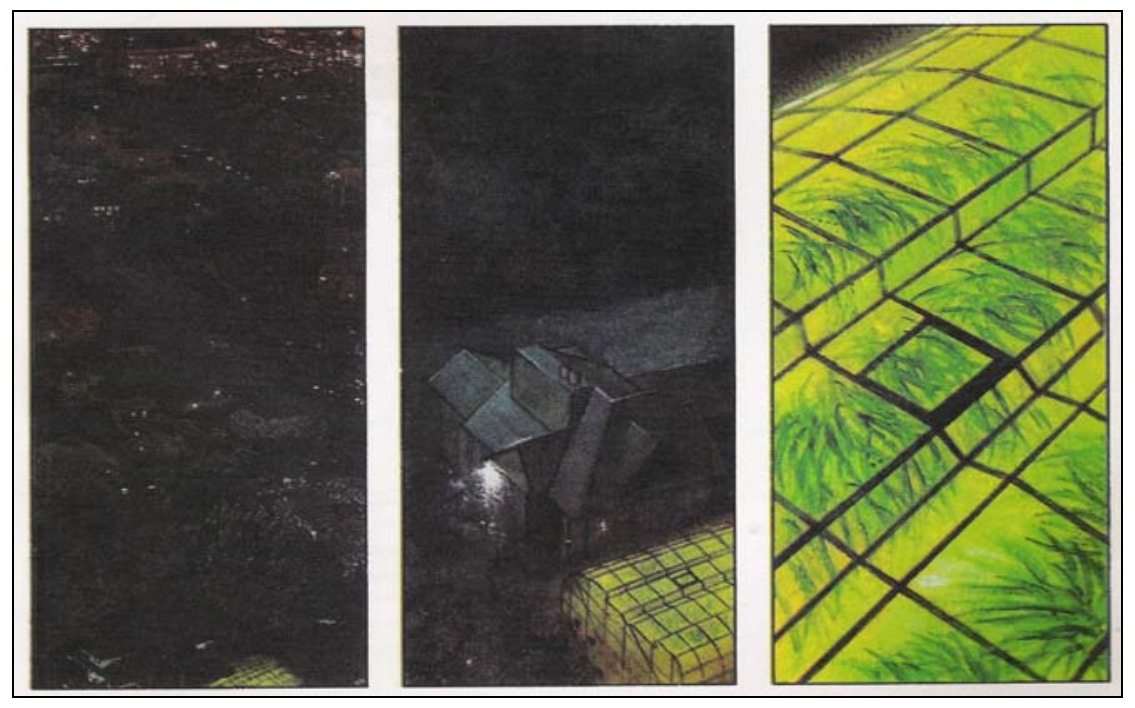

Fig. 16 - Na seqüência dos quadros da HQ Orquídea Negra, temos um exemplo de como o movimento da câmera (travelling) pode ser representado nos quadrinhos. Aqui, a focalização inicia-se pela cidade 
mergulhada na escuridão da noite, sobrevoa uma estufa que se destaca pelo verde na escuridão e, no terceiro quadro, se aproxima do telhado da estufa.

Segundo Gérard Betton (1987), ao discorrer sobre a estética do cinema, o ângulo de uma tomada jamais é gratuito e implica numa escolha, numa postura intelectual e afetiva. Ele explica que há uma infinidade de ângulos, mas geralmente se distinguem: o ângulo normal, em que não há deformação da perspectiva, revelando um ponto de vista horizontal, na altura dos olhos; o ângulo de cima para baixo, plongée, em que as personagens surgem esmagadas no chão, diminuídas, o que pode criar um efeito de sufocamento, angústia, ou dar o clima de certa onisciência do olhar, etc; e o de baixo para cima, contre-plongée, no qual as personagens parecem maiores, superiores, poderosas, podendo suscitar também o pavor, a tragédia, etc. Os ângulos também ajudam a dar a impressão de altura, queda livre, etc. (Fig. 17).

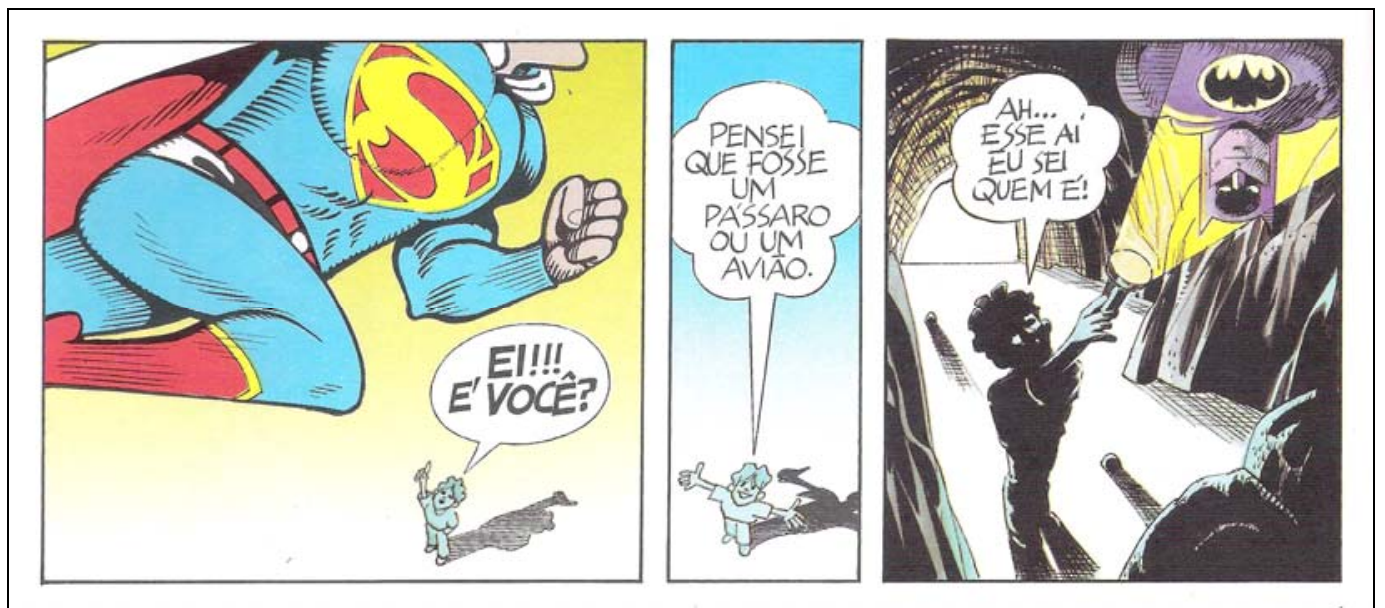

Fig. 17 - Nas ilustrações retiradas do livro O menino quadradinho de Ziraldo, as tomadas aéreas reforçam a idéia de altura: o menino se encontra no chão e vê as demais personagens que se encontram num ponto superior. 
O ponto de vista revelado pelas diferentes formas de composição de planos e ângulos tanto pode ser o do espectador (câmera objetiva), como o de uma personagem (câmera subjetiva). Na seqüência destacada a seguir, temos justamente um exemplo de como a câmera subjetiva pode ser usada nos quadrinhos (Fig. 18). Trata-se de cenas da HQ Orquídea Selvagem de Neil Gaiman e Dave McKean. Nelas, temos a visão da personagem quando criança, um menino de três anos de idade, fato contado em flashback pela personagem já adulta, e nós, como ele, temos a mesma perspectiva de visão. O ângulo das tomadas é de baixo para cima (contre-plongée), do local onde o menino se encontra. Como a criança, vemos tudo a partir de um ponto que se localiza abaixo do campo normal de visão, numa referência à sua baixa estatura. A "câmera" assume o seu ponto de vista, daí não vermos o menino em cena. Sua visão, que inicialmente se localizava sobre um inseto, muda para a conversa entre dois adultos. O fato de o Sr. Linden, no $4^{\circ}$ quadro, entregar uma flor para o menino, dirigindo seu gesto em direção à “câmera”, reforça a idéia de que temos o mesmo ponto de vista da criança-espectadora. 


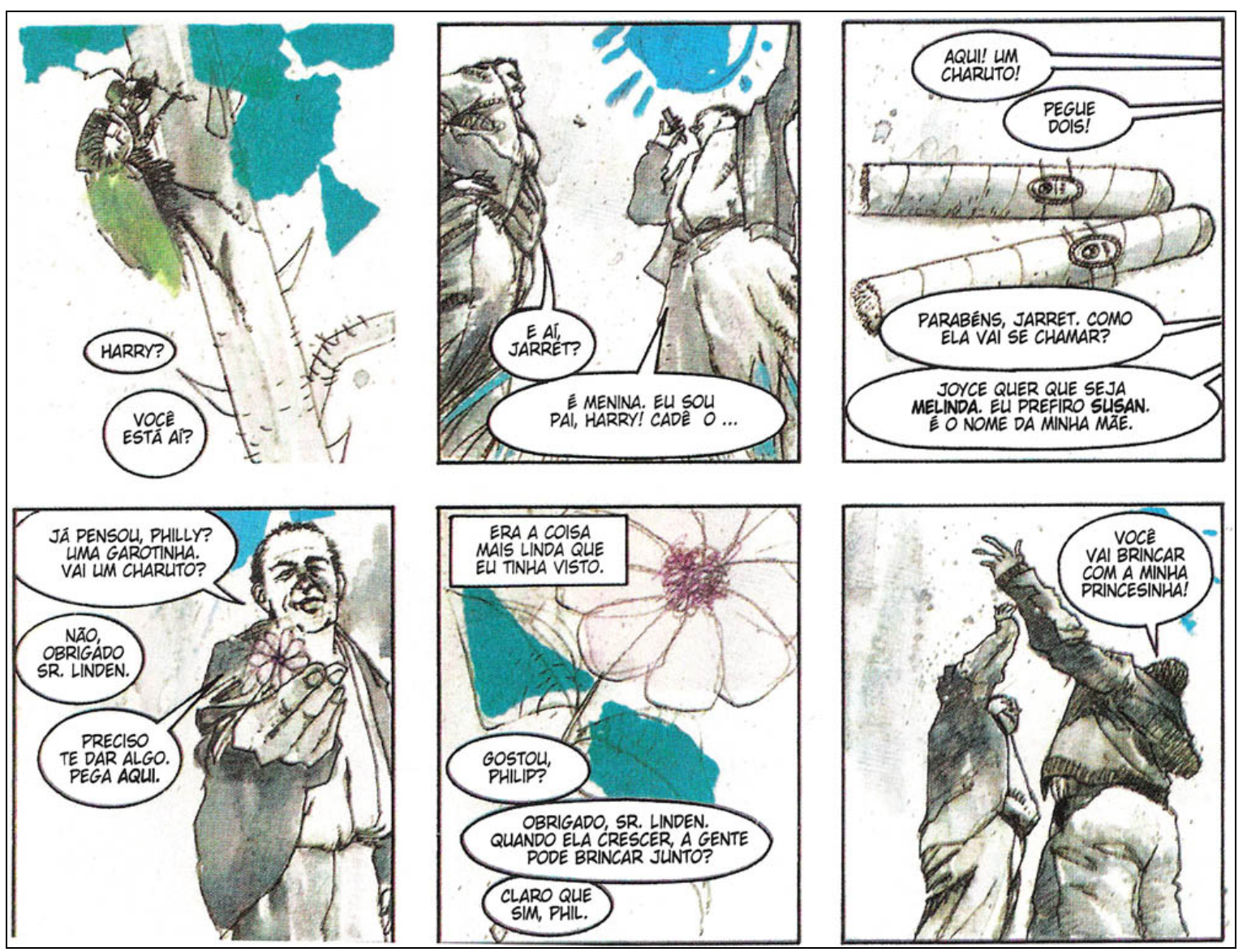

Fig. 18 - Em dois momentos, temos o close de elementos que complementam o sentido da narrativa: o charuto, que revela a comemoração dos adultos em relação ao nascimento de uma criança, e a flor, símbolo daquela que se tornará no futuro a Orquídea Selvagem.

A utilização de linhas na composição das cenas é outro elemento que permite a indicação e acentuação de movimentos, ampliação de sons e outros efeitos narrativos. Em um dos quadros de A turma do Pererê de Ziraldo, o excesso de linhas e as onomatopéias ampliam o efeito de movimento da Onça Galileu, que foge da perseguição do caçador (Fig. 19). 


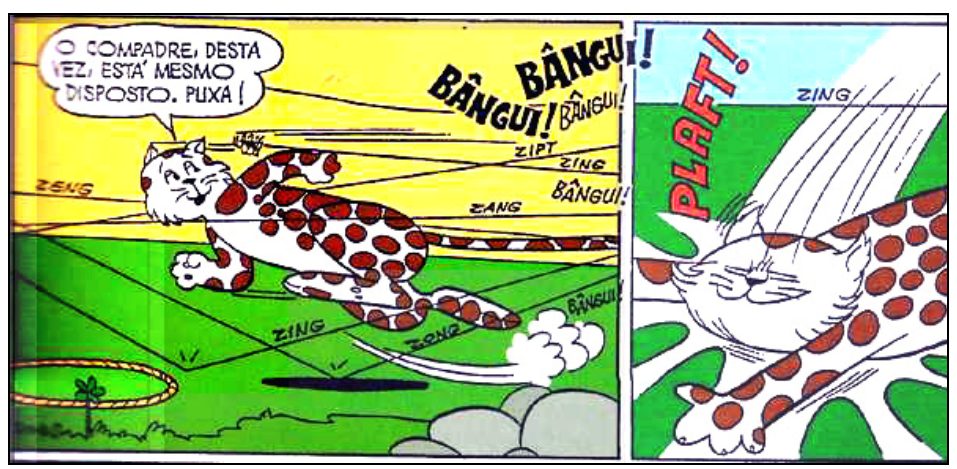

Fig. 19- As linhas e onomatopéias em cena, além de amplificar a sensação de movimento e som, auxiliam na criação do efeito de humor na seqüência.

Elementos como cores ou sua ausência também são importantes para a composição narrativa. A luz, obtida pelo uso de sombras, dos contrastes de claro-escuro, por exemplo, pode auxiliar na delimitação do espaço e da ação, dar profundidade ou volume, criar o clima de suspense, etc. (Fig. 20 e 21)

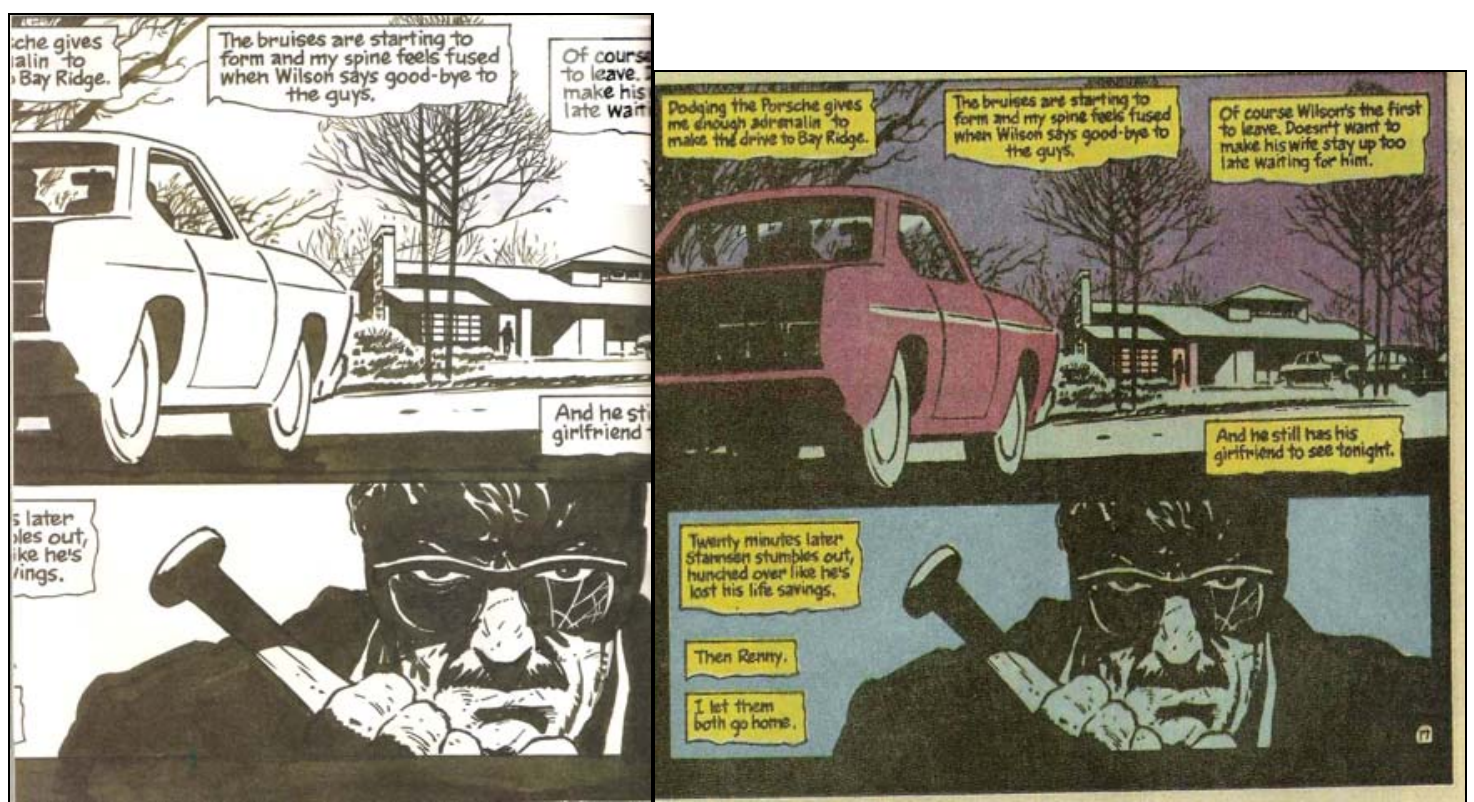

FIG. 20 e 21 - Nos exemplos da HQ Batman Ano Um, temos duas representações de uma mesma seqüência, uma em preto e branco e outra colorida. A ausência de cores na primeira representação em contraste com as cores opacas da segunda, nesse caso, parece conferir mais dramaticidade à cena. 


\section{QUADRINHOS E LITERATURA: RELAÇÕES DIALÓGICAS}

O diálogo entre quadrinhos e literatura é antigo e mesmo em Língua Portuguesa tal relação se dá já há bastante tempo. De acordo com Vergueiro (2005, p.1), as primeiras transposições de obras literárias para a linguagem gráfica nos Estados Unidos ocorreram em outubro de 1941:

[...] o empresário Albert Kanter, da Gilbert Publications, sentiu que os comicbooks $^{18}$ podiam ser utilizados para fins mais nobres que o simples entretenimento, sem, ao mesmo tempo, deixar de propiciar a seus produtores o lucro desejado de qualquer investimento financeiro. Assim, ele teve a idéia de produzir uma revista de histórias em quadrinhos voltada para transmissão dos clássicos da literatura, o que acabou se consubstanciando no título Classics Comics, que em seu primeiro número trazia a quadrinização do romance Os três mosqueteiros, de Alexandre Dumas. Era, então, um trabalho bastante canhestro, sem grandes méritos, mas mesmo assim o sucesso da iniciativa abriu espaço para a continuidade da revista, que posteriormente se aprimorou e se transformou em um dos títulos mais cult da história dos quadrinhos, Classics Illustrated.

No que diz respeito à produção nacional, a primeira obra brasileira a ser adaptada para os quadrinhos foi O Guarani, de José de Alencar, publicado no Diário da Noite, de São Paulo, em 1947, por Jayme Cortez, recém-chegado de Portugal.

No ano seguinte a Editora Brasil América Limitada (EBAL) começou a publicar a versão em português do Classics Illustrated, chamado por aqui de Edição Maravilhosa. Posteriormente, Adolfo Aizen, fundador da EBAL, passou a publicar obras em

\footnotetext{
${ }^{18}$ Comic Books era um novo formato de publicação dos quadrinhos que surgiu nos EUA. Segundo Gonçalo Junior (2004, p.66), esse tipo de publicação: “[...] chegava para aposentar em definitivo o tablóide, predominante entre as publicações do gênero[...] bastava dobrar o tablóide ao meio e grampeá-lo para ter uma revista com o dobro de páginas, mas com custo quase igual [...]”. Outra novidade é que a nova forma de apresentação trazia aventuras completas em quadrinhos, diferente dos episódios seriados semanais dos jornais.
} 
quadrinhos de grandes autores brasileiros da literatura, como Machado de Assis e Jorge Amado dentre outros (VERGUEIRO, Ibidem).

Outras publicações também traziam obras literárias adaptadas para os quadrinhos. Uma delas era O Globo Juvenil, na qual trabalhava Nelson Rodrigues (Fig. 22). Ele, que editava HQs estrangeiras e escrevia outras estórias para a publicação, também fez adaptações de obras clássicas para os quadrinhos: “Com Alceu Penna, em 1938, fez a versão do clássico O Fantasma de Canterville de Oscar Wilde para os quadrinhos. [...] Os dois voltariam a parceria em 1941, quando produziram a versão de O Mágico de Oz, também para o tablóide de Marinho” (GONÇALO JUNIOR, 2004, p.62). 


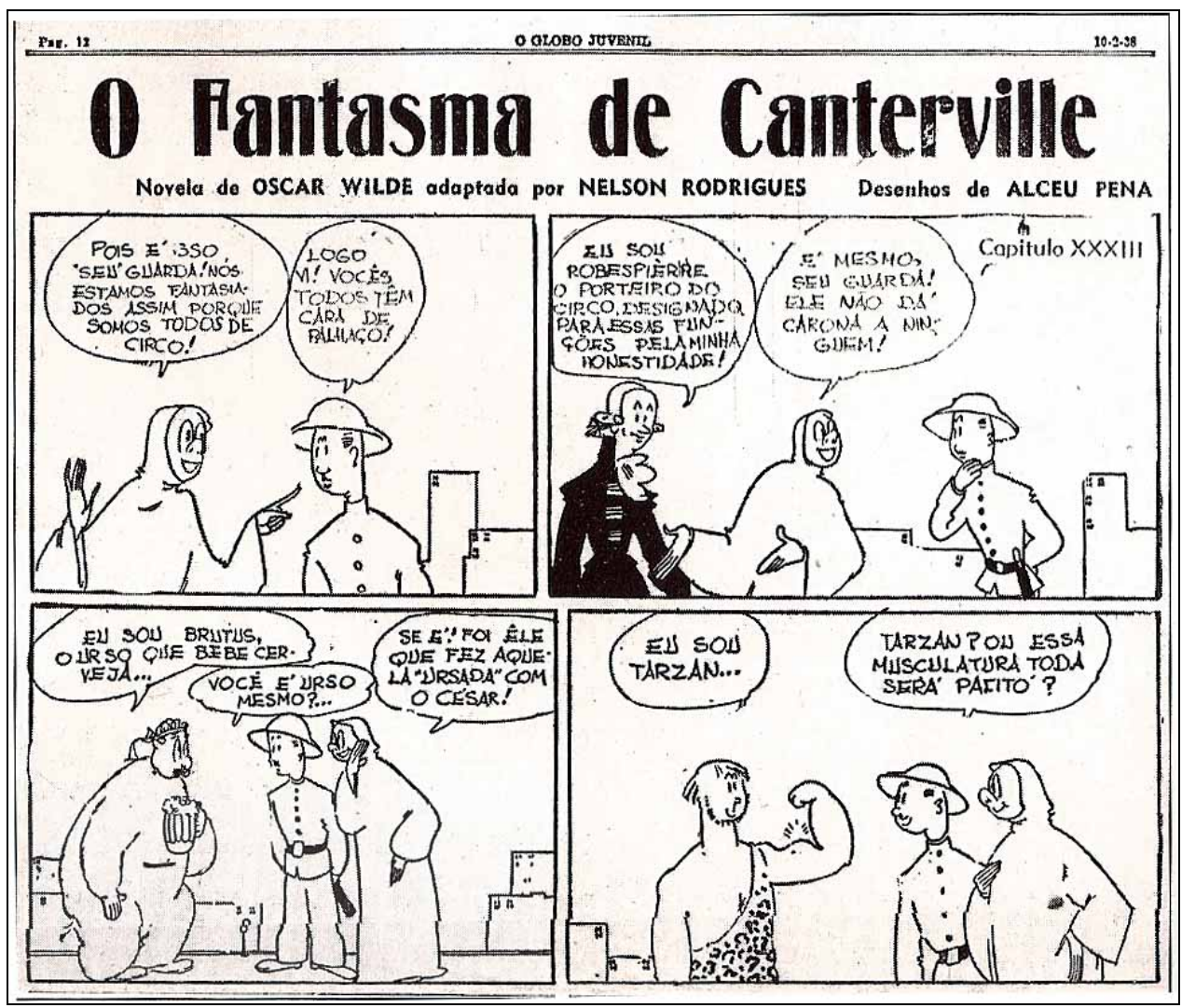

Fig. 22- Na seqüência destacada, temos algumas cenas da adaptação do Fantasma de Canterville feita por Nelson Rodrigues e Alceu Pena.

Nas décadas de 40 e 50 muitas obras foram adaptadas para os quadrinhos, como $A$ pata da gazela de José de Alencar com desenhos de Aylton Thomaz (1955), As três Marias de Rachel de Queiroz, feita por Gutemberg Monteiro (1956-57), Navio Negreiro de Castro Alves, adaptada por Eugenio Colonnese (1957) e muitas outras. Nas décadas de 60 e 70 poucas obras receberam adaptações para os quadrinhos. Durante a década de 70 e início dos anos 80, alguns livros da literatura infantil, como o Sítio do Pica-Pau Amarelo, de Monteiro Lobato, receberam versões quadrinizadas que fizeram sucesso (MOYA, Ibidem). 
O diálogo de obras literárias com os quadrinhos, que se estende até os dias atuais, não se dá de forma homogênea nem numa mesma constância. No Brasil, tal prática tem encontrado um novo impulso nos últimos anos. A inclusão de histórias em quadrinhos nos Parâmetros Curriculares Nacionais (PCNs), como uma alternativa de complementação didática ao ensino, pode, como ressalta Waldomiro Vergueiro (2005), dar novo incentivo à quadrinização de obras literárias no Brasil.

É importante destacar que os quadrinhos enfrentaram ao longo de sua história, diversos preconceitos, uma vez que eram vistos como algo pernicioso. No final da década de 40, uma forte campanha contra os quadrinhos foi iniciada com o lançamento do livro Sedução dos Inocentes, do médico psiquiatra Dr. Frederic Wertham. Ele criticava e destacava a influência das HQs sobre a delinqüência juvenil, o que ampliou o preconceito e a desconfiança quanto à sua leitura. Em conseqüência, foi criado o Comic Codes, que determinava uma série de regras para a produção de quadrinhos, o que representou um freio criativo.

É somente em meados da década de 50 que os autores retomam sua inspiração e, sobretudo, começam a questionar a sociedade sobre aspectos filosóficos e sóciopsicológicos, com histórias como as da Turma do Charlie Brown de Charles Schultz. Na década de 60, os quadrinhos se revitalizam com o movimento underground. Vários artistas se rebelam contra as normas impostas pelos Syndicates e fundam seu próprio movimento. Os super-heróis surgem com aspectos mais psicológicos, se aproximam dos 
humanos, entram em depressão. Aparece com maior destaque as heroínas, certamente como reflexo dos movimentos feministas.

Segundo Moya et al (2002, p.49), no país os quadrinhos também tiveram problemas: “Aqui no Brasil a perseguição não chegou a esses extremos, mas começava uma pressão por parte de professores que acusavam os gibis de deseducativos [sic], de causarem 'preguiça mental' e falarem em 'mau português'”. Após tal campanha, ficou mais difícil o uso das HQs como recurso pedagógico e, ainda hoje, mesmo com seu reconhecimento como importante meio de expressão, ainda há barreiras para sua aceitação. Segundo Vergueiro (2006), os primeiros quadrinhos de caráter educacional publicados na década de 40 nos Estados Unidos apresentavam antologias sobre personagens e acontecimentos históricos e figuras literárias, além das adaptações de clássicos da literatura.

No Brasil, o pioneiro na produção de quadrinhos com objetivo didático são as séries de Julierme de Abreu e Castro. Como explica Flávio Calazans (2004, p.20), "nesses livros de atividades programadas para ensino dirigido, publicados pela IBEP, havia fragmentos ou páginas inteiras de HQs, desde a década de 1960. O primeiro livro, de geografia, é de 1967”. A aceitação dos quadrinhos pelos educadores ocorreu a partir da década de 70, quando se começou a pensar nas HQs como ferramenta para ajudar na alfabetização ou como um modo de incentivar a leitura de livros. Outros materiais também fizeram (e fazem) uso dos quadrinhos para sua comunicação, como manuais, publicações de utilidade pública, folhetos, etc. Nos livros didáticos, por seu lado, houve 
um aumento da presença dos quadrinhos, porém ainda se faz necessário um olhar mais atento para tal expressão artística, que tem muito a contribuir para o processo de ensinoaprendizagem como um todo.

Sendo o quadrinho uma produção estética que, assim como outras, traz em si peculiaridades que a definem como tal, necessita ser aprendida e englobada no processo educacional, pois, como afirma Maria Zilda Cunha (2002, p.25):

Uma perspectiva pedagógica que pretenda compreender a realidade que se constrói na e pela mediação da(s) linguagem(s); a experiência cultural; que almeje a possibilidade de recriação e re nomeação do real, a produção estética tem que, naturalmente, entrar como um elemento constitutivo do acervo de conhecimentos a ser construído pelos educandos.

\subsection{Transposições culturais: absorção e transformação}

A transposição de obras de um meio artístico para outro tem sido uma prática comum em nossos dias. Mike Featherstone, em seu livro O Desmanche da Cultura: Globalização, Pós-modernidade e Identidade (1995), aponta para o fato de que a ampliação da cultura de massa, com a proliferação dos bens e das imagens, é considerada por muitos como o final da separação entre as esferas culturais, e não só em relação às obras, mas também aos grupos de indivíduos. Ao comentar a utilização de um poema de Yeats em uma música de Joni Mitchell, Featherstone (Ibidem, p.19) destaca que esse é um exemplo de “'transposição' [grifo do autor], no qual as formas culturais previamente circunscritas fluem mais e ultrapassam aquilo que, outrora, constituiu uma fronteira estritamente policiada, a fim de produzir combinações e sincretismos inusitados”. 
Um importante aspecto a ser ressaltado quando falamos de transposição entre obras e meios artísticos é o que diz respeito a relação do diálogo com a obra-fonte. A inter-relação entre obras implica numa interferência no texto-base, seja para adequá-lo ao novo suporte, reduzir ou mesmo introduzir novos contextos/elementos no mesmo, dando origem a diferentes obras. Como observa Julia Kristeva (1969 apud MOISÉS, 1990) ${ }^{19}$, todo texto se configura como absorção e transformação de outros textos. Assim, pode-se afirmar que "cada obra surge como uma nova voz (ou um novo conjunto de vozes) que fará soar diferentemente as vozes anteriores, arrancando-lhes novas entonações” (MOISÉS, Ibidem, p.63).

Para compreender como se dá a interação entre obras, é preciso levar em conta tanto o conhecimento prévio do leitor/receptor quanto a forma de recepção no novo meio com o qual a obra-base está dialogando, seja quadrinhos, literatura, cinema, etc.. Cada meio de expressão traz em si elementos próprios que o caracterizam e a relação do leitor/receptor se dará de forma diferenciada, levando-se em conta tais elementos. A esse respeito, Lotman (1978, p.62) explica:

Para que um ato de comunicação artística em geral exista, é necessário que o código do autor e o código do leitor formem conjunto de elementos estruturais que se cruzem [...], por exemplo, que o leitor compreenda a língua natural em que o texto está escrito.

É necessário que o receptor compreenda não só o código específico do autor, mas o próprio código da arte com a qual está interagindo: se for um texto literário, além de compreender a língua natural em que foi produzido, também conhecer o sistema literário,

19 KRISTEVA, Julia. "le mot, le dialogue, le roman". Semiotike: Recherche pour une Sémanalyse. Paris: Seuil, 1969. 
o código subjacente a tal sistema, os mecanismos envolvidos no processo de produção; se for uma história em quadrinhos, compreender o processo de interação entre as linguagens verbal e não-verbal que ocorre nas HQs, bem como outros recursos utilizados; se for um filme, entender e reconhecer elementos como o uso da imagem em movimento, do som, etc.

Aliás, como ressalta Moacy Cirne (1972, p.93), “transpor uma obra de uma dada prática estética para outra prática estética implica assumir semiologicamente os signos de uma nova linguagem”. No caso específico desse estudo, não importa se a obra quadrinizada ou transformada em literatura é fiel à obra-base. O que se coloca é se como discurso quadrinizado ou literário a obra corresponde às expectativas. Caso contrário, o que acontece é uma violentação, não da obra-base, mas da própria estrutura narrativa da nova obra criada a partir daquela, em outro meio expressivo, que surge a partir da mobilização dos recursos disponíveis no outro meio.

Quando uma obra elaborada a partir de outra, em suporte diferente, não assume os signos e códigos do novo meio em que está sendo produzida, numa tentativa de manter a estrutura narrativa da obra-base, teremos uma nova obra que não corresponde às possibilidades comunicativas do meio em que está sendo veiculada. Corresponder às expectativas significa, portanto, que a obra produzida em diferentes meios, traga em si as marcas desse meio, revelando os elementos narrativos produzidos a partir da arregimentação dos recursos do novo suporte em que foi produzida. Na literatura, a linguagem verbal concretiza na narrativa os elementos de composição (ação, 
personagens, etc.). Nos quadrinhos, por sua vez, é a integração entre as linguagens verbal e não-verbal que materializam tais elementos, fazendo uso para tanto, de diversos recursos como os balões, legendas, forma das vinhetas, maneira de disposição no espaço (papel), etc.

Pedro Barbosa (2002, p.26-27), ao comentar o intercâmbio que ocorre entre as diversas artes, explica que,

[...] na transposição semiótica não é apenas o código que varia, mas a própria natureza dos sinais utilizados (na adaptação de um romance ao cinema, por exemplo, convertemos uma mensagem expressa originariamente em signos lingüísticos numa outra constituída por imagens audiovisuais). [...] Sem dúvida que quanto mais próximos estiverem os sistemas semióticos a converter mais fácil se torna uma transposição e mais fiel ela pode ser ao modelo original. [...] Isso explica que sejam tão freqüentes as transposições de obras narrativas entre discursos estéticos que incluam a dimensão temporal na estrutura da sua mensagem [...] já que a narratividade (a criação de uma 'história') assenta sobre a seriação de acontecimentos no tempo.

No caso dos quadrinhos e da literatura, a transposição é mais próxima, visto que, além dos suportes físicos que veiculam tais manifestações artísticas se aproximarem, levando-se em conta que estamos nos referindo especificamente às obras tanto literárias quanto quadrinizadas produzidas no suporte papel, ou seja, no livro, no álbum, na revista, etc., ambas trabalham com a narrativa, fazendo uso de elementos que fazem parte do código básico da narração (tempo, espaço, ação, etc.).

O resultado dessa intercomunicação, por sua vez, pode ser variado. Há desde adaptações que reproduzem na integra a obra original até aquelas que propõem novas formas de diálogo. De certo que a maneira de se relacionar com o texto-base obedece a determinados objetivos. Desta forma, teremos obras que buscam auxiliar a leitura das 
originais, fazendo a mediação entre essas e o leitor, outras que procuram propor novas leituras da obra base e assim por diante.

Seguindo a definição que Gerard Genette (1982 apud MELLO, 2006) ${ }^{20}$ dá de hipertexto, uma das categorias do que ele define como transtextualidade, que engloba de uma forma geral toda forma de diálogo de um texto com outros textos, teremos que tal relação se refere a qualquer texto que "derive” de um outro, seja por transformação simples seja por imitação. Os textos/obras originados dessa maneira podem se apresentar sob a forma de paródia, que retoma um texto apresentando-o com diferentes intenções, sátira, ridicularização de um determinado tema com efeito cômico ou não, pastiche, imitação de uma determinada obra em que o autor assume o estilo de outro (a mesma forma de "contar"), paráfrase, que seria o recontar um texto/obra com outras palavras, sem, contudo, modificá-lo, plágio, apropriação de uma obra ou trechos da mesma sem reconhecer a fonte/autoria, etc. Assim, estabelecendo combinações diversas, o diálogo entre os meios pode originar desde adaptações pastiche, que procuram imitar as originais em outros suportes, adaptações criativas, que adaptam a obra-base acrescentando-lhe elementos que inovam sua leitura, re-criações paródicas, que reconstroem a obra numa chave cômica e muito mais.

Outro aspecto importante que precisamos levar em conta quando estudamos a relação entre obras são as tradições, os cânones estabelecidos em determinada cultura, o que nesse estudo em especial se torna elemento chave para compreendermos os diálogos

\footnotetext{
${ }^{20}$ GENETTE, Gérard. Palimpsestes. Paris: Seuil, 1982.
} 
entre o literário e os quadrinhos. O termo cânone, derivado da palavra grega kanon (um tipo de vara que servia como instrumento de medida) se refere a um conjunto de regras ou modelos sobre determinado assunto. Nas artes, o termo se aplica a um conjunto de obras tidas como oficiais e genuínas. O cânone moderno, como explica Perrone-Moisés (1998 apud JACOMEL 2008) ${ }^{21}$ pode ser explicado a partir da teoria de Kant, partindo-se do princípio de consentimento: durante um determinado período, as obras e escritores que obtiveram um maior assentimento tornam-se modelares. Também há, integralizado no conceito de cânone, o pedagógico: “A preocupação com a função pedagógica do cânone literário toma corpo no século $\mathrm{XX}$, no sentido de querer fornecer leituras formadoras ao currículo dos jovens e prepara-los para 'reconhecer' [grifo do autor] as obras de qualidade estética”. (JACOMEL, 2008, p.5)

No que diz respeito à existência dos cânones, há quem os considere excludentes, na medida em que deixam de fora todos os que não correspondam à ideologia dominante. Por outro lado, há aqueles que defendem sua existência como forma de selecionar as obras/autores que podem ensinar mais seletivamente os leitores devido à sua qualidade estética (BLOOM, 2001). Independente da polêmica em relação à aceitação dos cânones, para esse estudo consideraremos sua presença nas artes (tanto literária quando a dos quadrinhos) como geradora de matrizes que serão, por via dos diálogos propostos, questionados (ou não) de acordo com a forma como se dá a intercomunicação entre as obras.

\footnotetext{
${ }^{21}$ PERRONE-MOISÉS, L. Altas Literaturas: Escolha e Valor na Obra Crítica de Escritores Modernos. São Paulo: Companhia da Letras, 1998.
} 
Vejamos nos próximos itens, como se dá a transposição de obras literárias para os quadrinhos e como os recursos estéticos das HQs podem propor novas leituras de obras tradicionais, obtendo assim resultados dos mais variados. Sobre as relações apresentadas a seguir, vale destacar que poderemos encontrar, numa mesma obra, características de uma ou mais categorias das levantadas. O critério para a classificação das obras em determinada categorização é a predominância de certos aspectos que as aproximam mais de uma forma de interação do que outras. 


\subsection{Da literatura para os quadrinhos}

"Nessa sociedade, sedenta de novos conceitos, métodos e técnicas movidas pelo poder econômico, começa-se a fazer adaptações de clássicos da literatura como 'Cinderela', 'As mil e uma noites' e várias outras histórias que tiveram a sua origem em classes intelectualizadas ou da sabedoria popular”.

José Nicolau Gregorin Filho

Diversas obras literárias foram e são adaptadas para os quadrinhos ou servem de base para a elaboração de diferentes obras nas HQs. Como bem ressalta Pedro Barbosa (2002, p.25), é a partir de adaptações que muitas pessoas passam a conhecer as obras literárias:

É em banda desenhada ou em seriados televisivos que os jovens de hoje tomam contato com o universo romanesco de 'Os Miseráveis' de Vítor Hugo e é no cinema que os cidadãos apressados ficam a conhecer a monumental história da 'Guerra e Paz' de Leão Tolstoi [...] E temos de reconhecer que em nenhum outro tempo, como o nosso, este fenômeno da adaptação se tornou tão freqüente e tão característico.

Mas de fato, o que acontece quando uma obra literária é adaptada ou estabelece algum outro tipo de diálogo com as HQs? Temos o texto original, na maioria das vezes rico em construções lingüísticas e imagéticas que, ao passar para o suporte quadrinhos, integra uma nova composição narrativa, composta das linguagens verbal e não-verbal numa relação única. 
Quando observamos adaptações-diálogos de textos literários para os quadrinhos, é possível identificar uma gradação, em que há desde obras que remetem diretamente ao texto-base até aquelas que fazem da literatura um mote para a elaboração de novos enredos. Assim, teremos: HQs mais próximas da literatura, remetendo, muitas vezes, ao texto ilustrado, obras que propõe novas construções narrativas, seja pela apresentação de diferentes propostas na utilização dos recursos dos quadrinhos, seja pela inserção de novos aspectos no enredo original e, por fim, HQs que se utilizam de elementos da literatura para construir outras obras.

\subsubsection{Mantendo o texto-base}

Algumas HQs ao adaptar obras da literatura procuram manter o texto-base com poucas ou nenhuma alteração, trazendo assim as marcas da obra original em sua estrutura. Tratam-se do que poderíamos chamar de adaptações pastiche, em que há uma "imitação” da obra original só que feita por meio de outros elementos. Por não se distanciar do original produzido na literatura, algumas dessas obras não assumem integralmente os recursos narrativos do novo meio no qual estão sendo veiculadas: os quadrinhos. Geralmente, a integração entre as linguagens se mostra condicionada ao enredo que lhe dá origem, daí a sensação, em determinadas obras, de estarmos diante de um texto ilustrado, em que a linguagem não-verbal surge apenas para acompanhar e ilustrar a verbal, não acrescentando novos elementos à mesma, com um caráter, por vezes, mais acadêmico. Há, contudo, o uso da montagem que vai revelar a escolha dos momentos a serem quadrinizados e significa, 
por sua vez, uma interferência no texto-base, já que há uma seleção pessoal para se definir tais escolhas.

Assim, buscando representar o texto-base num novo suporte, mas resguardando suas características originais (desde o enredo até a linguagem), a obra quadrinizada se mostra muito próxima à literária, sem que haja a inserção de elementos que possam modificar e/ou interferir na obra original. Os elementos dos quadrinhos são utilizados de maneira mais subordinada e complementar ao texto-base, e é a linguagem verbal quem conduz a narração. A linguagem não-verbal atua em função da linguagem verbal, procurando ilustrar da melhor maneira o que ela expressa.

Muitas adaptações de textos literários para os quadrinhos procuram manter não só o enredo, mas a própria forma de construção narrativa da literatura, cuja principal característica é o uso da linguagem. Daí o uso de longos trechos da obra original, com extensas legendas trazendo a linguagem verbal.

Desde o início das adaptações literárias para as HQs até os dias de hoje, tem sido essa a forma escolhida por muitos autores para adaptar obras da literatura, numa referência direta ao aspecto didatizante do resultado, por tornar mais acessível para muitos a leitura dos clássicos, uma vez que vêm mediados pela visualidade inerente aos quadrinhos aspecto ao qual a maioria das pessoas já se mostra acostumada/adaptada, pois a sociedade moderna se fundamenta, principalmente na visualidade, ao passo que a literatura, se mostra distante daqueles que, como explica Cândido (cf. cit. p.44), não se enquadraram em 
determinada tradição, não estando familiarizados com o código narrativo próprio do texto literário.

Destaquemos a seguir duas obras quadrinizadas, que adaptam clássicos da literatura e que foram produzidas em épocas diferentes (A Moreninha, de 1953, e Gaetaninho, feita em 2006), cuja característica em comum é a tentativa de adaptar obras literárias procurando preservar ao máximo o enredo original.

\section{a)- A Moreninha, um gancho para a literatura}

A Moreninha, primeiro romance romântico brasileiro, foi escrito em 1844 por Joaquim Manuel de Macedo, e tornou-se um dos nossos "clássicos”, destinado à "leitura para as moças”. Sua adaptação para os quadrinhos foi feita por Gutemberg Monteiro em 1953, época em que havia uma grande campanha contra as histórias em quadrinhos. Para dar uma resposta aos críticos, Adolf Aizen resolveu investir na adaptação de clássicos da literatura para as HQs, objetivando mostrar que elas também serviam para propagar a cultura entre os jovens. Nos anos 1950, não por acaso, coincidindo com a chegada da Televisão entre nós, no mercado editorial começam a aparecer obras literárias adaptadas para os quadrinhos. O principal alvo era o público escolar e as primeiras obras quadrinizadas foram “clássicos” que constavam dos currículos oficiais. Muitas obras produzidas nesse período traziam a advertência de que aquele era apenas um 'aperitivo', e caso os leitores quisessem mais, deveriam ler a obra original. Essa, aliás, tem sido uma das 
formas como a adaptação/diálogo entre a literatura e o quadrinho é visto até hoje por muitos: como algo menor e complementar. A adaptação de A Moreninha traz em si uma série de marcas que caracterizam sua função educativa, revelando-se um gancho para a literatura.

Seguindo uma trama amorosa ingênua e com lances imprevistos, A Moreninha segue a estrutura do romance-folhetim, tal como se tornara moda no nosso romance do século XIX. Sobre o folhetim, Cândido (2000, p.30) comenta:

"Com a invenção do folhetim romanesco por Gustave Planche na França, no decênio de 1820, houve uma alteração não só nos personagens, mas no estilo e técnica narrativa. É o clássico 'romance de folhetim', com linguagem acessível, temas vibrantes, suspensões para nutrir a expectativa, diálogo abundante com réplicas breves.”

Assim, seguindo a estrutura de um folhetim, com capítulos que acabam sempre com um suspense, o romance A Moreninha aborda, em seu enredo, uma história de amor vivida por Carolina, a Moreninha do título, e Augusto, um estudante de medicina que descobre, a certa altura, que sua amada atual era uma antiga paixão de infância, a quem ele havia feito uma promessa de amor eterno. As personagens que vivem a trama desenvolvida no romance se revelam ingênuas e sentimentais, e a paisagem que serve de cenário à trama é mostrada de forma convencional e já superada em nosso tempo.

A quadrinização de A Moreninha nessa obra segue um esquema de pastiche, na medida em que procura reproduzir ao máximo possível a obra literária. Nos quadrinhos encontramos o mesmo tom folhetinesco apresentado no romance, com a representação das personagens e do cenário, tanto pela linguagem verbal quanto pela não verbal, de forma 
convencional. A montagem e a escolha dos momentos a serem quadrinizados são feitos de forma a não se perder eventos importantes, permitindo assim a compreensão da trama como um todo.

A busca pela transposição mais próxima do texto-base já pode ser percebida no início da obra. A adaptação, feita em preto e branco, traz nas ilustrações a mesma informação (na medida do possível) que é apresentada nas legendas, atuando de forma ilustrativa à linguagem verbal. Assim, nos primeiro quadro da estória, temos a descrição da Moreninha (Fig.23). Aqui, a linguagem não-verbal expressa o que vem descrito na legenda que a acompanha e a linguagem verbal, por sua vez, acaba por fornecer mais informações do que a ilustração, que se restringe às características físicas e espaciais da descrição, não dando conta de representar os traços psicológicos referenciados textualmente: irrequieta, alegre, irreverente, etc. 


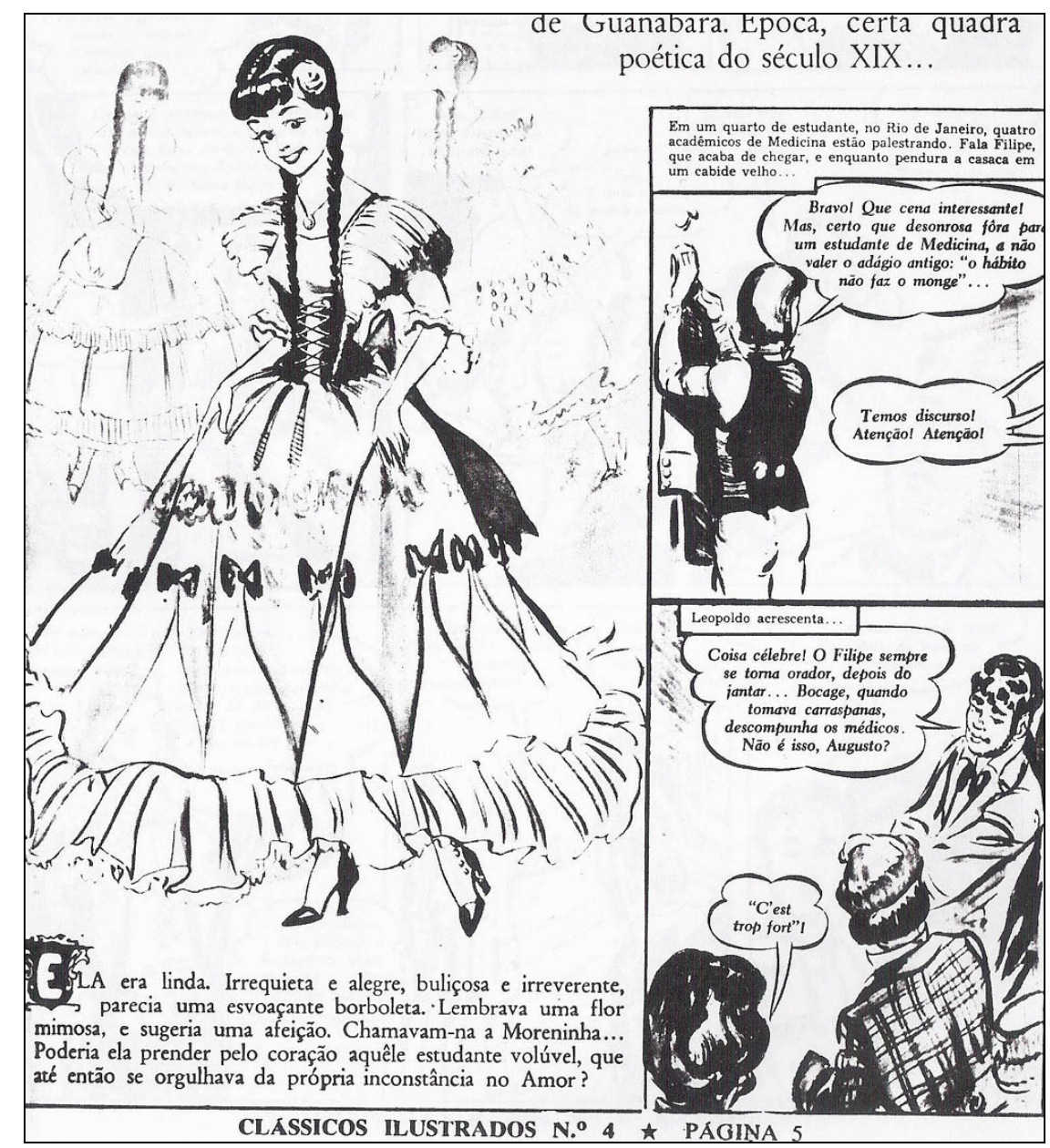

23 - A linguagem verbal acrescenta mais elementos à figura da Moreninha do que a linguagem não-verbal. Nas vinhetas ao lado, somos apresentados a outras personagens, identificadas pela legenda.

A tentativa em reproduzir a obra original não se restringe apenas as linguagens verbal e não-verbal. Também há uma busca por se manter o tom e o estilo folhetinesco da obra-base. Daí o uso de muitos diálogos, com réplicas curtas, representados nos quadrinhos pelo uso abundante dos balões. De certo que também há trechos em que o uso de legendas é igualmente bastante explorado, na medida em que se procura reproduzir a fala do narrador onisciente (Figs.24 e 25). 


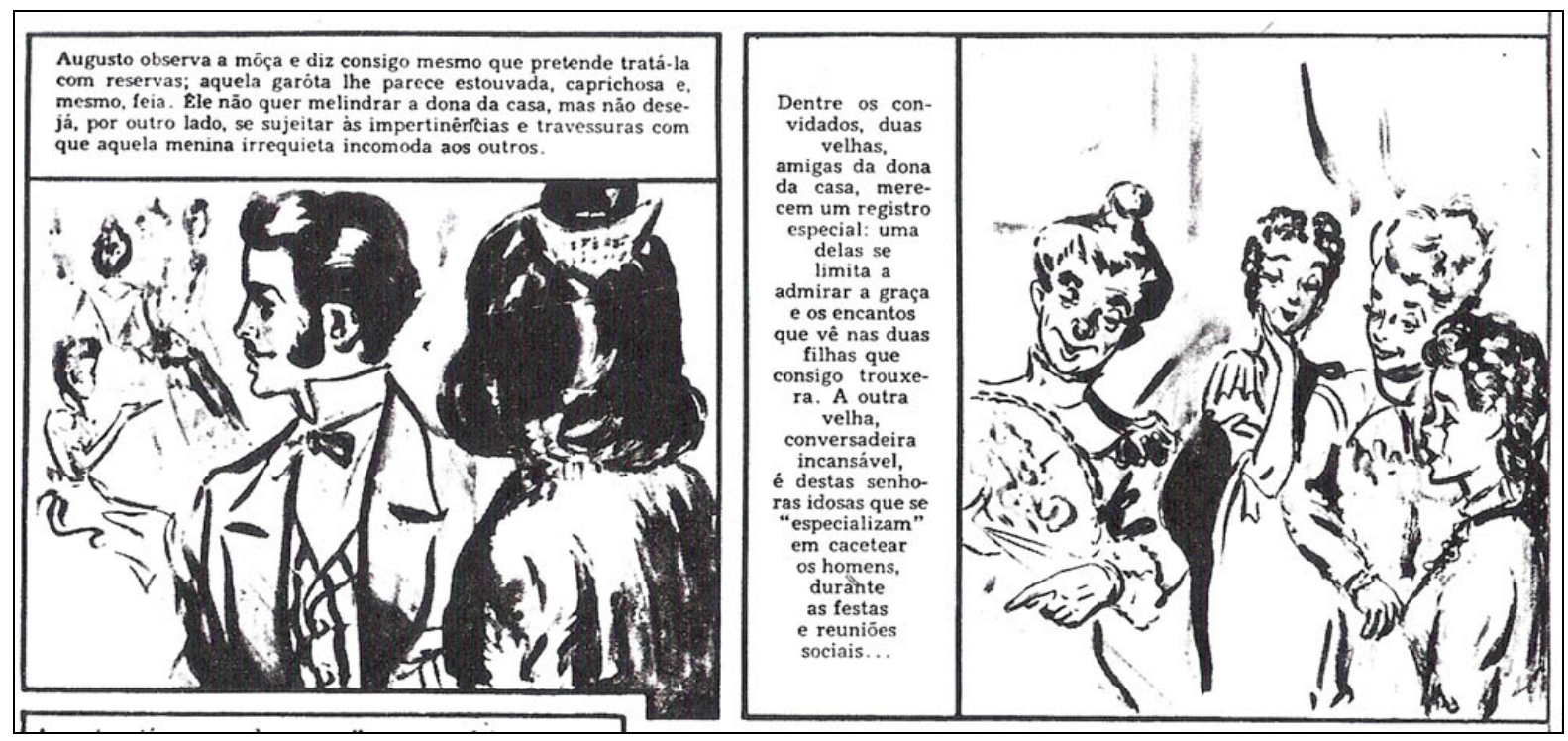

Fig. 24 - Na seqüência em que o narrador onisciente narra fatos do enredo, temos o uso das legendas.
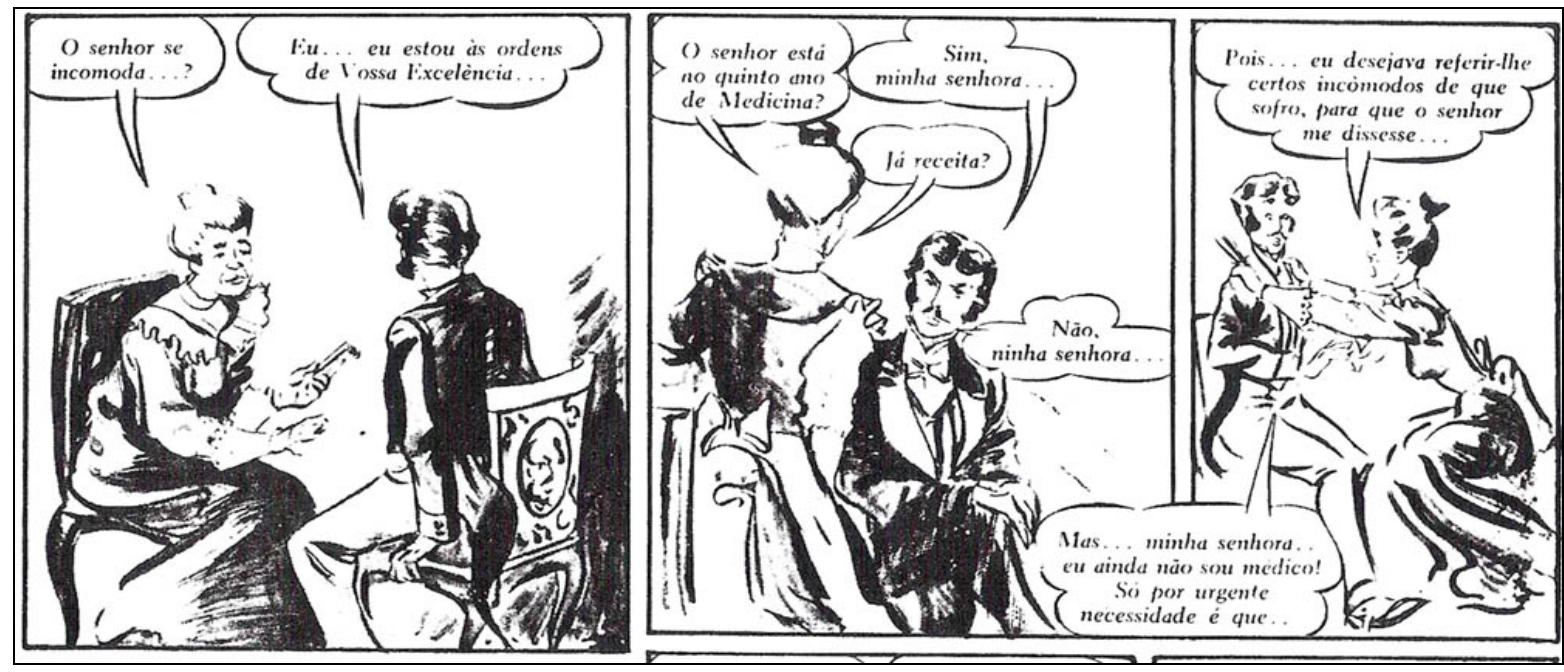

Fig. 25 - Quando os diálogos predominam, o balão é o elemento preponderante (para encaixar todas as falas da cena, é usado o recurso de vazar o balão para o quadro anterior, evitando assim, cobrir as figuras).

Ao observarmos a quadrinização de A Moreninha feita por Gutemberg, percebemos

que há de fato uma preocupação em se preservar a obra-base, numa tentativa de, como afirmado anteriormente, revelar como os quadrinhos podem ser veículos facilitadores para a leitura dos “clássicos”, servindo como meio para despertar a leitura dos mesmos. 
Contudo, mesmo fazendo uso de recursos estruturais das HQs (balões, vinhetas, etc.), tal forma de adaptação parece não dar conta da construção de uma narrativa fluente de quadrinhos. Vale ressaltar que, não é a obra de Macedo que está em foco, mas a obra em quadrinhos que para ser completa, precisa assumir totalmente seus signos. Um aspecto que denota a não completude da adaptação em quadrinho é justamente a pouca integração entre as linguagens verbal e não-verbal, que ressoam uma a outra de forma redundante, dando assim, pouco espaço para que a ilustração acrescente novos nexos à narrativa.

Nas duas cenas abaixo em que temos, em momentos distintos, um duelo de palavras entre as personagens, as ilustrações servem para mostrar e reforçar os fatos narrados nos balões e legendas: o dedo apontado por. Clementina e o beijo que a Moreninha manda para sua rival (Fig.26). Poderíamos pensar o contrário: a linguagem verbal atuando de forma referencial-ilustrativa em relação à linguagem não-verbal, mas devido à preponderância do texto em toda a obra, a forma privilegiada em que a linguagem verbal é mostrada, bem como a simplificação dos traços dos desenhos, muitas vezes quase um borrão, além de sua pouca atuação na construção narrativa - acrescentando poucos elementos para ajudar a contar a estória - percebemos que é de fato a linguagem não-verbal que atua de forma auxiliar/ilustrativa em relação à linguagem verbal. 

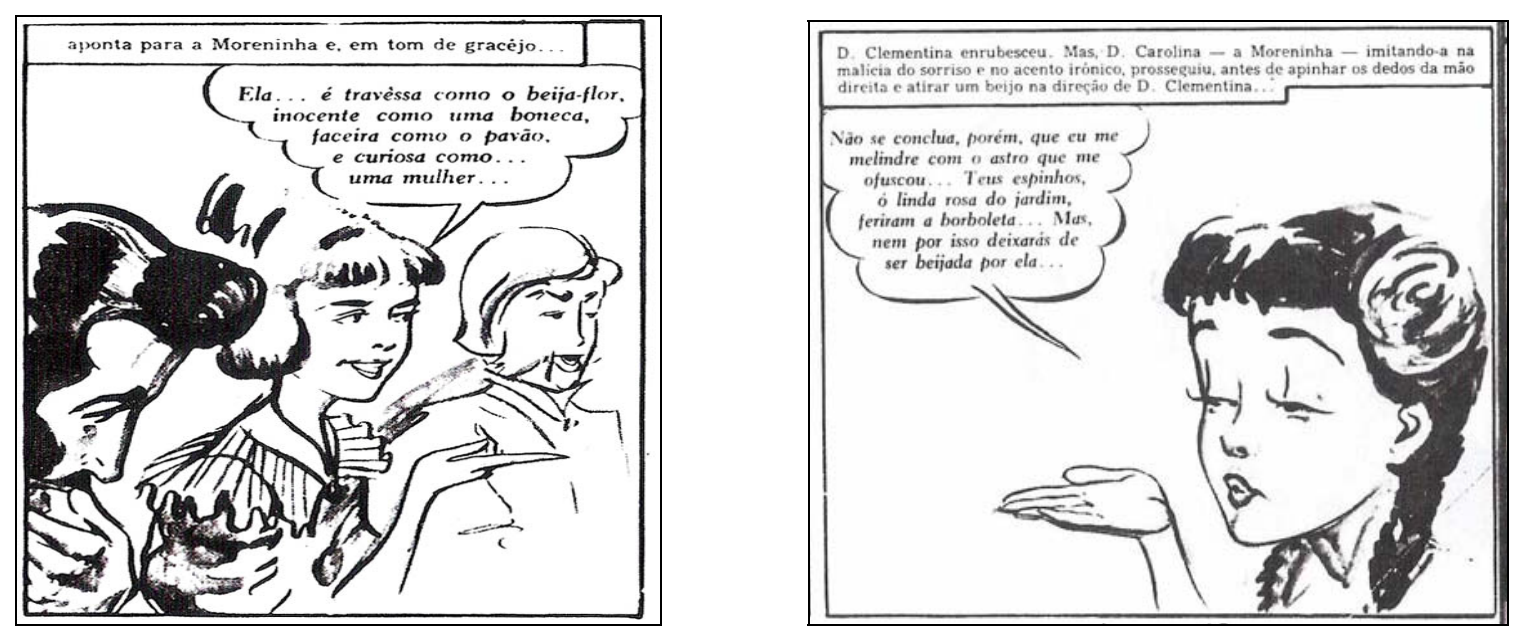

Fig. 26 - Apesar da redundância entre as linguagens, a montagem revela a escolha do momento a ser destacado no trecho, pela ilustração (dentre as várias informações fornecidas pela linguagem verbal): na primeira cena, o gesto de D. Clementina e na segunda, o beijo da Moreninha.

Nesse ponto, vale destacar alguns elementos que integram o "fazer" dos quadrinhos e que são explorados na obra para garantir mais fluência à narrativa, acrescentando à HQ, por meio de sua estética própria, recursos compositivos que não fazem parte da obra literária. Um deles diz respeito aos planos de focalização. As figuras e cenários, apesar de geralmente serem apresentados em ângulo normal, como um olhar de frente, na horizontal, com as personagens quase sempre num plano médio, até a cintura, ou de corpo inteiro, como a visão de um observador onisciente, também são desenhadas, em determinados momentos, com alguns enfoques diferenciados, permitindo maior agilidade na narração. É o que ocorre na figura abaixo, em que temos a panorâmica de um determinado cenário. (Fig. 27). Na obra literária, nos é dada a informação de que as moças conversam em determinado recinto, mas o local não é descrito da maneira como vemos no quadrinho: numa tomada aérea, que se distancia como no movimento de uma câmera (travelling). 


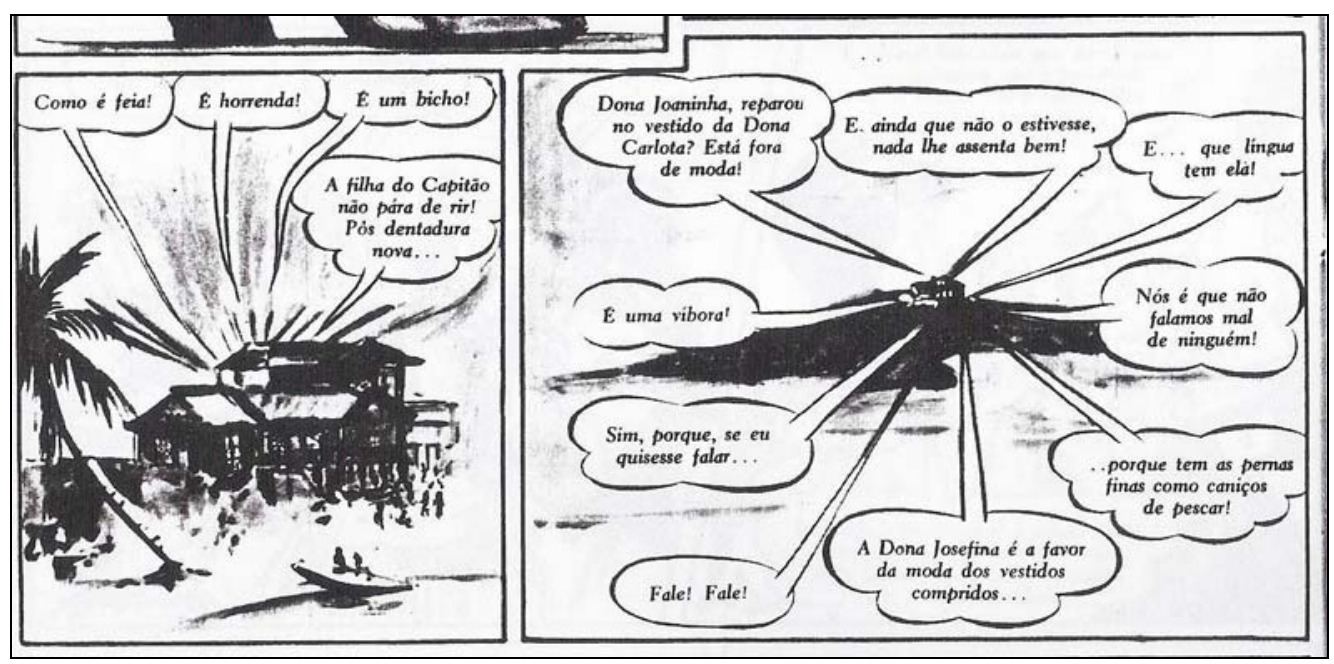

Fig. 27 - Na ilustração, podemos ver a figura de uma casa em panorâmica, numa visão de cima para baixo. Lá é o lugar onde se encontram as moças conversando. $\mathrm{O}$ uso dos balões se revela essencial para a estrutura narrativa, pois permite a realização do diálogo sem que precisemos das personagens em cena (voz off).

Outro recurso que contribui para a composição narrativa na adaptação de $A$ Moreninha, e que também é amplamente utilizado nos quadrinhos para revelar o tempo da narração, são as formas de contorno das vinhetas. Quando Augusto conta em flashback seu primeiro encontro com Carolina, os quadros surgem com uma moldura ondulada, no momento em que revela de forma humorística suas peripécias amorosas, também ocorridas no passado, os fatos vêm apresentados numa espécie de quadro-balão com contorno enegrecido, e ao revelar os fatos do presente, surge o quadro contornado por uma linha reta (Fig.28a, b, c). 


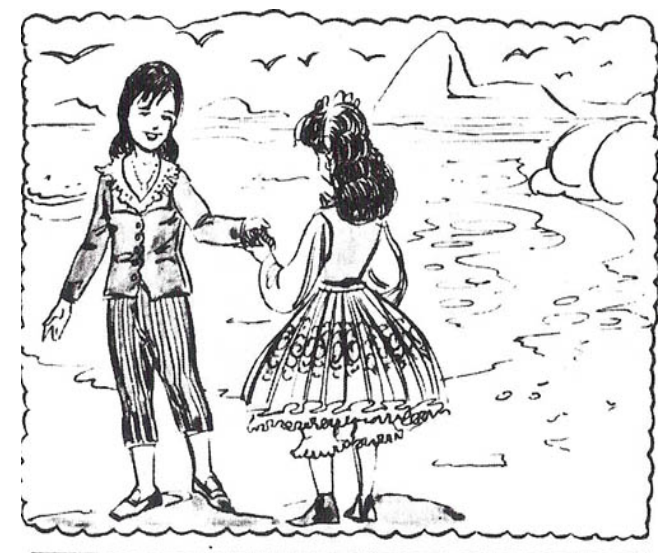

a)

"Ao ouvir aquela voz harmoniosa e vibrante, eu não quis saber de fluxos e refluxos das ondas: corri para elas com entusiasmo, e, radiante de fe. licidade, voltei, um pouco molhado, sim, mas trazendo a concha desejada..."

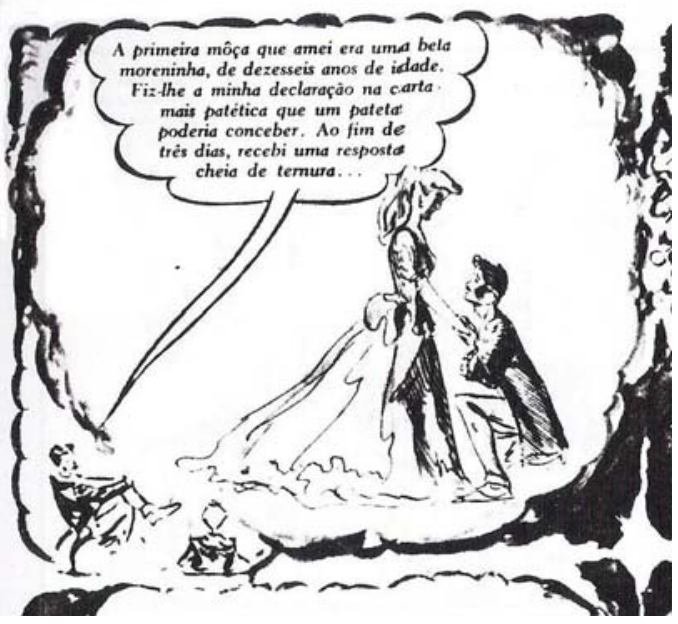

b)

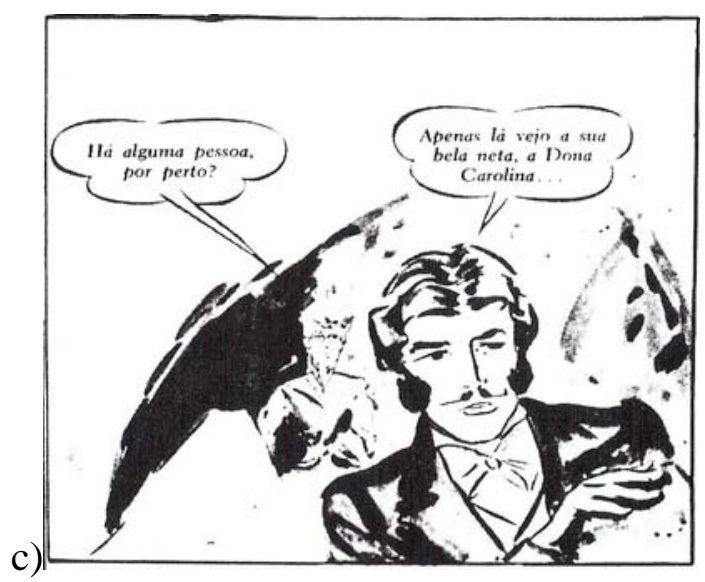

Fig. 28 - A forma de apresentação da fala da personagem que narra os fatos também ajuda a situar o tempo da narração: no primeiro quadro, numa legenda (como em uma voz over), no segundo, pelo uso do quadro-balão com a presença da personagem narradora (Augusto), no tempo presente, também em cena, juntamente com seu duplo, retratado no passado, e no terceiro, veiculada pelo uso dos balões de fala.

Em determinado momento quando D. Ana conta a Augusto a lenda da "História das lágrimas de amor”, os quadros praticamente perdem seu contorno e as figuras surgem quase que apagadas, em linhas tracejadas. Novamente é a linguagem verbal que esclarece e torna compreensível o trecho narrado (Fig. 29). 


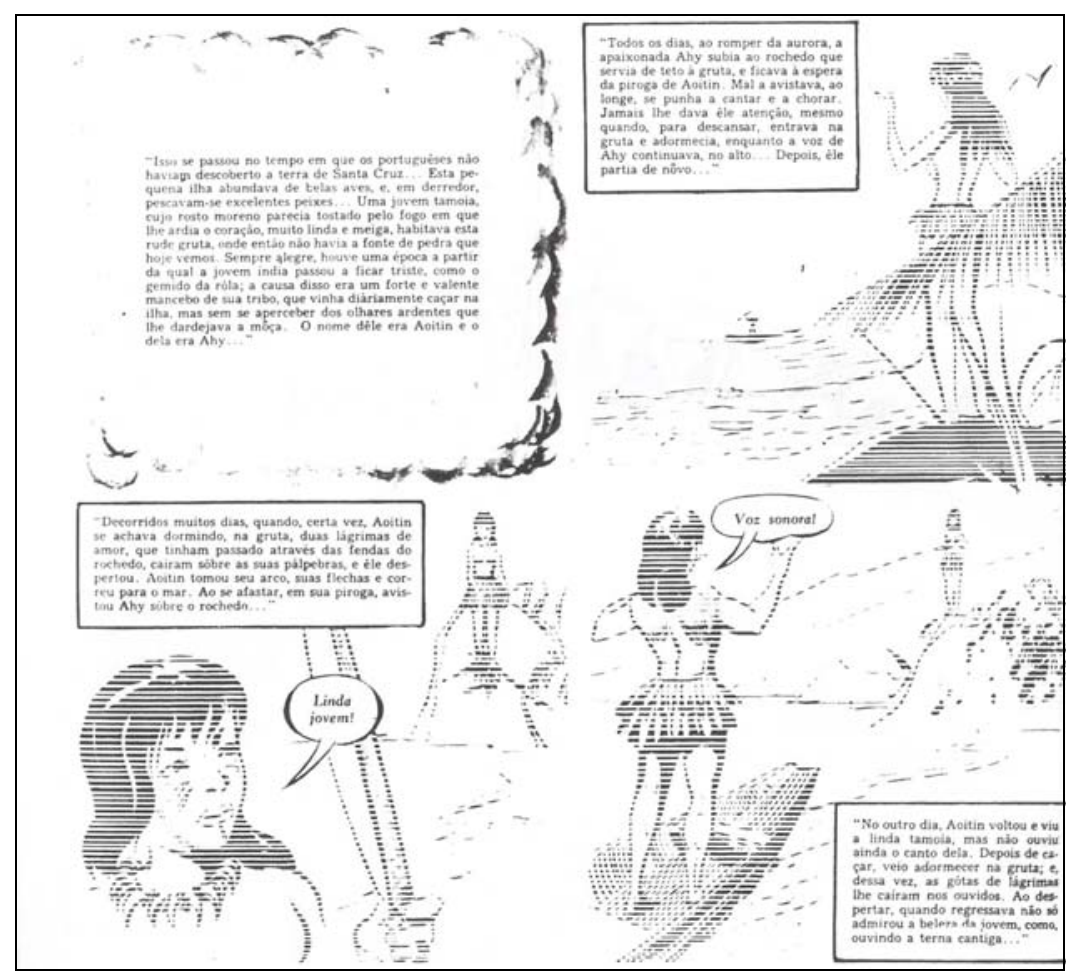

Fig. 29 - As ilustrações tracejadas ajudam a caracterizar outro tempo narrativo (o tempo mítico, da estória narrada por D. Ana), diferenciando dos já utilizados anteriormente.

O uso de recursos próprios das HQs também auxilia na construção narrativa em outros momentos, como quando se faz referência a uma música. Na ilustração, nos deparamos com a figura de Augusto (quem conta o episódio) juntamente com alguns versos acompanhados de desenhos de notas musicais, recurso que facilita o reconhecimento do leitor de que se trata de uma música cantada (Fig. 30). Nesse ponto, vale destacar um outro exemplo de notação musical nas HQs, que mostra como os recursos e linguagens podem se alterar de acordo com a época e/ou contexto. Na obra de Junko Mizuno, diferente do que ocorre na quadrinização de A Moreninha, a música é apresentada de maneira mais visual. 


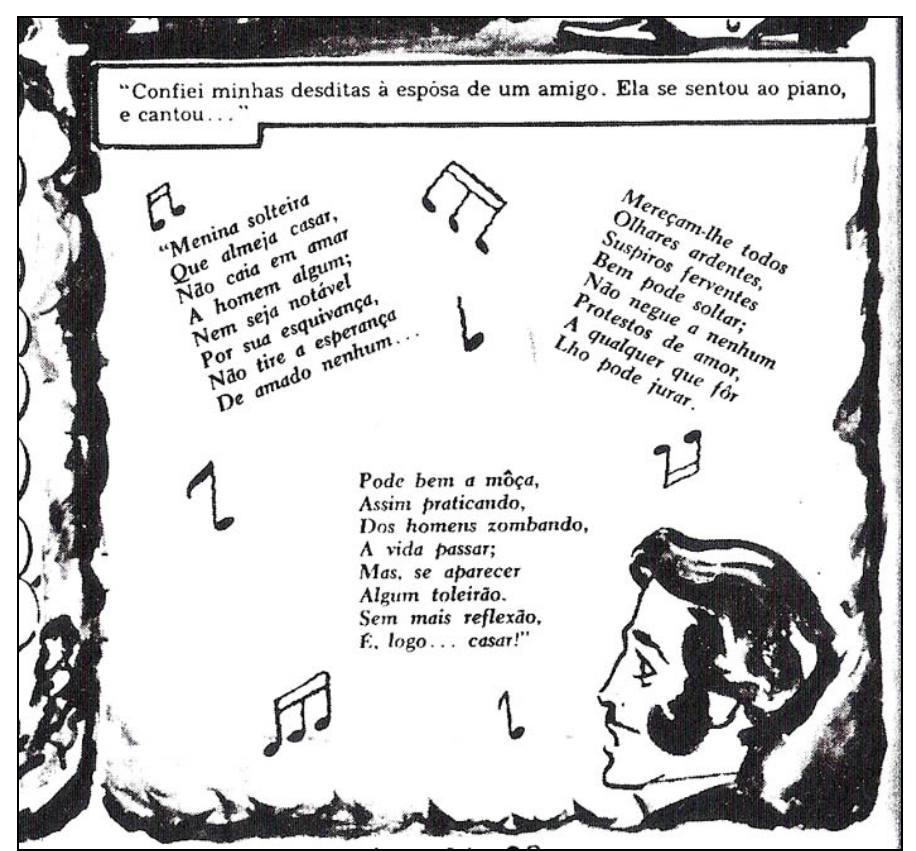

Fig. 30 - A legenda que acompanha o quadro nos dá a informação de que a música foi cantada e o desenho das notas musicais reforçam tal informação.

Junko, em Cinderalla, um mangá japonês publicado em 2000 que adapta de forma nada convencional a estória de Cinderela, traz uma representação musical através do uso de um recurso extremamente atual: o videoclipe, no qual uma das personagens "canta” enquanto imagens rápidas surgem acompanhando os versos. Na obra de Junko, a personagem célebre dos contos de fada é agora um zumbi, bem como o seu príncipe encantado que, além disso, é um cantor famoso. Ao final da estória, ele apresenta seu hit de sucesso: "Eu sei muito bem”. A leitura, seguindo a estruturação dos mangás, ou seja, da direita para à esquerda, é auxiliada pela numeração dos quadros do videoclipe. O tema é a própria morte do príncipe, agora um zumbi, fato ocorrido devido a uma doença incurável, e aos versos tragicômicos são intercalados momentos instrumentais, identificados pela linguagem verbal. A relação entre as linguagens se dá, em grande parte, de forma complementar, já que cada uma contribui para construir a narrativa musical (fig. 31). 


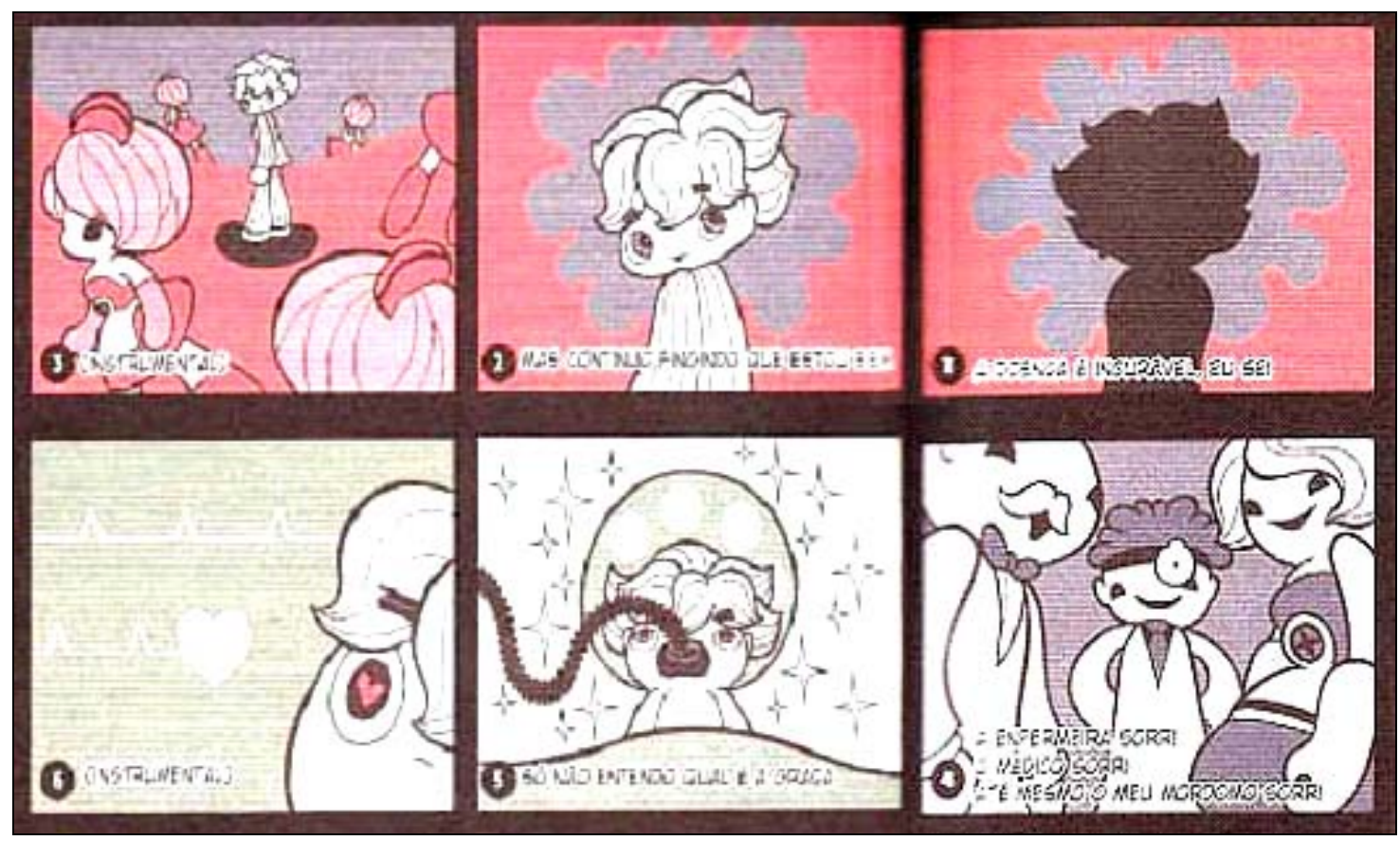

Fig. 31 - Os desenhos corridos ajudam na significação do enredo musical, cujo tema é a doença do príncipe (que o leva à morte) e o comportamento das pessoas diante de tal fato (elas riem, apesar do drama vivido por ele).

Mesmo neste formato, adaptação pastiche, em que se procura reproduzir de maneira fiel o enredo e a maneira de se contar a estória, na obra em quadrinhos o texto-base sofre determinada interferência. Um exemplo é a materialização das personagens e cenários que apesar de descritos abundantemente no texto de Macedo, são apresentados a partir do ponto de vista de um determinado “olhar”. Também há a inserção da presença da "câmera” trazendo uma perspectiva de visão, em determinados momentos, não elencados no romance de Macedo. Tais elementos apontam para o fato de que não há transposição sem interferência, mesmo que mínima, uma vez que cada meio traz em si recursos estéticos próprios, oferecendo novas formas de construir a narrativa. 
De uma maneira geral, o que se depreende da quadrinização de A Moreninha é que temos uma adaptação em HQ tão “clássica” quanto a obra original. Há pouca inserção do aspecto lúdico e ao mesmo tempo de elementos que possibilitem o uso amplo da imaginação. O seu caráter pedagógico é representado por meio do didatismo da configuração narrativa e corresponde a uma determinada forma de compreender a maneira como o didático deve ser estruturado. Estamos diante de uma obra realizada em 1953, época em que a ideologia em torno da educação favorecia tal forma de pensamento. Mas será que hoje, a maneira de se encarar os recursos pedagógicos se alteraram? Vejamos como outra adaptação, realizada em 2006 trabalha com o aspecto didatizante do diálogo entre obras, com os elementos oriundos da tradição e com os recursos estéticos dos quadrinhos.

\section{b) Gaetaninho - crônica em quadrinhos}

A escolha do conto Gaetaninho, de Antonio de Alcântara Machado, adaptado por Jo Fevereiro em 2006 para a coleção Literatura Brasileira em Quadrinhos das edições Escala Educacional, faz parte da renovada e atual tendência para a redescoberta dos autores do passado. Nessa quadrinização, podemos verificar algumas características elencadas anteriormente e que aproximam a composição em quadrinhos da obra original literária. Aqui também está evidente o caráter pedagógico da adaptação, aliás, os próprios editores advertem para o fato de que "essa linguagem não substitui a forma original da obra, cuja leitura permanece essencial à boa formação do leitor” (MACHADO, 2006, p.2). 
Sobre os contos modernistas de Alcântara Machado, que figuram no livro Brás, Bexiga e Barra Funda (1927), do qual o conto Gaetaninho faz parte, é importante destacar seu alto teor jornalístico e intenção crítica, aspectos reforçados pelo próprio autor que inicia o livro com a seguinte advertência: “Este livro não nasceu livro: nasceu jornal. Estes contos não nasceram contos: nasceram notícias. E este prefácio, portanto também não nasceu prefácio: nasceu artigo de fundo” (MACHADO, 1927, p.15). Dentre as principais características dos contos da coletânea, segundo Ataíde (1972), podemos destacar: leveza narrativa, humor, preocupação mais sócio-humana do que psicológica, estórias singelas e humanas, lirismo, presença de personagens sofridas e que fazem parte do cotidiano, uso de frases curtas, palavra veloz, certa oralidade narrativa.

A problemática central dos contos é a presença do emigrante italiano, na vida urbana paulista dos anos 1920. A narração se dá por meio da observação de um narrador onisciente e a forma de tratamento da matéria literária é a de um documentário: “[...] documentário urbano social, com preocupações realistas de reprodução fidedigna, ou pelo menos verossímil da realidade, de maneira a emprestar às narrativas indiscutível caráter de autenticidade” (MACHADO, 1970, p.63).

No conto Gaetaninho, a trama se desenvolve em torno de um garoto italiano e pobre, com seu grande desejo de andar de carro, numa São Paulo do início do século XX, quando a presença de um automóvel em meio aos bondes e carroças era um acontecimento notável. O desejo da personagem título de andar de carro serve de mote para o autor traçar 
um painel da vida urbana em São Paulo nos anos 20. O sonho de Gaetaninho é ingênuo, mas, mais do que o ato em si, representa o espírito empreendedor do imigrante italiano e seus sonhos de sucesso social, de status. Gaetaninho só consegue realizar sua vontade quando morre e, enfim, é carregado num carro durante o enterro.

A partir do texto de Machado, os elementos utilizados no quadrinho para corporificar a narrativa procuram acentuar a característica visual e ágil do conto, com recortes e sobreposições de quadros e figuras. Aqui também estamos diante de uma adaptação pastiche, na medida em que além de haver uma tentativa por manter a obra com poucas interferências também se busca transportar para os quadrinhos o estilo narrativo com caráter jornalístico-documental do conto de Machado.

Já na primeira página podemos ver a busca por uma montagem visual mais ágil, quando as vinhetas quadriculam a figura, separando-a em partes apesar de se tratar de um único cenário em um mesmo momento (Fig. 32). A divisão, ao invés de dividir as imagens numa seqüência de tempo, serve para separar as informações fornecidas pela linguagem verbal que vem nas legendas e nos balões, acentuando a impressão de simultaneidade, vários episódios/falas acontecendo ao mesmo tempo: enquanto o carro passa, Gaetaninho caminha pelo meio da rua, as pessoas o observam da calçada e o carroceiro anda ao seu lado.

Apesar do elaborado recurso visual, a relação entre as linguagens verbal e nãoverbal é de redundância, na medida em que o texto apresentado nas legendas é reproduzido 
pelas ilustrações que o acompanham. Na quadrinização de Gaetaninho, aliás, a redundância entre as linguagens é mais preponderante do que no quadrinho de A Moreninha, principalmente pelo fato de haver poucos diálogos, daí o escasso uso dos balões, predominando assim as legendas com a voz do narrador onisciente, da mesma forma que no conto de Machado, contando os episódios que envolvem Gaetaninho (episódios que são ratificados pela linguagem não-verbal, em consonância com o texto verbal). A dinamicidade da obra é representada não por meio dos balões, elemento que costuma desempenhar esse papel, mas sim pela exploração das vinhetas, talvez numa referência ao caráter documental do conto, já que o documentário traz o "olhar" do outro sobre determinada situação, aspecto que é destacado pela forma como a obra é conduzida. 


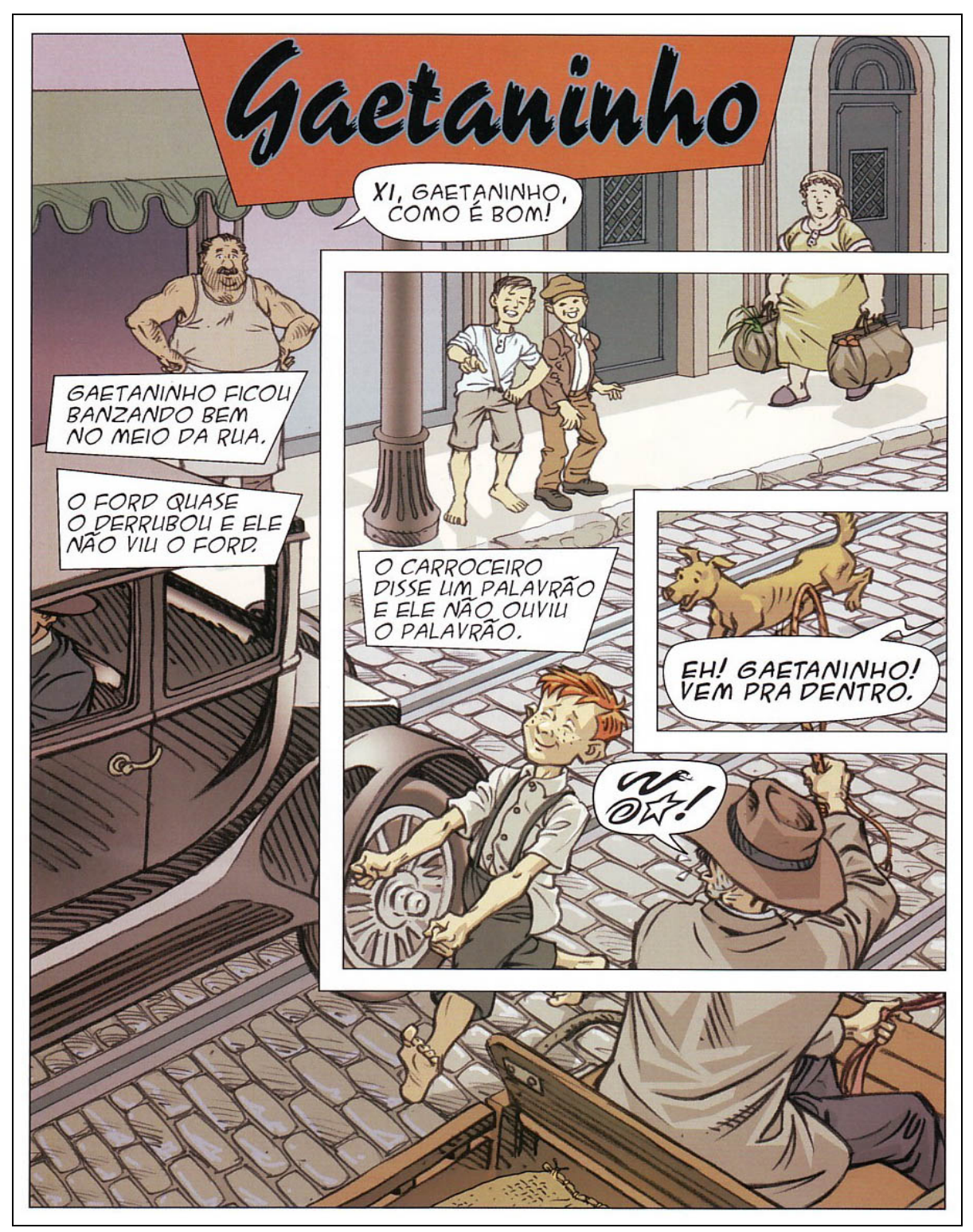

Fig. 32 - A linguagem não-verbal apesar de atuar em grande parte da cena de forma redundante à linguagem verbal, acrescenta elementos não mencionados pelo texto, como a senhora caminhando, o cachorro, etc., mas se tratam, sobretudo, de recursos cênicos, que enriquecem o cenário, acrescentando pouco à narrativa em si. O balão, por sua vez, apesar de só aparecer em três momentos na ilustração, acrescenta mais significação à ilustração e confere um maior dinamismo entre as personagens. 
Um outro exemplo da diagramação quadriculada usada no início da obra também pode ser vista no momento em que Gaetaninho ouve a mãe o chamando (Fig. 33). A vinheta é utilizada de maneira hábil, fracionando o desenho numa focalização em pedaços da cena.
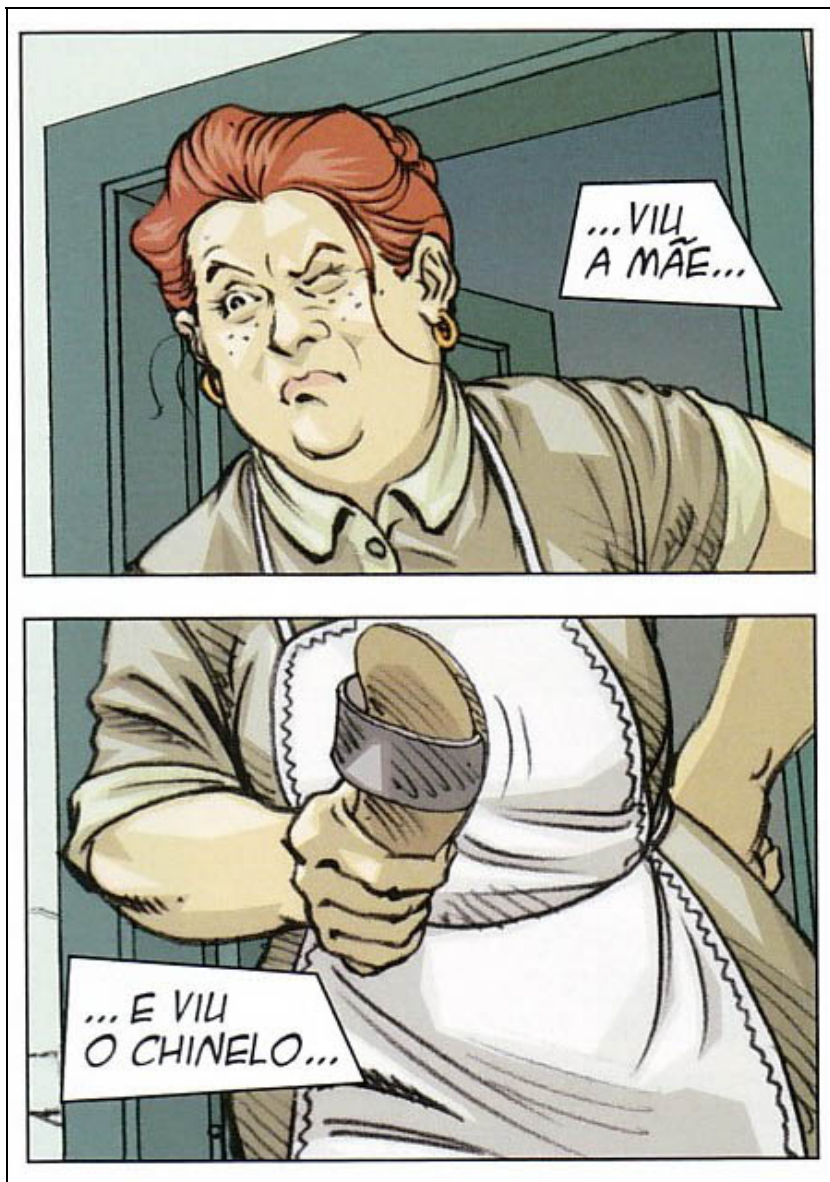

Fig. 33 - As ilustrações revelam os elementos na ordem em que são vistos pelo menino: primeiro a mãe e depois o chinelo. Em cada quadro, as linguagens ressoam uma a outra (o que é visto pela ilustração também é descrito na legenda).

Tais elementos, além da forma de representação visual das cenas, conferem maior leveza e certo caráter lúdico à obra. Apesar de a adaptação apresentar uma construção narrativa que acaba por enquadrar e direcionar a interpretação final, os traços, que pendem para o caricatural ajudam a acrescentar certo humor nas seqüências, humor irônico que, 
aliás, está presente no texto de Machado. As cores em tom pastel e a configuração do cenário, ricamente detalhado, remetem para uma época antiga, talvez a São Paulo dos anos 20. Essa forma de apresentar a ilustração na obra revela uma maior exploração de aspectos plásticos da linguagem não-verbal presente nos quadrinhos, ampliando o caráter imagético da mesma e tornando sua "leitura visual” mais acessível.

A apresentação de diferentes planos e pontos de vista dão maior força expressiva as seqüências. Temos a visão do alto, como se estivéssemos de cima observando os fatos, o close up, mostrando detalhes da cena, e outros. É o que ocorre quando Gaetaninho se imagina na boléia de um carro acompanhando um enterro (Fig. 34). A visão de baixo para cima o engrandece, reforçando a sensação que ele tem ao se imaginar daquela forma. Em outra cena, quando os meninos jogam bola, vemos a imagem de cima para baixo (Fig. 35), dando a sensação de que a "câmera” que os focaliza se encontra no alto, até a presença de um pássaro na beirada do telhado reforça tal sensação. 


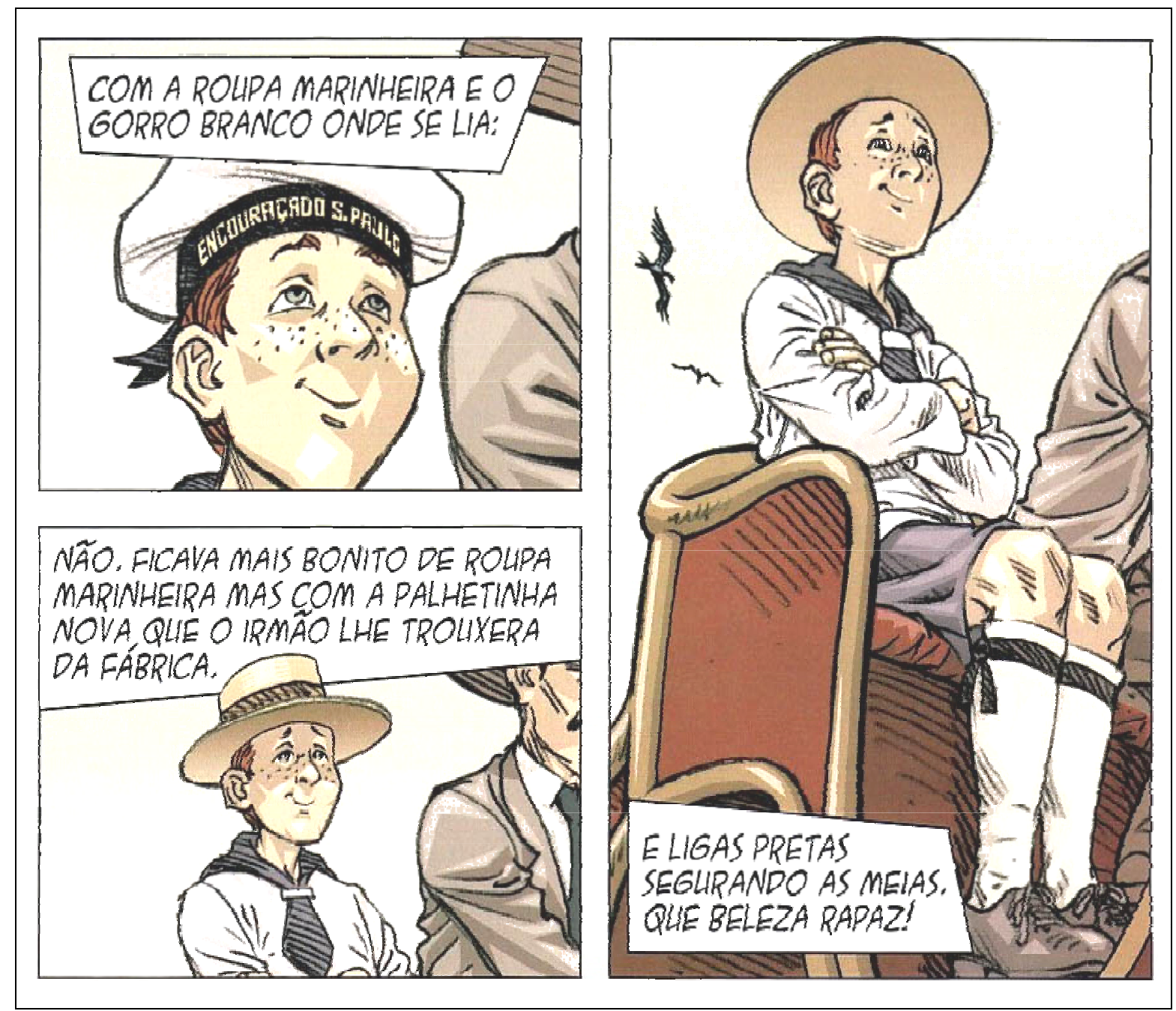

Fig. 34 - Gaetaninho sonha com uma viagem de carro, imaginando detalhes da roupa e dos acessórios que usa naquele momento. Sua figura imponente (reforçado pelo ângulo de visão da "câmera”) e o olhar sonhador refletem como ele se sente: importante. 


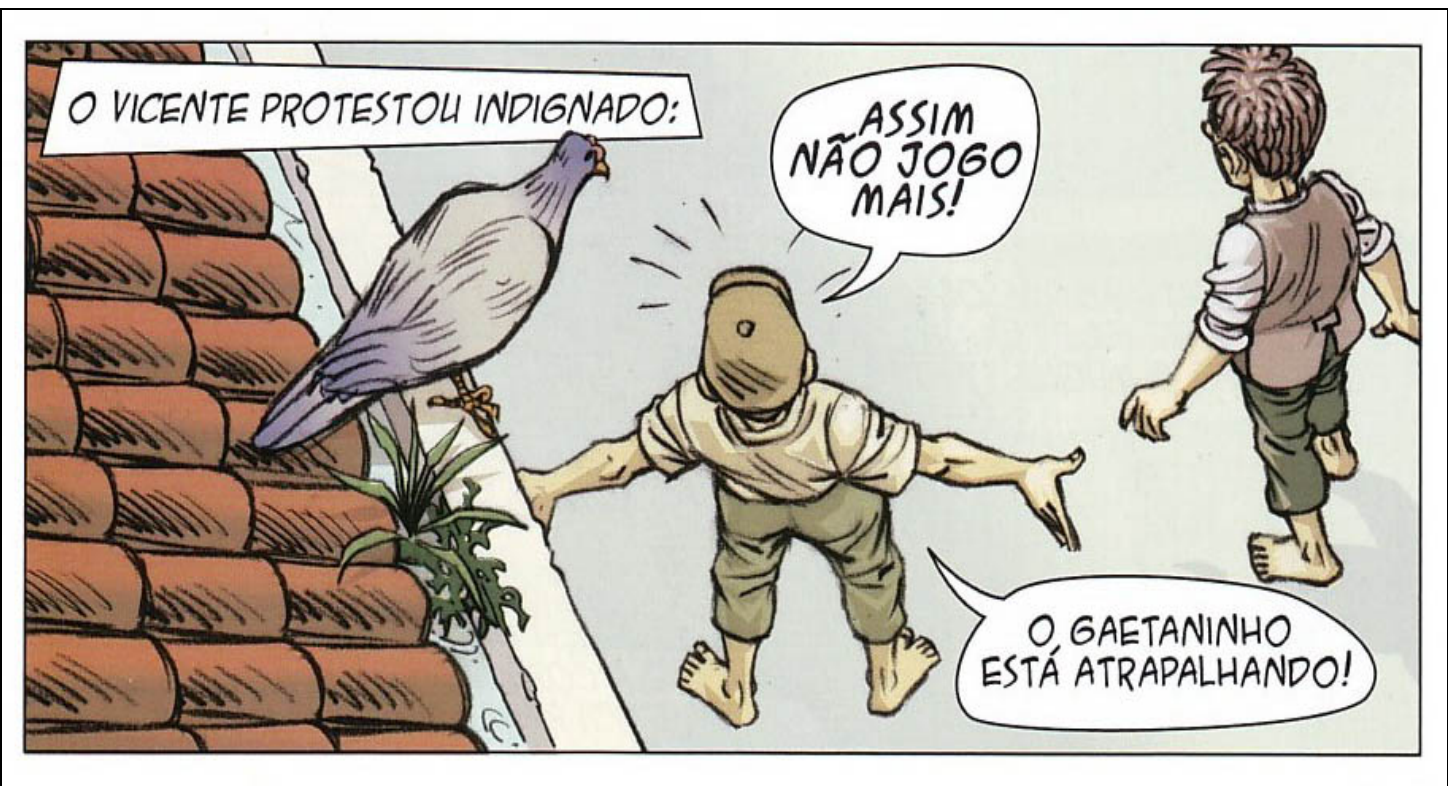

Fig. 35- A forma como as figuras dos meninos são desenhadas (esmagadas contra o chão), ampliam a sensação de altura.

A seqüencialidade das ilustrações, bem como a escolha dos momentos a serem quadrinizados ajudam a relatar episódios importantes da narrativa, dando-lhes mais dramaticidade, como quando Gaetaninho morre (Fig. 36). O uso da linha branca em volta dos pés de Gaetaninho bem como o quadro com fundo preto (remetendo ao luto) são recursos que ampliam o aspecto trágico do momento. Esse é outro exemplo da exploração eficiente dos recursos dos quadrinhos para compor a obra.

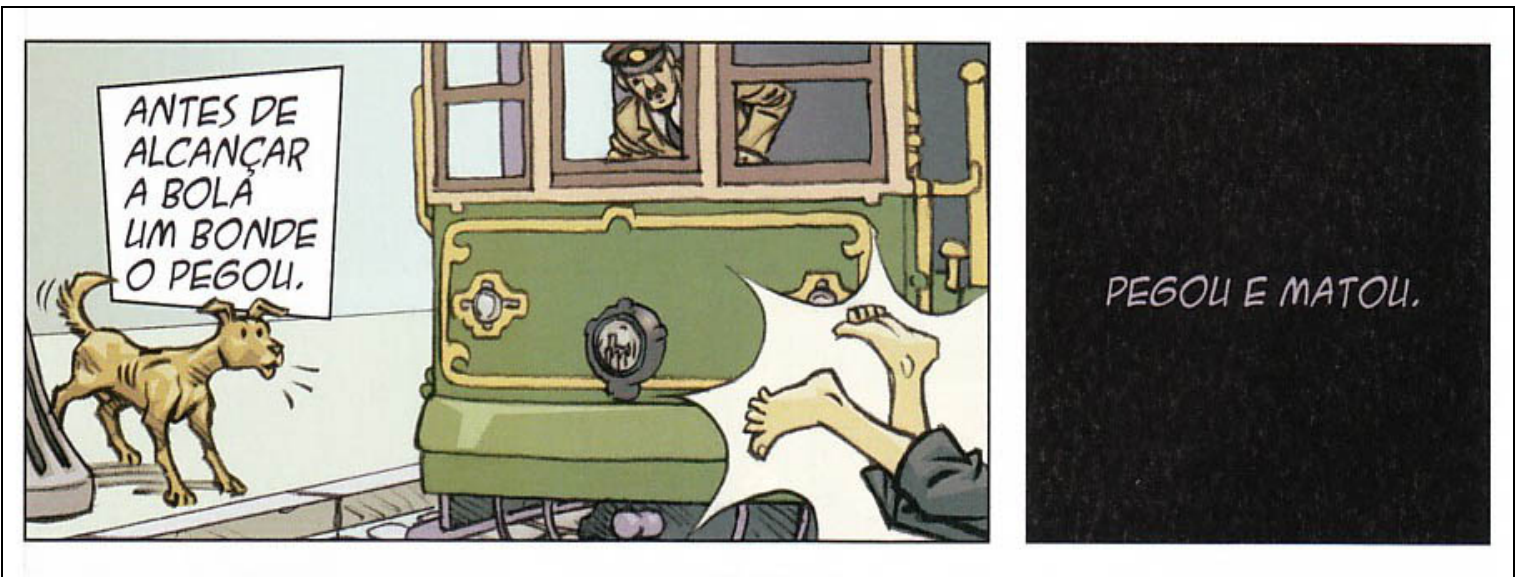

Fig. 36 - A linguagem verbal assume a função explicativa no contexto. 
A quadrinização de Gaetaninho traz em si elementos que remetem a forma didatizante encontrada em A Moreninha, em que o quadrinho é apresentado como uma obra auxiliar à original, facilitando sua leitura. Porém a forma de realização desse intento difere um pouco da vista anteriormente. Aqui também temos uma tentativa de reprodução "fiel” do texto-base e de alguns de seus recursos estilísticos: o caráter documental, a agilidade jornalística, etc., com uma adaptação que acaba por direcionar a interpretação final.

Contudo há uma diferenciação inserida pela construção da identidade visual da obra. É por esta via que o humor se insere, bem como o lúdico e a leveza narrativa. De certo que tais aspectos também estão presentes no texto de Machado, só que representados pela linguagem verbal. Na HQ, apesar do uso constante de legendas e da relação redundante entre as linguagens, é pelo visual que tais elementos se materializam.

\subsubsection{Inserção de novas dimensões narrativas}

Como já destacado ao longo desse trabalho, as formas de adaptação/diálogo entre obras e suportes são variadas. Tudo depende do objetivo e da maneira como os recursos estéticos são utilizados. Além do pastiche, visto no item anterior, outras formas de adaptação podem ser realizadas, como no caso de obras que procuram inserir outras dimensões narrativas, seja pela contribuição da linguagem não-verbal, contando a estória de diferentes maneiras, não mencionadas pela linguagem verbal, seja pela utilização de novos argumentos acrescentados por essa, que ampliam e/ou modificam o texto-base, sem que, contudo, percamos a intriga do enredo original. Não se trata de um distanciamento total da 
obra-base, criando a partir dela diferentes obras, mas a introdução de elementos que permitam novas construções narrativas dentro do enredo original, para modificar determinados aspectos do texto original ou para ajudar a contar de outra maneira a mesma obra. Estaríamos, portanto, diante de uma adaptação criativa, em que há a integração de novos recursos para acrescentar outras possibilidades narrativas à obra-base. A obra original produzida na literatura ainda é o principal recurso da narração, mas outros elementos começam a interferir, a “contaminar” o texto-base.

Assim como ocorre em diferentes formas de interação entre obras, aqui também teremos uma gradação, em que algumas obras se colocam mais próximas do texto-fonte enquanto outras procuram se distanciar mais. A seguir, temos dois exemplos diferentes que trazem possibilidades variadas de interferência na obra-base: no primeiro, há a inserção, principalmente por meio da linguagem não-verbal, de uma nova dimensão narrativa; já no segundo caso, a linguagem não-verbal assume a narração dos fatos.

\section{a) Os Lusíadas: uma aventura intergaláctica}

Na releitura que Lailson de Carvalho faz da obra Os Lusíadas de Luís Vaz de Camões, realizada em 2006 para a Companhia Editora temos outra dimensão visual unida ao poema do célebre poeta. Em Lusíadas 2500, os versos da obra original, mantidos sem alteração, e sem redução/edição, daí a obra ser publicada em três volumes, são acompanhados por uma nova dimensão narrativa inserida pela linguagem não-verbal, que 
situa as aventuras narradas no poema numa época futurista, o ano 2500 do título, revelando um salto temporal e espacial. No novo contexto, as caravelas de Camões não navegam mais em mares bravios, mas no espaço sideral. As ilhas desconhecidas flutuam no universo, junto a planetas e asteróides misteriosos. O autor, apesar de desenhar um novo cenário para os eventos narrados nos Lusíadas, procura ajustá-los aos versos de Camões. Assim, quando se faz uma referência às ilhas desconhecidas no texto, temos em contrapartida o desenho de uma ilha, só que flutuando nos céus.

Na verdade, a adaptação do poema épico de Camões para uma época futurista e intergaláctica, não muda apenas o cenário das ações, altera também o gênero da obra, que, com tal ambientação, se torna uma ficção científica. Outro elemento, além dos cenográficos, que reforça tal mudança é a inserção de diálogos (outra inovação da obra em quadrinhos) entre Vasco da Gama e um robô, o registrador KMOS1572, numa referência ao próprio Camões e à data de criação dos Lusíadas, que traz o DNA do poeta e é o responsável por registrar e contar para o rei os feitos de Vasco e sua tripulação. Nesses momentos temos uma configuração própria de quadrinhos, com balões, vinhetas, etc., ao passo que ao longo da obra, quando temos os versos de Camões, os desenhos acompanham o texto verbal de uma forma ilustrativa. Os trechos de diálogo, que revelam o discurso direto inserido no poema épico português, servem como elemento de ligação entre os episódios narrados em Os Lusíadas, além de ajudar a explicar o que neles vêm narrado e ampliar a nova dimensão narrativa inserida: a futurista. São nesses trechos que vemos o robô interagindo, numa linguagem moderna e espacial, com Vasco e outras personagens. 
A presença dos diálogos juntamente com os versos de Camões aponta para dois aspectos distintos: um em que temos o quadrinho propriamente dito, com os elementos que o identificam como tal, vinhetas, balões, etc., e outro com a obra ilustrada, com legendas trazendo o texto de Camões acompanhado de ilustrações referenciais ao que está sendo dito, sem uma integração entre as linguagens verbal e não-verbal como ocorre nos quadrinhos. Na verdade, tal configuração aponta para a existência de uma obra, a dos quadrinhos, dentro de outra, a narrativa de Camões. É importante destacar que, o pouco uso dos recursos próprios das HQs reforçam a sensação de uma menor interação entre as linguagens verbal e não-verbal no decorrer da obra.

A ambientação futurista e espacial está presente tanto na linguagem não-verbal, pelo desenho de elementos que remetem à ficção científica como barcas flutuando no espaço, planetas, etc., quanto na verbal, no momento em que o diálogo é inserido na narrativa (fig. 37). 


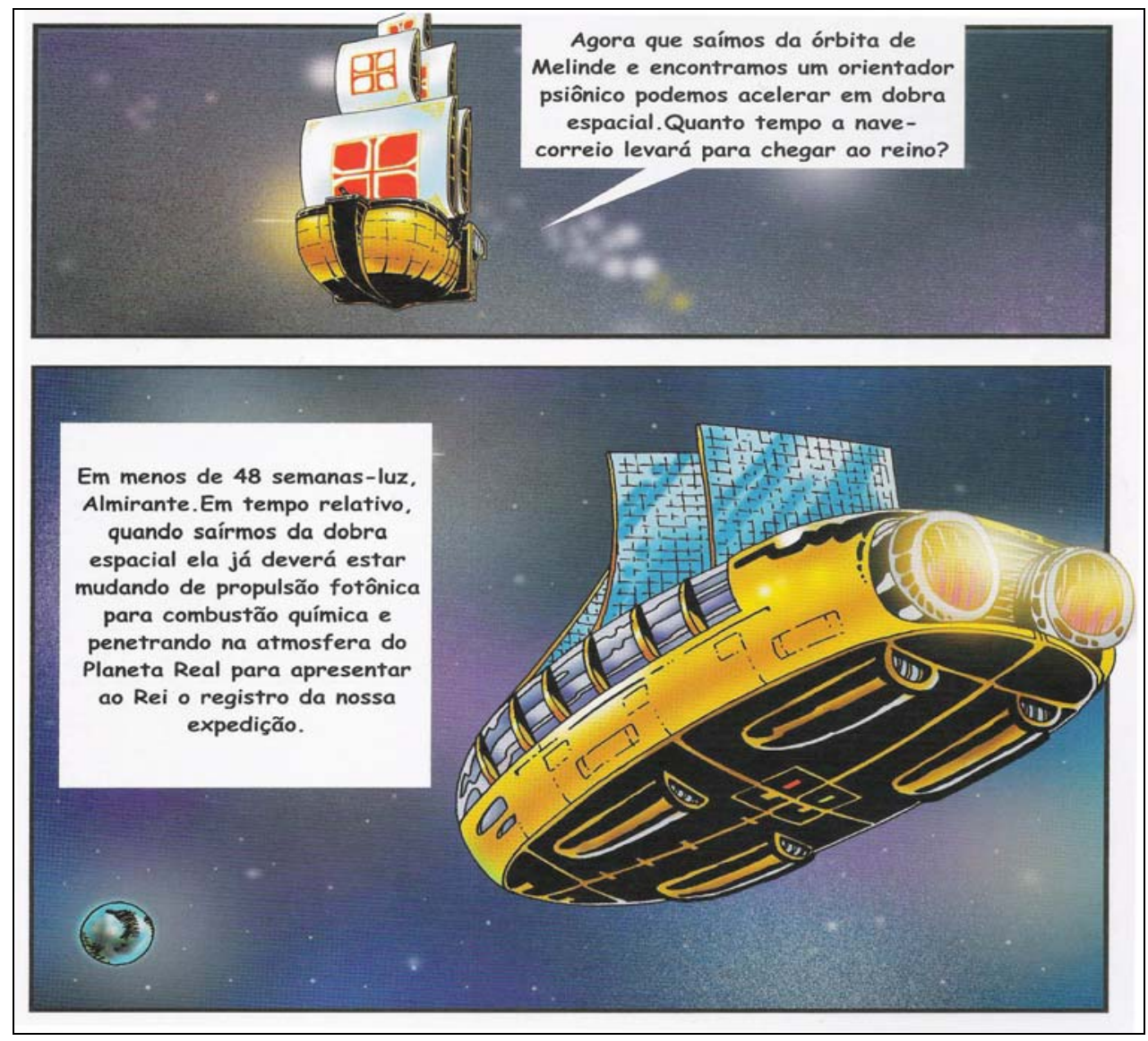

Fig. 37 - As ilustrações fazem uso de ângulos variados (normal, plongeé, etc.) para demonstrar o movimento das naves pelo espaço.

No $1^{\circ}$ volume de Lusíadas 2500, constam os quatro primeiros cantos do poema épico de Camões, narrando desde a proposição, a viagem propriamente dita, o concílio dos deuses para deliberar sobre a sorte dos portugueses, a chegada a Moçambique, o ataque dos mouros e a recepção em Melinde, quando então, Vasco rememora a história de Portugal. Sobre o tema da narrativa de Camões, vale destacar o que diz Luis Piva (1980, p.20):

Em Os Lusíadas, a espinha dorsal em torno da qual gravitam acontecimentos passados, presentes e futuros é a navegação de Vasco da Gama. Na viagem de Gama à Índia se inserem os feitos de reis e príncipes portugueses da Idade Média e várias ações de diferentes varões levadas a efeito através dos tempos. 
Nos quadrinhos também temos a mesma temática de Camões, só que agora unida ao subtexto futurista. Na introdução somos informados de que é o registrador KMOS1572 quem tem a missão de contar a estória que se inicia no ano I da Era das Navegações Galácticas. Segundo ele, o registro das aventuras é feito "Para que o futuro não desconheça o passado e para que os nomes destes heróis fiquem inscritos para sempre nos mais profundos mares e nas mais distantes estrelas, deixei registradas nestas páginas suas histórias, seus combates e suas vitórias” (p.I).

Já nas primeiras páginas da HQ, ficamos sabendo que os tripulantes se encontram numa nave de onde enviam para o rei, com o auxilio do robô registrador, mensagens sobre as suas aventuras pelos mares espaciais. As mensagens são, no caso, os próprios versos de Camões, proferidos pelo robô narrador. A referência a humanóides habitando as ilhas, bem como o desenho de seres interplanetários reforçam o contexto de ficção científica (Fig. 38). 


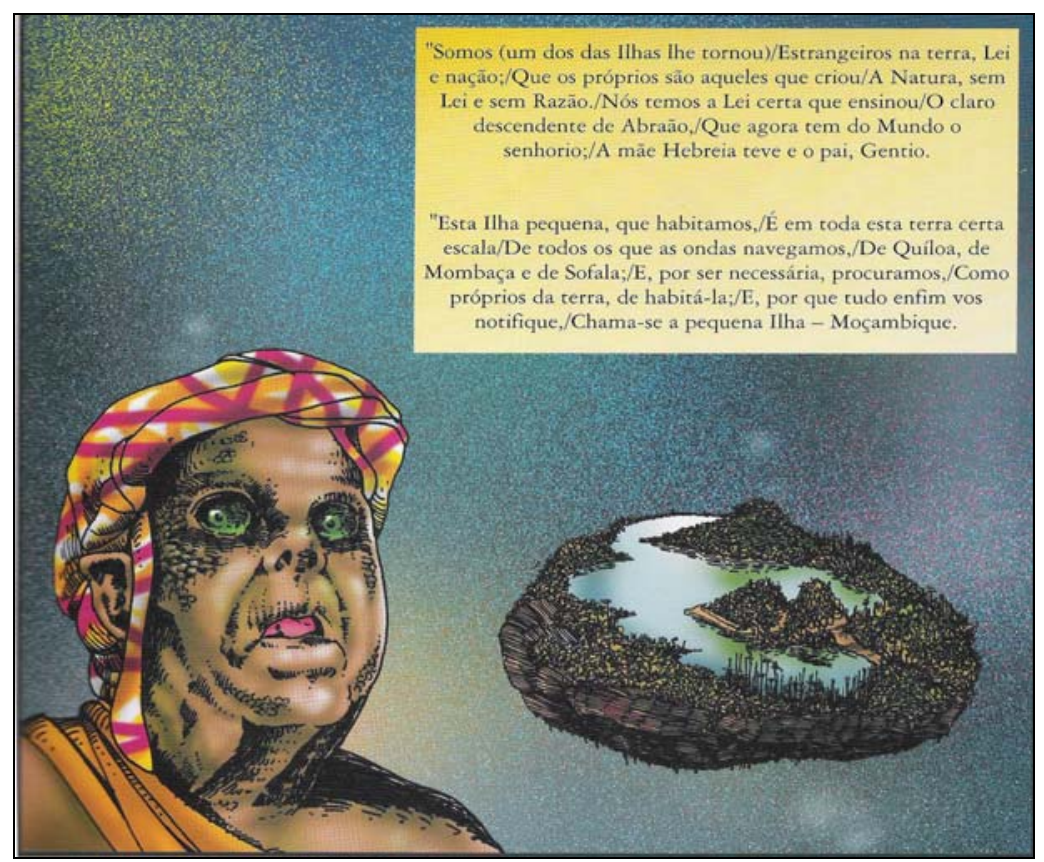

Fig 38 O habitante identifica-se para Vasco da Gama e descreve sua ilha. Na legenda temos os versos de Camões, que dão voz ao estranho ser. Na verdade, o poeta se refere aos habitantes de Moçambique.

Apesar do contexto futurista, vale destacar a co-existência de dois momentos na HQ: o passado e o futuro, numa dupla ambientação que permeará toda a obra, misturando elementos como caravelas, naves, castelos antigos, roupas de época, efeitos de luz e tecnologia, etc. (Fig. 39). Assim, ao mesmo tempo em que temos um cenário espacial, também vemos objetos que fazem parte do antigo, como a caravela, ao invés de um moderno foguete. 


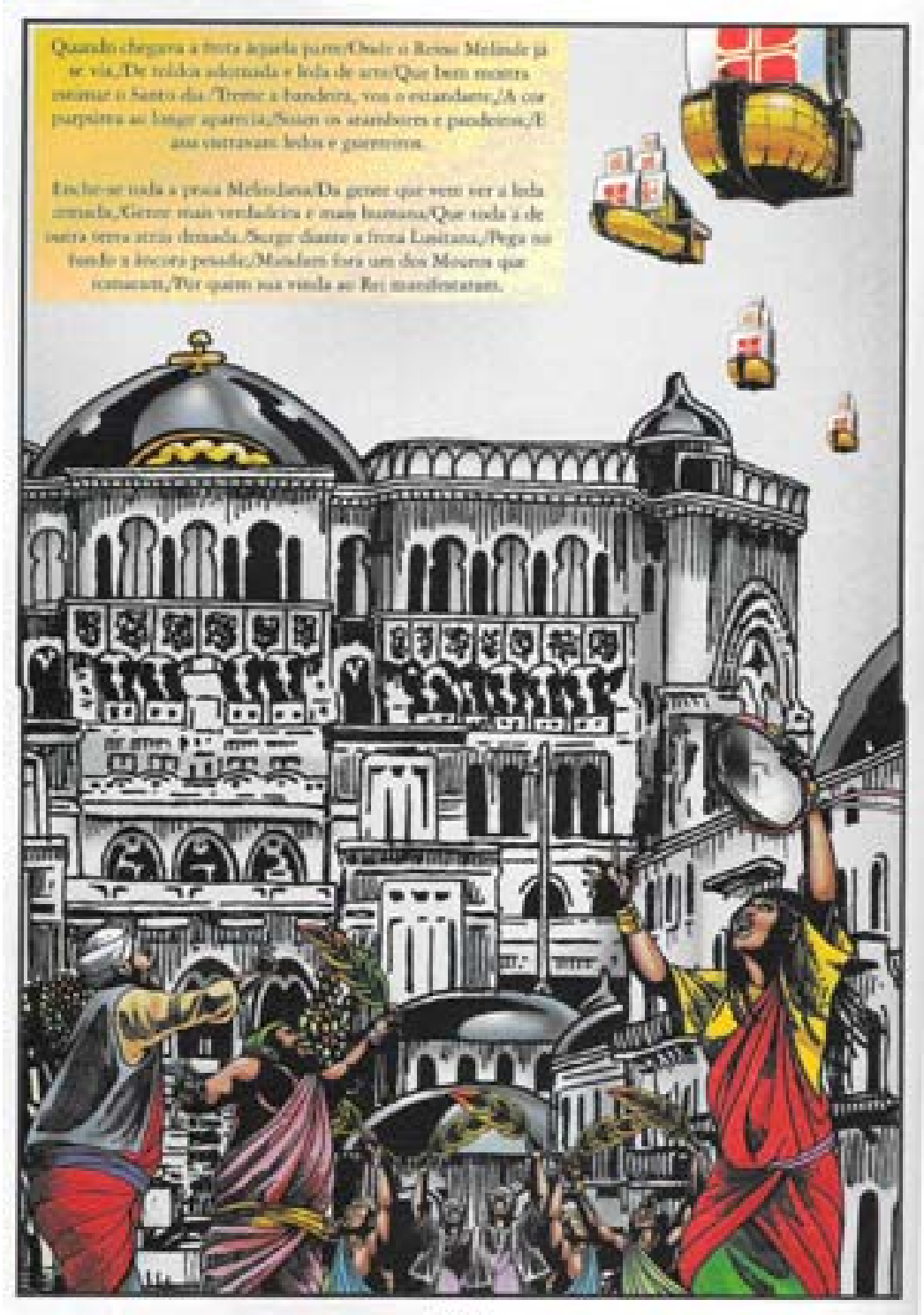

Fig 39 - Enquanto em terra vemos os habitantes de Melinde numa referência à época dos descobrimentos, nos céus, o desenho de caravelas flutuando criam um efeito diferente à narrativa (futurista).

Assim como em A Moreninha, temos o uso de elementos gráficos para dividir o tempo (passado, presente), auxiliando na composição narrativa em determinados trechos, como quando Vasco da Gama conta para o rei de Melinde os fatos passados da história de Portugal. O trecho de diálogo que antecede a narrativa de Vasco da Gama explica como o rei de Melinde poderá ver os acontecimentos históricos narrados em tempo real (fig. 40). 

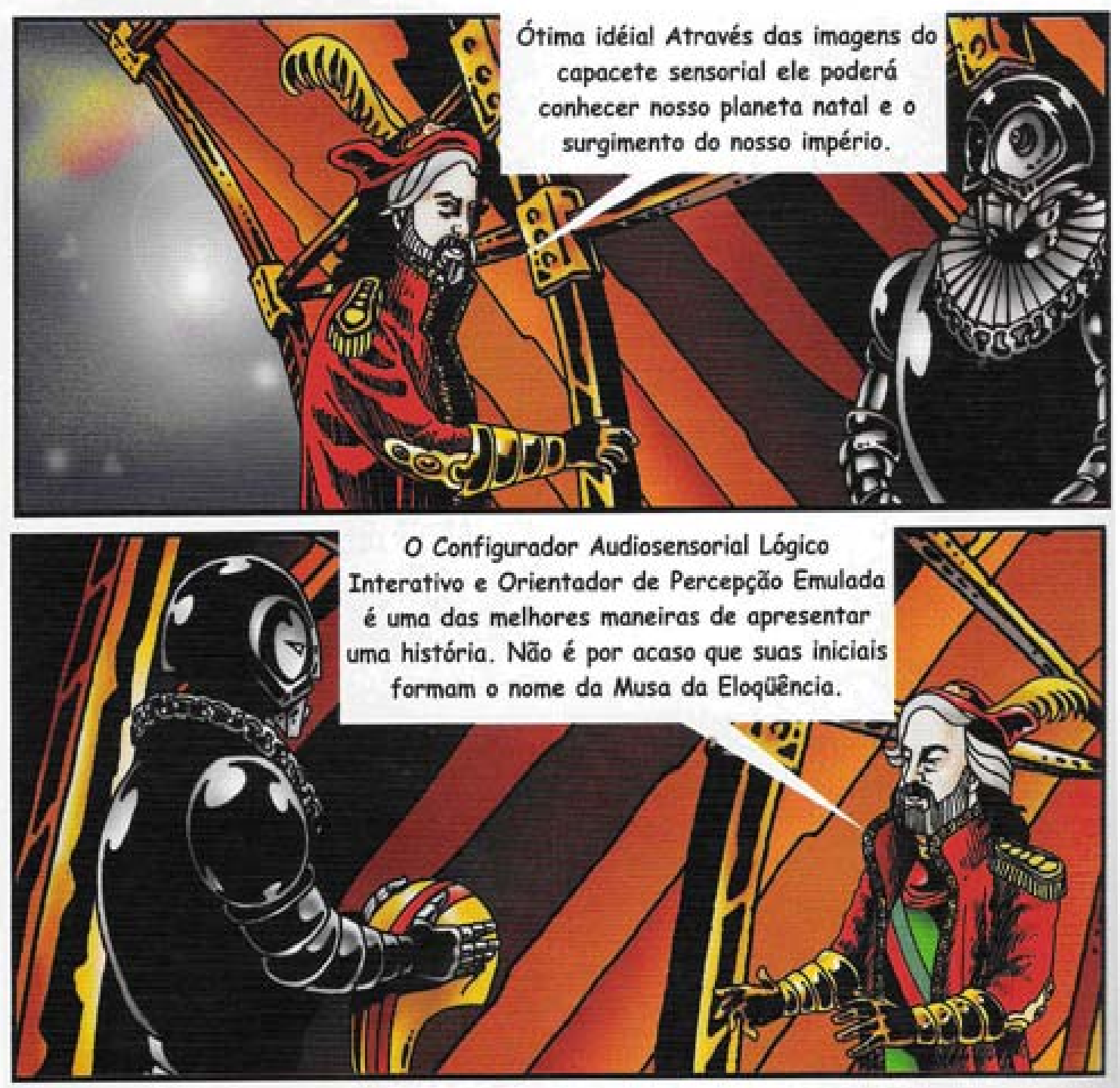

Fig. 40 - A linguagem, como em outros momentos de discurso direto, é cheia de referências tecnológicas e futuristas.

Quando se inicia a narrativa do passado, as ilustrações tornam-se então, mais escuras e o fundo borrado, numa composição cenográfica que lembra imagens distorcidas (Fig. 41). 


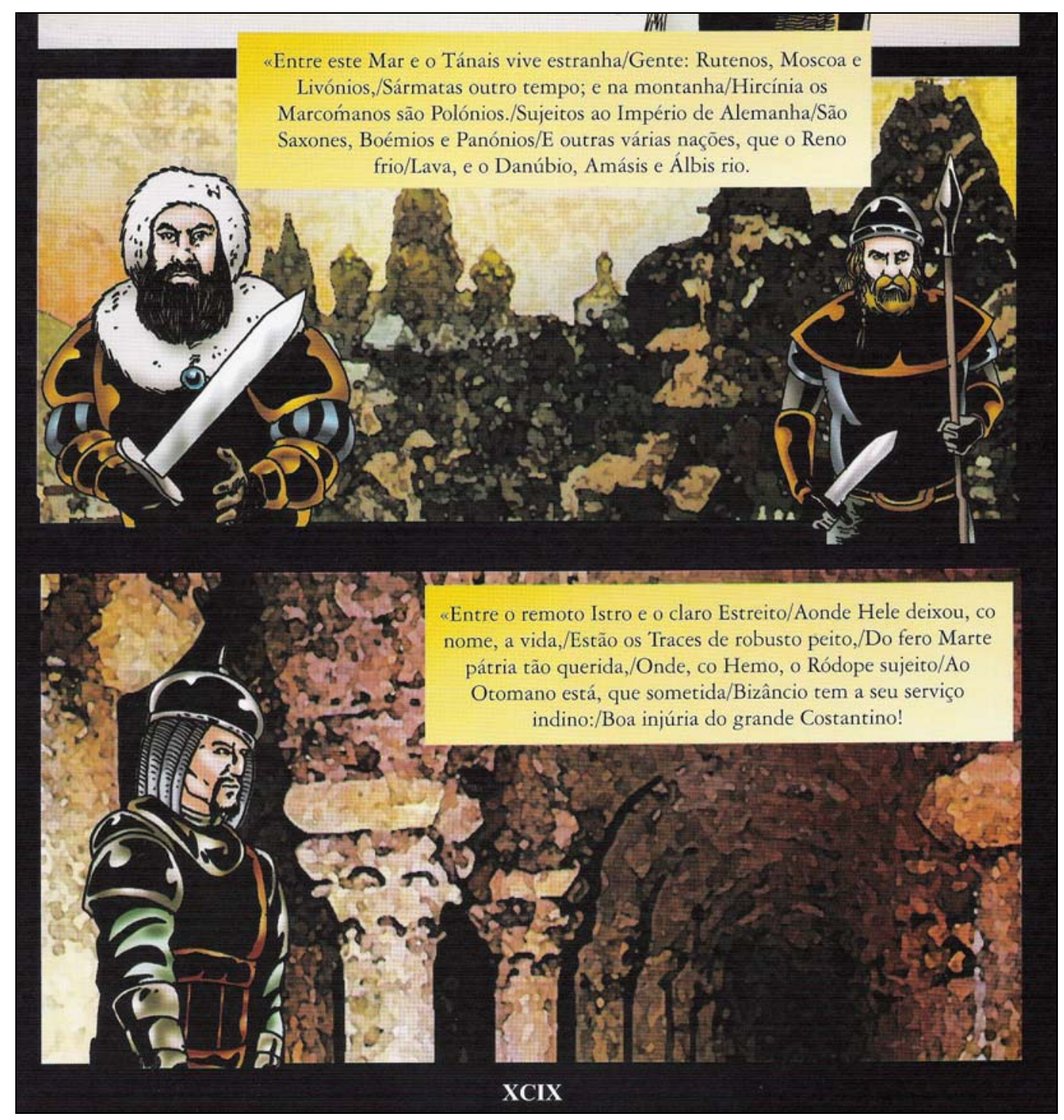

Fig. 41 - As figuras em primeiro plano são representadas de forma nítida, enquanto o cenário se apresenta borrado.

A identidade visual de Lusíadas 2500 remete para o caráter clássico da obra de Camões, ressoando nos traços bem cuidados, a grandiosidade dos cenários e acontecimentos descritos. Não se trata apenas do espaço sideral, mas de um espaço exuberante e misterioso, assim como os mares navegados pelas naus portuguesas na obra original. A introdução de novos elementos na narrativa, como o subtexto futurista e os 
diálogos, provoca uma maior mudança no texto-base que, apesar de ser mantido no original, demonstra inserir-se em um novo contexto.

A pouca exploração dos recursos dos quadrinhos, da interação entre as linguagens, contudo, cria uma obra que aponta mais para um livro ilustrado do que uma história em quadrinhos. Mesmo assim, Lusíadas 2500 traz inovações que permitem uma maior aproximação do leitor moderno, acostumado com a visualidade, a ficção científica, e assim

por diante. Outro aspecto importante a ser observado é que, por meio da mudança de gênero, dos cenários exuberantes, do diálogo inserido na épica Camoniana, temos uma maior inserção do aspecto lúdico e do espaço para a interação com a obra original, na medida em que, para a compreensão da obra no novo contexto proposto, precisamos fazer a ponte entre os versos de Camões e o espaço futurista.

\section{b) Branca de Neve num jogo de montar}

Na recente adaptação (2007) do clássico dos irmãos Grimm, Branca de Neve, feita por Rafael Coutinho para o álbum Irmãos Grimm em Quadrinhos, temos um bom exemplo de como a linguagem não-verbal e os recursos dos quadrinhos podem ajudar a contar a estória, trazendo novos elementos à mesma. Não se trata aqui de inserir uma dimensão narrativa diferente, como em Lusíadas 2500, com seus cenários futuristas e personagens interplanetários, mas sim de dirigir um novo olhar à obra original, recontando-a de forma 
própria, tirando mais proveito da linguagem não-verbal e da visualidade inerente aos quadrinhos.

A adaptação de Coutinho é feita basicamente por meio da linguagem não-verbal, que reinterpreta e simplifica a obra original de Grimm. Temos todos os elementos da obra base: Branca de Neve, os anões, as tentativas frustradas da madrasta malvada, o final feliz, só que apresentados de forma própria, como numa montagem de figuras. A HQ, que é feita em preto e branco (assim como todo o álbum), traz desenhos num traço caricatural e simplificado. As vinhetas se espalham na página de maneira uniforme, em doze quadros de igual tamanho.

O tipo de escolha das cenas desenhadas assemelha-se a uma forma de quebracabeça, em que precisamos unir os elementos por meio de nexos próprios até obtermos uma compreensão total do enredo que, por sua vez, remete ao texto-base. Daí ser uma tarefa menos difícil, já que são apresentados aspectos diretamente ligados à obra original e que são amplamente conhecidos: espelho mágico, madrasta malvada, coração, anões, etc. A constante divulgação e atualização de narrativas como a de Branca de Neve, Chapeuzinho Vermelho e outras, aliás, deve-se ao fato de que, como afirma Coelho (1987, p.9), o maravilhoso, o imaginário e o fantástico não são mais vistos apenas como pura fantasia, mas sim como"portas que se abrem para determinadas verdades humanas [...] O que nelas parece apenas 'infantil', divertido ou absurdo, na verdade carrega uma significativa herança de sentidos ocultos e essenciais para a nossa vida”. 
No quadrinho de Coutinho, a linguagem verbal surge de forma complementar/explicativa à linguagem não verbal, o que pode ser percebido pela preponderância da linguagem não-verbal. Assim, as legendas e os balões são usados apenas em momentos pontuais e de uma forma bastante econômica. O conto de Grimm é narrado na HQ como um mosaico de ilustrações, num exercício de recortes e colagens, que remete mais a um álbum de figurinhas do que propriamente aos quadrinhos. $\mathrm{O}$ pouco uso de recursos como balões, legendas, exploração das vinhetas, etc., dá a sensação de uma obra mais estática do que dinâmica.

Na $1^{\text {a }}$ página temos o nascimento de Branca de Neve. Os desenhos que compõem o quadro trazem elementos reconhecíveis por quem já teve contato com o texto-base: um castelo, uma mulher costurando, um dedo furado, uma gota de sangue, um bebê, que após esse trajeto imagético, deduzimos ser Branca de Neve. A linguagem verbal, como em toda a obra, é mínima (Fig 42).

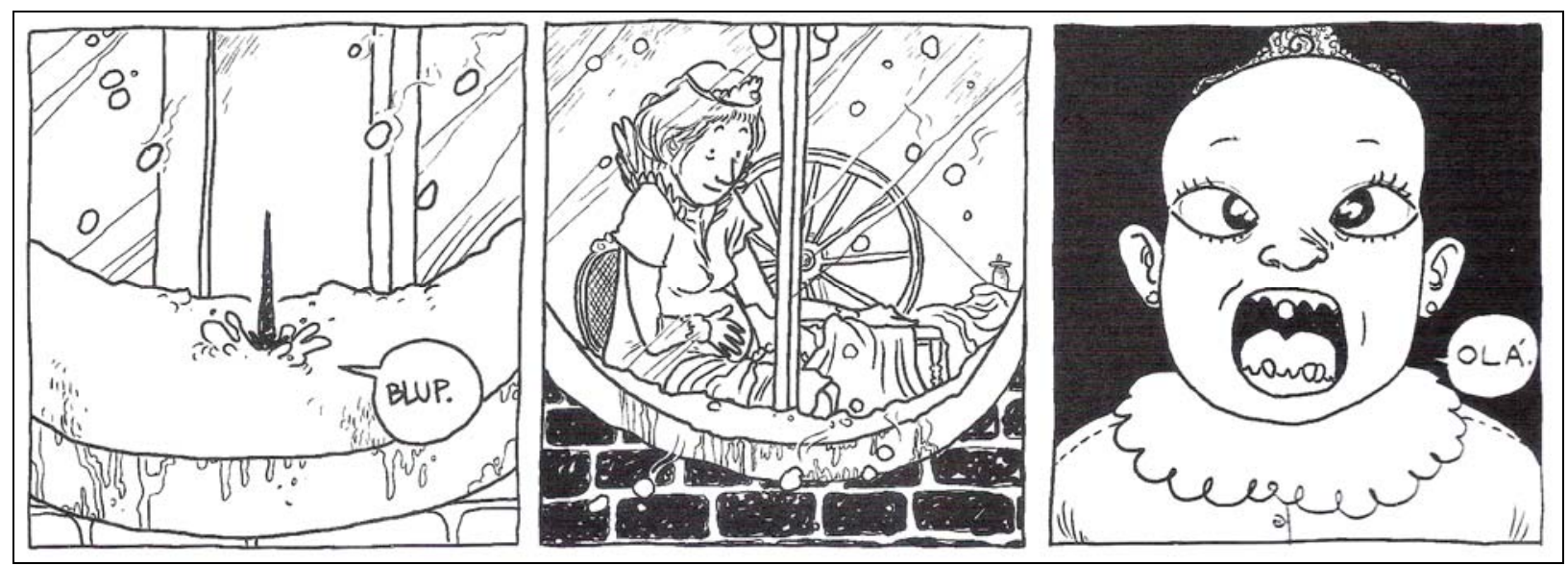

Fig. 42 Na última seqüência da página, as ilustrações resumem o nascimento de Branca de Neve: o sangue que cai na neve (sonorizado pela onomatopéia “blup”), a mulher com a mão na barriga e o bebê. O cumprimento do bebê introduz um elemento de estranhamento (de insólito), por vir expresso de uma maneira direta demais para o contexto e por estar direcionado ao leitor. 
A estória se desenrola com economia de linguagens (verbal e não-verbal), e se apresenta na forma de um esquema. É dessa forma que é mostrada a morte da mãe de Branca e a coroação da madrasta como a nova rainha. (Fig. 43). O diálogo entre a madrasta e o espelho é outro exemplo da economia de linguagens: a madrasta pergunta apenas “quem?” e o espelho responde “tu”, ilustrando de forma sucinta o célebre diálogo: “Espelho, espelho meu...”.

Nesse trecho, há o uso de um recurso que reforça o caráter esquemático e simplificado da narrativa: a repetição de figuras. O rosto da madrasta surge em dois momentos de maneira praticamente igual. É apenas a alteração de pequenos detalhes na segunda imagem, como a coroa na cabeça, os cabelos alinhados e a gola da roupa, que revelam a mudança temporal, o que vem expresso de maneira irônica pela linguagem verbal: antes ela era ninguém, mas depois da morte da mãe de Branca ela assume o status de Madrasta-rainha. Tal forma de composição permite acompanhar o que muda e o que permanece em cada cena representada, criando assim a seqüencialidade dos quadrinhos. Contudo, a seqüencialidade, apesar de presente na obra, é quase que totalmente diluída pela simplificação dos traços e da configuração visual, surgindo apenas em pequenos detalhes. Daí a impressão de estarmos diante de uma obra mais estática do que dinâmica, não revelando agilidade ou movimento na maioria das vezes. É como se a câmera focalizasse aspectos e detalhes de uma mesma cena, com pouca enfatização para os saltos temporais. 


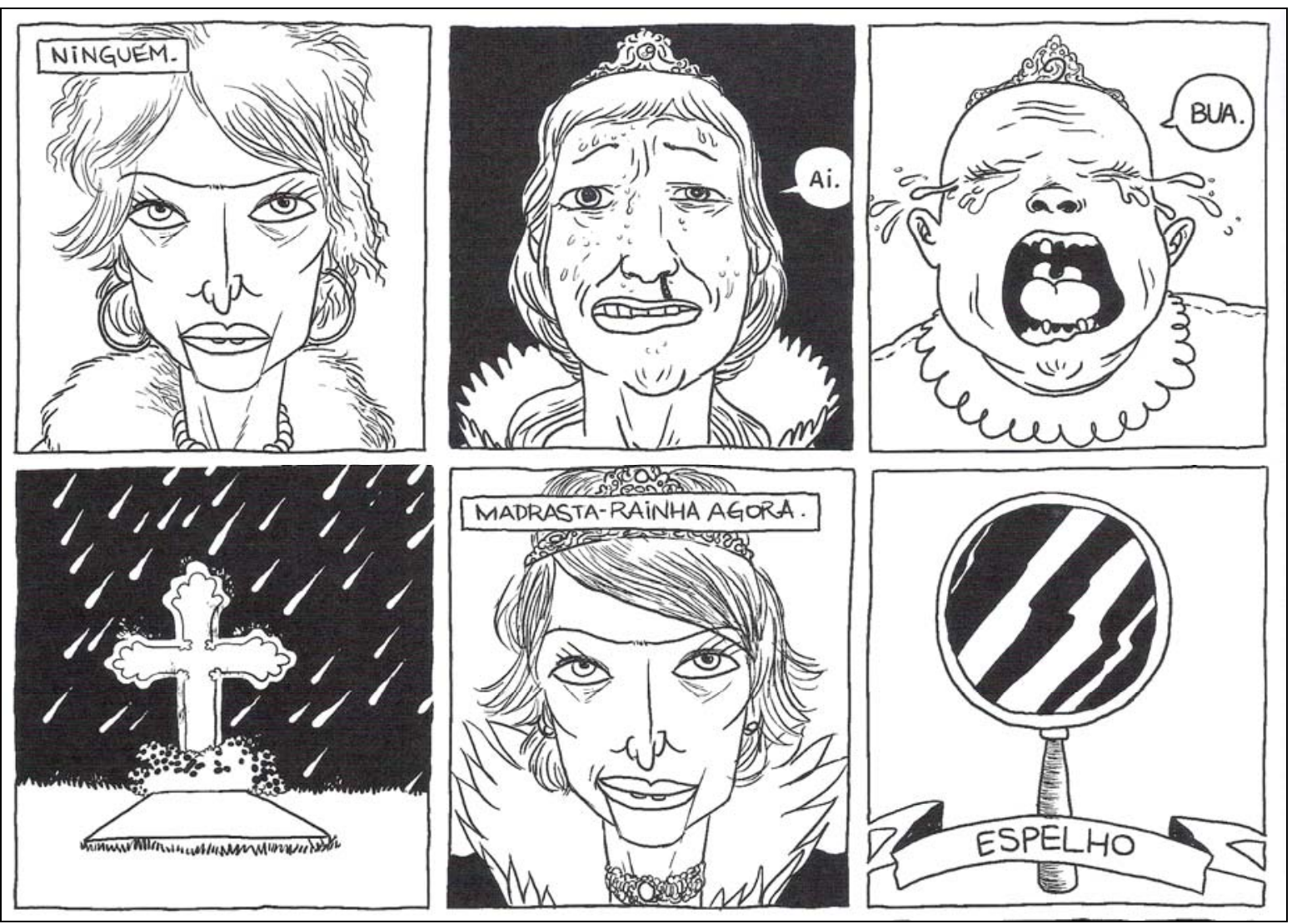

Fig. 43 - Pela disposição das figuras, parecemos estar, em determinados trechos, diante de um jogo de encaixe, em que cada peça ocupa um lugar-chave para a compreensão da obra.

O crescimento de Branca até se tornar uma moça que rivalizava em beleza com a madrasta é contado com um rápido jogo de ilustrações (Fig. 44). A figura de um cachorrinho poodle no meio da seqüência é um elemento novo acrescentado à estória e ajuda a reforçar, no contexto, a hostilidade da Madrasta, a dona do cachorro, em relação à Branca de Neve. 

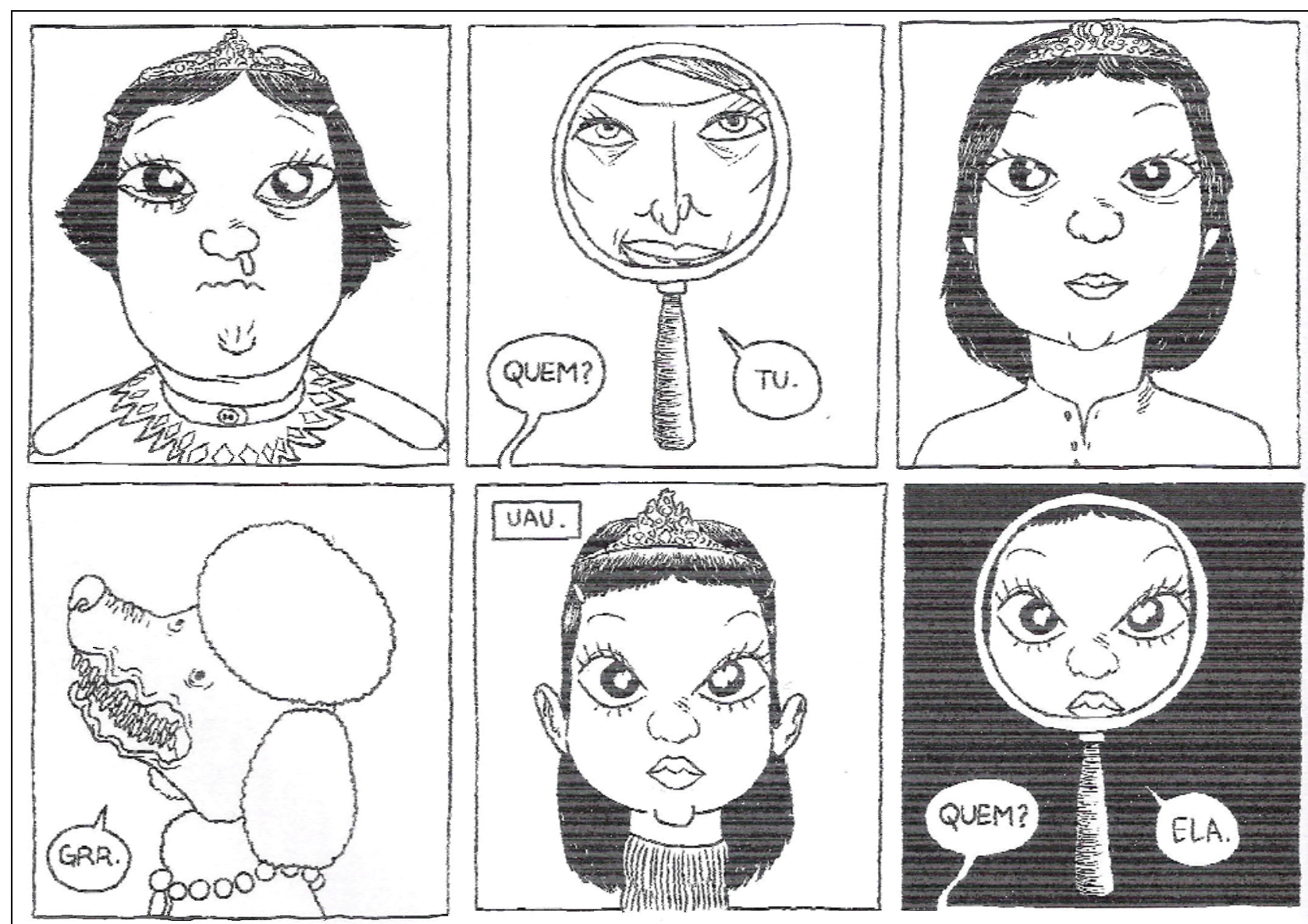

Fig. 44 - A linguagem não-verbal, assim como a verbal, é utilizada de forma econômica, mostrando apenas o que é necessário para que compreendamos a estória.

O diagrama é utilizado para representar determinados elementos, dar um caráter mais explicativo e até mesmo cômico (Fig. 45). Assim, temos desde um mapa mostrando onde fica o quarto da princesa, até as formas de atuação dos objetos maléficos usados pela rainha para matar Branca: o “corpete do mal” e o "pente envenenado". 

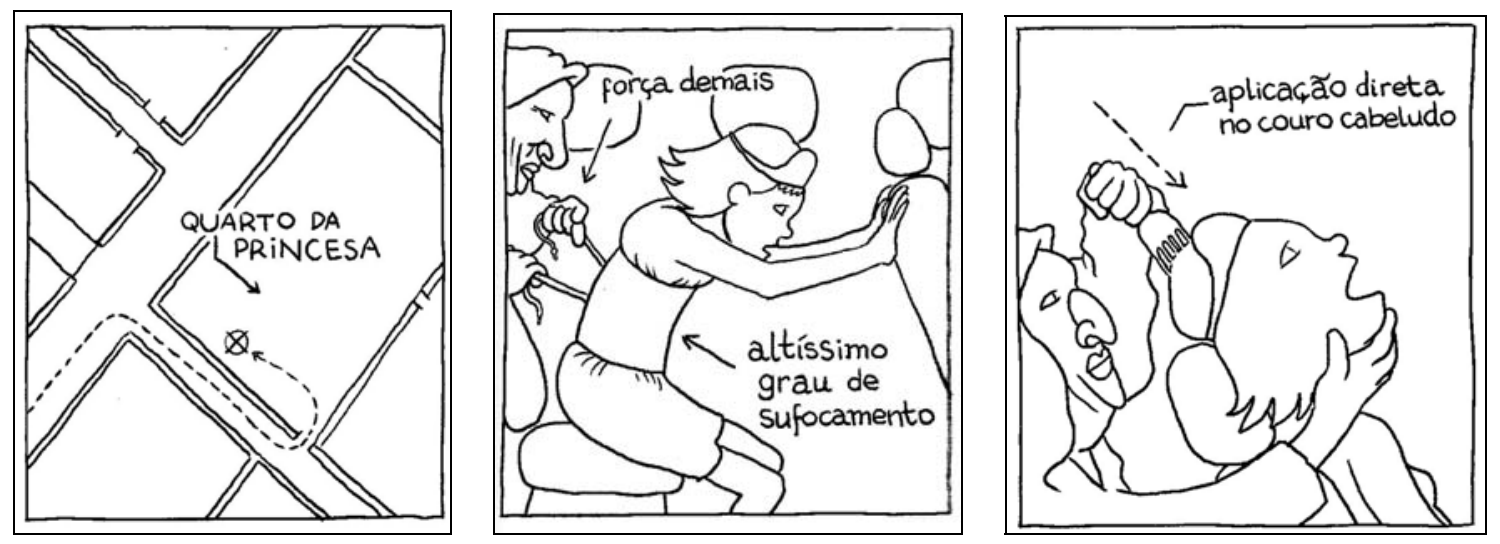

Fig. 45 - O diagrama, além do caráter explicativo, tem um efeito humorístico na narrativa, o que é ampliado pelas informações verbais contidas nele.

Outro elemento que ajuda a dar a idéia de uma obra estática, com pouco movimento, é a forma de focalização das imagens: há um predomínio de close up, mostrando rostos e detalhes das figuras. É como se estivéssemos diante de um mural fotográfico, em que partes das cenas são mostradas, uma após a outra, construindo um todo coerente e coeso. No exemplo a seguir, temos a seqüência de quadros que nos mostra a ordem da madrasta para o caçador: matar Branca e trazer seu coração e seus pulmões. Mais uma vez temos o recurso do uso repetido de figuras com pequenas mudanças nas cenas: o rosto do caçador, mostrado em close em dois momentos da seqüência, não se altera, havendo uma repetição da mesma figura. Na verdade, o que importa é a colagem, construindo nexos a partir da união dos desenhos (Fig. 46). 


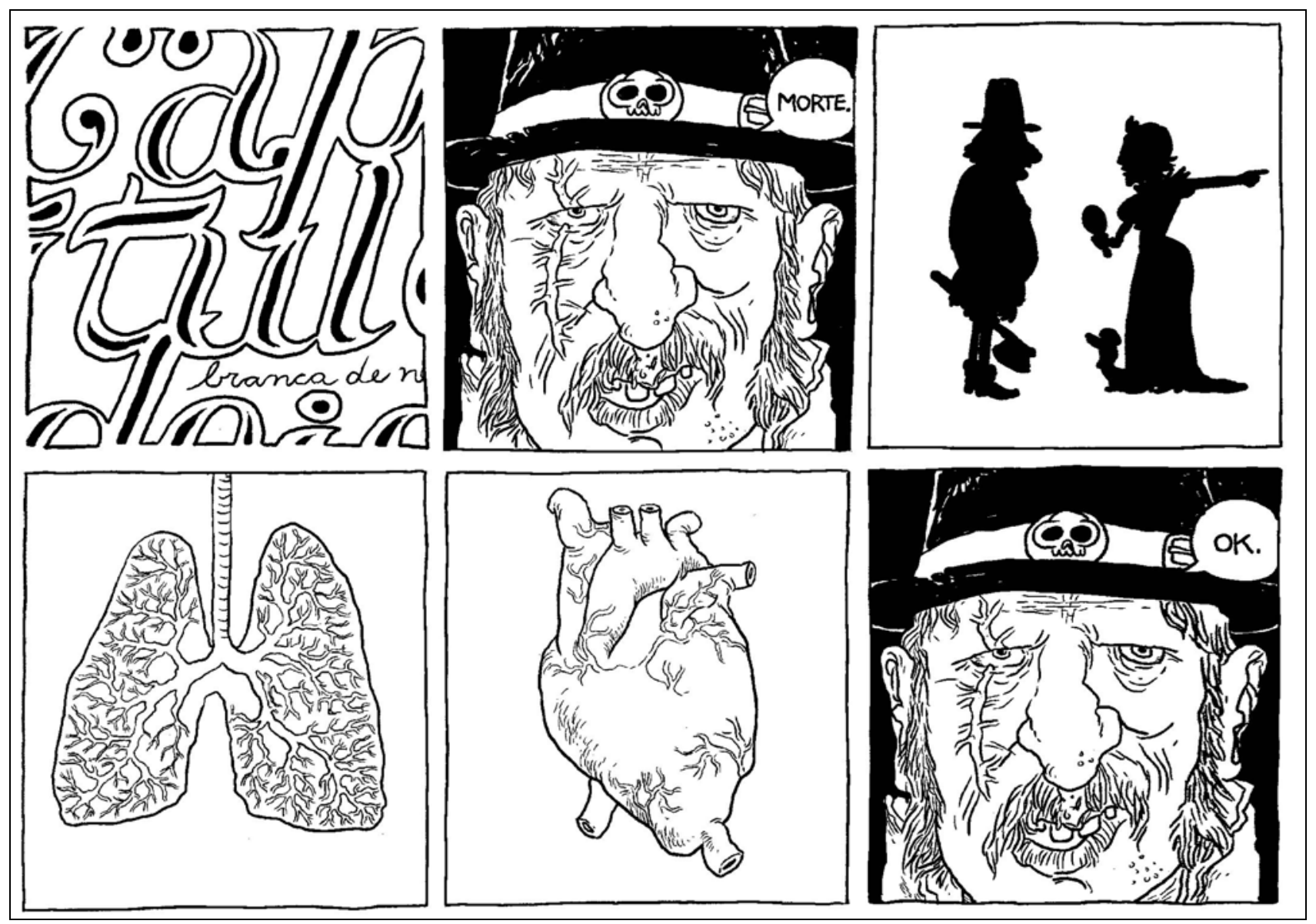

Fig. 46 - As figuras do pulmão e do coração ajudam a explicar o enredo, na medida em que fazem parte da narrativa original.

Quando Branca se casa com o príncipe, também é uma seqüência simplificada de desenhos que ilustra o fato esquematicamente (Fig. 47). Aqui não temos uma ênfase na passagem do tempo, nem há uma referencia explicita de que se trata do casamento de Branca. São os aspectos isolados da cena como os bonequinhos no bolo, os parabéns dos animais, além do conhecimento que temos da obra-base, que nos auxilia a compreender a cena. O caráter inusitado da cena fica por conta dos parabéns dados pelos animais e por um coração, o que pode ter várias interpretações: coração enquanto órgão, do porco ou da própria Branca, numa expressão humorística, ou enquanto manifestação da paixão entre ela 
e o príncipe. A figura do cachorro comendo a maçã envenenada, no meio da seqüência, funciona como um corte na cena, um desvio da "câmera", e mostra que o animal de estimação da madrasta também foi castigado.
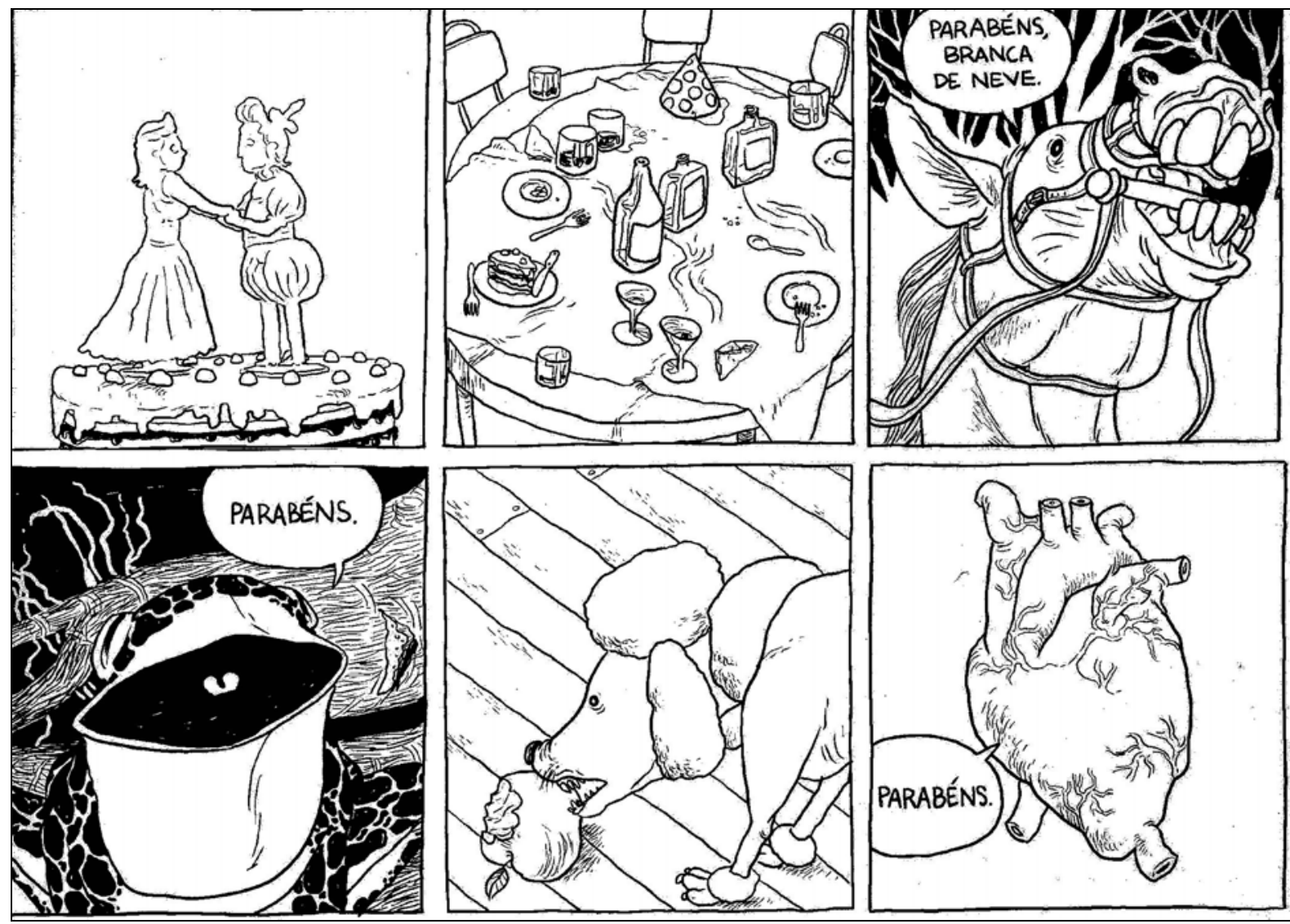

Fig. 47 - Os animais falantes funcionam como uma referência, um diálogo, com outras versões do conto de Grimm, sobretudo as feitas pela Disney, em que Branca compactua e é ajudada pelos animais da floresta. Na adaptação de Coutinho, a fala dos bichos parece acentuar o efeito esquemático e inusitado, em que todos os elementos integrantes da estória têm sua participação no grande final.

A Madrasta também é castigada com os "sapatos de chumbo incandescente”. A expressão satírica remete ao próprio conto dos Grimm, em que os sapatos são esquentados no fogo e a madrasta é obrigada a calçá-los. O diálogo final entre Branca de Neve e a 
Madrasta é apresentado de forma reduzida (Fig. 48). Apesar de ser um momento trágico para a rainha, quando ela é obrigada a calçar os sapatos queimando, a forma simplificada como a seqüência é representada esvazia o episódio de sua dramaticidade. O fim da estória é representado de maneira bem simples, em consonância com o ritmo de toda a obra.

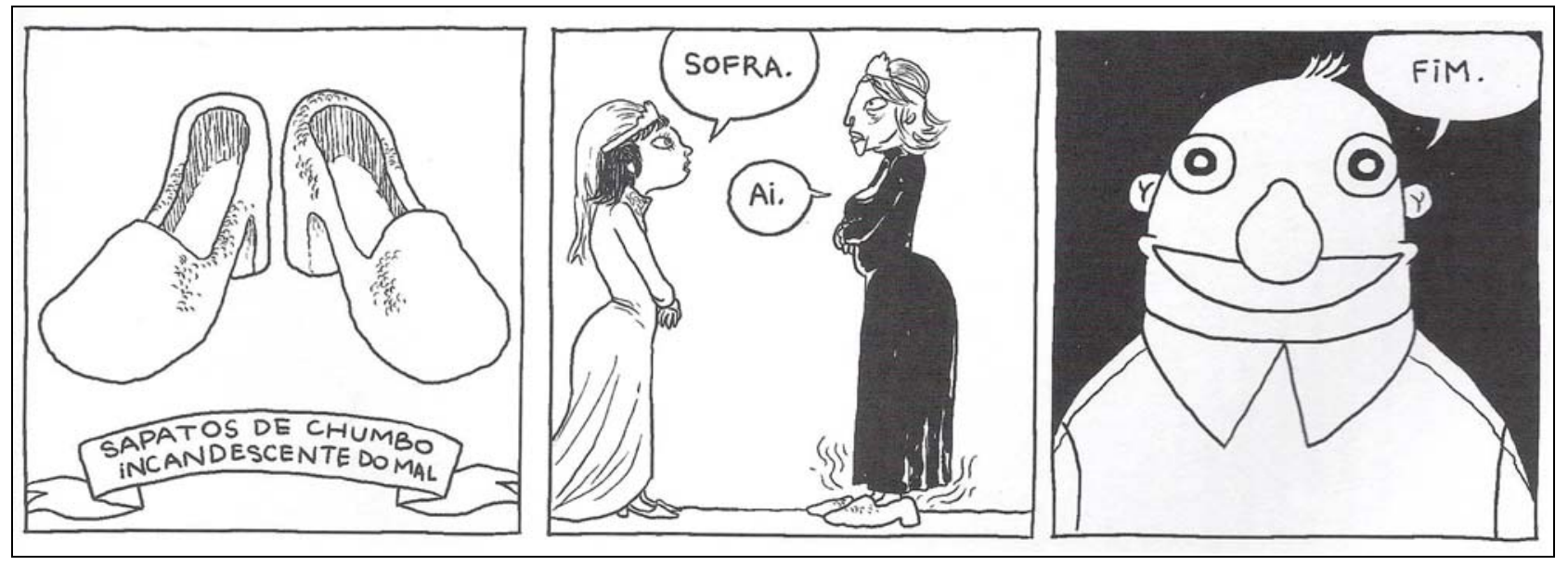

Fig. 48 - O quadrinho, feito todo em preto e branco, praticamente não explora elementos de composição como as sombras e contraste entre claro-escuro, recursos que costumam ser usados para dar idéia de volume, movimento e até mesmo dramaticidade, elementos esses que, de uma forma geral, não estão presentes na obra.

O esquema é a principal ferramenta de composição da obra, cuja ordem e maneira como as ilustrações são reveladas permitem a compreensão do enredo que, por sua vez, remete ao texto original dos Grimm. A forma de representação, como num álbum de figuras, um mural de colagens favorece o aspecto lúdico. Na HQ vemos um esvaziamento da dramaticidade da obra original e o que se propõem é um jogo de montar, um quebracabeças, uma “adivinha”, apesar de se relacionar com informações conhecidas. 


\subsubsection{Diálogo para novas obras}

Determinadas obras desenvolvidas nos quadrinhos procuram estabelecer uma outra forma de interação com a literatura, aproveitando o material produzido nela para criar novas elaborações narrativas. Não se trata, portanto, de adaptações, mas sim da utilização do material literário para criar diferentes narrativas. Essa forma de inter-relacionamento é uma das características mais presentes na produção artística do nosso tempo.

Se atentarmos para outros suportes como o cinema, encontramos diversos exemplos de obras que realizam um diálogo entre si. Animações como Sherek, em que o famoso ogro atua com personagens de fábulas e contos de fada, como os três porquinhos, Pinóquio, Branca de Neve, etc., ou Deu a louca na Chapeuzinho, com uma nova proposta para o enredo do célebre conto de Grimm, demonstram as várias possibilidades de interação entre obras e meios de comunicação.

O que ocorre com o texto-base é que, diferente dos casos anteriores, não se apresenta mais na sua forma original; o que temos são diferentes construções narrativas, em que determinados elementos da obra original ainda podem ser identificados (personagens, cenários, etc.), mas surgem agora em uma nova chave, com diferentes desenvolvimentos e desfechos.

Podemos encontrar desde obras que parodiam as originais, até aquelas que citam, direta ou indiretamente, fazem alusão ou interagem de outras maneiras com elementos do 
texto literário. Em Língua Portuguesa, muitas obras produzidas por meio do diálogo com a literatura se revelam como parodizações, reforçando, portanto, o humor na forma de organização e apresentação de seus elementos. É o que ocorre nos primeiros exemplos destacados a seguir, em que os autores dialogam com grandes clássicos da literatura, como Patinho Feio, Branca de Neve e outros.

\section{a) Fábulas e fadas na mira do humor}

O humor tem sido uma importante ferramenta para o estabelecimento de diálogos entre quadrinhos e literatura. Dentre as teorias tradicionais sobre o humor, podemos destacar aquelas que dizem respeito à quebra de expectativas (incongruência), em que o riso é desencadeado por algo inesperado, a ruptura de alguma norma ou preceito:

“[...] não é, simplesmente, a presença de elementos incongruentes a causa do efeito cômico, pois há uma coerência interna na organização desses elementos. [...] a graça surge quando elementos incongruentes presentes no texto opõem-se aos modelos cognitivos interiorizados pelo ouvinte/leitor”. (SOUZA, 1997, p.7)

Vale destacar que, os modelos interiorizados pelos receptores fazem parte de um acervo coletivo, e o cômico, por sua vez, também será resultado de um conhecimento compartilhado pela sociedade (Bergson 1987 apud SOUZA, 1997) ${ }^{1}$.

A paródia, por seu lado, uma das expressões do cômico e forma de diálogo entre os textos que serão destacados a seguir, expressa-se por meio da desconstrução da obra original, subvertendo-a em busca da diferença. Assim, a paródia, em sua relação com o

\footnotetext{
${ }^{1}$ BERGSON, Henri. O Riso: Ensaio sobre a significação do cômico. Rio de Janeiro: Ed. Zahar, 1987.
} 
texto-base, “subverte seu enunciado e desqualifica sua enunciação, propondo uma outra enunciação substituta, contrária, diferente. No entanto, essa diferença articula-se sobre uma semelhança” (DISCINI, 2002, p.26).

Também é importante ressaltar que a paródia trabalha com o conhecimento prévio do receptor da obra que está sendo parodiada. No caso específico desse estudo, destacamos obras que remetem a fábulas e contos de fadas, textos, portanto, de conhecimento de grande parte do público, e que continuam presentes no mundo atual, sendo re-escritas e reelaboradas de diferentes maneiras e em meios diversos.

A obra Patinho Feio de Spacca, realizada na década de 90 para a revista "Níquel Náusea”, traz em si as marcas do humor, reveladas por seus traços caricaturais e pelo enredo nada convencional, que se constrói por meio de parodização do texto original de Christian Andersen. Já de início, vemos a figura do pato em close. Alguns elementos acentuam o tom satírico da narrativa, como os enormes dentes do pato (fato inusitado) e as onomatopéias da última vinheta, indiciando que o espelho se quebrou devido à feiúra do pato (Fig. 49). 


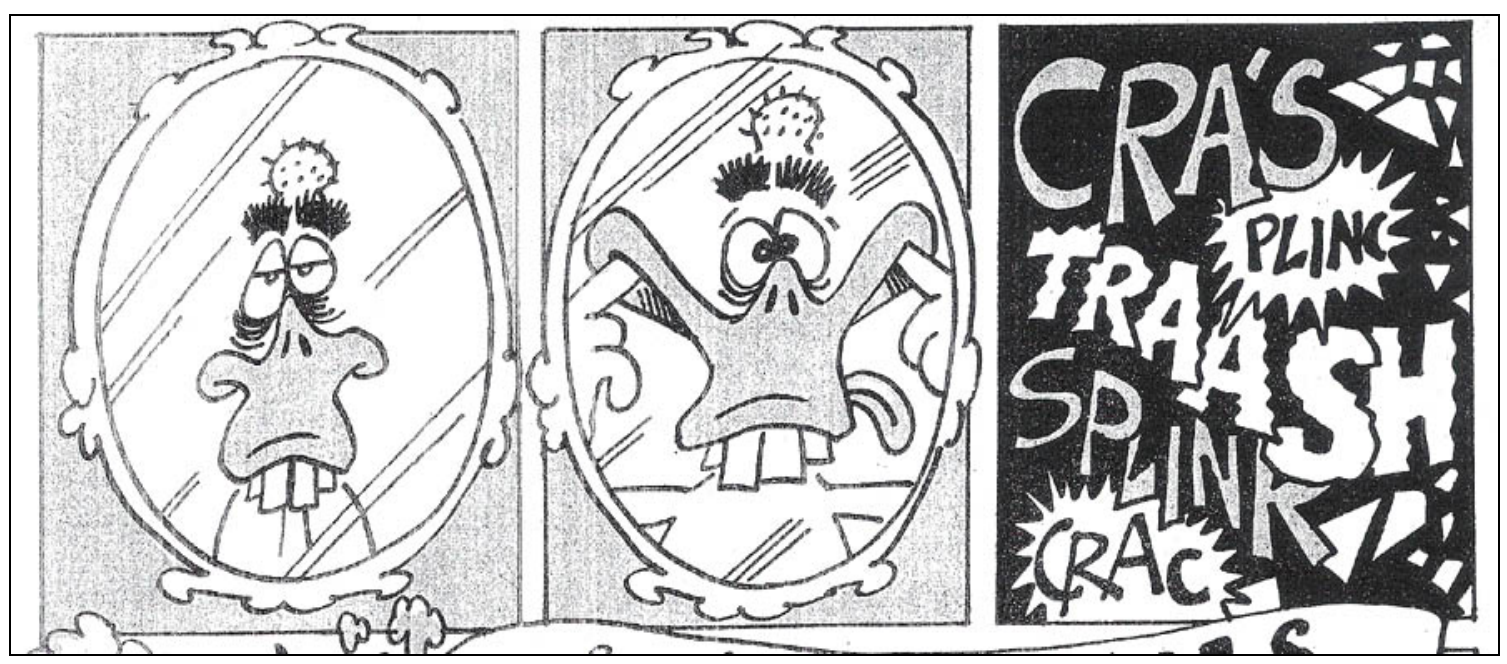

Fig. 49 - As onomatopéias do último quadro sonorizam a quebra do espelho. A onomatopéia é um recurso bastante utilizado em representações gráficas. Geralmente as convencionalmente usadas nos quadrinhos descendem de verbos da língua inglesa, como crack ou crac (do verbo to crash: quebrar, rachar), sniff (do verbo to sniff: cheirar), split (do verbo to split: dividir ao meio), etc.

O uso da referência em latim Patus horribilis para designar o pato feio, juntamente com o título da obra, amplia o efeito humorístico, pois remete às nomenclaturas exibidas pela ciência, o que parece apontar para o fato de existir realmente tal categoria científica. A estória mostra a vida do pato em meio aos outros patos retratados antropomorficamente. Seus corpos são esbeltos e transitam em casais enquanto o pato feio circula só e é constantemente satirizado pelos demais (Fig. 50). 


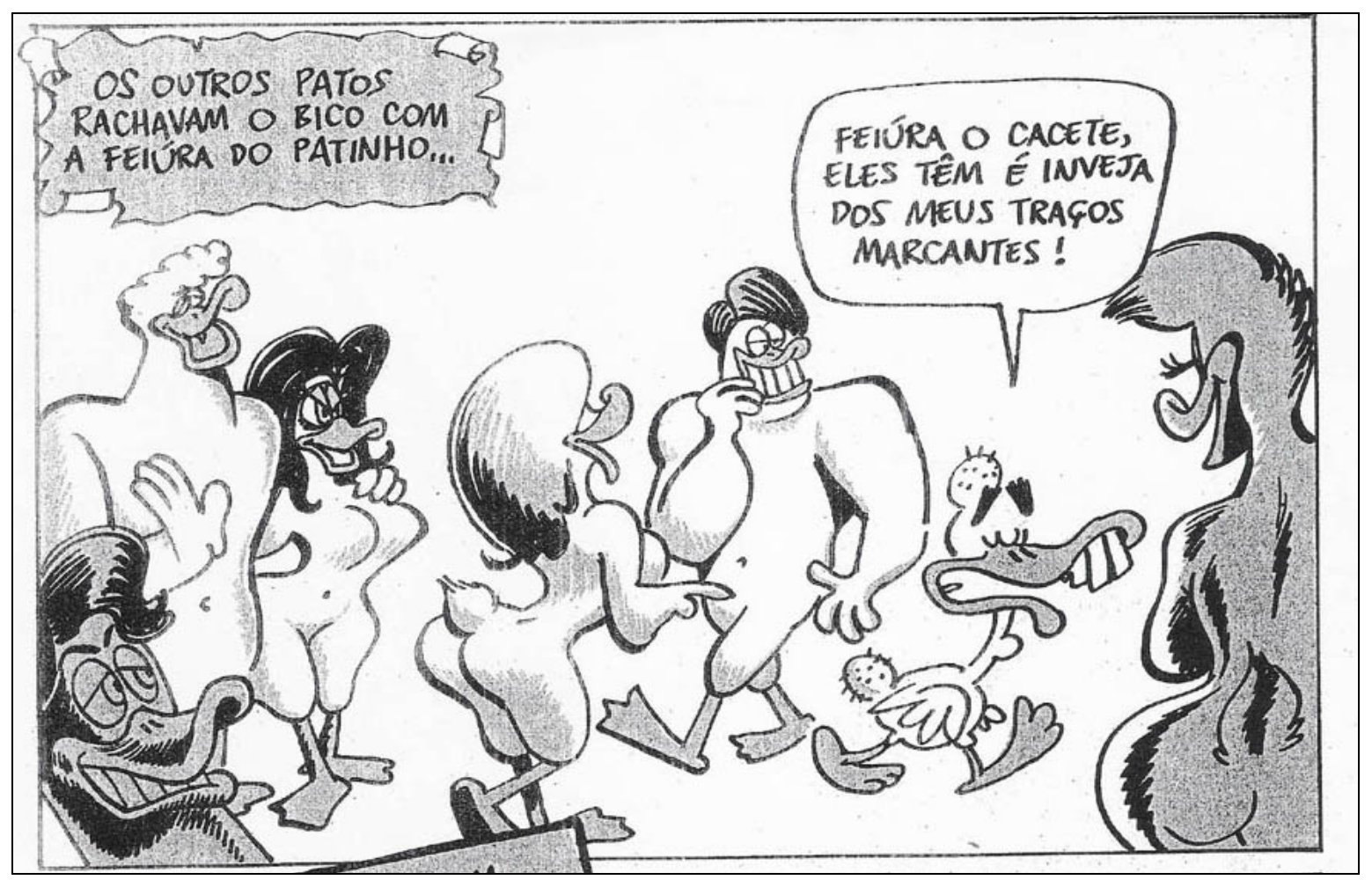

Fig. 50 - A forma como o Patinho procura ignorar a chacota dos demais é bastante irônica: ele acredita ser inveja dos seus traços marcantes, quando na verdade eles riem é da feiúra do pato mesmo.

Em determinado momento, o patinho feio estabelece um diálogo explícito com a obra de Andersen quando, ao se referir ao fato de que ao crescer se tornará um belo cisne, ressalta ter lido a fábula do autor. Tal informação é ironizada e contestada por outro pato, que retruca dizendo: “pato é pato. Cisne é cisne!”. A própria estória, por sua vez, parece confirmar a frase do pato quando, ao crescer o patinho feio, ao contrário do texto-base, se torna um “patão feio”. A ilustração mostra o pato desengonçado e triste chorando devido à sua feiúra. Ele, então, decide ir para o sul. Aqui temos uma referência ao pato não como o da fábula, que se transforma em um belo cisne, mas como uma ave de verdade, que migra para o sul (Fig. 51). 


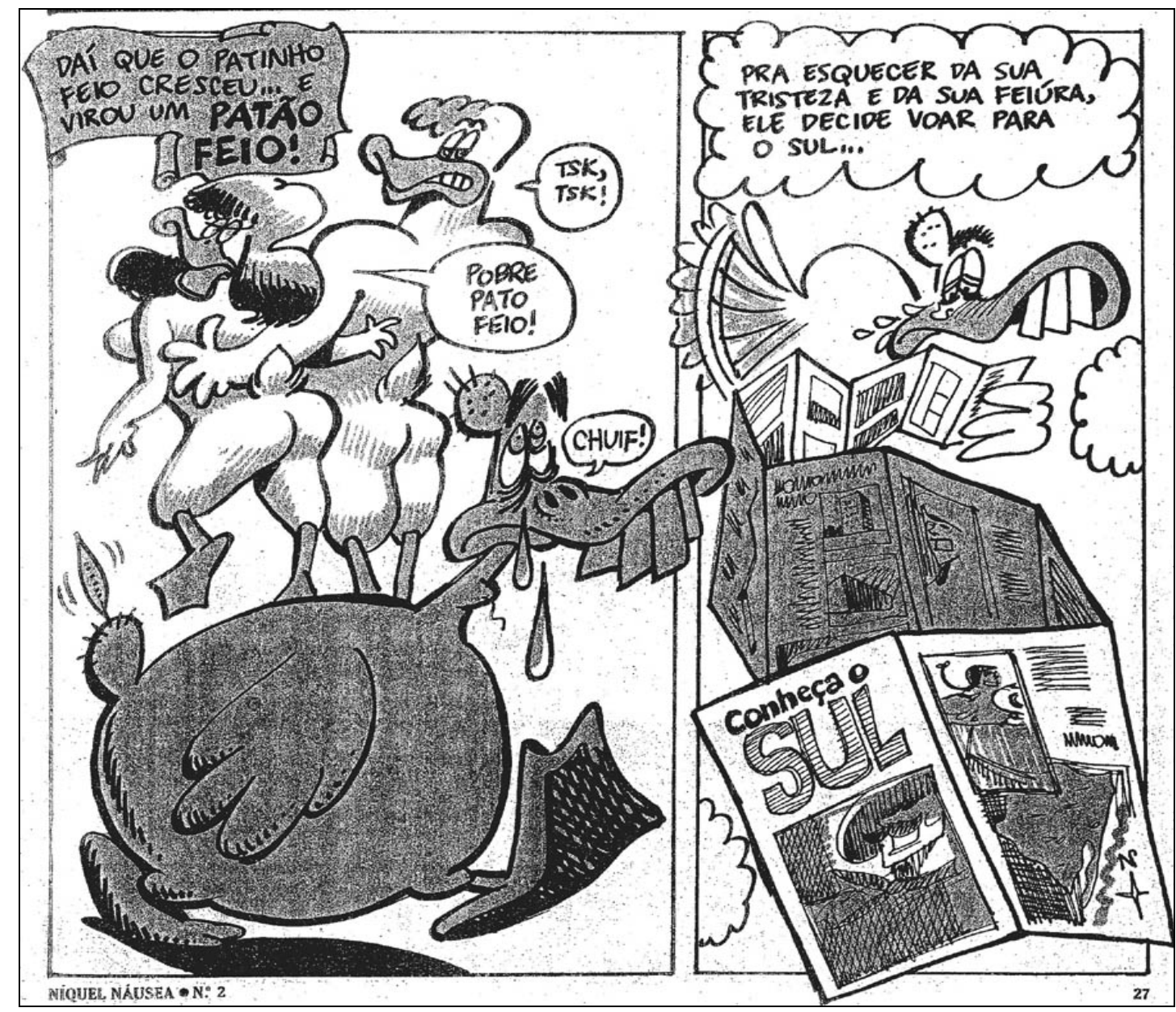

Fig 51 - A referencia irônica se dá quando vemos o pato consultando o que parece ser catálogos de viagem. Apesar de sua atitude remeter ao comportamento das aves (que migram para o sul), sua ação (se informando por meio de catálogos) e motivação (ir para o sul para esquecer a feiúra) são bem humanas.

Nos quadros seguintes é apresentado o destino final do patinho feio. Por meio de uma narrativa expressa mais pela linguagem não-verbal do que pela verbal, observamos o pato ser abatido por um caçador (Fig. 52). Os diferentes enquadramentos ajudam a dar mais dinamismo e dramaticidade à seqüência: as tomadas de baixo para cima, o close no pato, etc. 

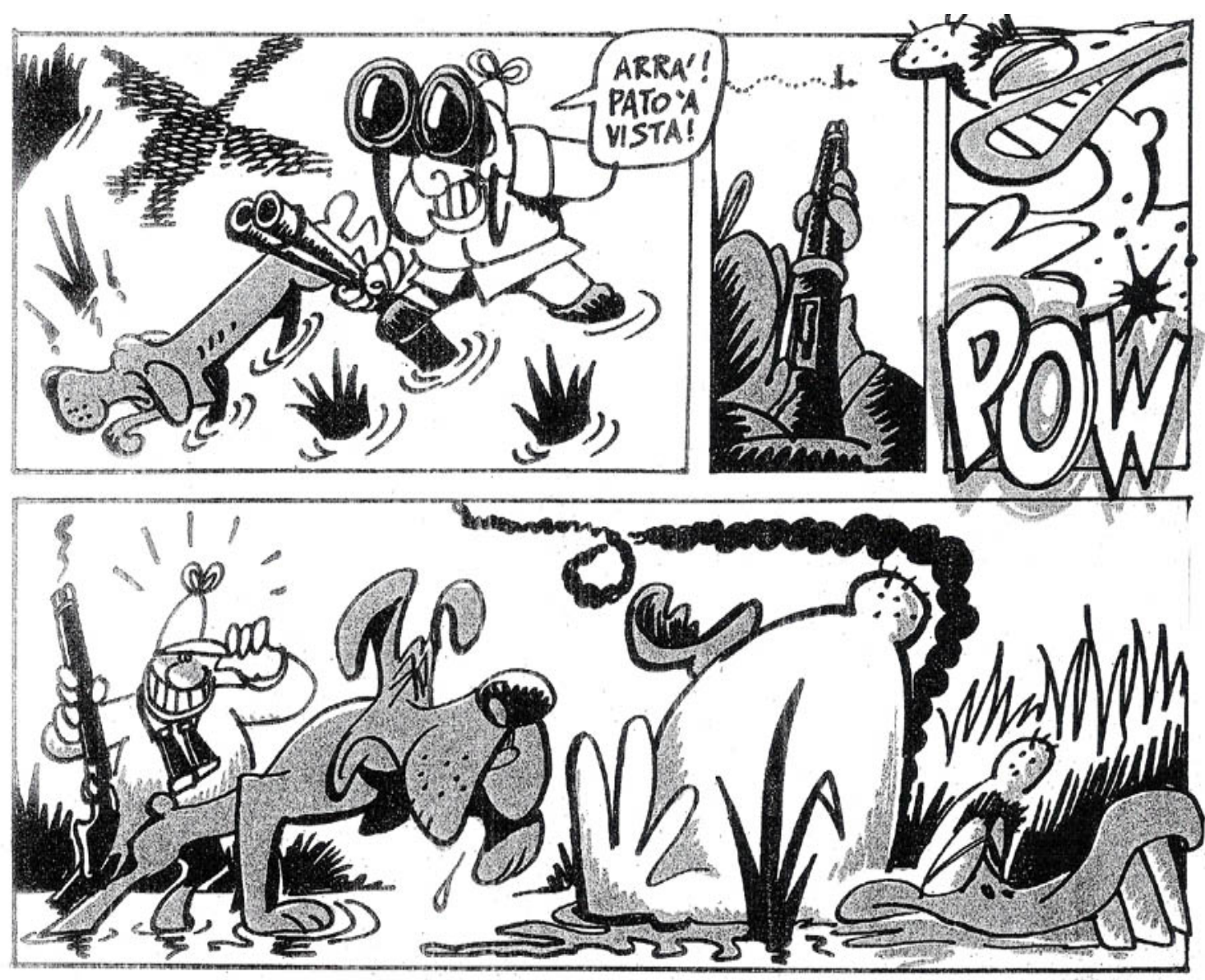

Fig. 52 - A expressão do caçador, com um sorriso de satisfação diante da caça abatida, na última vinheta, antecipa o riso "guloso" daqueles que vêem no pato uma "linda" refeição.

No último quadro, temos o desfecho tragicômico: na legenda podemos ler as palavras do narrador onisciente que pede para não lamentarmos a sorte do pato, pois somente naquele momento foi admirado pelo mundo "por seus atributos físicos"; a linguagem não-verbal complementa a mensagem com o desenho de um enorme pato assado numa bandeja, sendo admirado pelas pessoas em cena, que se dirigem ao pato e à sua cozinheira com vários elogios. Ao fundo do cenário, a imagem da carcaça da ave preparada (cabeça, penas, etc.) e de uma faca reforçam o aspecto trágico e ao mesmo tempo irônico da estória (fig. 53). 


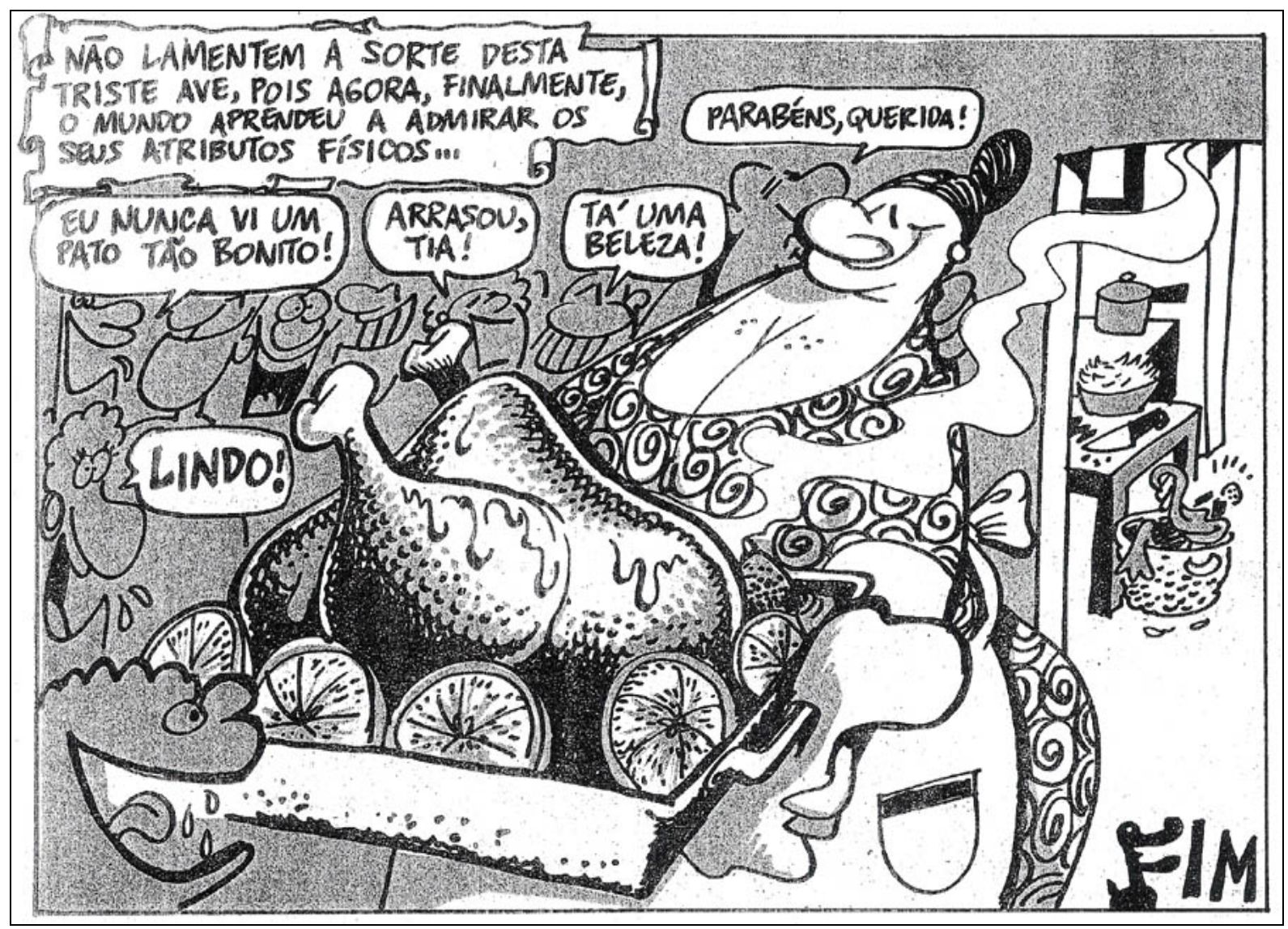

Fig. 53 - Em um só quadro são mostrados vários elementos que compõem o desfecho da narrativa: em primeiro plano e com destaque, a figura da cozinheira e do pato assado; à esquerda, no meio de um cenário acinzentado, o contorno de rostos que riem e admiram (gulosamente) o pato; à direita, num espaço iluminado (para podermos ver bem os elementos ao fundo) vemos os restos mortais do pato.

Como explica Gregorin Filho (1995), na obra O patinho feio, de Andersen, temos um confronto de valores e de transformações, em que a rejeição pelo grupo se dá pelo fato do pato "parecer” feio, o que causa sua conseqüente exclusão. Ele muda de lugar, mas ainda assim continua a ser rejeitado: “Esse deslocamento não causa grandes alterações na situação do sujeito, pois, tomando contato com novos e diferentes grupos, o seu 'parecer' faz com que o seu ‘ser’ não seja aceito” (idem, ibidem, p.30). Na versão de Spacca, o patinho também não é aceito por sua aparência, mas diferente do original, sua ida para outro local causa de fato uma grande alteração, na medida em que o pato é morto e, só 
assim, aceito e reconhecido como belo, porém em outra condição, não mais como ser integrante de um grupo, mas como alimento, pronto para ser devorado.

Estabelecendo um diálogo com a fábula de Andersen, Spacca cria outra narrativa, que questiona e inova a anterior. Seu humor, revelado pelo traço e pelo enredo, perpassa toda a obra. O lúdico também integra a composição da estória e permite a criação de nexos diferentes e inusitados entre o quadrinho e a obra-base.

Nas tiras de Gonsales, o humor também dá a tônica para o diálogo que ao autor estabelece com diversas obras clássicas. As personagens que transitam pelo universo da famosa personagem Níquel Náusea se relacionam com outras oriundas de estórias como Branca de Neve, Cinderela, etc. As tiras, formato utilizado por Gonsales para elaborar as estórias de Níquel Náusea e sua turma, possuem um espaço reduzido para mostrar a ação e seu desfecho. Elas “[...] apresentam o desenvolvimento de uma ação por meio de alguns momentos mais expressivos fixados em diversos quadrinhos. [...] O elemento de desvio do signo é, geralmente, um quadrinho. O desenlace ou disjunção se dá no último” (CAGNIN, 1975, p.193).

Observando-se a estrutura narrativa das tiras, podemos destacar alguns exemplos retirados da obra Gonsales que nos mostra o diálogo estabelecido pelo autor com textos clássicos da literatura. Numa de suas tiras, vemos uma referencia também à obra Patinho Feio de Andersen (Fig. 54). Dessa vez, o patinho é rejeitado quando pequeno, mas ao se tornar um cisne, usa seu enorme pescoço para espionar as conversas dos patinhos, que antes 
o deixavam de fora. O foco não é tanto a feiúra do pato, como no conto tradicional, mas as conversas das quais ele não podia participar. Com a mudança o patinho se torna apto não para ser aceito pelo grupo devido a sua aparência, mas para espioná-lo, ouvir o que falam, quer eles queiram ou não.

Em outra seqüência, a Bela Adormecida cai de sono, só que não por efeito de um feitiço, mas sim por ser picada pela mosca Tse-Tse, causadora da doença do sono (Fig. 55). A tira se encerra com um elemento do enredo original: o sono de Bela Adormecida, porém a causa agora é outra, a picada do inseto, que fica subentendido na linguagem verbal, sendo indiciada pela linguagem não-verbal: a mosca no primeiro quadro e depois voando próxima ao corpo de Bela Adormecida. Assim como na tira anterior, temos uma quebra de expectativa em relação à obra original, pois os fatos não acontecem como o previsto, de acordo com o conhecimento prévio que temos das obras tradicionais.
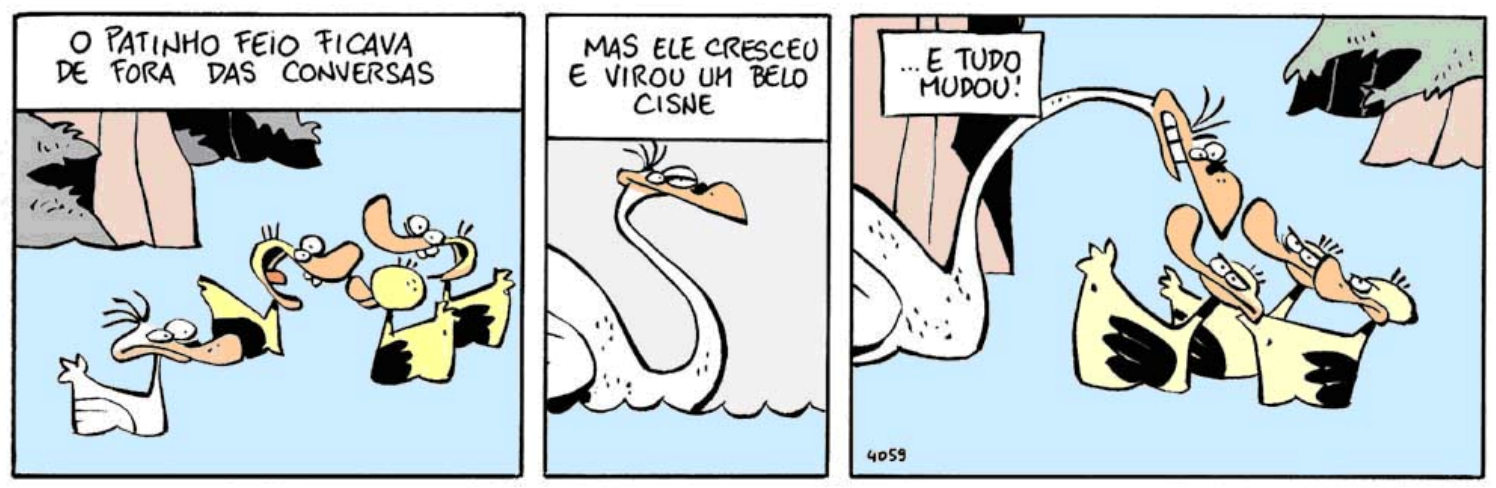

Fig. 54 - Os traços caricaturais são utilizados para retratar as personagens e os cenários. 


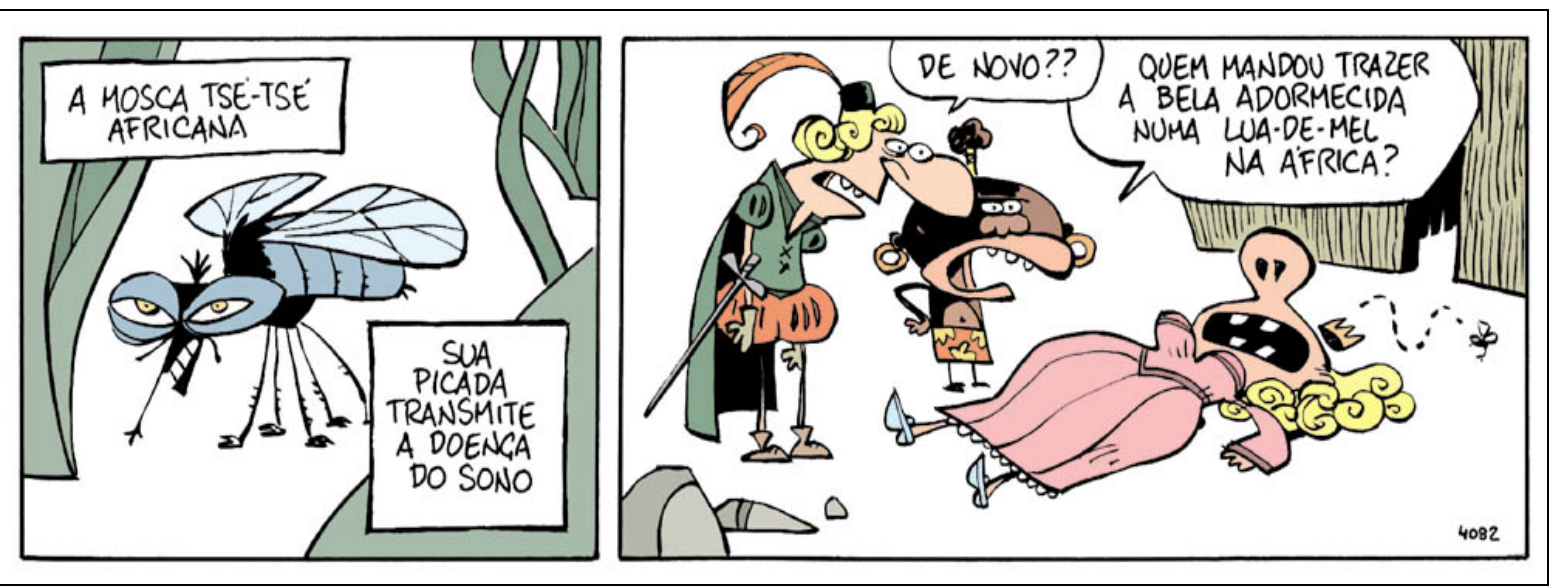

Fig. 55 - No primeiro quadro, somos apresentados à mosca tsé-tsé e a legenda traz a explicação de que ela transmite a doença do sono, informações que ajudarão a dar nexo ao desfecho do segundo quadro.

Dialogando com a estória de Os três porquinhos temos, em outra tira, a figura do lobo mau. Diferente do que ocorre na obra-base em que o lobo pega os porquinhos para comê-los, o lobo dessa versão revela um comportamento bem pacifico e nada selvagem. Na composição dos quadros, contudo, somos levados a pensar, devido aos indícios fornecidos pelas linguagens verbal e não-verbal, que o lobo é de fato mau. O humor se estabelece a partir da quebra de expectativa, quando descobrimos que não se trata de um porco, mas de um cofre de onde o lobo tira algumas moedas para comprar lingüiça e lombo, ou seja, ao invés de caçar ele vai comprar (Fig. 56). 

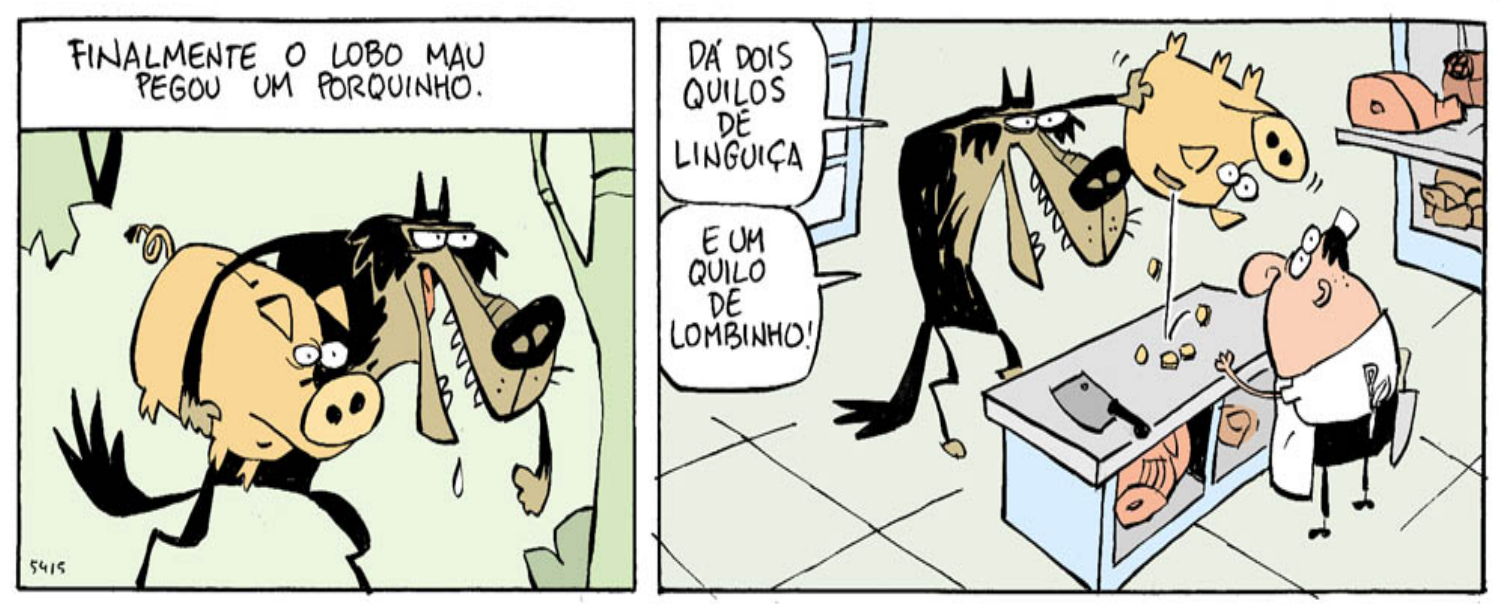

Fig. 56 - A figura do lobo com uma gota caindo de sua boca no primeiro quadro reforça a impressão de que ele está faminto (e que vai comer o porquinho). No quadro final, seu comportamento contradiz os elementos indiciais apresentados no quadro anterior.

Em outro momento, numa referência à estória da Chapeuzinho Vermelho, nos deparamos com uma versão mais sexual do conto. A fala da vovó, sua figura de formas sinuosas e o contraponto da ilustração de outra vovó envelhecida olhando por uma janela, ampliam o contraste tematizado na tira: de um lado a vovó como uma figura idosa e de outro, a vovó jovem e cobiçada pelos “lobos” (Fig. 57). Nesse caso, o humor se dá não necessariamente pela quebra de expectativas, como nas tiras anteriores, mas pelo aspecto o subliminar expresso pelas linguagens verbal e não-verbal e que revelam o caráter sexual da estória. 


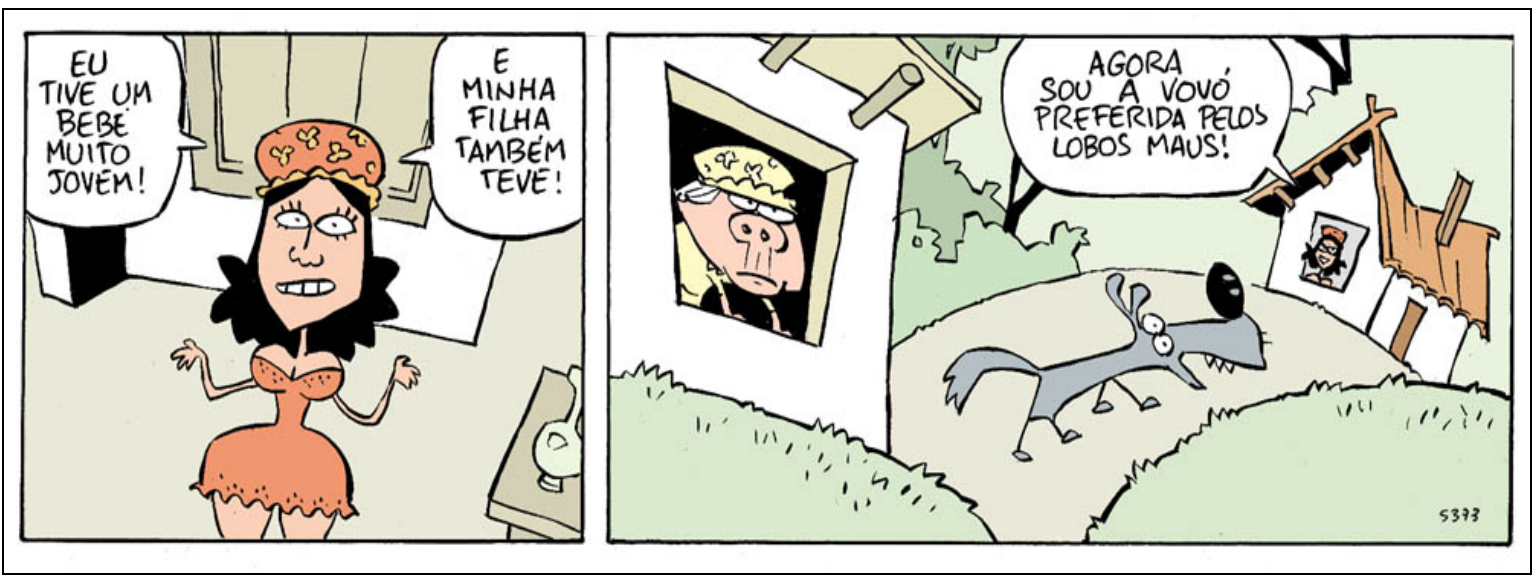

Fig. 57 - O vestido curto e decotado da vovó reforçam a idéia de juventude que vem expresso pela linguagem verbal

Ainda no universo da Chapeuzinho Vermelho e também dos três porquinhos, temos outra situação que dialoga com as estórias tradicionais. O humor se revela ao percebermos o esforço fracassado de chapeuzinho em não magoar os porquinhos. A fala da vovó contrariando a menina e a resposta que chapeuzinho dá no último quadro reforçam o efeito cômico da situação (Fig. 58). 

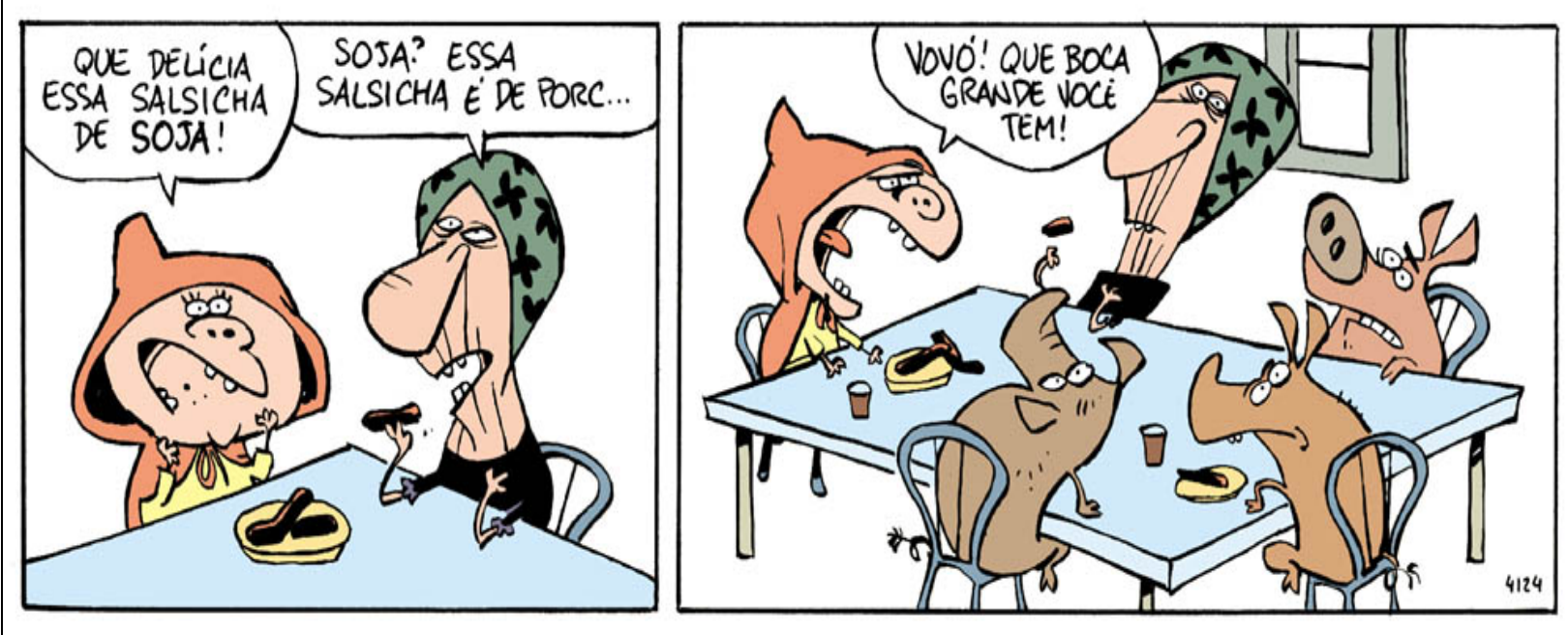

Fig. 58 - O efeito humorístico ocorre não só pelo fato em si, os porquinhos comendo salsichas feitas j de porco e a tentativa de Chapeuzinho de disfarçar a situação, mas também pela fala da menina no último quadro, que remete ao famoso bordão proferido por ela quando encontra o lobo: “que boca grande você tem”.

Nas tiras de Gonsales temos, por meio do uso de elementos tradicionais do humor, como a quebra de expectativas, apresentação das personagens em outra chave, etc., o diálogo com estórias tradicionais, trazendo o lúdico e novas propostas de construção para as mesmas. Temos aqui um diálogo bem humorado com as estórias, em que novas proposições e desfechos são introduzidos nas versões, rompendo com as formas préestabelecidas de apresentação dessas narrativas. A possibilidade do uso pedagógico também pode ser identificada em tais produções na medida em que dialoga com os clássicos propondo novas formas de assimilação e construção dos mesmos, abrindo espaço para diferentes interpretações e interações do leitor.

Quando pensamos na produção de língua portuguesa, o humor tem sido uma das principais ferramentas para o diálogo entre quadrinhos e o material literário no que diz respeito à criação de novas e diferentes obras. Nos dois exemplos anteriores tal fato fica 
patente, entretanto, não é apenas pelo humor que tal forma de diálogo pode ocorrer. Para exemplificar outra possibilidade interativa, apresentaremos uma obra produzida originalmente em Língua Inglesa, mas que traduz de maneira fluente, uma interação que vai além do enredo original, estabelecendo diálogo com o próprio autor da obra-base (Shakespeare).

\section{b) Shakespeare no mundo dos sonhos}

Em Sandman Terra dos Sonhos - Sonho de Uma Noite de Verão, Neil Gaiman (roteirista) e Charles Vess (arte), estabelecem uma relação entre obras que põe em cena não apenas os textos elaborados, mas o próprio autor da obra clássica com o qual o quadrinho dialoga, ou seja Shakespeare, numa intersecção de textos, personagens e mitologias. Confrontar personagens (e o próprio autor, no caso) literários com figuras de quadrinhos revela um outro tipo de diálogo que diz respeito aos próprios cânones. No diálogo em destaque temos de um lado Shakespeare e seus Sonhos de Uma Noite de Verão, obra e autor considerados clássicos da literatura mundial, de outro Sandman, personagem que se consagrou nos quadrinhos, tornando-se ícone do meio. No diálogo entre ambos, colocam-se no mesmo "palco" figuras de peso que se consolidaram em seus respectivos meios e a relação entre eles se realiza com maior fluência, na medida em que traz elementos reconhecidos pelos leitores de ambas as obras. 
No Brasil, um dos primeiros a fazer esse tipo de inter-relação foi Monteiro Lobato, que colocava seus célebres personagens para interagir com grandes nomes da literatura, história, etc. Nos quadrinhos, temos a Turma da Mônica de Maurício de Souza, que também estabelece constante diálogo com várias esferas da cultura. Contudo, em ambos os casos o humor ainda é a tônica principal. De qualquer forma, o que se depreende de tal fato é que, tanto no caso de Sandman, como o Sitio do Pica-pau Amarelo ou A turma da Mônica, o que temos são personagens consagradas, que já conquistaram um espaço em sua devida área. São ícones e considerados como clássicas por muitos. Daí que a interação entre elas se dá de maneira mais marcante, sobretudo para aqueles que já conhecem e se relacionam com as mesmas. Vale lembrar que no Brasil as HQs, alem de sofrerem com a forte concorrência estrangeira, que já tem consolidada e amplamente divulgada sua tradição, não contam com um verdadeiro apoio para sua produção, daí a dificuldade de consolidar a existência de personagens e outros elementos na tradição dos quadrinhos.

Sandman, considerada a maior obra de Gaiman para as HQs, estabelece um constante diálogo com clássicos da literatura e do cinema, trechos de músicas, e muito mais. Na realidade, Sandman não é uma criação de Neil Gaiman. A personagem surgiu nas HQs na década de 30 (a Era de Ouro dos quadrinhos) e era um detetive chamado Wesley Dodds, que usava uma arma de gás para colocar os bandidos para dormir. Outras versões de Sandman se seguiram, mantendo apenas o nome em comum. Quando Gaiman relançou o título, apenas aproveitou o nome e recriou totalmente a personagem, contando a história de Sandman ou Lorde Morfeu (Sonho), regente do Reino do Sonhar e um dos sete Perpétuos, 
que na verdade caracterizam antropomorficamente aspectos integrantes da condição humana: Morte, Delírio, Destruição, Desejo, Desespero, Destino.

O literato e dramaturgo William Shakespeare aparece em 3 edições de Sandman: Casa de Bonecas - Homens de Boa Fortuna , \# 14 ; Terra dos Sonhos - Sonho de uma Noite de Verão" , \# 19 e "O Despertar - A Tempestade" , \# 75. Em Homens de Boa Fortuna, Shakespeare, até então um jovem dramaturgo medíocre, faz um estranho acordo com Sandman (o senhor da Terra dos Sonhos): sonhos em troca de peças teatrais. É a partir desse acordo que Shakespeare se torna um grande escritor, ou seja pela intervenção de Sandman em seus sonhos. Lorde Morfeu, por sua vez, como devia um favor ao senhor de Faerie, do reino das fadas, faz Shakespeare escrever Sonhos de uma Noite de Verão. O trato também envolvia a encomenda de outra estória (A Tempestade), que é apresentada na edição 75 (Fig. 59). 


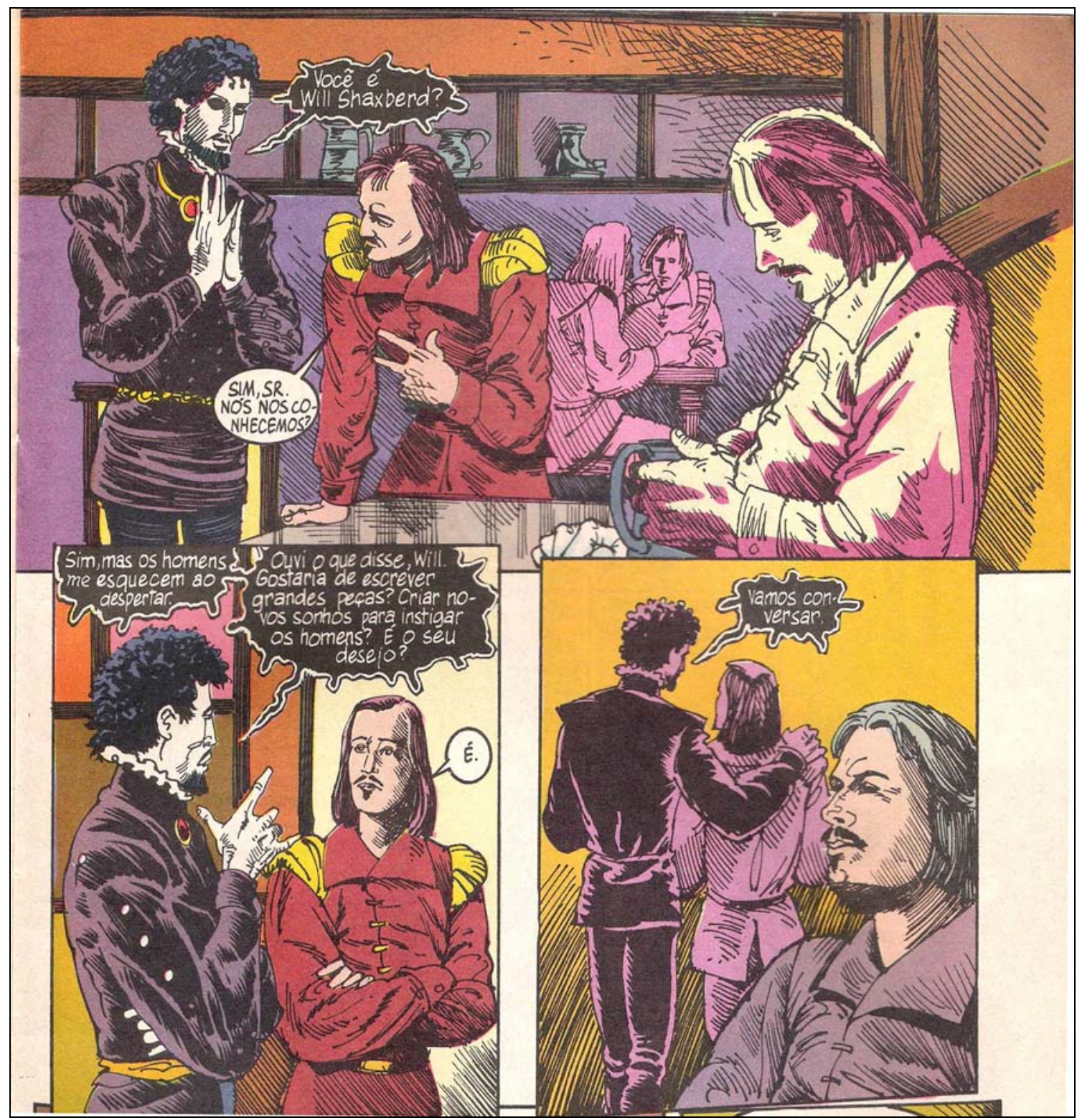

Fig. 59 - Sandman (identificado pelo balão de fala com contorno irregular e na cor preta) ao ouvir o desejo do dramaturgo, se aproxima para fazer o acordo. O homem que surge em primeiro plano no primeiro e último quadros é na verdade Goethe, com quem Shakespeare conversava antes do Lorde Morfeus chegar.

As duas peças escolhidas por Gaiman para estabelecer o diálogo com Shakespeare, Sonho de uma noite de verão e A tempestade, apresentam, em comum, o fato de serem ricas em “espetáculo visual” (BLOOM, 1998, p.199), aspecto essencial para os quadrinhos. 
A peça de Shakespeare, por abordar o tema do sonho, permite um laço ainda mais estreito com a obra em quadrinhos Sandman, cuja personagem principal é justamente o Senhor dos Sonhos. Em Terra dos sonhos - Sonho de uma noite de verão, Lorde Morfeu e as personagens do reino das fadas (Titânia, Oberon, Puck e outros) se encontram com Shakespeare e sua companhia teatral para assistir a peça que o dramaturgo criara de encomenda para o senhor do reino dos sonhos, e que fora inspirada na platéia que o viera assistir, a qual Shakespeare tivera a oportunidade de conhecer por intermédio de Sandman, durante seus sonhos, fato que, contudo, fica subentendido no enredo.

Logo nas primeiras páginas da HQ, temos o reencontro de Shakespeare com Lorde Morfeu. Na retratação de Sandman, vemos os aspectos que geralmente o identificam nos quadrinhos: os olhos negros e estrelados como a noite, a cor pálida e principalmente o balão de fala, que sempre é representado com fundo preto ${ }^{23}$ (Fig. 60).

\footnotetext{
${ }^{23}$ A figura de Sandman, apesar de geralmente apresentar tais características, já foi retratado de maneiras diferentes, assumindo até mesmo a aparência de animais, como um gato na estória Sonho de Mil Gatos ou uma raposa, no livro Caçadores de Sonhos.
} 


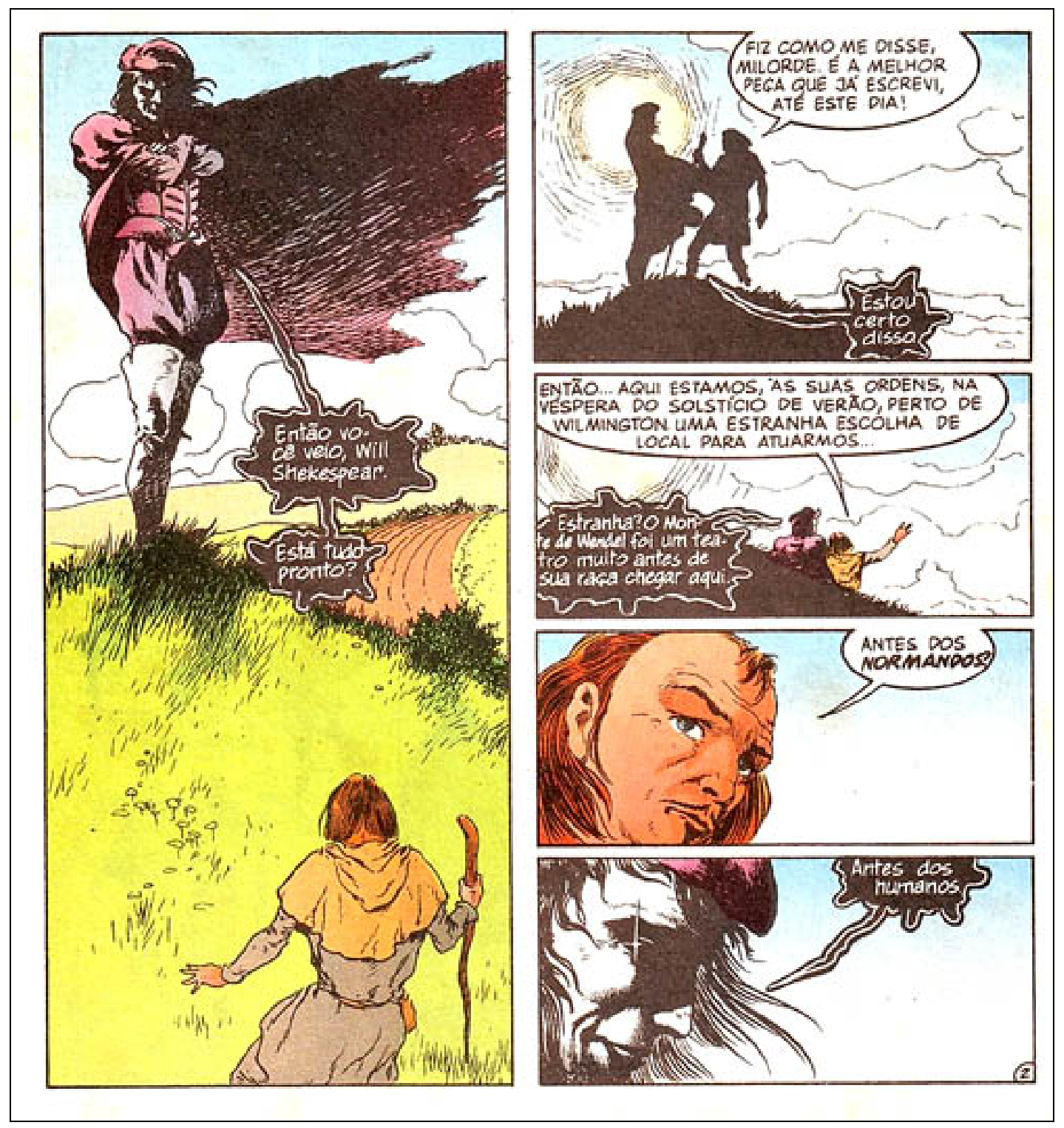

Fig. 60 - No primeiro quadro da seqüência, Sandman surge numa tomada de baixo para cima, o que engrandece sua figura, conferindo-lhe poder diante da imagem de Shakespeare que aparece na parte de baixo do quadro. Os closes nos rostos das personagens nas duas últimas vinhetas, num jogo de ponto e contra-ponto em que a 'câmera' pula de um interlocutor para o outro, recurso muito utilizado no cinema, da dinamicidade ao diálogo de ambos.

Enquanto na obra de Shakespeare o tema gira em torno dos encontros e desencontros amorosos entre dois casais e da discórdia entre a rainha das fadas Titânia e o rei dos duendes Oberon, causada pela tutela de um menino, na obra em quadrinhos o foco recai sobre a interação entre Shakespeare e sua companhia teatral, de um lado, e Sandman e 
os habitantes do reino das fadas de outro. Numa das seqüências, vemos o espanto de Shakespeare diante da platéia para a qual deve representar (Fig. 61), o que mostra o inusitado da situação: o dramaturgo não esperava ver de perto aqueles a quem conhecera apenas nos sonhos.

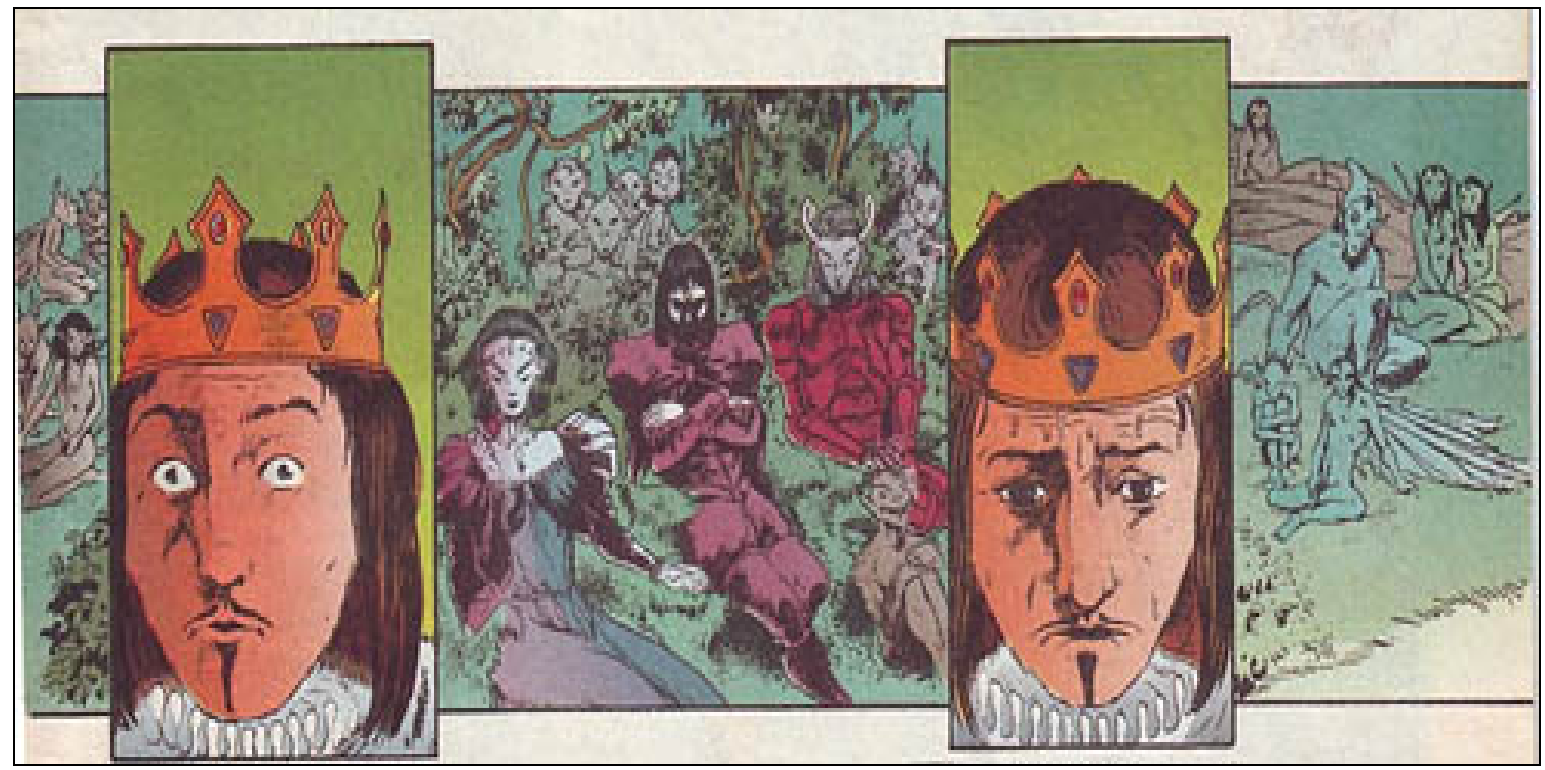

Fig. 61 - As ilustrações do rosto de Shakespeare, sobrepostas às figuras dos habitantes do reino das fadas revela situações simultâneas: a platéia que aguarda o espetáculo e as reações do dramaturgo diante deles: espanto, no primeiro quadro, e medo, num segundo momento.

Assim como na estória original, também há a presença de uma criança, por quem Titânia demonstra interesse. A criança em questão é o próprio filho de Shakespeare, chamado Hamnet, a quem Titânia cerca tentando levá-lo para seu reino, fato que, aliás parece ocorrer, o que fica implicitamente indicado na estória, pois ao final somos informados de que o menino morre três anos após aquela apresentação, com a idade de onze anos. O que reforça tal idéia são os comentários de Hamnet sobre sua relação difícil com o pai: ele se queixa da ausência de Shakespeare e de sua fixação pelo teatro, relegando 
a relação familiar a segundo plano. Uma de suas falas é reveladora: “minha irmã gêmea brincou que, se eu morresse, ele escreveria uma peça sobre mim 'Hamnet”' (seria uma referência à famosa peça de Shakespeare Hamlet?).

Durante a peça, as personagens do reino das fadas questionam e até mesmo negam fatos que são representados pelos atores, como no trecho em que Puck, mesmo empolgado com o momento em que se vê representado na peça, afirma não ter acontecido nada daquilo (Fig. 62). Em outro trecho, é o rei Oberon que, ao conversar com Sandman e Titânia, reafirma a falsidade do que foi representado (Fig. 63). O questionamento da obra clássica inglesa pelos quadrinhos vem expressa pelas próprias personagens, colocando em cheque os fatos narrados no texto-base, e ao mesmo tempo lhe conferindo veracidade, na medida em que, quem questiona são as próprias personagens do reino das fadas, que habitam o mundo da ficção criado por Shakespeare.

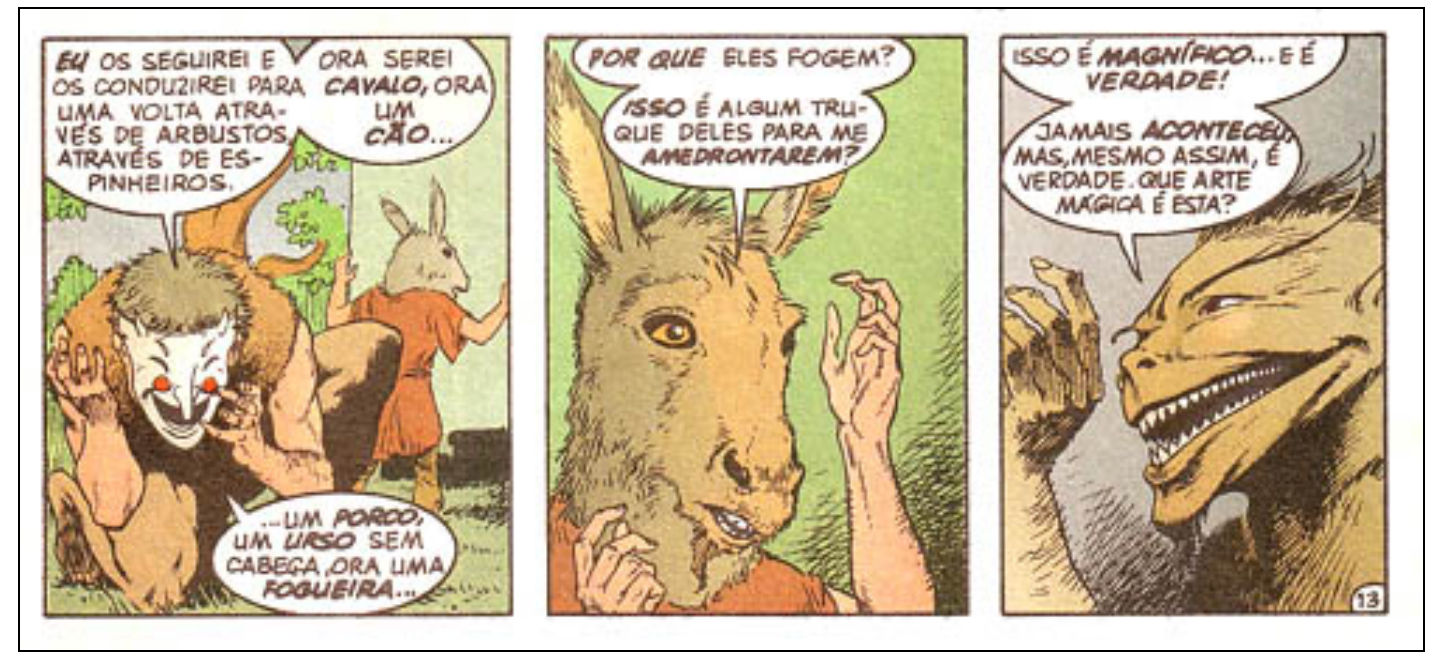

Fig. 62 - No primeiro quadro temos a figura do ator personificado como Puck, e no último o próprio Puck aplaudindo a cena. 


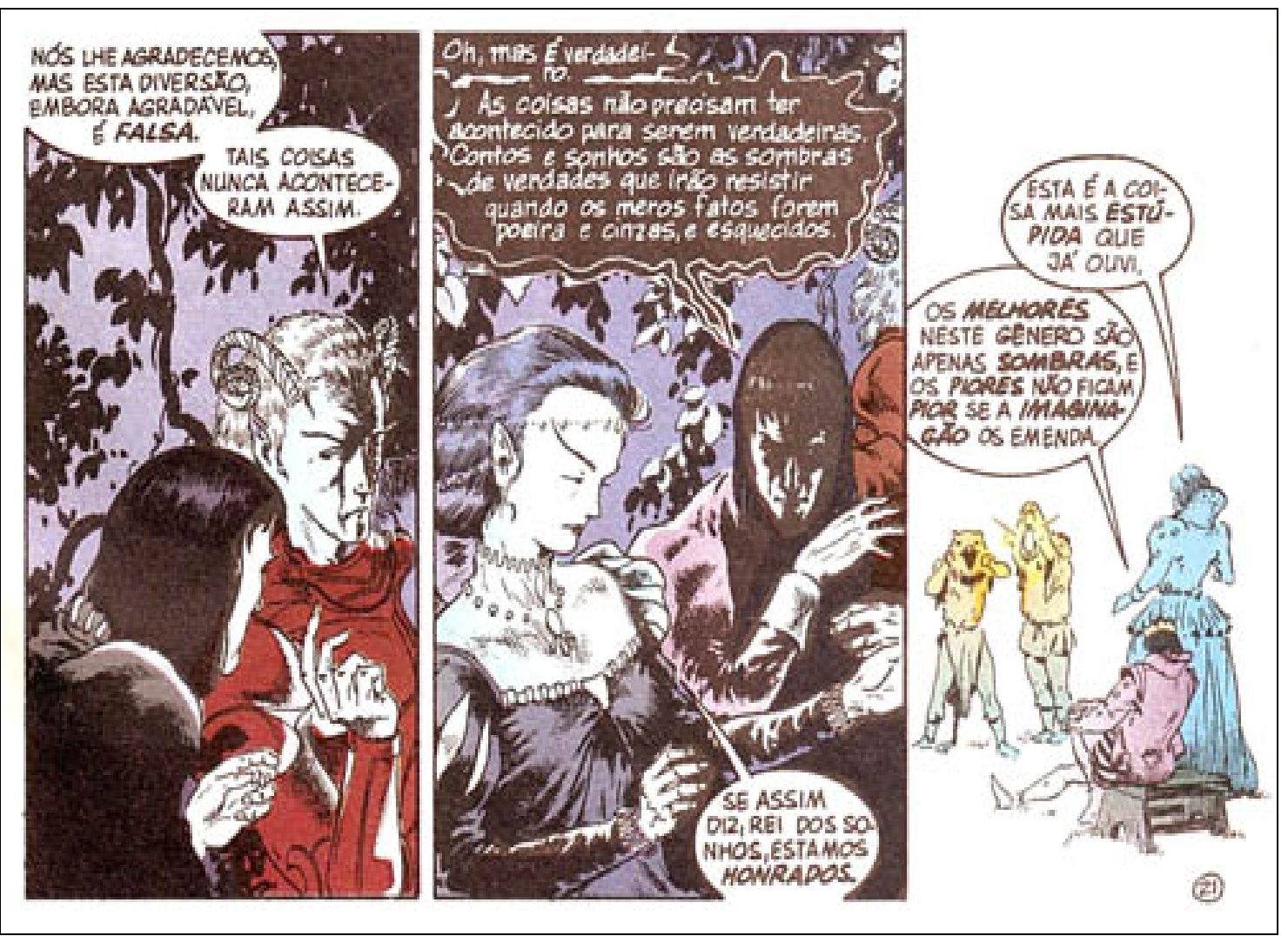

Fig. 63 - Os tons sombrios e escuros acompanham a caracterização da personagem Sandman.

Na obra em quadrinhos, a personagem Puck se mostra essencial para o desenrolar dos fatos. Aliás, é ele que ajuda a ampliar o tom sombrio da HQ. Sua representação, assim como os outros seres do reino das fadas, é disforme, e as cores escuras acompanham suas ações. Sobre Puck, na obra original de Shakespeare, Harold Bloom (1998, p.198) destaca:

Puck [...] é figura ambivalente, um traquinas, um tanto maldoso, embora a peça (e Oberon) o mantenha inofensivo, chegando mesmo a fazer com que o mal por ele praticado resulte no bem. O outro nome de Puck, na peça e no folclore popular, é Bom Robin, mais um moleque do que um espírito do mal [...]. Em língua inglesa, a palavra puck, ou pook, originalmente, significava um demônio, ou um homem perverso; Robin Goodfellow (Bom Robin) era o nome popular do diabo. Contudo, em todo o decorrer da peça [...] Puck permanece sob um controle firme e benigno. 
No quadrinho, contudo, diferente da peça em que ele expressa seu lado benevolente, ainda que sob o controle de Oberon, Puck mostra seu aspecto mais diabólico. Ele enfeitiça o ator que o representa na peça, assumindo ele mesmo o seu lugar e dando um caráter mais sombrio à sua representação. Quando a peça acaba, ele escolhe não voltar para o mundo das fadas, afinal, há “mortais para confundir e importunar” (p.22). Quando pronuncia as falas finais do texto de Shakespeare, Puck dá outro contorno às mesmas. No texto original, temos:

Se vos causamos enfado por sermos sombras, azado plano sugiro: é pensar que estivestes a sonhar; foi tudo mera visão no correr desta sessão. Senhoras e cavalheiros, não vos mostreis zombeteiros; se me quiserdes perdoar, melhor coisa hei de vos dar. Puck eu sou, honesto e bravo; se eu puder fugir do agravo da língua má da serpente, vereis que Puck não mente. Liberto, assim, dos apodos, eu digo boa-noite a todos. Se a mão me derdes, agora, vai Robim, alegre, embora. (SHAKESPEARE, 2002, p.50)

Já nos quadrinhos, tal trecho assume um aspecto misterioso, efeito obtido por meio da complementaridade entre as linguagens verbal e não-verbal, compondo um cenário escuro e aterrorizante (fig. 64). 


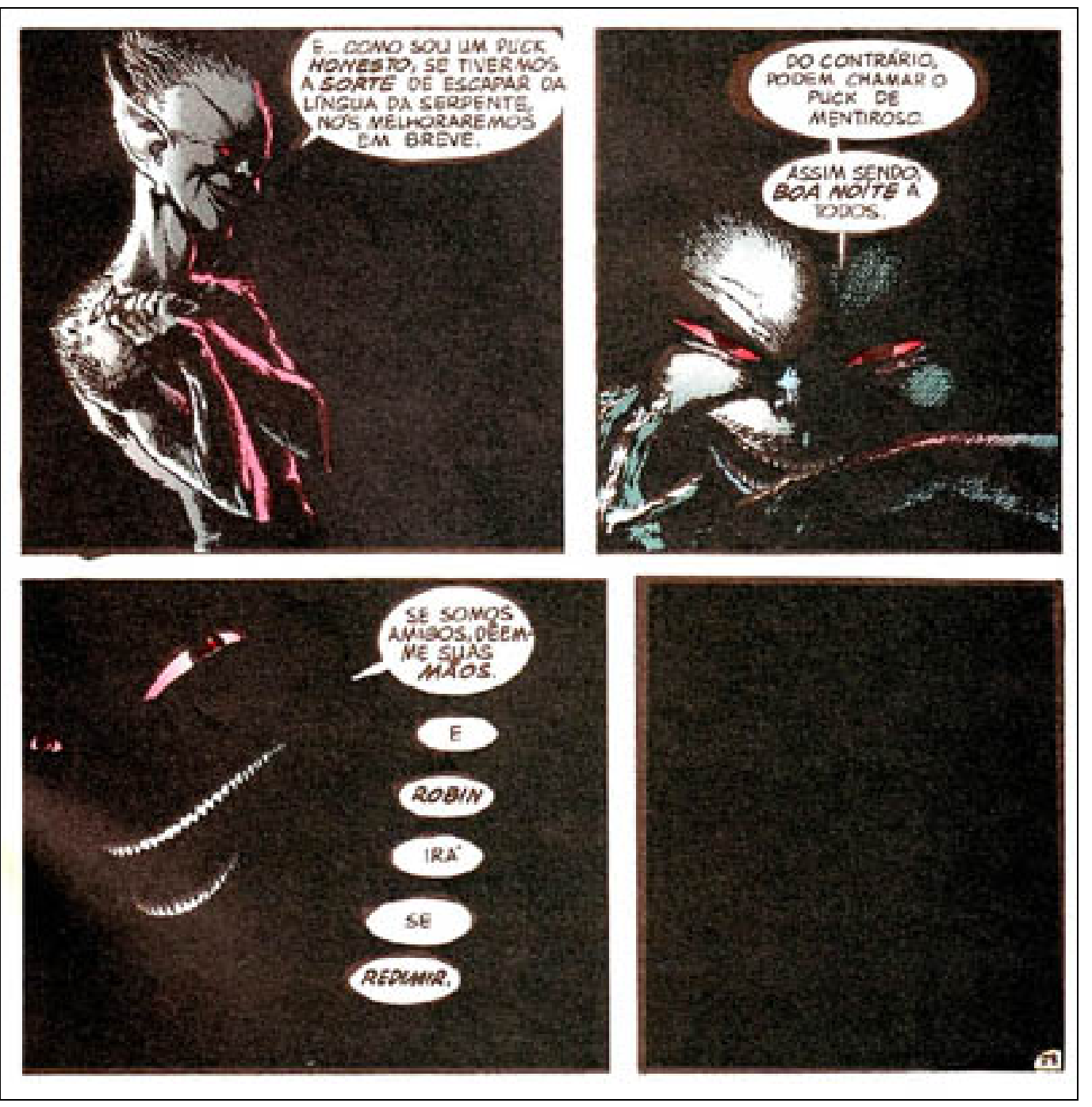

Fig. 64 - Nos quadros acima, na medida em que Puck fala a imagem vai se tornando mais escura e a câmera parece se aproximar ainda mais dele até escondê-lo nas sombras, elemento da qual ele faz parte. A fala entrecortada no penúltimo quadro dá a sensação de uma pronúncia pausada, que acompanha a própria diluição de Puck na escuridão que o envolve.

O lúdico, o questionamento da obra clássica, o aproveitamento de elementos tradicionais em outras chaves (como o terror) constrói uma nova narrativa sobre a original. Não temos apenas a obra de Shakespeare, mas também, e talvez principalmente, a de Sandman, afinal é ele quem inspira o dramaturgo, quem move as forças sobrenaturais, quem cria a ponte entre os mundos. Ao final, é o Puck do universo dos sonhos e não o da 
peça de Shakespeare quem prevalece, sobrevive e contamina o mundo dos mortais com suas sombras e terror. É por meio de elementos enraizados e consagrados no mundo dos quadrinhos e da literatura que tal diálogo se dá, estabelecendo uma relação que, como vimos, vai além das personagens, envolvendo até mesmo seus criadores. 


\subsubsection{Interferências e aproximações}

O diálogo entre o quadrinho e o material literário, como pudemos observar, produz obras diversas com muitas possibilidades interativas. De uma forma geral, poderíamos resumir as formas de transposição de obras literárias para as HQs conforme a seguinte tabela:

\begin{tabular}{|l|l|l|}
\hline Tipos de diálogo & Formas de transposição & $\begin{array}{l}\text { Relação dos recursos } \\
\text { estéticos das HQs com o } \\
\text { texto-base }\end{array}$ \\
\hline $\begin{array}{l}\text { Adaptações pastiche } \\
\text { (A Moreninha, Gaetaninho) }\end{array}$ & $\begin{array}{l}\text { Fiel à obra-fonte, } \\
\text { procurando reproduzi-la de } \\
\text { maneira mais próxima } \\
\text { possível }\end{array}$ & $\begin{array}{l}\text { Estética dos quadrinhos a } \\
\text { serviço do texto-base }\end{array}$ \\
\hline $\begin{array}{l}\text { Adaptações criativas } \\
\text { (Lusíadas 2500, Branca de } \\
\text { Neve) }\end{array}$ & $\begin{array}{l}\text { Inserção de diferentes } \\
\text { elementos na narrativa }\end{array}$ & $\begin{array}{l}\text { Possibilidade de utilização } \\
\text { diferenciada dos recursos } \\
\text { das HQs, sem perder o fio } \\
\text { condutor (o enredo } \\
\text { literário) }\end{array}$ \\
\hline $\begin{array}{l}\text { Novas dimensões narrativas } \\
\text { (Patinho Feio, tiras de } \\
\begin{array}{l}\text { Gonsales, Sandman-Sonhos } \\
\text { de Uma Noite de Verão) }\end{array}\end{array}$ & $\begin{array}{l}\text { Criação de novas obras a } \\
\text { partir de elementos do texto } \\
\text { original. O texto-base ou } \\
\text { seus elementos surgem em } \\
\text { novas chaves (humor, } \\
\text { terror, etc.) }\end{array}$ & $\begin{array}{l}\text { Recursos das HQs não } \\
\text { submetidos ao enredo } \\
\text { original }\end{array}$ \\
\hline
\end{tabular}

O tipo de interação se dá a partir de uma gradação em que as obras produzidas em quadrinhos apresentam cada vez mais interferência no texto-base. Vale ressaltar que, numa mesma categoria também temos uma gradação em que há história em quadrinhos mais próxima do texto literário do que outras. Com pouca interferência na obra-fonte, temos quadrinizações como A Moreninha (1953), que traz uma adaptação pouco dinâmica e mais didatizada e Gaetaninho (2006), que apesar de explorar de maneira mais criativa os 
recursos da visualidade dos quadrinhos, busca uma representação próxima do conto de Machado. Ambas procuram adaptar o mais fielmente possível a obra literária, não só pelo texto verbal, mas também pelo aspecto visual, daí a utilização dos recursos dos quadrinhos de forma a reproduzir o estilo da obra: o uso abundante de balões para representar os diálogos tão comuns nos folhetins em A Moreninha e a dinâmica visual de Gaetaninho para revelar o olhar ligeiro da crônica jornalística de Macedo.

O que prevalece, contudo, tanto em A Moreninha quanto em Gaetaninho é a busca pela reprodução da obra literária com a mínima interferência possível. Ambas as obras, apesar de distantes no tempo, revelam uma visão pedagógica semelhante em relação à quadrinização de obras literárias, na qual prevalece a idéia de que as HQs servem como mediadoras de leitura e seus recursos como reprodutores dos efeitos próprios do texto literário, cuja linguagem verbal é a principal ferramenta. Assim não há a inserção de elementos novos e a estética visual obedece aos ditames da obra original.

Seguindo a gradação no que diz respeito à relação da obra quadrinizada com o material literário, há as HQs que introduzem novos elementos ou formas de contar ao enredo original, provocando uma maior interferência no texto-base. Aqui já ocorre um maior afastamento do texto literário que, contudo, ainda continua a ser o guia para a construção narrativa. Não se trata de modificar a estrutura do texto-base, que pode ser reconhecido pelo leitor, mas sim propor diferentes formas de olhar e interagir com o mesmo. É o caso de Lusíadas 2500, em que os versos de Camões, numa mudança de gênero, se tornam roteiro para uma ficção científica. Por meio da visualidade e de alguns 
recursos estéticos dos quadrinhos um novo contexto é criado e acrescentado à obra original. Ainda não há uma total fluência do uso dos recursos das HQs, pelo fato de termos duas dimensões narrativas: a do livro ilustrado e a dos quadrinhos propriamente dito, mas ainda assim, os recursos cênicos inseridos na épica portuguesa propõem um novo olhar sobre a mesma. Também é o que se dá com a adaptação de Branca de Neve, que sugere uma interação que se aproxima mais de um jogo de montar do que de uma narrativa dinâmica. A inserção de tais elementos/formas de contar propõe outras formas de se relacionar com a obra original, um diferente "olhar" sobre a mesma.

Outro tipo de diálogo é o que sugere a criação de obras que se aproveitam do material literário (enredo, personagens, cenários, etc.) para construir narrativas que questionam e inovam as tradicionais, apresentando-as em novos contextos, revelando um distanciamento com a obra-base maior do que todas as outras formas já apresentadas. Nos exemplos destacados nesse estudo, temos desde a paródia de fábulas, a desconstrução de contos tradicionais até a proposição de diferentes maneiras de realização de enredos clássicos. Em O Patinho Feito (ou Patus Horribilis), a paródia é o elemento chave para questionar o conto tradicional e explorar uma maneira diferente de condução do enredo. Também é por via do humor que nas tiras de Níquel Náusea as personagens de fábulas e de contos de fadas vêem desconstruídos elementos originais de sua estória. Em Sandman Sonhos de Uma Noite de Verão, por seu lado, a proposição de um novo enredo unido aos elementos da obra-base, e até mesmo de seu autor, criam uma estória diferente, com ingredientes de terror, que inova a tradicional. Na atualidade, essa forma de diálogo com elementos tradicionais da literatura é bastante comum, e temos personagens de contos de 
fadas ajudando a vender perfumes e condomínios, enredos tradicionais como pano de fundo de mirabolantes tramas em novelas ou filmes, músicas que citam importantes figuras literárias e muito mais. 


\section{3- Outras formas de interação}

Visando oferecer uma visão mais ampla sobre a relação quadrinhos-literatura e as possibilidades que ela oferece para a veiculação das experiências humanas, destacaremos também duas outras formas de diálogo possível entre ambos os meios. A primeira diz respeito à adaptação/interação de obras dos quadrinhos para a literatura, num movimento contrário ao visto até agora. O segundo propõe a criação de obras em que as duas artes se unem para o desenvolvimento da narrativa. Apesar desse não ser o foco de nossa pesquisa, traz importantes elementos que nos permitem conhecer melhor os processos de criação dialógica que se estabelecem quando obras produzidas em artes distintas se interseccionam.

\subsubsection{Das HQs para os livros}

Também a literatura estabelece diálogos com os quadrinhos tomando de empréstimo enredos, personagens e outros elementos. Geralmente o que temos é o aproveitamento de personagens criados nos quadrinhos para a construção narrativa literária. Em diversos suportes comunicativos é possível verificar o diálogo com os quadrinhos e o universo desenvolvido nele, como as constantes adaptações de HQs para os cinemas, desenhos animados, vídeo games, etc. As aventuras de Batman, por exemplo, ganharam as telas do cinema com várias versões. O mesmo ocorre com outras personagens famosas, como o Super-Homem, o Quarteto Fantástico, os X-men, etc. Nos Fan Fics, textos que circulam 
pela internet e que são escritos por fãs, os clássicos heróis dos quadrinhos ganham novas e eletrizantes aventuras.

No que diz respeito à literatura, o diálogo com os quadrinhos e/ou o aproveitamento de elementos criados nas HQs para desenvolver textos literários, contudo, não é muito praticado, sobretudo em Língua Portuguesa. No exterior, temos mais exemplos, como os livros de estórias baseadas nas aventuras de Batman, Sandman, e outros.

Assim como na relação literatura-quadrinhos, as possibilidades interativas entre os meios de expressão podem variar numa gradação, indo desde uma adaptação fiel à obra original, até aquelas que aproveitam elementos dos quadrinhos para a criação de novas narrativas. Em língua portuguesa, o diálogo mais comum é aquele que propõe a criação de novas obras a partir do material literário, e é feita principalmente por meio do humor, com a satirização de personagens e elementos dos quadrinhos. Dessa vez, as tradições criadas nos quadrinhos é que são questionadas e/ou inovadas a partir do material literário. como no exemplo destacado a seguir.

\section{a) A desconstrução e a renovação do herói}

No conto de Moacir Scliar intitulado Shazam, a famosa personagem dos quadrinhos, Capitão Marvel, é apresentada como um super-herói aposentado, pois o crime no mundo tinha sido extinto, e que resolve viver em Porto Alegre. Com muito humor o autor conta a 
estória fazendo uso, para tanto, de toda a mitologia construída nos quadrinhos sobre os super heróis (força, super poderes, etc.).

A personagem Capitão Marvel, ou Shazam como também é conhecida, surgiu nos quadrinhos em 1940, sendo criado pelo escritor Bill Parker e pelo artista C. C. Beck. A estória começa quando o jovem Billy Batson é escolhido pelo mago Shazam para ser um herói e defender a bondade. Toda vez que Billy pronuncia o nome do mago, um raio mágico o atinge e ele se transforma em um super-herói adulto. Outras pessoas, como amigos ou familiares de Billy também podem se tornar Marvels, compartilhando os poderes com ele (Fig. 65).

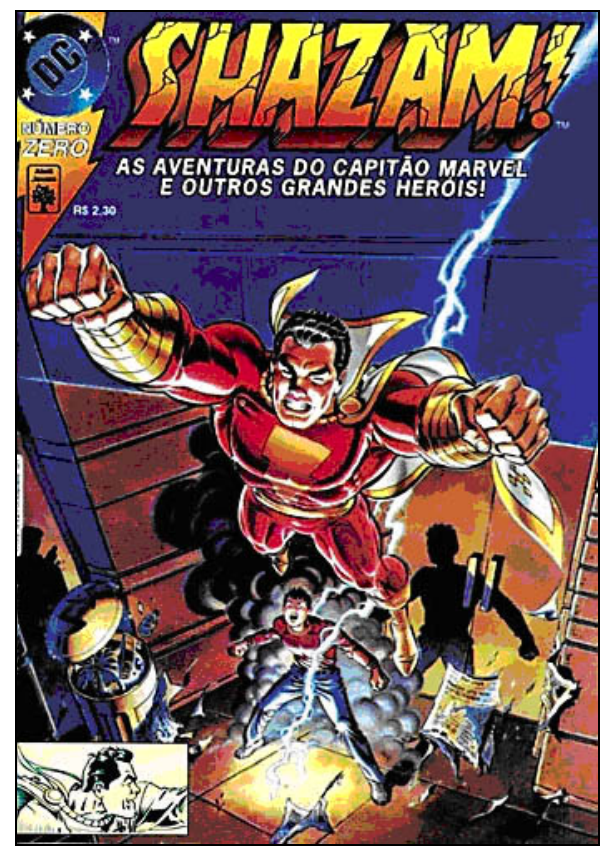

Fig. 65 - O Capitão Marvel, ou Shazam, aparecia em um vistoso uniforme ornamentado por um raio, sua marca registrada. 
Na verdade, o Capitão Marvel surgiu logo após o Super Homem, criado dois anos antes, numa época em que vários heróis despontavam na onda do sucesso obtido pelo homem de aço. O herói, que aparecia em uma roupa vermelha e um relâmpago desenhado no peito, recebia seus poderes de seis importantes personagens mitológicas, cujas iniciais formam a palavra mágica Shazam: Salomão, de quem recebe a sabedoria, Hércules, que lhe fornece a força, Atlas, que lhe dá o vigor físico, Zeus, de quem herda o poder, Aquiles, a coragem e Mercúrio, a velocidade (fig. 66). As aventuras do Capitão Marvel, devido ao seu grande sucesso, geraram além de várias revistas, séries de cinema, desenhos animados, etc.

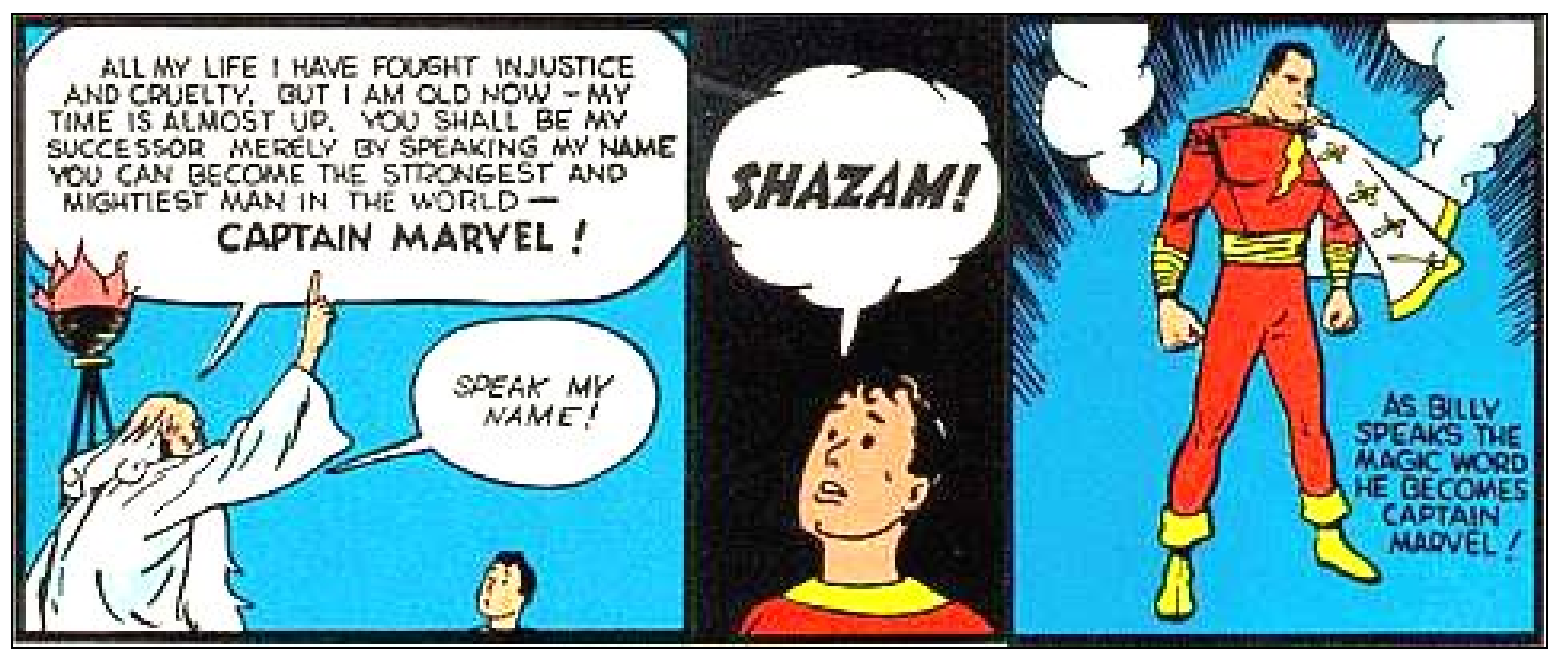

Fig. 66 - Na figura (Cena de Whiz Comics 1 -1940) podemos ver o primeiro encontro de Billy com o mago Shazam.

No conto de Scliar, já no início, vemos a referência satírica feita em relação aos heróis dos quadrinhos, que sofrem devido a seus super poderes (pág.297): 
O Homem Invisível sofria de um forte sentimento de despersonalização. "Preciso apalpar-me constantemente para estar seguro de que me encontro presente no mundo, aqui e agora”, escreveu em seu diário. O Homem de Borracha comprava uma roupa num dia e no outro constatava que já não servia. Tinha encolhido ou alargado - não a roupa, ele. O Príncipe Submarino sofria com a poluição do mar. (...) O Tocha Humana era perseguido por sádicos com extintores (...) O Sombra, que sabia do mal que se esconde nos corações humanos, era incomodado por hipocondríacos com mania de doenças cardíacas. O Zorro recebia propostas indecorosas de um fetichista fixado em objetos começando pela letra Z.

A estória do Capitão Marvel é construída justamente nessa tônica: as agruras e dificuldades do herói diante do mundo real. Mundo que, aliás, como descreve o conto, não sofre mais com crimes, daí a aposentadoria do Capitão Marvel e sua escolha de passar o retiro “eterno” na cidade de Porto Alegre.

A sátira é, como vimos, uma ridicularização de determinado tema/personagem e é isso que o autor faz ao desconstruir o mundo dos heróis, tornando seus poderes obsoletos ou inúteis diante da realidade, retratando a própria realidade de forma irônica (como por exemplo, um lugar em que não há crimes, fato que está longe de acontecer). O Capitão Marvel em sua busca por se ambientar à nova vida - uma aposentadoria forçada, por não ser mais útil diante do novo mundo, com seus heróis de TV e cinema, sem super poderes, mas transbordando violência -, representa a decadência e a falência não apenas do herói, mas de toda uma tradição, e aí se inclui os super-heróis com poderes mirabolantes, um dos principais cânones criados pelos quadrinhos, que se mostra incapaz de confrontar o mundo atual.

Numa referencia a um dos hábitos da sociedade moderna, transformar em produto de consumo qualquer assunto que possa ser vendável, o Capitão Marvel lança um livro de 
memórias que obtém sucesso passageiro, suscitando até mesmo um comentário elogioso da crítica especializada: "Um novo olhar sobre o mundo” (pág.298). Após tal fato o herói cai no ostracismo e se vê diante de uma rotina banal: lendo quadrinhos e plantando flores, e amargando uma depressão.

A sátira aos super poderes dos heróis (e do Capitão Marvel) é feita por meio da confrontação desses poderes com questões práticas da vida. Em um determinado sábado, Capitão Marvel vai ao bar e lá conhece uma mulher, após tomar 11 cálices de bebida. Aqui temos uma referência ao aspecto pouco sexual dos super heróis, tão envolvidos em sua tarefa de salvar o mundo. O Capitão Marvel, contudo, passa a considerar a possibilidade de uma aproximação:

O Capitão Marvel considerou-a em silêncio. Nunca dera muita atenção a mulheres; o combate ao crime sempre fora uma tarefa demasiado absorvente. Mas agora, aposentado, o Capitão Marvel podia pensar um pouco em si mesmo. $\mathrm{O}$ espelho descascado mostrava que ele ainda era uma esplendida figura de macho, o que ele reconheceu com alguma satisfação. (pág.299)

A descrição da mulher, por sua vez, ressoa a decadência da própria vida do herói aposentado:

"Quanto à mulher, não era bonita. Quarentona, baixa e gorda, estalava a língua depois de cada gole. Mas era a única mulher do bar, naquela noite de sábado. Além disso, não só retribuiu ao olhar do Capitão, como levantou-se e veio sentar perto dele.” (pág.299)

É importante observar como a linguagem verbal é extremamente imagética e ajuda a expressar aquilo que nos quadrinhos é puramente visual. Por meio de uma linguagem irônica, o autor monta um cenário que, contudo, não é revelado em todos os seus detalhes. 
É justamente pela nossa interação com o texto, o preenchimento daquilo que está subentendido no mesmo, que construímos os nexos.

Na seqüência, o Capitão Marvel segue para o quarto com a mulher. Aqui, os aspectos que fazem a glória do herói se revelam como obstáculos para a noite de sexo: a couraça de aço que protege seu corpo se mostra fria e dura demais, o que acaba por ferir sua amante (pág.300):

Um urro de dor fez estremecer o quarto.

- Tu me mataste! Me mataste! Ai que dor!

Assustado o Capitão Marvel acendeu a luz. A cama estava cheia de sangue.

- Me enterraste um ferro, bandido! Perverso!

Mais uma vez, os elementos são indiciados pela linguagem verbal, mas não totalmente explicitados. Por meio da interação com o conto e mais o conhecimento prévio que temos sobre o herói e seus poderes, compreendemos a cena. Sobre os super poderes do Capitão Marvel nos quadrinhos, aliás, é importante ressaltar que ele, por receber o poder de figuras mitológicas, apresentava capacidade de voar, sabedoria, super força, invulnerabilidade do corpo, resistência a venenos, possibilidade de mudar a aparência, coragem, velocidade e longevidade, além de receber a energia do relâmpago que transmutava sua aparência de Billy Batson para Capitão Marvel. No conto de Scliar, por sua vez, temos a pele de aço, que reveste o corpo do herói e que, apesar de invulnerável, já se encontrava “enferrujada nas axilas”, em outra referência irônica (pág.299).

Após tal tragédia, Capitão Marvel, sem saber o que fazer, voa sem destino pela cidade, soluçando e se lembrando saudoso de quando apenas trabalhava em uma rádio. O 
final trágico intensifica a desconstrução do super-herói feita a partir da satirização dos elementos que compõem seu universo: a aposentadoria insossa e decadente após uma vida de combate ao crime, a concorrência dos novos e violentos heróis (que não tem a grandeza do passado), o esquecimento dos fãs, a incapacidade de se relacionar com uma mulher. Enquanto sobrevoa a cidade Capitão Marvel lembra-se que havia uma palavra capaz de o transformar novamente em Billy, mas ele já a esquecera. A palavra é Shazam, o nome do mago que lhe concedera o poder e que ele, naquele momento da vida, não conseguia mais se lembrar (Fig. 67 e 68).
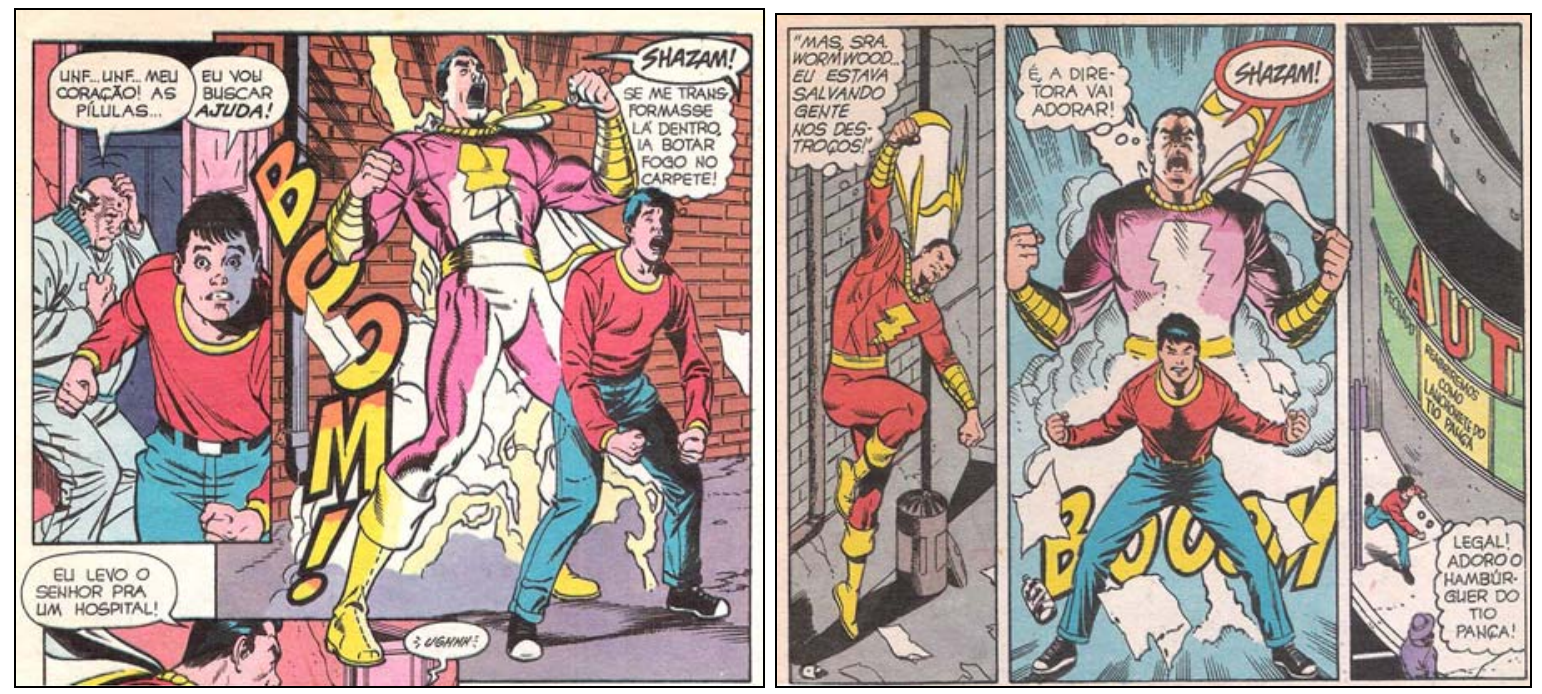

Fig. 67 e 68 - Nas ilustrações retiradas da HQ Shazam, podemos ver como o herói se transformava sob a ação da palavra shazam. Na primeira seqüência, o menino se transforma em herói, e na segunda, o contrário ocorre e Billy, após voltar a ser menino, precisa correr para a escola se não chegará atrasado. Nos dois momentos, a figura de Billy menino e transformado em Shazam na mesma cena, revelam o passo a passo da transformação, efeito ampliado pelo uso da onomatopéia nas cenas.

O diálogo entre o conto de Scliar e a personagem dos quadrinhos Shazam revela como elementos oriundos das HQs podem fornecer material para a construção de narrativas literárias. Shazam, por seu lado, faz parte do universo consagrado das HQs, de seus cânones, daí a possibilidade interativa ser mais eficiente na medida em que são 
reconhecidos por muitos. Também aqui podemos identificar elementos que propiciam o lúdico e até mesmo um uso mais interativo nas práticas pedagógicas, na medida em que fornece material que questiona, inova e traz novas propostas de elaboração. Mas não é apenas por meio desse tipo de diálogo que a literatura se relaciona com os quadrinhos.

Também temos obras que realizam tal diálogo por meio de adaptações pastiche, bem próximas da original. É muito pouco comum tal forma de diálogo, mas temos um exemplo, oriundo da produção literária de Língua Inglesa, que pode nos ajudar a compreender como tal fato ocorre quando da adaptação de histórias em quadrinhos para a literatura.

\section{b) Transpondo linguagens: uma leitura fiel}

Em Os Livros da Magia - o convite de Carla Jablonski, publicada em 2003 originalmente em Língua Inglesa, temos uma adaptação para a literatura da obra quadrinizada homônima, produzida em 4 volumes, e que tem roteiro de Neil Gaiman e ilustrações de vários artistas. Nos quadrinhos, a mini-série criada em 1991 trazia as aventuras de um garoto aparentemente comum, mas que, após ser procurado por um quarteto de homens misteriosos, descobre ter o potencial para se transformar no mago mais poderoso do mundo. O menino, de nome Timothy Hunter, órfão de mãe e vivendo apenas com o pai, usa óculos e tem um iô-iô que se transforma em uma coruja de estimação. Guardadas as semelhanças com a série Harry Potter, a personagem, na verdade, teve suas 
origens na década de 80, sendo criada pela escritora inglesa Diana Wynne Jones. Temos, portanto, uma transição dos livros para os quadrinhos e posteriormente de volta à literatura.

Na série Os mundos de Crestomanci, Diana revela um lugar onde a magia é algo natural, mas que deve ser controlada por um mago poderoso, para que não seja usada incorretamente contra aqueles que não têm poderes mágicos. O personagem Tim Hunter surge no volume A Semana dos Bruxos. Ele é um dos alunos do Internato de Larwood e um dos suspeitos de ser bruxo.

Carla Jabonski em seu livro traz exatamente a estória de Tim que Gaiman e seus parceiros desenvolveram para os quadrinhos. Ali, o menino é procurado por quatro indivíduos que revelam ser ele um bruxo e o convidam para conhecer o que é a magia, numa viagem pelo passado, presente e futuro. A narrativa literária de Carla transfere para o livro as aventuras de Tim, utilizando-se para tanto, de elementos próprios da literatura, ou seja, a linguagem verbal. A adaptação, nesse caso, se mostra extremamente fiel à obra produzida em quadrinhos, com a transformação dos elementos da HQ em matéria literária. Daí o uso abundante de descrições para caracterizar espaço, ambiente, personagens, etc.

Para exemplificar, destacamos a seguir o trecho em que o ioiô de Tim é transformado em coruja. A descrição do livro segue praticamente o roteiro estabelecido pela seqüência de imagens desenhadas por John Bolton (Fig. 69), o ilustrador de Labirinto Invisível, $1^{0}$ volume da série (pág. 40): 
Com um movimento rápido, Dr. Oculto tirou o ioiô da mão dele.

Ei!

Dr. Oculto segurou o ioiô com as mãos em concha. Os olhos de Tim se arregalaram quando uma coruja apareceu com um raio de luz.

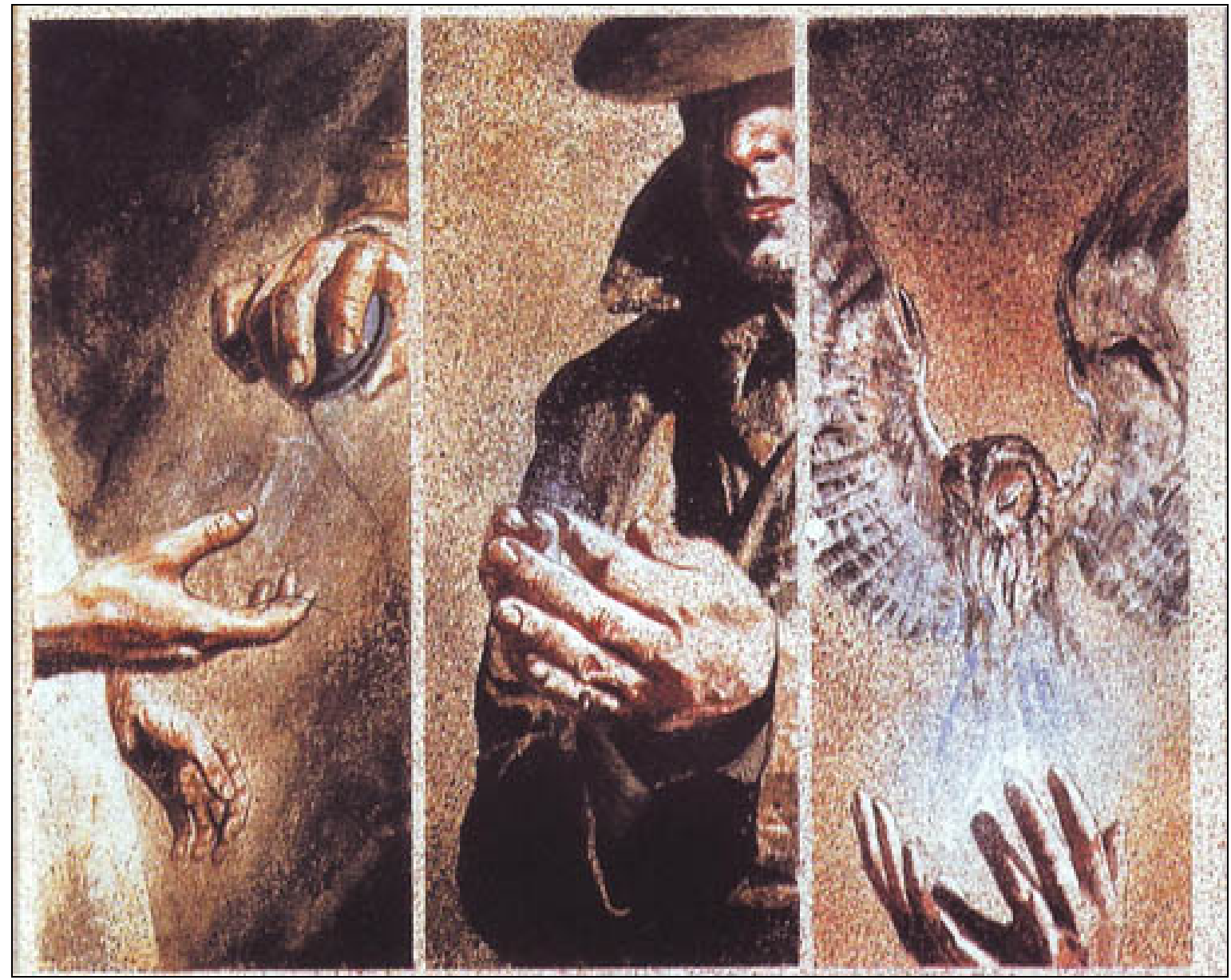

Fig. 69 - Na cena dos quadrinhos, uma seqüência rápida de imagens ilustra a transformação da coruja.

Em outro momento, quando Tim se encaminha com o Dr. Oculto para o reino das

fadas, assim é descrita a passagem das personagens pelo portão que separa os dois mundos

(pág. 157):

Dr. Oculto abriu o portãozinho de madeira. Juntos, ele e Tim o atravessaram. Quando saíram do outro lado, Tim ficou olhando para Dr. Oculto. Ele tinha se transformado em ela!

- Dr. Oculto? - Tim ficou olhando, estupefato, para a mulher a seu lado. Era alta, cabelo liso, castanho e curto. Seu rosto anguloso era bonito, mas comum. Não usava maquiagem e suas roupas eram simples: casaco, blusa, saia. Seria mais 
apropriada para um escritório do que para um reino mágico. - Esta é a sua verdadeira aparência?

Nos quadrinhos, com desenhos de Charles Vess, ilustrador do $3^{\circ}$ volume, A Terra do Crepúsculo do Verão, tal episódio é narrado numa curta seqüência de cenas (Fig. 70):

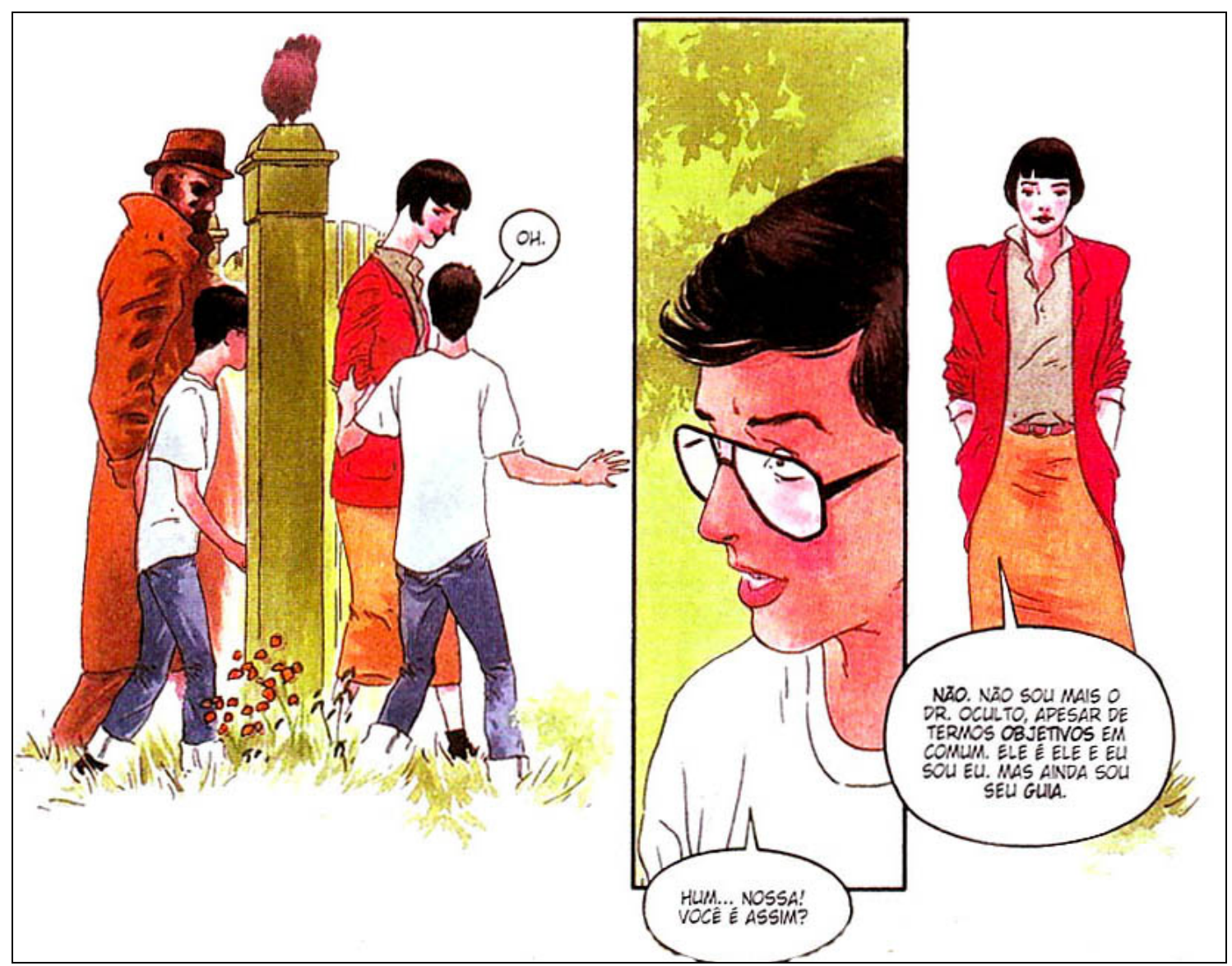

Fig. 70 - Em um mesmo quadro temos a mudança que ocorre quando Dr. Oculto atravessa o portão. A expressão "OH" que sai do balão de fala apontado para Tim, revela o espanto do menino, interpretado no livro como "estupefação”. A descrição detalhada da mulher é ilustrada por Vess em 1 imagem.

O paralelismo entre as obras é constante. Um elemento acrescentado por Carla é a inserção dos sentimentos e pensamentos de Tim e de outras personagens. É a interpretação por via da linguagem verbal daquilo que as ilustrações mostram. Nos quadrinhos, o que temos sobre o mundo interior de Tim são, na maioria das vezes, a forma de representação 
de suas expressões faciais, o jeito como se desloca pelo cenário e seus comentários durante a estória, já que não há a presença de legendas com a voz de um narrador onisciente. Vale ressaltar que o texto verbal de Carla dá mais informações que o de Scliar, dando menos espaço para a interação e a interpretação.

No trecho final, podemos perceber o uso da linguagem verbal como ferramenta literária para expressar os sentimentos de Tim quando, ao voltar de sua viagem pelo mundo da magia, ele encontra dentro de si o poder (pág. 254):

\footnotetext{
Sentiu-se inundado pela raiva. Poderia ter se afogado nela. Como tinham coragem de fazer aquilo com ele? Colocar toda aquela pressão em cima dele! Arrasta-lo por tudo que é canto, do início ao fim dos tempos. Mostrar-lhe mundos com tão pouca explicação. Como eles achavam que ele poderia escolher depois de tudo por que passou?

[...]

- Eu não preciso de vocês. Nem de vocês nem de ninguém. Eu só preciso... acreditar!

A mão de Tim formigou, como se ele tivesse levado um choque. O ioiô assumiu uma nova forma.

Era uma coruja de novo!
}

No livro, tal sentimento é intensificado pelos comentários do narrador onisciente, que nesse momento assume o ponto de vista de Tim. É o menino que se sente abandonado pelos seus quatro tutores. A transformação do ioiô em coruja é descrita em poucas palavras, enquanto nos quadrinhos é utilizada uma seqüência maior de ilustrações, numa transição que lembra uma câmara lenta, revelando o passo a passo da mudança do objeto em coruja (Fig. 71). 


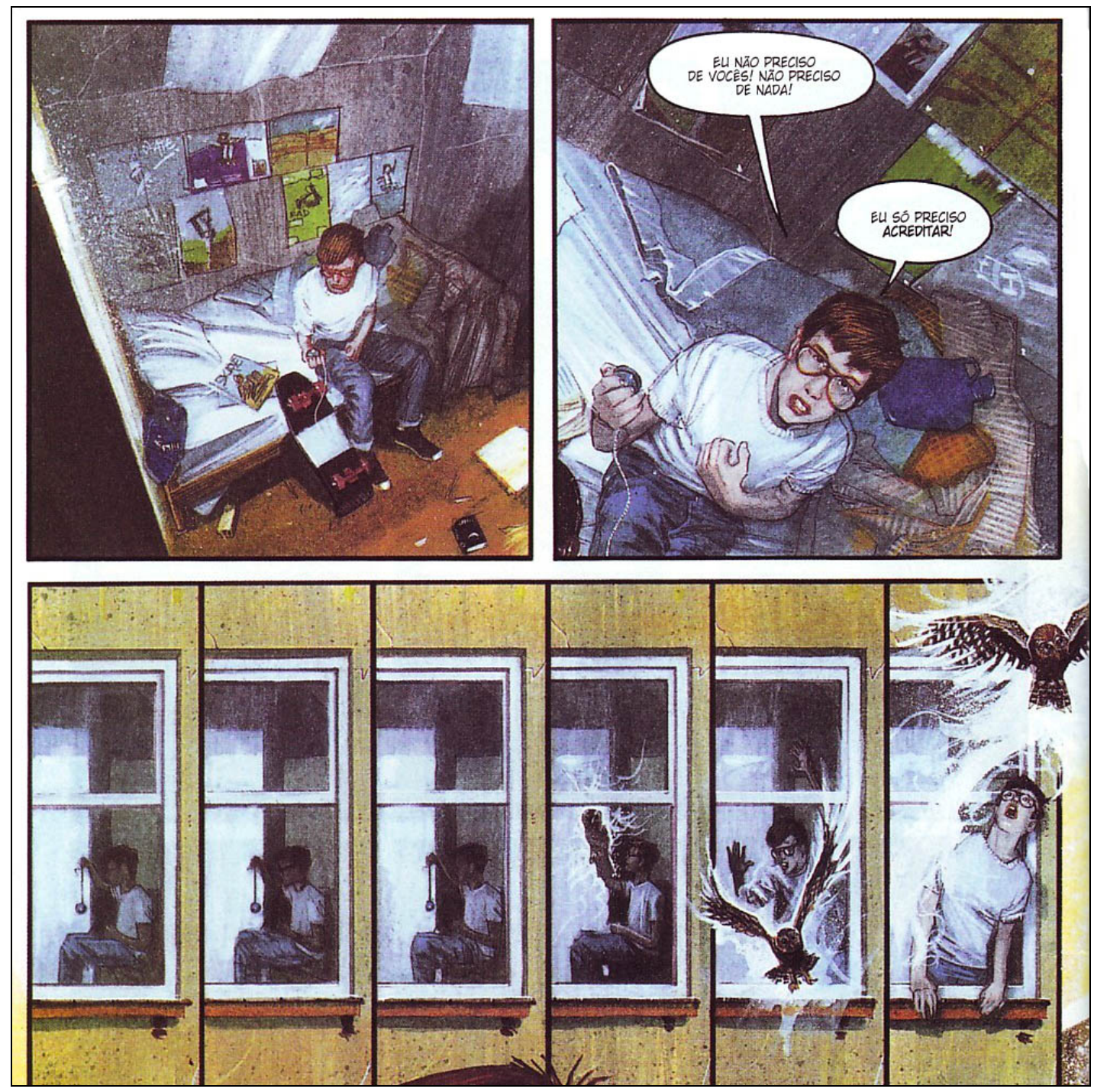

Fig. 71 - Nos quadrinhos, a raiva de Tim se revela por suas expressões faciais e comentários veiculados pelos balões de fala.

A adaptação pastiche dá a tônica da obra de Carla. Os elementos textuais procuram traduzir aquilo que é não-verbal nos quadrinhos. De certo que a transposição quase fiel ao original, assim como visto no caso dos quadrinhos, provoca uma menor inserção do lúdico, na medida em que fecha as vias de interpretação. Ainda assim, a obra oferece outra possibilidade de reflexão e utilização pedagógica, até mesmo por estabelecer um diálogo pouco praticado entre os suportes. Aliás, o que podemos perceber, é que, no diálogo 
inverso entre as HQs e a literatura, a força do texto verbal é também tão imagético quanto o não-verbal, sendo essa uma maneira de se compreender como a linguagem literária pode dar conta de adaptar e expressar o universo construído nos quadrinhos, cuja principal característica é a visualidade.

\subsubsection{Quadrinhos e literatura atuando em conjunto}

Outra forma de interação é aquela em que surgem atuando em conjunto, quadrinhos e literatura, com elementos dos dois suportes Tal forma de relação também não ocorre com muita freqüência, mas há alguns exemplos que revelam como a intersecção das duas formas artísticas pode ser bastante produtiva. Aliás, essa prática é usada por outros meios de comunicação de diversas maneiras.

Nelly Novaes Coelho (2007, p.1), ao resenhar o CD-libreto As Fugas do Sol, do paraibano-paulistano José Nêumanne, assim fala sobre a criação dos gêneros híbridos:

A atual voga dos CDs-libretos de poesia é, sem dúvida, um dos eloqüentes índices de que [...] vem aprofundando a ruptura de fronteiras, tradicionalmente existentes entre os fenômenos naturais e culturais; entre os tempos passadopresente-futuro; entre os gêneros literários, etc., etc. Já não há como ignorar que estamos entrando na era do multiculturalismo. [...] As múltiplas linguagens, antes irredutíveis umas às outras, passam a dialogar entre si. [...] Embora seja difícil detectarmos as causas exatas dessa nova diretriz criadora, arriscamos apontar algumas que parecem evidentes: - a incessante necessidade de renovação do processo criador; - a atual busca de totalidade (para neutralizar a fragmentação do mundo atual); - a crescente preocupação com a possível/impossível comunicação da poesia com o leitor "trabalho" pelos mass-midia e - a necessidade de resgate-reinvenção do passado ou das origens históricas ou míticas (como força-resistência à inevitável "globalização" que avança sobre os "quatro cantos do mundo" e ameaça diluir a identidade cultural de cada povo). 
O multiculturalismo leva a criação de obras em que se misturam elementos de várias matrizes. Temos filmes atuando com trechos de desenhos animados ou quadrinhos, peças de teatro em que a narrativa gráfica surge no cenário, poesia acompanhada de vídeos e/ou músicas, etc. Até mesmo as onomatopéias inseridas na tela entre um soco e outro na extinta série do Batman exibida na televisão durante os anos 60/70 pode exemplificar a integração de linguagens e suportes comunicativos, em que um recurso bastante explorado nos quadrinhos é utilizado para ilustrar cenas que ocorrem num suporte audiovisual, e que por sua vez, adapta aventuras de uma personagem surgida no próprio quadrinho. Vale ressaltar que estamos nos referindo a obras que, no caso específico desse estudo, trazem um hibridismo em relação à estrutura de sua montagem, utilizando suportes distintos numa atuação harmônica para a composição da obra final. Não estamos nos referindo necessariamente à construção de sentidos, uma vez que, nesse caso, precisaríamos considerar até mesmo a elaboração de um texto que traz as marcas do hibridismo em sua confecção. Assim, na relação quadrinhos-literatura que será destacada a seguir, o que procuraremos observar são aquelas obras que, em sua elaboração apresentam trechos expressos pela linguagem literária e outros pela narrativa quadrinizada.

Mais uma vez, entretanto, percebemos que há poucos exemplos dessa forma de interação, tanto em Língua Portuguesa quanto em âmbito mundial. As duas formas de expressão artística, que tanto oferecem em termos de comunicação e expressão, se encontram, numa atuação conjunta, apenas em algumas obras. 
Também aqui teremos uma gradação, só que dessa vez no que diz respeito à participação das duas formas de expressão na construção narrativa: em alguns casos, há uma relação mais auxiliar de um dos suportes em relação ao outro, enquanto em outras situações, tanto literatura quanto quadrinhos contribuem de forma conjunta para a construção da obra. De certo que é possível encontrar em uma mesma obra, diferentes formas de interação (mais auxiliar em alguns momentos e complementar em outros), mas o que será levado em consideração para esse estudo, é a preponderância de determinadas características, permitindo reconhecer de que forma a relação entre os meios artísticos se manifesta de uma maneira geral na obra final.

\section{a) Quadrinhos - ilustrando o literário}

No livro Confronto Mortal de Rosana Rios, literatura e quadrinhos integram a estrutura da obra, sendo que é a linguagem literária o fio condutor da estória, e os quadrinhos surgem pontualmente, apenas em alguns momentos para auxiliar na construção narrativa, ora acrescentando elementos ora ilustrando trechos narrados pela literatura. A quadrinização ao longo da obra é feita por Getúlio Delphim, que apresenta em traços mais realistas, os cenários e personagens descritos no texto literário.

A personagem principal é Edson (ou Déo), um jovem adolescente desenhista de quadrinhos. Ele é o narrador em $1^{\mathrm{a}}$ pessoa dos fatos que aconteceram e que envolvem um antigo personagem de quadrinhos, o Loh, ou Biker, um ciclista de um mundo devastado, 
habilidoso com o chicote e o punhal, e que de certa forma adquire vida própria e passa a controlar e a matar seus desenhistas ao longo do tempo. Percebendo tal fato e contando com a ajuda de sua namorada Janaína e outro desenhista experiente chamado Jan, Edson coloca a personagem que criara tempos atrás, o índio Acauã, que tem o poder de se transformar em ave quando toca a terra, para combater o Loh nas páginas dos quadrinhos. Porém, enquanto as personagens se enfrentam, aqueles que os desenham tem sua energia sugada.

A função ilustrativa/complementar dos quadrinhos na obra pode ser percebida em vários trechos, como quando Acauã é apresentado. Inicialmente Edson descreve a personagem que criará e na seqüência os desenhos quadrinizados ilustram a evolução da personagem, da prancheta de desenho à sua transformação em ave (Fig. 72):

[...] Já fazia tempo que eu inventava hqs e desenhava tiras; mas Acauã era um personagem mais forte (...) Os primeiros desenhos eram tímidos, eu não era lá essas coisas em anatomia humana. Mas desde o princípio ele teve a aparência indígena e o poder de se transformar em ave quando se concentrava e tocava a terra (pág. 12). 


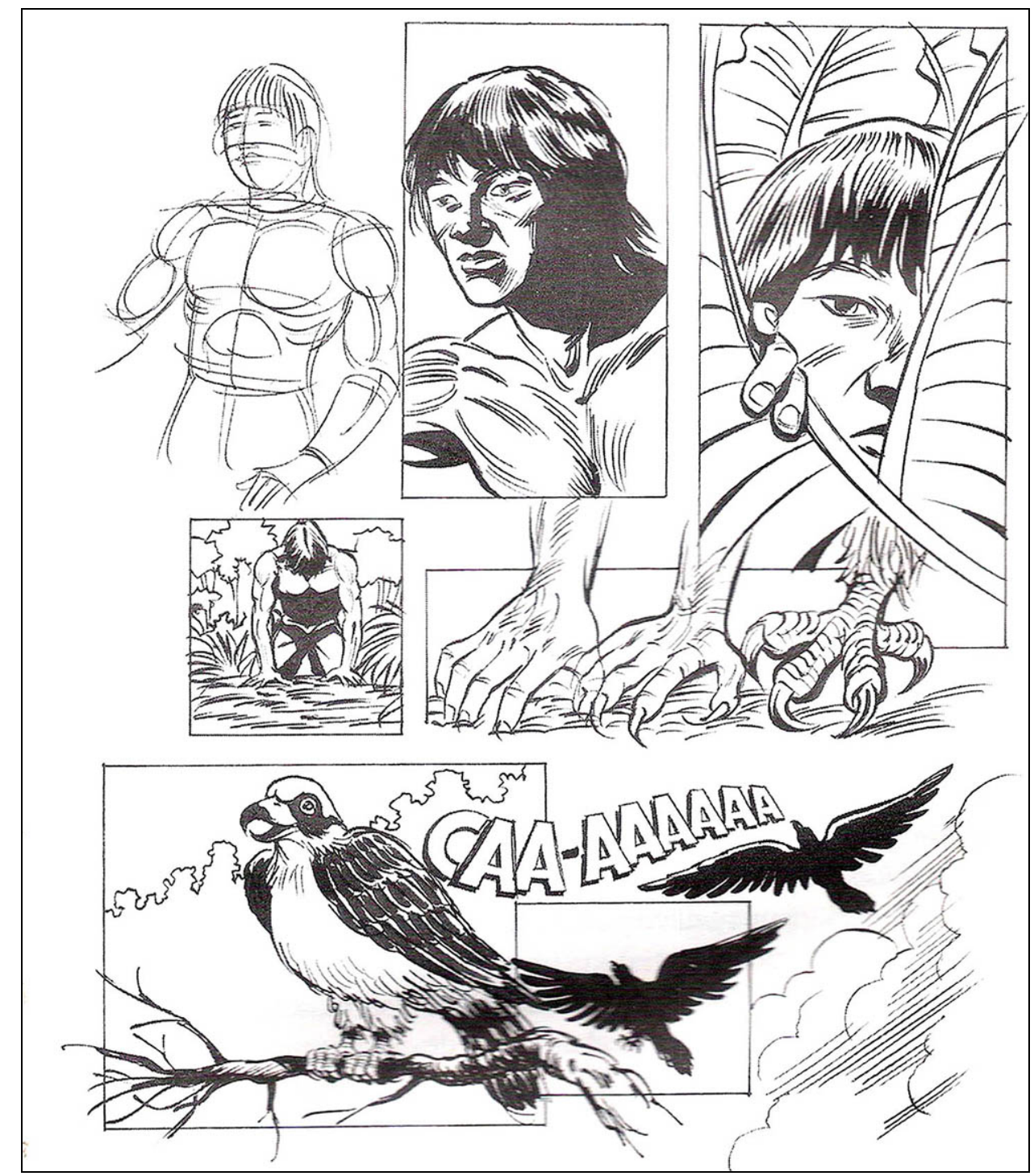

Fig. 72 - Os quadros e desenhos sobrepostos dão agilidade e movimento ao trecho. O esquema da figura de Acauã e sua transmutação em ave são revelados pela figura das mãos que aos poucos viram garras, como num movimento em câmera lenta.

Em outro trecho, quando nos é contado a morte de um dos desenhistas do Biker, também temos os quadrinhos ajudando a narrativa literária a compor a cena:

Na verdade mais adivinhei que li o artigo. Contava como um dos mais conhecidos artistas dos quadrinhos italianos agira de forma estranha nos últimos meses, depois que começara a desenhar um personagem americano, o Biker. (...) só me impressionei com seu suicídio: jogara-se do alto de um edifício (pág. 71). 
Na narrativa em quadrinhos que se refere ao mesmo trecho, vemos a complementação das informações fornecidas pelo texto literário: o assassinato praticado pelo Biker (Fig. 73).

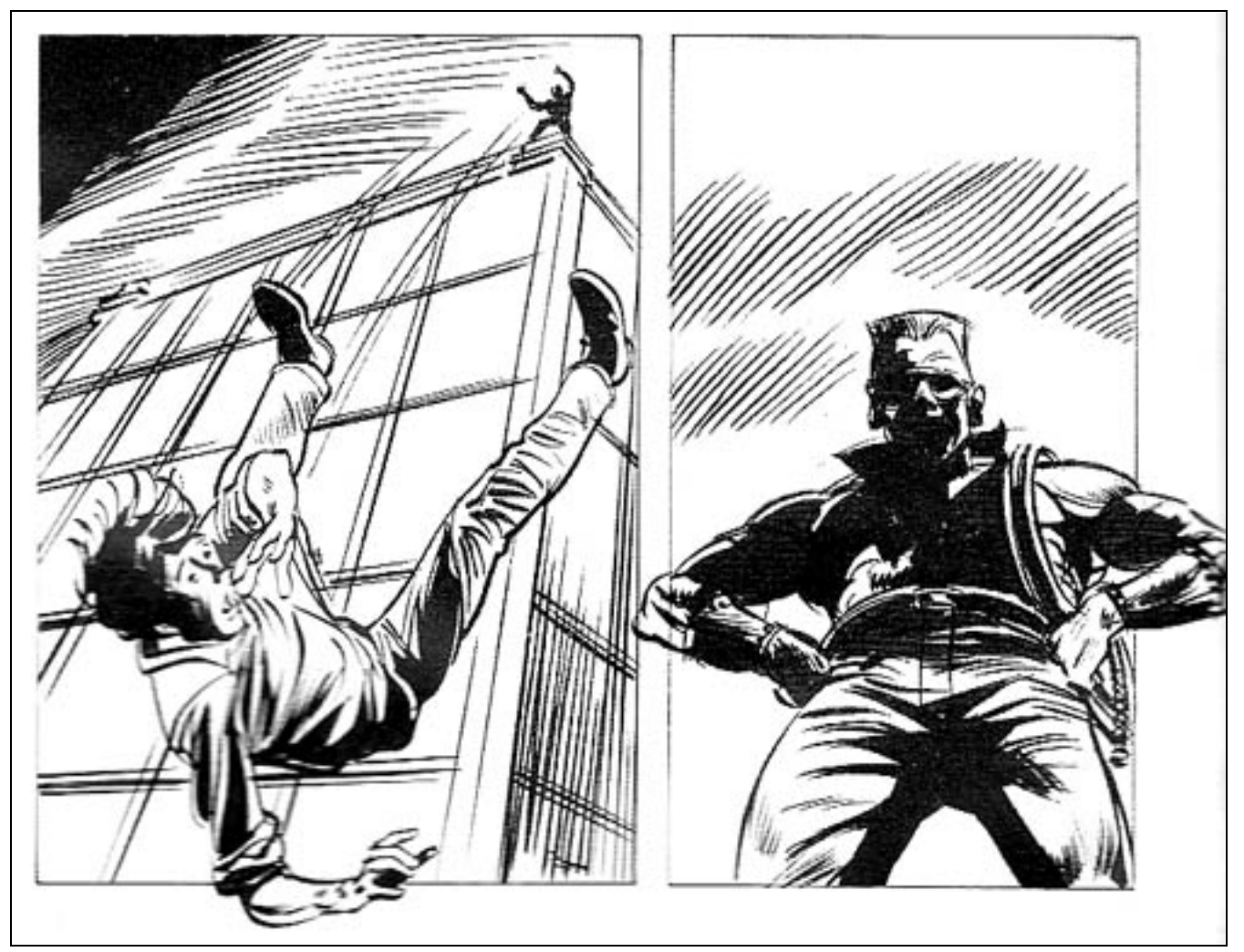

Fig. 73 - O quadrinho explicita elementos que estão subentendidos no texto literário: a ação assassina do Biker.

No combate final entre Acauã e Loh, os quadrinhos assumem a narrativa, numa referência metalingüística ao próprio suporte, uma vez que a luta é realizada por personagens de quadrinhos e ocorre justamente no espaço de uma HQ. A narrativa literária inicia a descrição do confronto, quando os dois desenhistas, Déo e Jan, começam a desenhar respectivamente as personagens Acauã e Loh (págs. 74 e 75): 
Ele [Jan] tomou sua lapiseira de grafite azul e começou a traçar uma cena. Naí imediatamente rabiscou um cenário urbano e me passou o papel. Soube o que Jan quisera dizer com a impaciência de Loh. Acauã saiu de meu lápis apressado, ansioso, como se estivesse apenas esperando que a ponta encostasse na folha. Desenhamos muitos e muitos quadrinhos. Nos dele, Loh rodava pela cidade deserta, furiosamente, à procura de alguém. Nos meus, Acauã se esgueirava entre escombros fumegantes tentando não fazer barulho. [...] Não criávamos nada: éramos apenas intérpretes dos HQs. Havíamos nos colado a Acauã e a Loh. [...] Tínhamos transposto completamente os portais. Agora nos movíamos e respirávamos na dimensão dos HQs.

A partir daí, a estória continua nos quadrinhos. A forma de transição dos quadros, o uso de onomatopéias e de linhas de movimento e a utilização de planos variados dão a impressão de dinamismo e agilidade, o que se coaduna com o episódio narrado: uma luta mortal (Fig. 74). 


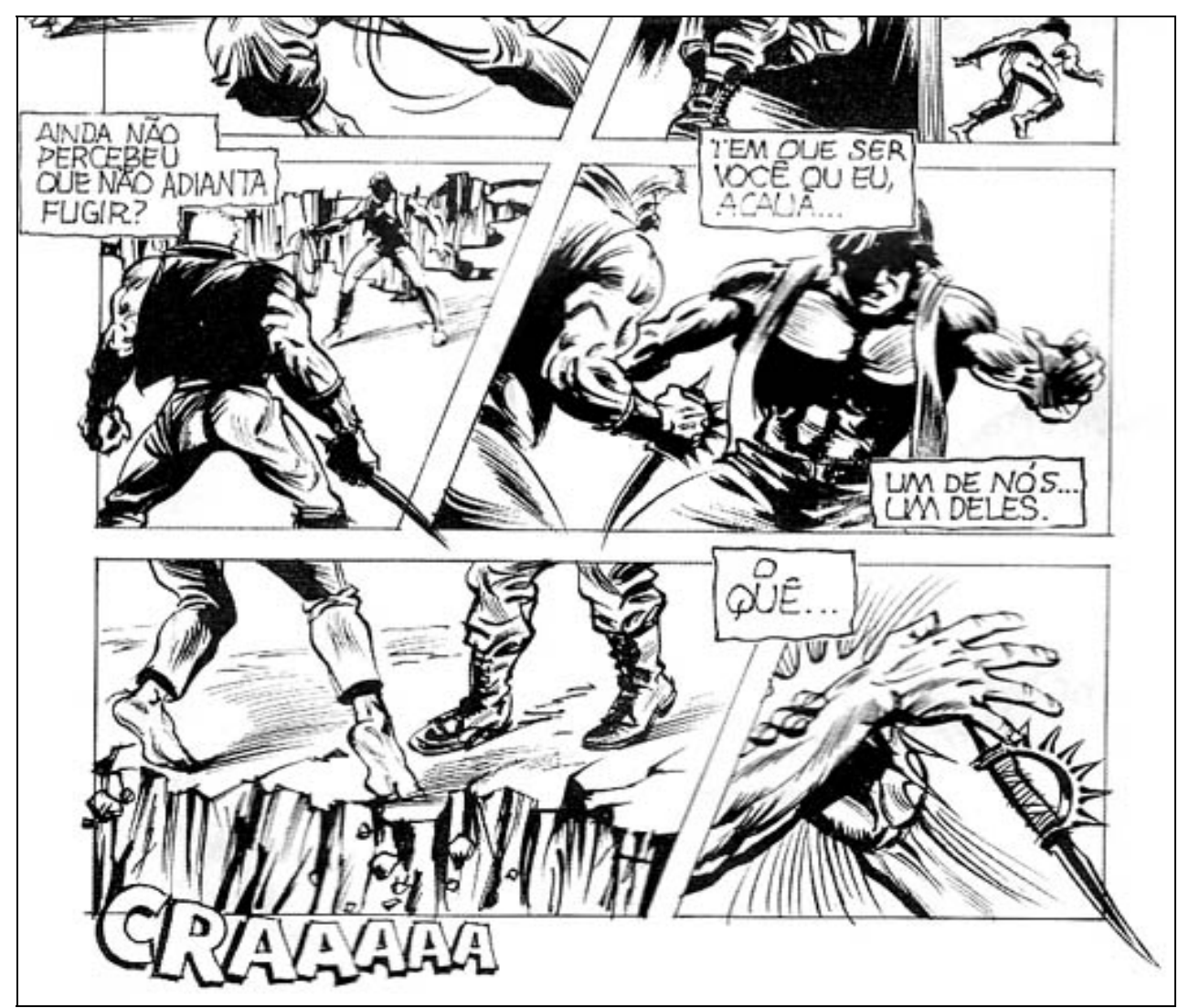

Fig. 74 - No quadrinho, o Biker, ao revelar que apenas um deles irá sobreviver, também se refere aos desenhistas que tem suas energias tomadas pelas personagens que criam naquele momento (e assim como elas, sofrem mortalmente com o combate nas pranchetas de desenho).

Após o trecho da luta entre as personagens dos quadrinhos (com a derrota do Biker) a linguagem das HQs surge apenas em mais alguns momentos na obra e de forma ilustrativa ao texto literário. Essa forma de composição, por sua vez, ainda remete à obra ilustrada, em que os trechos quadrinizados mais ilustram o texto literário do que contam ao longo da estória. De certo que, no momento chave, quando da luta entre as personagens, a narrativa em quadrinhos, coerentemente, assume a condução dos fatos. Contudo, apesar de pouco usado ao longo da narrativa e de assumir função co-referencial ao literário, os quadrinhos ajudam na composição da obra, ainda que, na maioria das vezes, de forma 
auxiliar. Em um uso mais complementar, temos o exemplo seguinte, em que há uma atuação conjunta da literatura e dos quadrinhos numa mesma obra.

\section{b) HQ e literatura: complementaridade narrativa}

A obra Pega pra Kaput de Josué Guimarães, Moacyr Scliar, Luis F. Veríssimo e Edgar Vasques, feita no início da década de 70, traz, além da linguagem verbal, que já vem com a marca da pluralidade uma vez que é realizada por várias mãos, a narração quadrinizada de partes da estória, nesse caso, quando o trecho é produzido pelo autor de quadrinhos Edgar Vasques. Os textos escritos por autores diferentes se integram de maneira unificada e a narrativa quadrinizada se insere naturalmente na obra.

O humor, traço marcante da obra, já vem explicitado no próprio título que remete à expressão popular "pega pra capar”, cuja significação literalmente, seria "pegar para castrar”, mas que popularmente está associada à idéia de confusão, tumulto, briga, etc. No título, a palavra capar é substituída pelo termo alemão Kaput que, segundo definição do escritor Curzio Malaparte (1985, p.3) em seu livro Kaputt (grafado com dois t), significa "quebrado, que se fez em pedaços, que foi à breca”. O livro de Josué Guimarães e

companhia engloba em seu enredo grande parte dessas significações, na medida em que traz em sua trama operação de castração, confusão, perseguições, brigas e muito mais. 
No enredo, nos deparamos com uma estória inusitada: Hitler é operado por um prisioneiro judeu que é médico, e tem o seu testículo que, a propósito, era o único, pois Hitler tinha nascido apenas com um, retirado e guardado em um vidro de conserva. Na verdade Hitler queria fazer uma circuncisão, para poder se disfarçar de rabino. Com o desfecho da guerra o vidro, com seu “precioso" conteúdo, é extraviado e vem parar em praias brasileiras em plena época da ditadura. Ele acaba sendo encontrado por uma inocente dona de casa que, ao abrir o vidro, vê sua vida se modificar através de uma maldição que a persegue: ao abrir qualquer coisa, uma catástrofe acontece. A confusão começa quando alguns remanescentes do regime de Hitler vêm ao Brasil para recuperar o vidro a qualquer custo.

A narrativa literária dos demais autores convive igualitariamente com a narrativa quadrinizada de Edgar Vasques, produzida em preto e branco, com traços estilizados. Aliás, vale destacar que não há uma delimitação, no que diz respeito à narrativa literária, de quem escreve qual parte. Os quadrinhos não surgem simplesmente para ilustrar o texto, mas para inserir novos trechos ao enredo, numa relação complementar.

Assim, na página 21, após sabermos que Hitler será operado por um médico judeu, temos, na seqüência seguinte, a narrativa quadrinizada que continua a estória e narra a operação. Em cena, observamos o médico operar Hitler, ação resumida no último quadro da página, através da posição sugestiva da personagem e das onomatopéias que intensificam a ação (Olé, Cort). As linhas de movimento que acompanham o braço do médico mostram que ele acabara de cortar o testículo de Hitler. Uma figura interessante que surge na 
narrativa em quadrinhos é uma pequena abelha que observa e comenta as cenas, como um alter-ego do narrador (Fig. 75).

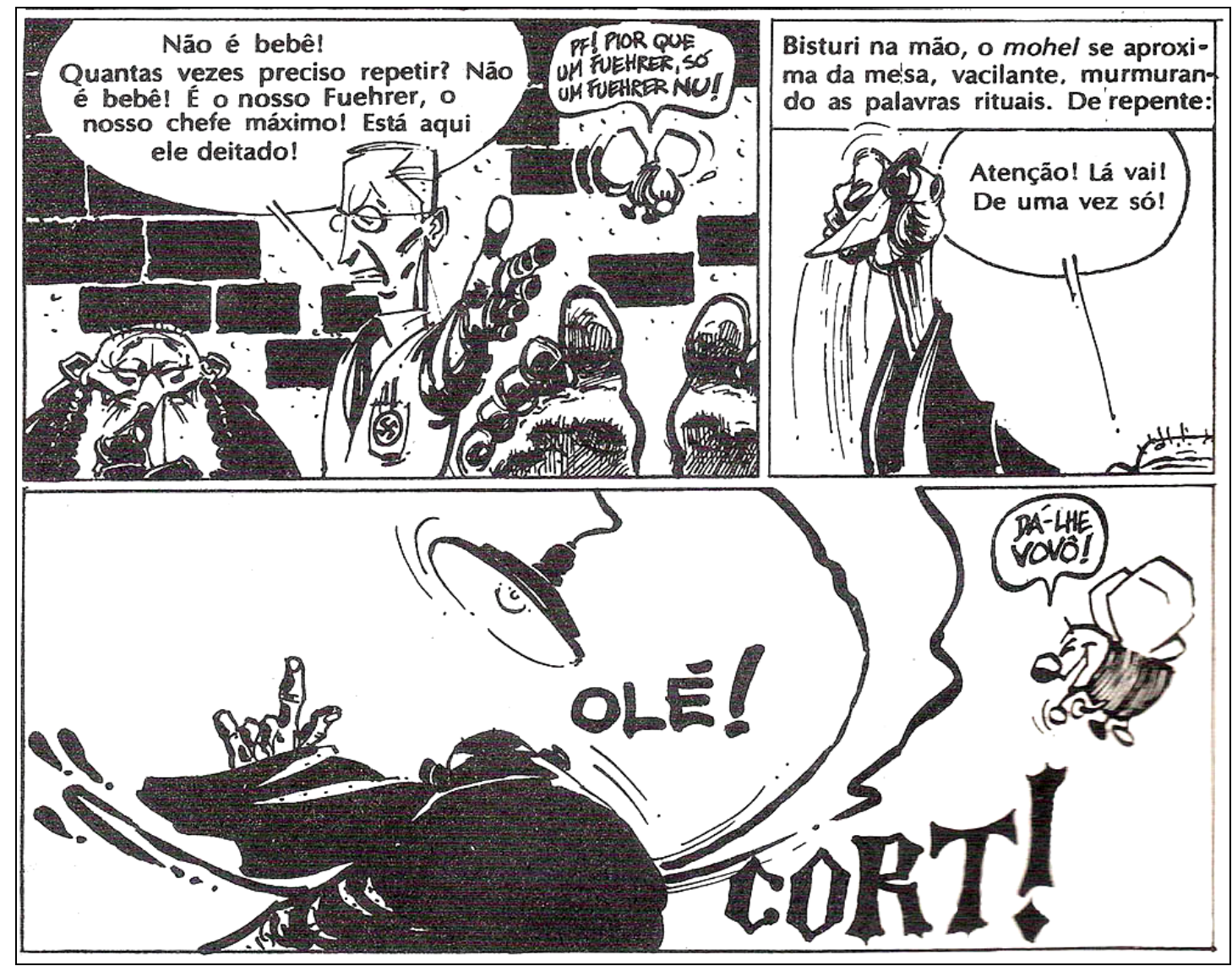

Fig. 75 - Na seqüência, o médico pensa se tratar de uma circuncisão em um bebê. Nas ilustrações, as linguagens verbal e não-verbal se revelam, na maioria das vezes, complementares, em que cada uma traz informações para compor a narração.

O resultado da operação é mostrado logo a seguir: Hitler fica sem os testículos (Fig.

76). A figura do ditador é introduzida na cena metonimicamente pelo desenho de seus pés. 


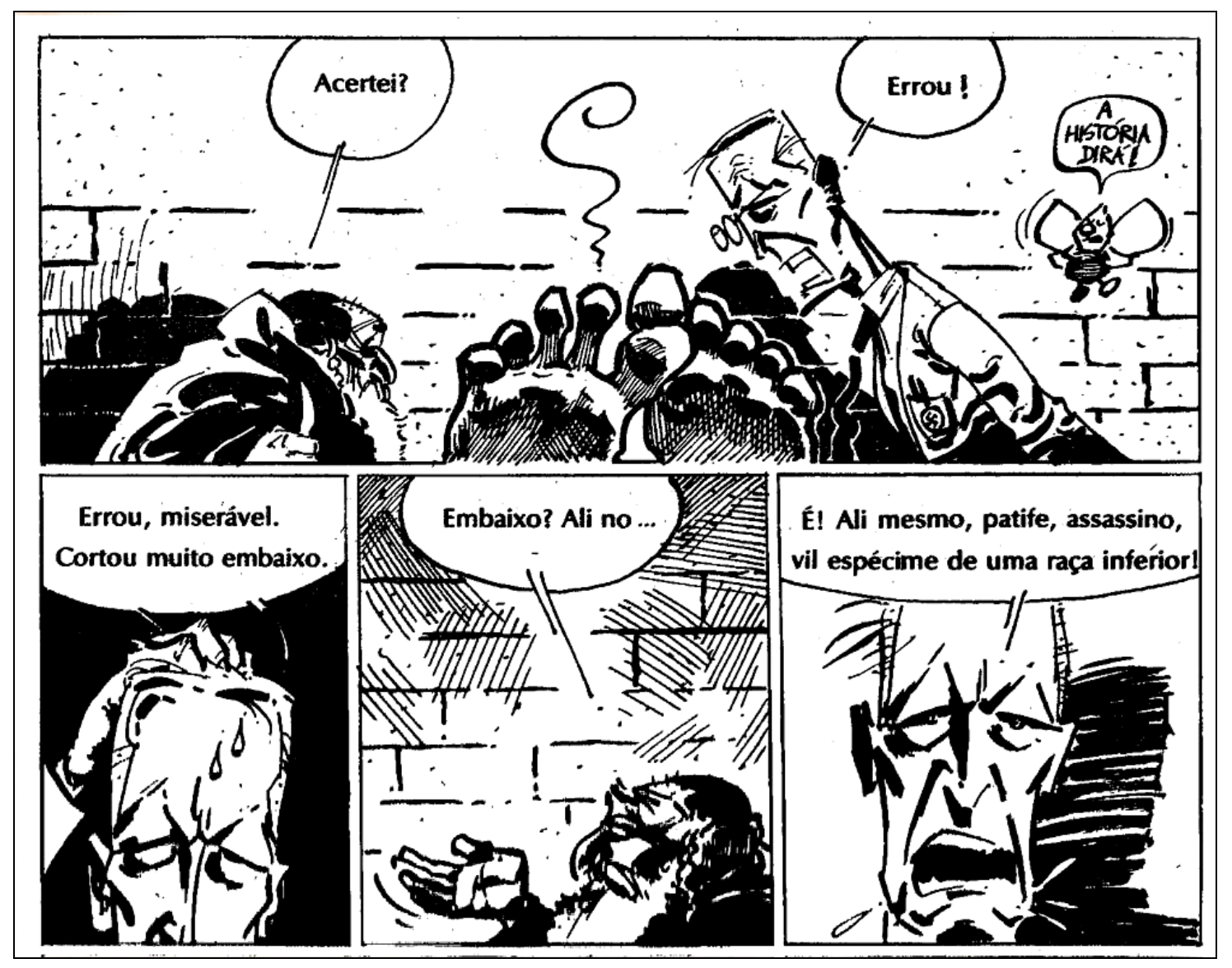

Fig. 76 - As gotas na testa de Morell denunciam o fiasco da operação.

Na página 54, há outro exemplo da inserção da linguagem quadrinizada na estrutura narrativa. No texto literário que antecede os quadrinhos, temos o diálogo entre o Dr. Hans Mayer, clínico alemão que fugira dos nazistas durante a guerra, e Moysés, médico e investigador de ciências ocultas. Eles comentam justamente sobre o vidro e seu misterioso conteúdo (pág. 53):

Mas Hans Mayer não queria falar sobre política. Apontou para o vidro que Moysés lhe trouxera, e que estava sobre a mesa, entre os potes de geléia. Ainda fechado.

_ Eu já lhe contei alguma vez sobre uma certa peculiaridade anatômica de Adolf Hitler?

_Não, Hans. Qual?

_Os testículos. Ele... 
A narrativa literária é então interrompida, e os quadrinhos continuam a contar a estória daquele ponto. A transição é feita de forma fluente, sem que se perca o ritmo da narração. Após a inserção de um único quadro ilustrando o rosto de Mayer em close, somos introduzidos numa seqüência de ações que culminam com o roubo do frasco (Fig. 77).

Um anão, integrante do grupo que tenta resgatar o testículo de Hitler, é então capturado pela governanta do Dr. Hans Mayer. As ilustrações mostram a reação do anão ao ser capturado e seu espanto ao reconhecer o vidro e seu conteúdo. A utilização de símbolos para representar palavrões, recurso bastante comum nos quadrinhos, é feita de forma humorística, pois o autor faz uso de figuras nada comuns para essa forma de representação: lagartixa, suástica nazista, etc. Tal fato se dá porque, como é afirmado, não se trata de qualquer palavrão, mas os proferidos por um “anão alemão”. 


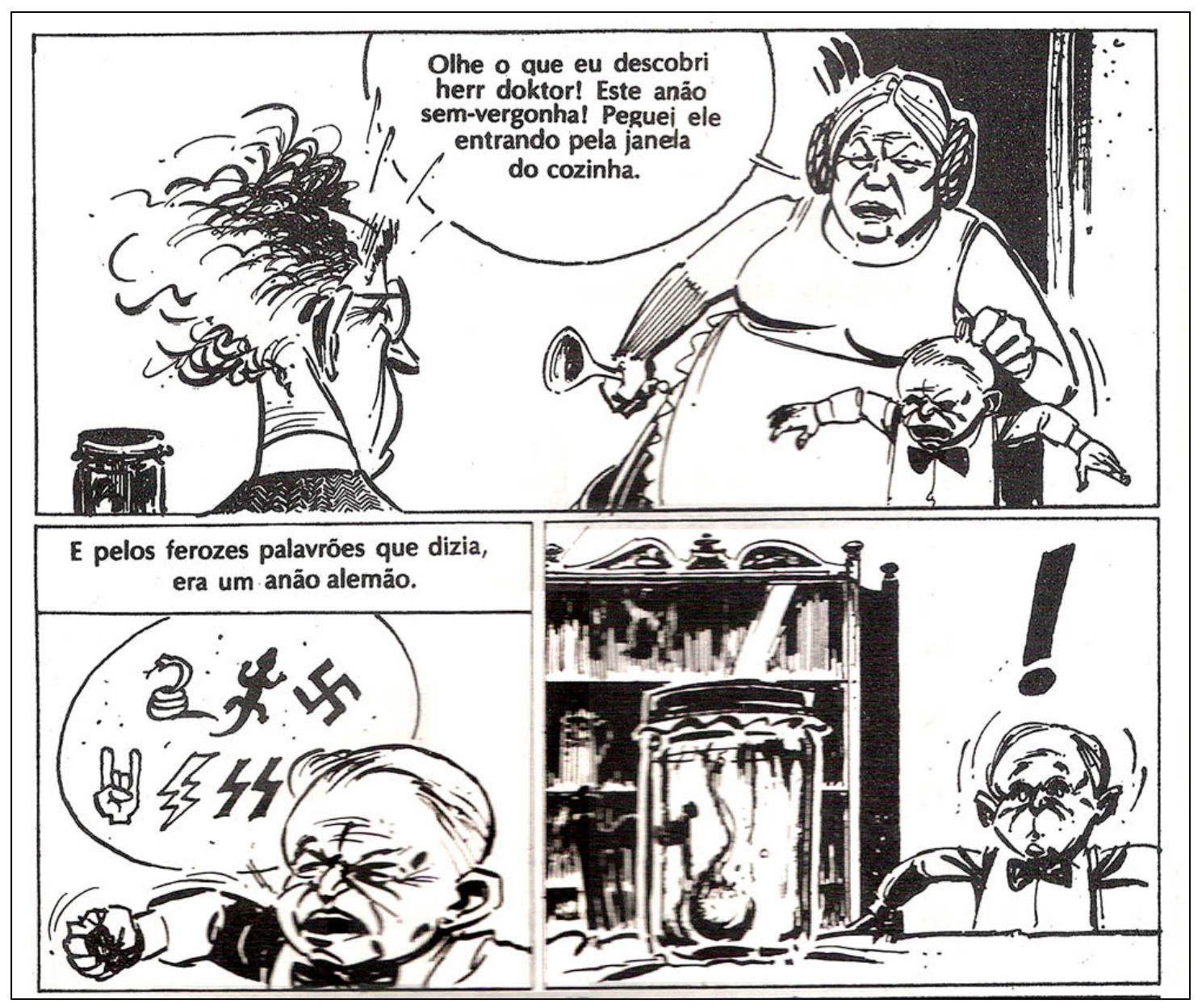

Fig. 77 - O espanto do anão no terceiro quadro é representado por um enorme sinal de exclamação.

Ao final do livro, num diálogo metalingüístico com a própria obra e seus autores, Vasques encerra a estória. É importante ressaltar que o diálogo interno entre os autores e a obra em si já se iniciara em trechos anteriores, pela narrativa verbal, quando a personagem Gudinho, professor aposentado de contabilidade e vizinho de Dona Rachel, a senhora que encontrara o vidro anos atrás e o abrira por engano, encontra-se com os autorespersonagens do livro em um vôo. Na página 120, o trecho que antecede a narrativa 
quadrinizada cita os três escritores-personagens, responsáveis pelos trechos da narrativa literária da obra, no momento em que uma das personagens do livro pega um avião:

Platão entrou no avião, sentou-se, inquieto. Já na sala de espera tivera a atenção atraída para os três homens - os dois de barba, e o outro. Perguntou à aeromoça à respeito. São escritores, ela dissera, mas Platão continuava desconfiado, e mais desconfiado ficou ao ver que os três sentavam atrás dele. [...]

O avião acabava de decolar. Platão levantou-se, foi até a porta dos fundos e antes que a aeromoça conseguisse detê-lo - abriu-a e saltou.

A partir daí, o quadrinho continua a última parte da estória. Na seqüência que se encaminha para o final, vemos caricaturalizados, Scliar, Veríssimo e Josué. Em um avião eles discutem o destino final das personagens do livro. No último quadro, a imagem do vidro com seu precioso conteúdo, perdido no meio do cerrado e "olhando zombeteiro” para o avião onde se encontram os autores, sugere ironicamente que a obra, e a maldição que acompanha o vidro, se voltam contra seus próprios criadores (Fig. 78). 


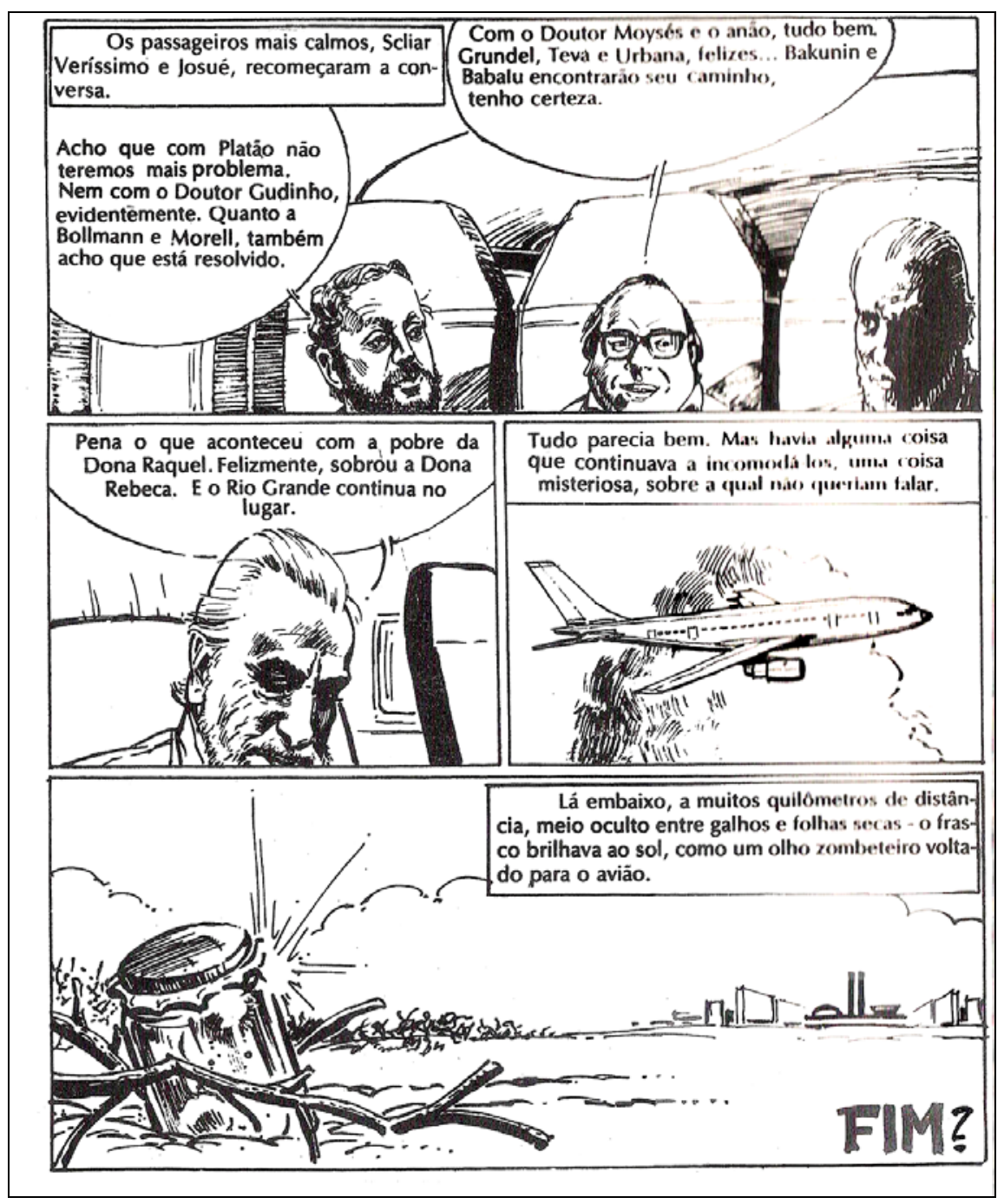

Fig. 78 - É a linguagem verbal que, na seqüência final, fornece as informações necessárias para que compreendamos o desfecho irônico da estória.

Os traços estilizados de Vasques se coadunam com o texto bem-humorado dos outros autores, fluindo normalmente, o que revela a força comunicativa dos dois meios e as diversas possibilidades inter-relacionais que se pode estabelecer entre ambos. A interação do leitor com a obra e o aspecto lúdico presente na mesma se dá naturalmente, na medida em que a transição de uma forma de narrativa para outra ocorre de maneira fluente. 


\subsubsection{Intercruzamentos narrativos}

As formas de relação que podem ser estabelecidas entre os quadrinhos e a literatura não se resumem a transposições de obras literárias para as HQs. A adaptação de obras em quadrinhos ou elementos oriundos do mesmo para a literatura, apesar de pouco comum, também gera inúmeras formas de interação, como pudemos verificar. Assim como ocorre na adaptação do material literário para os quadrinhos, as obras produzidas no movimento contrário apresentam uma gradação em que podemos ter desde uma aproximação até um distanciamento do texto-base. Na paródia que Scliar faz do famoso Capitão Marvel temos um exemplo de como o diálogo mais distanciado entre a obra literária e os quadrinhos pode ocorrer.

Os recursos oferecidos pelos quadrinhos, e que hoje é amplamente compartilhado com outros suportes, como a televisão e o cinema, revelam como a arte das HQs, como toda expressão artística, produz elementos que passam a fazer parte de determinado cânone, tornando-se consagrado para certo público. Capitão Marvel ou Shazam faz parte do universo dos heróis com poderes incomuns, e a sátira de Scliar trava um diálogo com toda uma tradição, numa forma de questionar, inovar e até mesmo homenagear tais elementos. Por meio do humor, o autor estabelece uma “ponte” que vai além da personagem, chegando aos próprios cânones dos quadrinhos.

Tal fato também revela o modo como a sociedade e a cultura de uma maneira geral produzem e se relacionam com determinados elementos da tradição. Nos quadrinhos, grande parte dos cânones que transitam em seu universo está ligado à história do seu 
surgimento e expansão. Foi nos EUA que as HQs se consolidaram e encontraram uma forte indústria de produção e distribuição, daí vir desse país, grande parte dos elementos de tradição das HQs que conhecemos atualmente, sendo um dos principais deles, os super heróis.

No obra Livros de Magia, ao contrário do que ocorre no conto de Scliar, a transposição literária procura traduzir de forma fiel o universo apresentado na HQ. Nesse caso, é a linguagem verbal que corporifica a visualidade presente na obra-base. Tanto a satirização de Scliar quanto a adaptação de Carla Jabonski apresentam elementos que exploram diferentes formas comunicativas, uso variado dos recursos textuais para representar elementos oriundos da visualidade dos quadrinhos e, principalmente, as possibilidades comunicativas dos quadrinhos que, enquanto arte expressiva, fornece material que pode ser usado também para o desenvolvimento de obras literárias.

Já a participação dos quadrinhos e do texto literário para a criação de uma obra conjunta apresenta outra proposta de construção. A gradação agora se apresenta quando verificamos a participação dos dois meios expressivos na composição da narrativa final. Em alguns casos, um dos meios assume uma posição submissa em relação ao outro, como ocorre no livro Confronto Mortal, em que a linguagem quadrinizada, em grande parte da obra, surge de maneira auxiliar ao texto literário. Em Pega pra Kapput, por sua vez, no qual tanto os quadrinhos quanto o material literário atuam de maneira unificada para construir a estória final, a relação que se estabelece entre os dos dois meios é de complementaridade, em que cada um ajuda a contar a estória. 


\section{CONCLUSÃO}

A história em quadrinhos em sua relação com o material literário tem produzido obras que apresentam uma grande diversidade de formas de composição, como pudemos observar. O quadrinho, por seu lado, apresenta na união entre as linguagens verbal e nãoverbal, maneiras próprias de construir narrativas, fato, aliás, que o aproxima do próprio “fazer” literário, cuja narratividade é uma de suas principais marcas. Nesse sentido, vale destacar que ao se refazer o caminho histórico do encontro entre as linguagens visual e verbal, percebemos que tanto uma quanto outra tem sido veículo eficiente para as sociedades contarem suas histórias ou feitos e registrarem suas experiências de vida desde os tempos das cavernas.

Nos quadrinhos, é a união entre as linguagens do olhar e da palavra que propicia a organização do código narrativo, cujos elementos fazem parte da estrutura de qualquer narração, independente do suporte que a veicule. A materialização dos elementos narrativos como personagem, espaço, tempo, etc., é expressa por meio da visualidade imagética nas HQs, aspecto importante de sua constituição e que será vital para o diálogo com o material literário que, por sua vez, revela recursos próprios de composição, organizados pela linguagem verbal.

A intersecção entre esses meios se dá através de diferentes maneiras de elaboração, como foi destacado ao longo desse estudo. A contribuição de tais diálogos para a cultura atual, por sua vez, reside nas várias possibilidades que eles podem oferecer, dependendo da 
arte com que forem realizados. Nesse sentido, destaca-se a possível “releitura” de aspectos da tradição, trazendo-os para novas chaves, contextos e interpretações, oferecendo elementos para enriquecer o processo comunicativo, com múltiplas leituras e usos, e não nos referimos apenas às pedagógicas, mas também à fruição. O que se observa nos diferentes diálogos que se estabelecem entre os meios é que, quanto mais interativa se der a relação entre os quadrinhos e o material literário, ou quanto mais “aberta” se mostrar essa relação à variadas formas interpretativas, maiores são as possibilidades de interação com a obra final. Portanto, uma adaptação mais didatizada, que faz uso burocrático dos recursos dos quadrinhos e da visualidade inerente ao mesmo, corre o risco de se tornar pouco eficiente na interação com o leitor.

As obras destacadas ao longo desse trabalho apresentam várias propostas de diálogo o que, conseqüentemente, resulta em diferentes formas de interação com elementos oriundos da tradição cultural. É o que foi visto nas análises que trazem desde obras em que o diálogo serve como facilitador de leitura até aquelas em que são criados textos inovadores, seja nas HQs ou na literatura quando dialoga com os quadrinhos, seja na interação dos dois suportes.

Na adaptação de $A$ Moreninha para os quadrinhos o que se percebe é uma busca por aproximar o leitor dos clássicos. Na obra, a linguagem das HQs se subordina à obra original, guia principal da criação. Em Gaetaninho também é possível identificar o mesmo objetivo, apesar de haver um maior uso da visualidade presente nos quadrinhos, o que dá mais dinamicidade à obra e a torna mais ágil e próxima do leitor que se identifica com tal 
visualidade. Já propondo a inserção de elementos novos à obra-base, Lusíadas 2500 oferece uma nova forma de interação com o poema épico de Camões, agora transformado numa ficção científica. Na mesma linha, porém realizado de outra maneira, a quadrinização de Branca de Neve, estabelece uma relação diferente com o conto tradicional, que passa a ser representado como um jogo de peças, um painel fotográfico. Tanto Lusíadas 2500 quanto Branca de Neve se configuram como adaptações criativas que não se limitam a reproduzir o texto-base, mas integrar a ele outras formas de concepção. Algumas das produções realizadas nessa linha também revelam o objetivo de aproximar a obra clássica do leitor moderno. A eficiência de tal intento, entretanto, vai depender do modo como é feita a inserção de novos aspectos ao enredo original e qual a fluência do uso dos recursos do novo suporte.

No âmbito dessa tendência, tivemos contato com narrativas em quadrinhos que, dialogando com o material literário, alteram o texto-base com elementos oriundos de novas chaves (humor, terror, suspense, etc.), permitindo assim uma maior interatividade com os clássicos, o que produz inovações e questionamentos dos mais diversos. Na paródia de $O$ Patinho Feio ou nas aventuras protagonizadas pelas personagens da turma de Níquel Náusea, o humor dá a tônica para a desconstrução de obras clássicas dos Contos Infantis. É por meio do humor que cânones tradicionais da literatura são questionados e renovados. Em outra chave (terror), o diálogo entre a personagem dos quadrinhos, Sandman e a obra de Shakespeare, Sonhos de Uma Noite de Verão, colocam frente a frente elementos integrantes da tradição dos dois meios. 
Num movimento contrário, o do elemento literário (verbalização, diálogos, etc.) que se apropria de recursos, personagens e outros aspectos das HQs, temos em geral a desmistificação de figuras consagradas, como é o caso do conto de Scliar, Shazam, em que o Capitão Marvel e seus superpoderes são satirizados pela narrativa verbal, por meio de um diálogo em que um elemento chave dos quadrinhos (o super herói) é desconstruído pelo humor, pelo riso, um dos processos mais eficazes para "dessacralizar o sagrado”. Os Livros da Magia revelam, por sua vez, uma adaptação pouco comum de obra em quadrinhos para a literatura, na medida em que aponta para uma forma de pastiche, que procura reproduzir a obra original na íntegra, transportando por meio da linguagem verbal, toda a visualidade dos quadrinhos.

No sentido de mostrar que as possibilidades interativas entre os dois suportes não se esgotam em adaptações e diálogos entre os textos, foram apresentadas obras que resultam do entrelaçamento das duas linguagens: a dos quadrinhos e a da literatura. Em Confronto Mortal, o texto verbal literário se desenvolve com a ajuda da linguagem quadrinizada para contar a estória. Já em Pega pra Kapput, os quadrinhos surgem de maneira complementar ao texto literário e narra, juntamente com este, trechos da narrativa. Tais formas de interação revelam quão ricos podem ser os diálogos entre obras e suportes, permitindo novas possibilidades de integração do lúdico e propondo outras maneiras de leitura.

Apesar de tantas possibilidades comunicativas que o diálogo entre os quadrinhos e o material literário oferece, como elencado até aqui, temos ainda pouca produção, divulgação e consumo das obras que realizam tal intento. De certo que foi ampliado ao longo dos anos 
(falando-se especificamente na produção nacional) o reconhecimento da HQ como recurso pedagógico, porém na escola, instituição oficial que homologa o uso dos quadrinhos como ferramenta de ensino-aprendizagem, a concepção pedagógica que prevalece é aquela que vê nas HQs um recurso auxiliar para o aprendizado, não reconhecendo nele, sobretudo no diálogo com o literário, uma forma autônoma de leitura, daí seu uso estar restrito, nesse caso, à mediação entre o leitor e as obras tradicionais da literatura. O que se percebe, portanto, é que a sociedade ainda carece de um conhecimento mais profundo sobre o quadrinho e as possibilidades comunicativas que ele oferece.

O quadrinho, meio de comunicação de massa e importante produto da indústria cultural, apresenta forte apelo visual e uma linguagem própria, além de ser uma arte que apresenta múltiplas formas de composição. Na produção de língua portuguesa, sobretudo no Brasil, a produção de obras em quadrinhos que realizam o diálogo com o literário aponta para uma aplicação mais pedagógica, entretanto, sua função não se restringe ao uso didático como instrumento de facilitação e mediação entre o leitor e as obras clássicas. Ele também possibilita a fruição. Na verdade o quadrinho apresenta novas possibilidades de criação de textos e novas formas de leitura. É uma arte que, ao contrário do que vulgarmente se pensa, precisa ser apreendida e compreendida. A HQ é um meio que pode servir a muitos fins, como o de despertar um olhar criativo, o raciocínio rápido, a concatenação de idéias, o domínio de técnicas variadas de composição e da exploração do visual. Pode ser um meio de formação de leitores, não passivos como meros receptores, mas ativos, colaboradores decisivos no processo de decifração da leitura ou de construção de novos textos. 
Nosso trabalho, portanto, pretende ser uma contribuição eficaz para a extensa caminhada no processo de conhecimento das múltiplas possibilidades oferecidas pelos quadrinhos em sua relação com o material literário. Esperamos que nosso estudo se junte a muitos outros que venham trazer mais elementos para, inclusive, questionar e inovar o que até então conhecemos, possibilitando assim, o reconhecimento e a expansão das HQs como importante ferramenta de comunicação do nosso tempo. 


\section{BIBLIOGRAFIA}

ANDRADE, Rosane de. Fotografia e antropologia: olhares fora-dentro. São Paulo: Estação Liberdade; EDUC, 2002.

ASSOCIAÇÃO BRASILEIRA DE NORMAS TÉCNICAS. NBR 10520: informação e documentação: apresentação. Rio de Janeiro, 2002.

ASSOCIAÇÃO BRASILEIRA DE NORMAS TÉCNICAS. NBR 6023: informação e documentação: referências: elaboração. Rio de Janeiro, 2002.

ASSOCIAÇÃO BRASILEIRA DE NORMAS TÉCNICAS. NBR 14724: informação e documentação: trabalhos acadêmicos: apresentação. Rio de Janeiro, 2002.

ATAIDE, Vicente. A narrativa de fiç̧ão. Curitiba: Ed. dos professores, 1972.

AZEVEDO, Ricardo. A imagem invade os livros - Diferentes tipos de imagens para diferentes tipos de texto. TVE Brasil, 2002. Disponível no site:

http://www.tvebrasil.com.br/salto/boletins2002/lii/liitxt3.htm. Acessado em dezembro de 2006.

BACELAR, Jorge. A linguagem e a escrita. Universidade da Beira Interior- Texto de Apoio para a Disciplina de Artes Gráficas | Licenciatura em Ciências da Comunicação. Disponível em: http//:www.simaocc.home.sapo.pt/e-iblioteca/pdf/agraficas_texto1.pdf. Acessado em: 06/03/2007

BAKHTIN, Mikhail. Marxismo e Filosofia da Linguagem. São Paulo: Hucitec, 1999. . Questões de literatura e de estética. $4^{\mathrm{a}}$ ed. São Paulo: Unesp, 1998. A Cultura popular na Idade Média e no Renascimento: o contexto de François Rabelais. São Paulo: Hucitec, 1999.

BARBIERI, Daniele. Los lenguajes del cómic. Barcelona: Paidós, 1993.

BARBOSA, Pedro. Arte, comunicação e semiótica. Porto: Edições Universidade Fernando Pessoa, 2002. 
BARROS, Ana e SANTAELLA, Lucia. Midias e Artes. São Paulo, 2002.

BARTHES, Roland. O prazer do texto. São Paulo: Perspectiva, 1974. . Elementos de semiologia. Tradução Izidoro Blinkstein. $5^{\mathrm{a}}$ ed. São Paulo: Cultrix, 1977.

BAZIN, André. O cinema - ensaios. São Paulo: Brasiliense, 1990.

BENJAMIN, Walter. “A obra de arte na era da sua reprodutibilidade técnica" in A idéia do cinema. Rio de Janeiro: Civilização Brasileira, 1969. . Obras escolhidas. São Paulo: Brasiliense, 1985.

BERGSON, Henri. O Riso: Ensaio sobre a significação do cômico. Rio de Janeiro: Ed. Zahar, 1987.

BETTELHEIM, B. A psicanálise dos contos de fadas. Tradução Arlene Caetano. Rio de Janeiro: Paz e Terra, 1980.

BETTON, Gérard. Estética do cinema. São Paulo: Martins Fontes, 1987.

BLOOM, Harold.Shakespeare: a invenção do humano. Tradução José Roberto O’Shea. Rio de Janeiro: Objetiva, 2000.

BORDWELL, David. Narration in the Fiction Film. Madison: University of Wiscosin Press, 1985.

BORGES, Lien Ribeiro. Quadrinhos: Literatura gráfico-visual. Disponível em: http://www.eca.usp.br/agaque/agaque/ano3/numero2/agaquev3n2_1.htm Acessado em $22 / 01 / 2008$

BOTTÉRO, Jean et al. Cultura, pensamento e escrita. Tradução Rosa Maria Boaventura e Valter Lellis Siqueira. São Paulo: Editora Ática, 1995. 
BRAIT, Beth. A personagem. São Paulo: Ática, 1985.

(Org). Bakhtin, dialogismo e construção do sentido. Campinas:

Unicamp, 1997.

BRANDÃO, Helena H. Nagamine. Introdução à Análise do Discurso. $7^{\mathrm{a}}$ ed.

Campinas: Unicamp, 2002.

BURKE, Peter. Hibridismo Cultural. São Leopoldo/RS: Unisinos, 2003. . A Estrutura do Texto Artístico. Lisboa: Editorial Estampa, 1978.

CAGNIN, Antônio Luis. Os quadrinhos. São Paulo: Ática, 1975. . “130 anos do Diabo Coxo” In Comunicação e Educação. Ano I, $\mathrm{n}^{\mathrm{o}}$ 1, São Paulo, 1994.

. "Yellow Kid, o moleque que não era amarelo". In Comunicação e Educação. Ano III, nº 7, São Paulo, 1996.

CALAZANS, Flávio (org.). As histórias em quadrinhos no Brasil - teoria e prática. São Paulo: Intercom; Unesp; Proex, 1997. . Histórias em quadrinhos na escola. São Paulo: Paulus, 2004.

CALVINO, Ítalo. Por que ler os clássicos. Companhia das Letras, 1998.

CAMPOS, Theresa Catharina de Góes. Antecedentes dos manuscritos e impressos. Disponível em: http://www.abn.com.br/arttheca2ante.htm Acessado em 22/01/2008

CANDIDO, Antonio. Literatura e sociedade. São Paulo: T.A. Queiroz, 2000; Publifolha, 2000. sobre Azul, 2006. . Formação da literatura brasileira. $10^{\mathrm{a}}$ edição. Rio de Janeiro: Ouro

CARDOSO, Marcelo Zikán. Como as histórias em quadrinhos vêem o Brasil: de Agostini a Hugo Pratt. 2000. Dissertação (Mestrado em Comunicação). Escola de Comunicação e Artes, Universidade de São Paulo, São Paulo, 2000.

CARPEAUX, O.M. História da Literatura Ocidental. Rio de Janeiro: Cruzeiro, 1960. 
CARRAMILLO NETO, Mário. Contato imediato com a produção gráfica. São Paulo: Global, 1987.

CARVALHAL, Tânia Franco. Literatura Comparada. São Paulo: Ática, 1986.

CIRNE, Moacy, Quadrinhos, sedução e paixão. Petrópolis: Vozes, 2000. . Vanguarda: um projeto semiológico. Petrópolis: Vozes, 1975. . Para ler os quadrinhos: da narrativa cinematográfica à narrativa quadrinizada. Petrópolis: Vozes, 1972.

CLÜVER, Claus. “Estudos Interartes” In Revista literatura e Sociedade (2). São Paulo, USP, 1997, p.37-54.

COELHO, Nelly Novaes. A literatura infantil: história, teoria e análise - das origens orientais ao Brasil de hoje. São Paulo: Quiron, 1981. São Paulo: Quíron, 1984. . Panorama histórico da literatura infantil e juvenil. $3^{\mathrm{a}}$ ed. rev. . O conto de fadas. São Paulo: Editora Ática, 1987. . Literatura e linguagem. São Paulo: Vozes, 1994. . Épica e modernidade na Literatura Infantil/Juvenil. $9^{\text {a }}$ Unidade do curso de Extensão Universitária “Épica e Modernidade”, promovido pelo Centro de Estudos Portugueses/USP, out/nov, 1987. . A poesia - espaço de convergência de multilinguagens. In IV Encontro de Estudos Comparados de Literatura de Língua Portuguesa/USP, 04 e 05, agosto, 1999. Ótica da Complexidade - A articulação dos saberes. Universidade de São Paulo. Disponível em: http://edgarmorin.sescsp.org.br/arquivo/download/arquivos/Nely_02.doc Acessado em $15 / 02 / 2007$. . Do Ermo à Urbe: “As Fugas do Sol”. Ceará: Jornal de Poesia, 2007. Disponível em: http://www.secrel.com.br/jpoesia/nelly.html. Acessado em: $12 / 2007$.

COUPERIE, Pierre, et al. História em Quadrinhos e Comunicação de Massa. São Paulo: Ed. Delta, 1970.

CUNHA, Maria Zilda da. A tessitura dos signos: Matrizes de linguagem e pensamento na literatura infantil e juvenil em obras de Ângela Lago e Octaviano Correia. 2002. Tese (Doutorado em Estudos Comparados de Literaturas de Língua portuguesa) Departamento de Letras Clássicas e Vernáculas - FFLCH, Universidade de São Paulo, 
São Paulo, 2002.

DESCARTES, R. Discurso do método. São Paulo: Martins Fontes, 1996.

DICIONÁRIO INFORMAL: http://www.dicionarioinformal.com.br/definicao

DIRINGER, David. A escrita. Lisboa: Editorial Verbo, 1971.

DISCINI, Norma. Intertextualidade e conto maravilhoso. São Paulo: Humanitas, 2002.

DORFMAN, Ariel e JOFRÉ, Manuel. Super-Homem e seus amigos do peito. Rio de Janeiro: Paz e Terra, 1978.

ECO, Umberto, Apocalípticos e integrados. São Paulo: Perspectiva, 2004.

EISENSTEIN, Sergei. A forma do filme. Rio de Janeiro: Jorge Zahar, 2002. . O sentido do filme. Rio de Janeiro: Jorge Zahar, 2002.

EISNER, Will. Narrativas Gráficas. São Paulo: Devir, 2005.

FEATHERSTONE, Mike. O Desmanche da Cultura: globalização, pós-modernismo e identidade. Tradução Carlos Eugênio Marcondes de Moura. São Paulo: Studio Nobel SESC, 1997.

FEIJÓ, Mário. Quadrinhos em ação: um século de história. São Paulo: Moderna, 1997.

FERRARA, Lucrécia D’Alessio. Olhar periférico. São Paulo: EDUSP, 1989.

FORSTER, E.M. Aspectos do romance. $2^{\mathrm{a}}$ edição. Porto Alegre, Editora Globo, 1974.

FOUCAULT, Michel. As Palavras e as Coisas. Tradução Salma Tannus Muchail. São Paulo: Martins Fontes, 1999. 
GASCA, Luis e GUBERN, Roman. El discurso del cómic. Madri: Ediciones Cátedra, 1991.

GENETTE, Gerard. Discurso da narrativa: ensaio e método. (Trad. Fernando Cabral Martins). Lisboa: Arcádia, 1979.

GÓES, Lúcia Pimentel e FURNARI, Eva (il.). Olhar de Descoberta. São Paulo: Ed. Paulinas, 2003. . Introdução à literatura infantil e juvenil. São Paulo, Pioneira, 1984.

GONÇALO JUNIOR. A Guerra dos Gibis: a formação do mercado editorial brasileiro e a censura dos quadrinhos, 1933-64. São Paulo: Companhia das Letras, 2004. . Biblioteca dos quadrinhos. São Paulo: Opera Graphica, 2006.

GONÇALVES, Aguinaldo José. Relações Homológicas entre Literatura e Artes Plásticas. In Revista Literatura e Sociedade (2). São Paulo, USP, 1997, p.56-68.

GOTLIB, Nádia Battella. Teoria do conto. São Paulo, Ática, 2003.

GREGORIN FILHO, José Nicolau. A roupa infantil da literatura. 1995. Dissertação (Mestrado em), Faculdade de Ciências e Letras da Universidade Estadual Paulista “Júlio de Mesquita Filho”, Campus de Araraquara, UNESP, São Paulo, 1995.

GUAZZELLI, Iara. O conceito de solo epistemológico. In Cadernos de Filosofia do Instituto Sedes Sapientiae, Ano I, no. 1, 1994.

GUBERN, Román. Mensajes iconicos en la cultura de masas. Barcelona: Editorial Lumen, 1988.

HAUSER, Arnold. História Social da Literatura e da Arte. Trad. Walter H. Geenen. São Paulo, Editora Mestre Jou, 1982.

HEIDEGGER, Martin. Introdução à Metafísica. Tradução E. C. Leão. Rio de Janeiro: Tempo Brasileiro, 1969. 
HELBO, André (org.). Semiologia da representação - teatro, televisão, história em quadrinhos. São Paulo: Cultrix, 1980.

HOUAISS - Dicionário Eletrônico da Língua Portuguesa. Disponível em: http://forum.wordreference.com/showthread.php. Acessado em 05/10/2008.

HUIZINGA, Johan. Homo Ludens: O Jogo Como Elemento Da Cultura. Tradução João Paulo Monteiro. São Paulo: Perspectiva, 1971.

IANNONE, Leila Rentroia e IANNONE, Roberto Antônio. O mundo das histórias em quadrinhos. São Paulo: Moderna, 1994.

JACOMEL, Mirele Carolina Werneque. Uma leitura do processo de formação do cânone literário:o relativismo e a pretensão à universalidade. Travessias número 01, 2008. Disponível em www.unioeste.br/travessias. Acessado em 10/10/2008.

JAUS, Hans Robert et al. A Literatura e o leitor: textos de estética da recepção. Cação e tradução Luiz Costa Lima. Rio de Janeiro: Paz e Terra, 1979.

JESUALDO, J.S. A literatura infantil. (trad. James Amado). São Paulo: Cultrix/EDUSP, 1978.

KABOOM! O universo das HQs, Editora Eclipse, Ano 1, no. 1, 2005.

KAFKA, Franz. La Metamorfosis y otros relatos. Resúmenes, análisis y biografía Ernesto Livacic G. y Betty Rojas. Chile, Biblioteca de oro del estudiante, 1987.

KHÉDE, Sonia Salomão. Personagens da literatura infanto-juvenil. São Paulo: Editora Ática, 1986.

LAGO, Ângela. O códice, o livro de imagem para criança e as novas mídias. Disponível em: http://www.angela-lago.com.br/codice.html Acessado em 14/01/2008

LEONE, Eduardo e MOURÃO, Dora Maria. Cinema e montagem. São Paulo: Ed. Ática, 1993. 
LIMA, Luiz Costa. Teoria da Cultura de Massa. São Paulo: Paz e Terra, 1982.

LIMA, Yone Soares de. A ilustração na produção literária de São Paulo - década de vinte. São Paulo: IEB-USP, 1985.

LOTMAN, Iuri. A estrutura do texto artístico. Tradução Maria do Carmo Vieira Raposo e Alberto Raposo. Lisboa: Editorial Estampa, 1978.

LOPES, Ana Cristina; REIS, Carlos. Dicionário de Teoria da Narrativa. São Paulo: Editora Ática, 1988.

LUYTEN, Sônia Bibe (org.). Histórias em quadrinhos: leitura crítica. São Paulo: Paulinas, 1984.

Liberdade, 1991. Mangá - O poder dos quadrinhos japoneses. São Paulo:

LYOTARD, Jean-François. A Fenomenologia. (trad. Mary Amazonas leite de Barros). São Paulo: Difusão Européia do Livro, 1967.

MACHADO, Arlindo. A ilusão especular: introdução à fotografia. São Paulo: Brasiliense, 1984. . Novas tecnologias e liberdade (artigo não assinado). In Caderno Vida \& Arte. Fortaleza: Jornal O Povo, 20/10/2007. Disponível em: http://www.opovo.com.br/opovo/vidaearte/738494.html. Acessado em 12/2007.

MACHADO, Luis Toledo. Antonio de Alcântara Machado e o modernismo. Rio de Janeiro: José Olympio Editora,1970.

MARNY, Jacques. Sociologia das histórias aos quadradinhos. Porto: Livraria civilização, 1970.

MARTINS, J. Cândido. Teoria da paródia surrealista. Braga: 1995. 
MARTINS, Marcelo Machado. Narrativa policial: uma abordagem semiótica. 2000. Dissertação (Mestrado em Lingüística). Departamento de Lingüística, FFLCH, Universidade de São Paulo, São Paulo, 2000.

MATTOS, A. C. Gomes de. O outro lado da noite: filme noir. Rio de Janeiro: Rocco, 2001.

McCLOUD, Scott. Desvendando os quadrinhos. São Paulo: M. Books, 2002.

McLUHAN, Marshall. A galáxia de Gutenberg - a formação do homem tipográfico.

Tradução Leônidas Carvalho e Anísio Teixeira. São Paulo: CIA Editora Nacional, 1972.

MENDES, Maria dos Prazeres Santos. Monteiro Lobato, Clarice Lispector, Lygia Bojunga Nunes: o estético em diálogo na literatura infanto-juvenil. 1994. Tese (Doutorado em Comunicação e Semiótica). Programa de Comunicação e semiótica, PUC, São Paulo, 1994.

MELLO, Ana Maria Lisboa de. Humor e ironia na produção hipertextual de Oswald de Andrade: Pau-Brasil e Primeiro caderno do aluno de poesia. Ciênc. let., Porto Alegre, n.39, p.160-169, jan./jun. 2006. Disponível em:

http://www.fapa.com.br/cienciaseletras/publicacao.htm. Acessado em 05/10/2008.

MOISÉS, Leyla Perrone. Literatura Comparada, intertexto e antropofagia. In Flores da Escrivaninha. São Paulo: Companhia das Letras, 1990. . Texto, Crítica, Escritura. São Paulo: Ática, 1978.

MOISÉS, Massaud. Dicionário de termos literários. $7^{\mathrm{a}}$ edição. São Paulo: Cultrix, 1995. . A análise literária. 13 ${ }^{\mathrm{a}}$ edição. São Paulo: Cultrix, 1996.

MORIN, E. Ciência com consciência. Rio de Janeiro: Bertrand Brasil, 1998.

MOURALIS, Bernard. As contraliteraturas. Tradução Antonio F. R. Marques e João D. P. Correia. Coimbra: Livraria Almedina, 1982.

MOYA, Álvaro. et al. Literatura em quadrinhos no Brasil. São Paulo: Editora Nova 
Fronteira, 2002.

. História das histórias em quadrinhos. São Paulo: Brasiliense, 1994. . Shazam! São Paulo: Perspectiva, 1970.

NEIVA JR., Eduardo. A imagem. São Paulo: Ática, 1994.

NITRINI, Sandra. Literatura comparada: história, teoria e crítica. São Paulo: EDUSP, 2000.

NUNES, Lygia Bojunga. Reflexiones: Elogio al libro. HOJAS DE ACLIJ. Associacion Colombiana para el libro infantil y juvenil, serie 3, no 3, marzo de 1990.

ORLANDI, Eni P. Análise do Discurso - Princípios e Procedimentos. $3^{\mathrm{a}}$ ed. Campinas: Pontes, 2001.

PELLEGRINI, Tania et al. Literatura, cinema e televisão. São Paulo: Editora Senac/Instituto Itaú Cultural, 2003.

PIRES, Claudia. Antecedentes históricos da escrita. Disponível em: http://www.revista-temas.com/contacto/NewFiles/Contacto12.html Acessado em 07/01/2008.

PIVA, Luiz. Do antigo e do moderno na épica camoniana. Brasília: Clube de Poesia e Crítica, 1980.

QUELLA-GUYOT, Didier. A história em quadrinhos. São Paulo: Unimarco/Loyola, 1994.

REIS, Carlos e LOPES, Cristina M. Dicionário de narratologia. $2^{\mathrm{a}}$ edição. Coimbra, Almedina, 1990.

RENARD, Jean-Bruno A banda desenhada. Porto: Editorial Presença 1981.

RESENDE, Vânia Maria. O menino na Literatura Brasileira. São Paulo: Editora Perspectiva, 1988. 
ROMUALDO, Edson Carlos. Charge Jornalística: intertextualidade e polifonia. Maringá: Universidade Estadual de Maringá, 2000

ROSENFELD, Anatol; CANDIDO, Antonio; SALLES GOMES, Paulo Emílio. A personagem de fiç̧ão. São Paulo: Perspectiva, 1972.

ROSSI, P. A ciência e a filosofia dos modernos. São Paulo: Unesp, 1989.

SAID, Edward W. Cultura e imperialismo. São Paulo: Companhia das Letras, 1995.

SANTAELLA, Lucia. Imagem e cognição, semiótica, mídia. São Paulo: Iluminuras, 1998. Palavra, imagem \& enigmas. São Paulo: Revista USP, no. 16.

SANTOS, Ivete Irene dos. Fábula e intertextualidade: as figurativizações e as tematizações em versões de A galinha dos ovos de ouro. 2003. Dissertação (Mestrado em Comunicação e Letras). Departamento de Comunicação e Letras, Universidade Presbiteriana Mackenzie, São Paulo, 2003.

SEGOLIN, Fernando. Personagem e anti-personagem. São Paulo: Cortez \& Moraes, 1978.

SENDAK, Maurice. Entrevista In Boletim dos ilustradores. Rio de Janeiro: Fundação Nacional do Livro Infantil e Juvenil, Ano I, no.0, 1984.

SEVERINO, Antônio Joaquim. Metodologia do trabalho científico. São Paulo: Cortez, 2000.

SHAW, Harry. Dicionário de termos literários. Traduzido e adaptado por Cardigos dos Reis. Lisboa: Publicações Dom Quixote, 1978.

SILVA, Diamantino da. Quadrinhos para quadrados. Porto Alegre: Bells, 1976.

SILVA, Nadilson Manoel de. Fantasias e cotidiano nas histórias em quadrinhos. São Paulo: Annablume, 2002. 
SILVA, Vítor Manuel de Aguiar e. Teoria da literatura. Coimbra: Livraria Almedina, 1984. . Teoria e Metodologia Literárias. Lisboa: Universidade Aberta, 1990.

SILVA, Wally. Raízes das Histórias em quadrinhos. Disponível em: http://www.popbaloes.com/mats/hqnasala3.htm Acessado em 07/01/2008

SOARES, Mariza de Carvalho. A história vai ao cinema. Rio de Janeiro: Record, 2001.

SOLA, Ricardo; GÓRRIZ, Manuel; GÁLLEGO, Cándido Perez e DIETZ, Berend. Historia de la literatura inglesa I. Madrid: Taurus, 1988.

SOUSA, Rocha da. Ver etornar visível: formulações básicas em cinema e vídeo. Lisboa: Universidade Aberta, 1992.

SOUZA, Lélia Silveira Melo. O humor é coisa séria: tradução de tiras exemplificando com Frank e Ernest. 1997. Dissertação (Mestrado em Letras Modernas). Departamento de letras Modernas, FFLCH, Universidade de São Paulo, São Paulo, 1997.

TODOROV, T. Os gêneros do discurso. Tradução Elisa Angotti Kossovitch. São Paulo: Martins Fontes, 1980. 1971. . Poética da prosa. Tradução Maria de Santa Cruz. Lisboa: Edições 70, . The notion of literature, in New literary history. V, 1973, p.15-16.

UNIVERSIDADE DE SÃO PAULO. Sistema Integrado de Bibliotecas. Grupo DiTeses. Diretrizes para apresentação de dissertações e teses da usp: documento eletrônico e impresso. Vânia M. B. de Oliveira Funaro, coord. [et al]. São Paulo: SIBi-USP, 2004.

VERGUEIRO, Valdomiro. Histórias em quadrinhos: seu papel na indústria da comunicação de massa.1985. Dissertação (Mestrado em Comunicação) Escola de Comunicação e Artes, Universidade de São Paulo, São Paulo, 1985. et al. Como usar as histórias em quadrinhos em sala de aula. $3^{\mathrm{a}}$ edição. São Paulo: Contexto, 2006. Literatura brasileira em quadrinhos. 07/10/2005. Disponível 
em: http://www.poppycorn.com.br/artigo.php?tid=980 Acessado em janeiro de 2007. . As histórias em 10 quadrinhos. Disponível em:

http://omelete.locaweb.com.br/quadrinhos/artigos/base_para_artigos.asp?artigo=345. Acessado em 23/01/2006.

. Caminho das Pedras: A vida adulta das HQs. Especial para a Folha de S.Paulo, 26/10/2004. Disponível em:

http://www1.folha.uol.com.br/folha/sinapse/ult1063u952.shtml. Acessado em dezembro de 2006.

mais dinâmica. Disponível em:

http//:www.eca.usp.br/nucleos/njr/espiral/papiro20a.htm. Acessado em janeiro de 2007.

. Charles Clarence Beck e o Capitão Marvel. Disponível

em: http://www.omelete.com.br/quad/1000074.aspx Acessado em 07/01/2008 . As Histórias em Quadrinhos e seus gêneros - Parte 1. 2/5/2001. Artigo disponível no site: http://www.omelete.com.br/quadrinhos/artigos/. Acesso em 21 set. 2006

VERLEY, E. Colóquio sobre las palabrasy las cosas. In: Analisis de Michel Foucault. Buenos Aires: Tempo Contemporâneo, 1970.

XAVIER, Ismail. O discurso cinematográfico; a opacidade e a transparência. Rio de Janeiro, Paz e Terra, 1984.

. Alegorias do Subdesenvolvimento: Cinema Novo, Tropicalismo, Cinema Marginal. São Paulo: Brasiliense, 1993. (org.). A experiência do cinema. Rio de Janeiro: Graal, 1983.

WEBER, João Hernesto. Caminhos do romance brasileiro. Porto Alegre: Mercado Aberto, 1990. 


\section{OBRAS FICCIONAIS}

ANDERSEN, Hans Christian. Contos de Andersen. Tradução Guttorm Hanssen. Rio de Janeiro: Paz e Terra, 1981.

ASSIS, Machado et al. Missa do galo - variações sobre o mesmo tema. São Paulo: Summus, 1977.

BRAGA, Rubem (Org.). O livro de ouro dos contos russos. Rio de Janeiro: Ediouro, 2001.

CAMÕES, Luís de. Os Lusíadas. Apresentação: Carlos Felipe Moisés São Paulo: Editora Ática, 1998.

CAVALCANTI, Lailson de Holanda. Lusíadas 2500. São Paulo: Companhia Editora Nacional, 2006.

COUTINHO, Rafael et al. Branca de Neve. In "Irmãos Grimm em quadrinhos”. Rio de Janeiro: Desiderata, 2007.

FEVEREIRO, Jo. Gaetaninho. In "Contos de Antonio de A. Machado - série Literatura brasileira em quadrinhos”. São Paulo: Escala Educacional, 2006.

GALHARDO, Caco. Dom Quixote. Tradução Sérgio Molina. São Paulo: Peirópolis, 2005.

GAIMAN, Neil e VESS, Charles. Sandman no. 19, Terra dos sonhos - Sonho de Uma Noite de Verão. São Paulo: Editora Globo, 1991. e ZULLI. Sandman no. 14 - Casa de Bonecas - Homens de Boa Fortuna. São Paulo, Editora Globo, 1990. Graphica, 2002. et al. Livros da Magia. São Paulo: Editora Opera et al. Sandman no. 8, Prelúdios e noturnos: o som de suas asa. Tradução Marcelo de Castro Bastos. São Paulo: Brainstore, 2000. e McKEAN, Dave. Orquídea Negra. São Paulo: Opera Graphica, 2002.

GONSALES, Fernando. Níquel Náusea. Folha de São Paulo, 2002-2004. 
GRIMM, Jacob. Contos dos irmãos Grimm. Org. Dra. Clarissa Pinkola Estes. Rio de Janeiro: Rocco, 2005.

JABLONSKI, Carla. Os livros da magia - o convite. Tradução Ana Ban. São Paulo: Conrad, 2004.

LAMB, Charles \& Mary. Contos de Shakespeare. Tradução Mario Quintano. 2. ed. São Paulo: Globo, 1996.

MACEDO, Joaquim Manuel de. A Moreninha. 14 edição. São Paulo, Editora Ática, 1986.

MACHADO, Antonio de Alcântara. Gaetaninho.In “Brás, Bexiga e Barra Funda”. São Paulo, Imprensa Oficial do Estado,1983.

MALAPARTE, Curzio. Kaputt. Tradução Mário e Celestina da Silva. Rio de Janeiro: Civilização Brasileira, 1985.

MILLER, Frank e MAZZUCCHELLI, David. Grandes Clássicos DC 3: Batman Ano Um. Tradução Jotapê Martins e Helcio de Carvalho. São Paulo: Panini, 2005.

MIZUNO, Junko. Cinderalla. Tradução Drik Sada. São Paulo: Conrad, 2006.

MONTEIRO, Gutemberg. A Moreninha (quadrinização). Rio de Janeiro: EBAL, 1952.

MUTARELLI, Lourenço. O dobro de 5. São Paulo: Devir, 1999.

ORDWAY, Jerry e KRAUSE, Peter. Shazam $n^{\circ} 0$. São Paulo, DC Comics/Abril Jovem, 1995. 1995/1997. . Shazam no. 8. São Paulo, DC Comics/Abril jovem,

PINTO, Ziraldo Alves. Todo Pererê. São Paulo: Moderna, 2002. O Menino Quadradinho. São Paulo: Melhoramentos, 1989. 
RIOS, Rosana e DELPHIM, Getulio (il.). Confronto Mortal - o mundo dos HQs. São Paulo: Moderna, 1997.

SHAKESPEARE, William. A Tempestade. Tradução Beatriz Viégas-Faria. Porto Alegre: L\&PM, 2002.

Porto Alegre: L\&PM, 2002. . Sonho de uma noite de verão. Tradução Beatriz Viégas-Faria.

SCLIAR, Moacyr. Shazam. In Contos Reunidos. São Paulo: Companhia das Letras, 1995.

SPACCA. O patinho feio. São Paulo: Revista Níquel Náusea, ano I, n ${ }^{\circ}$ 2, p. 25-28.

VASQUES, Edgar et al. Pega pra kapput. Porto Alegre: L\&PM, 1978.

VERÍSSIMO, Luis Fernando; PAIVA, Miguel (il.). Ed Mort,em procurando o Silva. Porto Alegre: L\&PM, 1991. 


\section{ÍNDICE DE FIGURAS}

Fig. 1- Pág. 17. Imagem da Caverna de LASCAUX, França. Reproduzida do site http://www.artchive.com/ftp_site.htm

Fig. 2 - Pág. 18. Imagem do Parque Nacional da Serra da Capivara, Piauí. FUNDHAMFundação Museu do Homem Americano. Reproduzida do site www.fumdham.org.br/fotos/pintura01.jpg

Fig. 3- Pág. 20. Imagem da Tábua de Narmer (Museu do Cairo, Egito). Reproduzida do site: www.art-and-archaeology.com/timelines/egypt/linkimages/narmer2.jpg

Fig. 4- Pág. 23. Imagem da BibliaPauperum - blockbook, Schreiber III - Reproduzida do site: www.content.cdlib.org/.../ft7v19p1w6_00079.gif

Fig 5- Pág. 28. Filho e filha oferecem buquet de Amon ao morto. DAVIES, Norman de Garis. Two Ramesside Tombs at Thebes, New York: The Metropolitan Museum of Art, 1927. (Tytus Memorial Series, V. Reproduzida do site:

www.fanreal.com/tese/gal.html

Fig. 6- Pág. 29. Trecho da obra Histoires en Estampes de Topffer. Reproduzida do site: www.fanofunny.com/topffer.gif

Fig. 7- Pág. 32. Ilustração de As Aventuras de Nhô-Quim \& Zé Caipora: os primeiros quadrinhos brasileiros 1869-1883. Pesquisa, organização e introdução de Athos Eicler Cardoso. Brasília: Senado Federal, Conselho Editorial, 2002. Reproduzida do site: www.universohq.com/quadrinhos/especial_agostini.cfm

Fig. 8- Pág. 33. Capa do livro, A turma do Perere: as manias do Tininim de Ziraldo. São Paulo: Editora Globo, 2007. Reprodução

Fig.9 - Pág. 49. Seqüência da HQ Dom Quixote, desenhada por Caco Galhardo. Tradução Sérgio Molina. São Paulo: Peirópolis, 2005. pág.13 - Reprodução. 
Fig. 10 - Pág. 49. Seqüência da HQ Grandes Clássicos DC 3: Batman Ano Um, de Frank Miller e David Mazzucchelli. São Paulo: Panini, 2005, pág. 82 - Reprodução.

Fig. 11- Pág. 51. Seqüência da HQ Sandman no. 8, Prelúdios e noturnos: o som de suas asa., de Neil Gaiman et al. São Paulo: Brainstore, 2000, pág.20 - Reprodução.

Fig. 12 - Pág. 52. Ilustrações do livro Narrativas Gráficas de Will Eisner. Tradução Leandro Luigi Del Manto. São Paulo: Devir, 2005, pág. 23 - Reprodução.

Fig. 13- Pág. 54. Seqüência da HQ Ed Mort de Luis Fernando Veríssimo e Miguel Paiva. Porto Alegre: L\&PM, 1991, pág. 04 - Reprodução.

Fig. 14- Pág. 55. Seqüência da HQ Ed Mort de Luis Fernando Veríssimo e Miguel Paiva. Porto Alegre: L\&PM, 1991, pág.11 - Reprodução.

Fig. 15 - Pág. 56. Seqüência da HQ O Dobro do Cinco, de Mutarelli. São Paulo: Devir, 1999, pág.97 - Reprodução.

Fig. 16 - Pág. 57. Seqüência retirada da HQ Orquídea Negra, de Neil Gaiman e Dave McKean. São Paulo: Opera Graphica, 2002, pág.13 - Reprodução.

Fig. 17 - Pág. 58. Seqüência do livro O menino quadradinho de Ziraldo. São Paulo: Melhoramentos, 1989, pág.12 - Reprodução.

Fig 18 - Pág. 59. Seqüência da HQ Orquídea Negra, de Neil Gaiman e Dave McKean. São Paulo: Opera Graphica, 2002, pág.27 - Reprodução.

Fig 19 - Pág. 60. Seqüência do livro Todo Pererê de Ziraldo. São Paulo: Moderna, 2002, pág.19 - Reprodução.

Figs 20 e 21 - Pág. 60. Seqüência da HQ Grandes Clássicos DC 3: Batman Ano Um, de Frank Miller e David Mazzucchelli. São Paulo: Panini, 2005, págs.121 e 122 Reprodução.

Fig. 22 - Pág. 63. Adaptação do Fantasma de Canterville feita por Nelson Rodrigues e Alceu Pena, in A Guerra dos Gibis: a formação do mercado editorial brasileiro e a 
censura dos quadrinhos, 1933-64. São Paulo: Companhia das Letras, 2004, pág.64 Reprodução.

Fig. 23 - Pág. 79. Seqüência da HQ A Moreninha, desenhada por Monteiro Gutemberg. Rio de Janeiro: EBAL, 1952, pág.5 - Reprodução.

Fig. 24 e 25- Pág. 80. Seqüência da HQ A Moreninha, desenhada por Monteiro Gutemberg. Rio de Janeiro: EBAL, 1952, págs.12 e 13 - Reprodução.

Fig. 26 - Pág. 82. Seqüência da HQ A Moreninha, desenhada por Monteiro Gutemberg. Rio de Janeiro: EBAL, 1952, pág.18 - Reprodução.

Fig. 27 - Pág. 83. Seqüência da HQ A Moreninha, desenhada por Monteiro Gutemberg. Rio de Janeiro: EBAL, 1952, pág.36 - Reprodução.

Fig. 28 - Pág. 84. Seqüência da HQ A Moreninha, desenhada por Monteiro Gutemberg. Rio de Janeiro: EBAL, 1952, págs. 24, 28 e 29 - Reprodução.

Fig. 29 - Pág. 85. Seqüência da HQ A Moreninha, desenhada por Monteiro Gutemberg. Rio de Janeiro: EBAL, 1952, pág.30 - Reprodução.

Fig. 30 - Pág. 86. Seqüência da HQ A Moreninha, desenhada por Monteiro Gutemberg. Rio de Janeiro: EBAL, 1952, pág.28 - Reprodução.

Fig. 31 - Pág. 87. Seqüência da HQ Cinderalla, de Junko Mizuno. São Paulo: Conrad, 2006, págs.128 e 129 - Reprodução.

Fig. 32. Pág. 92. Seqüência da HQ Contos de Antonio de A. Machado - série Literatura brasileira em quadrinhos, desenhada por Jô Fevereiro. São Paulo: Escala Educacional, 2006, pág.3 - Reprodução.

Fig. 33 -Pág. 93. Seqüência da HQ Contos de Antonio de A. Machado - série Literatura brasileira em quadrinhos, desenhada por Jô Fevereiro. São Paulo: Escala Educacional, 2006, pág.4 - Reprodução. 
Fig. 34 - Pág. 95. Seqüência da HQ Contos de Antonio de A. Machado - série Literatura brasileira em quadrinhos, desenhada por Jô Fevereiro. São Paulo: Escala Educacional, 2006, pág.7- Reprodução.

Fig. 35 e 36 - Pág. 96. Seqüência da HQ Contos de Antonio de A. Machado - série Literatura brasileira em quadrinhos, desenhada por Jô Fevereiro. São Paulo: Escala Educacional, 2006, págs.11 e 13 - Reprodução.

Fig. 37- Pág. 101. Seqüência do livro Lusíadas 2500, desenhada por Lailson de Holanda Cavalcanti. São Paulo: Companhia Editora Nacional, 2006, pág.7 - Reprodução.

Fig. 38 - Pág. 103. Seqüência do livro Lusíadas 2500, desenhada por Lailson de Holanda Cavalcanti. São Paulo: Companhia Editora Nacional, 2006, pág.25 - Reprodução.

Fig 39 - Pág. 104. Seqüência do livro Lusíadas 2500, desenhada por Lailson de Holanda Cavalcanti. São Paulo: Companhia Editora Nacional, 2006, pág.76 - Reprodução.

Fig 40 - Pág. 105. Seqüência do livro Lusíadas 2500, desenhada por Lailson de Holanda Cavalcanti. São Paulo: Companhia Editora Nacional, 2006, pág.96 - Reprodução.

Fig. 41 - Pág. 106. Seqüência do livro Lusíadas 2500, desenhada por Lailson de Holanda Cavalcanti. São Paulo: Companhia Editora Nacional, 2006, pág.99 - Reprodução.

Fig. 42 - Pág. 109. Seqüência da HQ Branca de Neve, desenhada por Rafael Coutinho. In Irmãos Grimm em quadrinhos. Rio de Janeiro: Desiderata, 2007, pág.89 - Reprodução.

Fig. 43 - Pág. 111. Seqüência da HQ Branca de Neve, desenhada por Rafael Coutinho. In Irmãos Grimm em quadrinhos. Rio de Janeiro: Desiderata, 2007, pág.90 - Reprodução.

Fig. 44 - Pág. 112. Seqüência da HQ Branca de Neve, desenhada por Rafael Coutinho. In Irmãos Grimm em quadrinhos. Rio de Janeiro: Desiderata, 2007, pág.90 - Reprodução.

Fig. 45 - Pág. 113. Seqüência da HQ Branca de Neve, desenhada por Rafael Coutinho. In Irmãos Grimm em quadrinhos. Rio de Janeiro: Desiderata, 2007, págs. 91, 94 e 96 Reprodução. 
Fig. 46 - Pág. 114. Seqüência da HQ Branca de Neve, desenhada por Rafael Coutinho. In Irmãos Grimm em quadrinhos. Rio de Janeiro: Desiderata, 2007, pág.91 - Reprodução.

Fig. 47 - Pág. 115. Seqüência da HQ Branca de Neve, desenhada por Rafael Coutinho. In Irmãos Grimm em quadrinhos. Rio de Janeiro: Desiderata, 2007, pág.99 - Reprodução.

Fig. 48 - Pág. 116. Seqüência da HQ Branca de Neve, desenhada por Rafael Coutinho. In Irmãos Grimm em quadrinhos. Rio de Janeiro: Desiderata, 2007, pág.99 - Reprodução.

Fig. 49 - Pág. 120. Seqüência da HQ Patinho Feio de Spacca. São Paulo: Revista Níquel Náusea, ano I, n ${ }^{\circ}$ 2, pág. 25 - Reprodução.

Fig. 50 - Pág. 121. Seqüência da HQ Patinho Feio de Spacca. São Paulo: Revista Níquel Náusea, ano I, n ${ }^{\circ}$ 2, pág. 26 - Reprodução.

Fig. 51 - Pág. 122. Seqüência da HQ Patinho Feio de Spacca. São Paulo: Revista Níquel Náusea, ano I, n ${ }^{\circ}$ 2, pág. 27 - Reprodução.

Fig 52 - Pág. 123. Seqüência da HQ Patinho Feio de Spacca. São Paulo: Revista Níquel Náusea, ano I, n ${ }^{\circ}$ 2, pág. 28 - Reprodução.

Fig 53 - Pág. 124. Seqüência da HQ Patinho Feio de Spacca. São Paulo: Revista Níquel Náusea, ano I, n ${ }^{\circ}$ 2, pág.28 - Reprodução.

Fig. 54 - Pág. 126. Tira de Níquel Náusea de Fernando Gonsales. Folha de São Paulo, 2002-2004. Gentilmente cedida por Fernando Gonsales.

Fig. 55 - p.127. Tira de Níquel Náusea de Fernando Gonsales. Folha de São Paulo, 20022004. Gentilmente cedida por Fernando Gonsales.

Fig. 56 - Pág. 128. Tira de Níquel Náusea de Fernando Gonsales. Folha de São Paulo, 2002-2004. Gentilmente cedida por Fernando Gonsales. 
Fig. 57 - Pág. 129. Tira de Níquel Náusea de Fernando Gonsales. Folha de São Paulo, 2002-2004. Gentilmente cedida por Fernando Gonsales.

Fig. 58 - Pág. 130. Tira de Níquel Náusea de Fernando Gonsales. Folha de São Paulo, 2002-2004. Gentilmente cedida por Fernando Gonsales.

Fig. 59 - Pág. 134. Seqüência da HQ . Sandman no. 14 - Casa de Bonecas - Homens de Boa Fortuna, de Neil Gaiman e Zulli. São Paulo: Editora Globo, 1991, pág.13 Reprodução.

Fig. 60 - Pág. 136. Seqüência da HQ . Sandman no. 19, Terra dos sonhos - Sonho de Uma Noite de Verão, de Neil Gaiman e Charles Vess. São Paulo: Editora Globo, 1991, pág.2 Reprodução.

Fig. 61 - Pág. 137. Seqüência da HQ . Sandman no. 19, Terra dos sonhos - Sonho de Uma Noite de Verão, de Neil Gaiman e Charles Vess. São Paulo: Editora Globo, 1991, pág.7 Reprodução.

Fig. 62 - Pág. 138. Seqüência da HQ . Sandman no. 19, Terra dos sonhos - Sonho de Uma Noite de Verão, de Neil Gaiman e Charles Vess. São Paulo: Editora Globo, 1991, pág.13 Reprodução.

Fig. 63 - Pág. 139. Seqüência da HQ . Sandman no. 19, Terra dos sonhos - Sonho de Uma Noite de Verão, de Neil Gaiman e Charles Vess. São Paulo: Editora Globo, 1991, pág.21 Reprodução.

Fig. 64 - Pág. 141. Seqüência da HQ Sandman no. 19, Terra dos sonhos - Sonho de Uma Noite de Verão, de Neil Gaiman e Charles Vess. São Paulo: Editora Globo, 1991, pág.23 Reprodução.

Fig. 65 - Pág. 149. Shazam, nº 0, Publicado em: outubro de 1996 pela Editora Abril, licenciado pela DC Comics. Reproduzido do site:

http://www.guiadosquadrinhos.com/edicao.aspx?cod_tit=shz0301+\&esp=\&cod_edc=7634

Fig. 66 - Pág. 150. Shazam. Cena de Whiz Comics 1 -1940. Reproduzido do site:

Cena de Whiz Comics 1 (1940) em que Billy transforma-se, pela primeira vez, no Capitão Marvel. Reproduzida do site: http://www.omelete.com.br/quad/1000074.aspx 
Fig. 67 e 68 - Pág. 154. Seqüência da HQ Shazam nº8, de Jerry Ordway e Peter Krause. São Paulo: DC Comics/Abril Jovem, 1995, págs 22 e 26 - Reprodução.

Fig. 69 - Pág. 157. Seqüência da HQ Livros da Magia de Neil Gaiman e John Bolton. São Paulo: Editora Opera Graphica, 2002, pág.13 - Reprodução.

Fig. 70 - Pág. 158. Seqüência da HQ Livros da Magia de Neil Gaiman e Charles Vess. São Paulo: Editora Opera Graphica, 2002, pág.7 - Reprodução.

Fig. 71 - Pág. 160. Seqüência da HQ Livros da Magia de Neil Gaiman e Paul Johnson. São Paulo: Editora Opera Graphica, 2002, pág.44 - Reprodução.

Fig. 72 - Pág. 165. Seqüência do livro Confronto Mortal - o mundo dos HQs. de Rosana Rios e Getulio Delphim (il.). São Paulo: Moderna, 1997, pág.13 - Reprodução.

Fig. 73 - Pág. 166. Seqüência do livro Confronto Mortal - o mundo dos HQs. de Rosana Rios e Getulio Delphim (il.). São Paulo: Moderna, 1997, pág.72 - Reprodução.

Fig. 74 - Pág. 168. Seqüência do livro Confronto Mortal - o mundo dos HQs. de Rosana Rios e Getulio Delphim (il.). São Paulo: Moderna, 1997, pág.79 - Reprodução.

Fig. 75 - Pág. 171. Seqüência do livro Pega pra kaput de Edgar Vasques et al. Porto Alegre: L\&PM, 1978, pág.21 - Reprodução.

Fig. 76 - Pág. 172. Seqüência do livro Pega pra kaput de Edgar Vasques et al. Porto Alegre: L\&PM, 1978, pág.22 - Reprodução.

Fig. 77 - Pág. 174. Seqüência do livro Pega pra kaput de Edgar Vasques et al. Porto Alegre: L\&PM, 1978, pág.54 - Reprodução.

Fig. 78 - Pág. 176. Seqüência do livro Pega pra kapput de Edgar Vasques et al. Porto Alegre: L\&PM, 1978, pág.121 - Reprodução. 